\title{
"A Debt of Honor": Elite Women's Rituals of Cultural Authority in the Confederate Capital
}

\author{
Ashley Whitehead Luskey
}

Follow this and additional works at: https://researchrepository.wvu.edu/etd

\section{Recommended Citation}

Luskey, Ashley Whitehead, "'A Debt of Honor": Elite Women's Rituals of Cultural Authority in the Confederate Capital" (2014). Graduate Theses, Dissertations, and Problem Reports. 6124.

https://researchrepository.wvu.edu/etd/6124

This Dissertation is protected by copyright and/or related rights. It has been brought to you by the The Research Repository @ WVU with permission from the rights-holder(s). You are free to use this Dissertation in any way that is permitted by the copyright and related rights legislation that applies to your use. For other uses you must obtain permission from the rights-holder(s) directly, unless additional rights are indicated by a Creative Commons license in the record and/ or on the work itself. This Dissertation has been accepted for inclusion in WVU Graduate Theses, Dissertations, and Problem Reports collection by an authorized administrator of The Research Repository @ WVU.

For more information, please contact researchrepository@mail.wvu.edu. 


\title{
“A Debt of Honor":
}

\section{Elite Women's Rituals of Cultural Authority in the Confederate Capital}

\author{
Ashley Whitehead Luskey \\ Dissertation submitted \\ to the Eberly College of Arts \& Sciences \\ at West Virginia University \\ in partial fulfillment of the requirements of the degree of \\ Doctor of Philosophy in \\ History
}

\begin{abstract}
Jason Phillips, Ph.D., Chair
Peter Carmichael, Ph.D.

Aaron Sheehan-Dean, Ph.D.

Krystal Frazier, Ph.D.

Elizabeth Fones-Wolf, Ph.D.
\end{abstract}

Department of History

Morgantown, West Virginia

2014

Keywords: Civil War, Confederacy, southern women, ritual, social order, culture, class, gender, power, Richmond, Virginia 


\section{ABSTRACT \\ "A Debt of Honor": Elite Women's Rituals of Cultural Authority in the Confederate Capital}

\section{Ashley Whitehead Luskey}

This dissertation analyzes the carefully crafted cultural rituals and social interactions of elite women in Richmond, Virginia in order to understand how those women sought to reaffirm their contested claims to ladyship and impose "proper" social and moral order over an increasingly disordered Confederate capital during the Civil War. As the capital of the Confederacy, Richmond stood for four years as the heart and heartbeat of the Confederate nation and thus as a conspicuous model for southern society. Throughout those four years, Richmond found itself continuously barraged by an influx of soldiers, refugees, prostitutes, scam artists, impoverished soldiers' wives, and both free and enslaved African-Americans who sought shelter, employment, self-betterment, and mere survival. However, with this influx came a rise in vice, crime, and dangerous social unrest. Through forceful projections of their unique class and gender identity, and through both direct and symbolic negotiations with their subordinates and peers for power during house visits, exclusive parlor parties, promenades, theater-going, presidential receptions, "starvation parties," and holiday celebrations, Richmond's "capital elite" (the wives and daughters of politicians, generals, and wealthy civic leaders) sought to reaffirm their threatened cultural authority and stabilize the city's precarious social order during four years of civil war and unprecedented social unrest.

Such rituals provide a fascinating lens into the evolving worldviews, social perceptions, and self-consciousness of the leading ladies of the Confederate capital. In several instances, some of those perceptions of self and social responsibility resulted in charitable aid and patriotic acts that contributed to the physical and emotional health of the Confederacy in valuable ways. Such was especially true during the early part of the war, when the ladies maintained a strong presence in both public and private social settings. However, in other instances, certain worldviews created mental blind spots that prevented the ladies from fully understanding the needs and frustrations of their subordinates. Those blind spots frequently resulted in behavior that ultimately alienated many of the ladies from the very individuals whose deference they so desperately sought to gain. Such alienation, combined with the numerous and mounting stresses that the war continued to place on the civilian population, sewed additional seeds of social unrest and disaffection for the ruling class amongst the public masses. Thus, over the course of the war, the ladies turned increasingly inward and began to place a greater emphasis on more intimate and exclusive social rituals. However, despite such reverses, the leading ladies continued to cling to their rituals with a remarkable perseverance and tenacity of purpose until the very end of the war (and some, even beyond that time), revealing the cherished, influential, and foundation role that such rituals played in the minds, lives, and identities of the female capital elite.

Generally speaking, this valuable portal into these women's minds reveals how individuals have relied on unofficial and often informal social interactions as rituals through which they have sought both to reaffirm their own contested power and to affect broader social change upon society as a whole. Specifically, it brings us ever closer to understanding the complexities of gender roles in the Civil War South, the evolving mental frameworks that governed the lives and actions of this influential group of female actors, the changing power 
dynamics that shaped social relationships and the functioning of the Confederate capital, and the leading ladies' responses to both the civil and civic wars that engulfed society and transformed their lives from 1861-1865. 


\section{Table of Contents}

Introduction: Richmond and Ritual in the Civil War Era ....... 1

Richmond Reborn: A Brief Overview of the Capital City in Transition

Chapter 1- Keeping up Appearances: House Visits and the Establishment of

Richmond's Capital Elite ........ 28

Chapter 2- The Unbearable Heaviness of Being: Elite Parties, the Defense of

Ladyship, and the Maintenance of Morale in the Confederate Capital..........

Chapter 3- Performing Ladyship, Sorting Society: The Promenade, Public Receptions, and Theater-Going ......... 120

Chapter 4- "To Whom Much is Given, Much is to be Required": Ladies' Charity in Confederate Richmond 172

Chapter 5- The Perils of Compassion: Public Disaffection and the Championing of Personal Charity.......... 218

Chapter 6- "They Came to the Rescue as They Had Often Done Before": Holiday Ritual and the "Last Confederate Christmas of 1864"....... 255

Conclusion- "Pleading for Greater Light": Women and the Written Reconstruction of Richmond in the Postwar Era ......... 304

Bibliography ......... 319 


\section{Acknowledgments}

The roots of this dissertation extend back nearly ten years to a History class taught by Professor James Whittenburg that I took during my sophomore year of college at the College of William \& Mary. I still remember the exact moment when I began to fall in love with this topic, while standing in the bedroom of Varina Davis during a tour of the White House of the Confederacy, in Richmond, Virginia on a class trip to the former Confederate capital. Utterly fascinated by Varina's complexities and contradictions as a leading lady of Richmond, I knew immediately that I had to pursue a study of the "inner world" of Varina Davis, and I excitedly set out to discern the exact nature of society's expectations of her as the Confederacy's First Lady. This intrigue ultimately led to a senior honor's thesis on the topic, directed by Professor Whittenburg. As is true for many of my personal and professional pursuits thus far in the field of History, I am indebted to Dr. Whittenburg for his help and inspiration, and for leading me to the genesis of this project. I am eternally grateful for the undying support, encouragement, advice, and the friendship of both him and his wonderful wife, Dr. Carolyn Whittenburg, who have been like second parents to me ever since I first set foot on the campus of William and Mary.

As I continued through graduate school at West Virginia University, my research on Varina Davis matured and expanded into the larger project that has become the focus of my dissertation. This dissertation could not have been written without the fabulous education and continuous intellectual challenge that I received from my many amazing professors in the History department at West Virginia University, especially Dr. Peter Carmichael, Dr. Brian Luskey, Dr. Aaron Sheehan-Dean, as well as Dr. John Ernest from the English department. I am also incredibly grateful for the enormous support and helpful critique of my additional committee members, Dr. Jason Phillips, Dr. Kimberly Welch, and Dr. Krystal Frazier who have 
been a tremendous help in shaping this project and providing me with the inspiration and encouragement to keep forging on during some of the most challenging days of researching, writing, and revising. Due to a series of unexpected events, the make-up of my committee has changed a remarkable four times since its creation in 2013. My current committee has been wonderful in adapting to those changes and in helping to make the transition between committees as smooth as possible. I want to thank Aaron and Jason, particularly, for graciously stepping in (at different times) to serve as chair of my committee immediately upon their arrivals at WVU, and also Aaron and Pete for choosing to continue to serve on my committee even after their transferal to other universities. I am also grateful to Elizabeth Fones-Wolf for kindly agreeing to serve as a last-minute, additional defense-day committee member in order to ensure that I would have the required number of in-room committee members present for a summer defense.

I also would like to extend many thanks to my colleagues and closest friends from West Virginia University, especially Elizabeth Dietzen, William Feeney, Katherine Brackett Fialka, as well as Joel Christenson, for their enormous support and encouragement through the most trying days of graduate school and for their wisdom, thoughtful input, inspiration, and witty banter that has kept me going throughout this process. Thank you also to Dr. William Blair for his generous advice and input on my research during various academic conferences that I attended as a graduate student at WVU these past few years.

I have numerous, additional individuals to thank for their help during the dissertation process itself. Many, many thanks to Frances Pollard, Catherine Wilkins, and the fantastic staff at the Virginia Historical Society who made my many long days of research there so much more enjoyable and productive. Thank you also to the wonderful staff at the Library of Virginia, the 
Southern Historical Collection at the University of North Carolina at Chapel Hill, the David M. Rubenstein Rare Book \& Manuscript Library at Duke University, the Albert and Shirley Small Special Collections Library, the Library of Virginia, and the Library of Congress for all of their help and consultation during the research phase.

I would also like to extend a very special thanks to Dr. John Coski at the Museum of the Confederacy for his generosity in donating so much of his time to advising me on my research, pulling special documents for me that I otherwise would not have seen, and helping to shape the ways in which I have approached this topic. Thank you also to Teresa Roane of the Eleanor S. Brockembrough Library at the Museum of the Confederacy for her help and counsel during my research days at the MOC.

I certainly could not have finished this dissertation without the support of my supervisors and colleagues at Richmond National Battlefield Park for allowing me two, very generous sixmonth sabbaticals to research and write, and for graciously assuming my share of work at the Park during my absence. Thank you also to my friend and colleague, Michael D. Gorman for his willingness to share his font of knowledge on Civil War Richmond with me and for the numerous citations and tidbits of evidence he has sent me these past couple of years that have helped immensely to enrich my project. Additionally, many thanks to Richmond National Battlefield Park historian, Robert E. L. Krick for the many informative discussions about life in Civil War Richmond and for various source material for my project, as well as for selflessly dropping everything upon my entrance into in his office to assist in hammering out tiny details for my project, no matter how long and frustrating the process could be at times!

Numerous friends and colleagues in the History field have also contributed significantly to this project over the years by sending numerous bits of research and citations to me, even 
while they were in the archives doing research for their own projects. I am especially grateful to my good friends, Bert Dunkerly of Richmond National Battlefield Park, Emmanuel Dabney of Petersburg National Battlefield, J. Michael Moore, and Dr. Brian Matthew Jordan for their help, encouragement, and advice throughout the dissertation process and for the enriching and intellectually stimulating conversations that helped me conceptualize my topic. I am also grateful to all of them for introducing me to new research methodologies, venues, archival staff, and fellow colleagues that have helped with the completion of this dissertation. I would also like to thank John Hennessy, Chief of Interpretation at Fredericksburg and Spotsylvania National Military Park, for the many citations, diary transcripts, and newspaper transcripts he kindly sent me throughout the research and writing phase.

To my amazing friends, especially Katherine Reilly, Catherine Alford, Katherine Brackett Fialka, Bert Dunkerly, Elizabeth Dietzen, Alexandra LaMela, Mary Catherine French, and Allison Jordan, thank you so very much for being some of the best friends an historian could have! Your love, support, advice, humor, and inspiration have helped me and my project more than you will ever know.

To my incredible family, I truly don't think I could have made it through graduate school, let alone writing a dissertation, without your undying love, encouragement, inspiration, and comfort. You introduced me to the joys and wonders of History in childhood, supported me in my development as a junior scholar through adolescence, and have continued to inspire me to pursue my dreams and a career in History through some of the most difficult times of my life. To both my immediate family and my wonderful in-laws, I love you all so much and can never thank you enough for helping me reach this point in my academic career. 
To Dr. Peter Carmichael, I can never express just how much you have shaped my life, both personally and professionally. Thank you a thousand times over for taking me under your wing at WVU and for providing me with some of the most amazing opportunities of a lifetime. You have been an inspiration to me throughout graduate school, a tremendous friend, and a dedicated mentor whose brilliance, wit, and character are truly larger than life. Thank you for the constant intellectual challenge and for always pushing me to be the best historian I can be. You have introduced me to ways of thinking that have broadened and enriched my life tenfold. Thank you for everything. Thank you also to Beth Carmichael for your constant love and support these past several years. You and Pete have also been true second parents to me, and I can never thank you enough for all that you have done for me.

And finally, to my wonderful, brilliant, and loving husband, Brian Luskey-from mentor to life partner, you have filled my life with so much more meaning and love than I ever could have imagined. You are an inspiration to me in every aspect of life, from helping me to become the best historian possible, to inspiring me to become the best possible person I can be. I have never met a kinder, more sincere, or more dedicated person than you. Thank you so very much for supporting me, for being my "soundboard" of ideas, for being tremendously patient with me, for never failing to make me laugh, and for being my partner through all of life's adventures, both good and bad; but most of all, thank you for loving me unconditionally.

From the bottom of my heart, I thank you all! 



\section{Introduction-- Richmond and Ritual in the Civil War Era}

On April 18, 1861, just one day after the Virginia secession convention voted to secede from the Union, a Richmond girl wrote excitedly in her diary, “Oh! Joyful and ever to be remembered day, Virginia has seceded from the abolition government!"1 As regiment after regiment of newly recruited soldiers filed into the city to the celebratory music of the Armory Band, Richmonders flocked to the streets and packed themselves into the grounds of the State Capitol to partake in the elaborate display of fireworks, the fiery speeches of local politicians, and the momentous raising of the Confederate flag above the statehouse. Wild with excitement, many of the city's residents basked in the glow of their "patriotic revolution" and indulged in visions of an assured victory in the fledgling Confederacy's war against the Union. Their excitement only intensified with the transfer of the Confederate capital from Montgomery, Alabama to Richmond on May 29, 1861. Richmond ladies, bedecked in their finest dresses and bonnets, lined the streets leading to Capitol Square, waving handkerchiefs and throwing bouquets of flowers at the carriage of the newly appointed President of the Confederacy, Jefferson Davis, as it wended its way to Davis's temporary home at the Spotswood Hotel, on the corner of $8^{\text {th }}$ and Main Streets. The grandiose celebrations, parties, dinners, and spirited rallies that followed seemed to promise only good things for the people of the Confederacy's new capital city. $^{2}$

However, as train cars and wagons filled with thousands of politicians, soldiers, refugees, prostitutes, dangerous "confidence men," and speculators poured into Richmond, numerous

\footnotetext{
1 Unknown author, Diary of a Richmond girl, April 18, 1861, qtd. in Ernest B. Furgurson, Ashes of Glory: Richmond at War (New York: Random House, Inc., 1996), 37.

2 Furgurson, 54; Sallie Brock Putnam, Richmond During the War: Four Years of Personal Observation (New York: G.W. Carleton, 1867, reprint; Lincoln: University of Nebraska Press, 1996), 27.
} 
residents, and especially the former leading ladies of the city, quickly began to question the social repercussions of the capital's transfer to Richmond. One resident remarked with disgust that "all the loose population along the railroad...seemed to have clung to and been pulled into Richmond with it," while, during the fall of 1861, the concerned editors of the Richmond Examiner condemned the city as a "bloated metropolis of vice." 3 As a staunchly traditional and socially insular community of 38,000 , Richmonders eyed the new arrivals with intense suspicion and, in the words of Confederate First Lady Varina Davis, "a certain offishness...they seemed to feel that an inundation of people perhaps of doubtful standards, and, at best, of different methods, had poured over the city, and they reserved their judgment and confidence."

Realizing the threats that this influx of strangers to the city would pose to their own social status and authority, as well as to the traditional social and moral order of society at large, Richmond's ladies responded to this invasion through a variety of social rituals through which, they believed, they might defend their claims to ladyship and reinstitute order in their beloved city. Constantly in negotiation for authority with incoming refugees of the elite class, with the thousands of poor white women, soldiers' wives, slaves, and free African Americans, and with their numerous male critics, the leading ladies of Richmond were forced continuously to adapt their social interactions to the evolving challenges that the Civil War placed upon Richmond society.

This dissertation examines how they did so. Doubtless, other, major urban hubs in the Confederacy such as Atlanta, New Orleans, and Charleston possessed their own, unique societies with their own respective social tensions and wartime challenges to which they responded in

\footnotetext{
${ }^{3}$ Qtd. in Emory Thomas, The Confederate State of Richmond: A Biography of the Capital (Baton Rouge: Louisiana State University Press, 1998), 65-69; see also, Varina Davis, Jefferson Davis, ex-president of the Confederate States of America; a memoir written by his wife (New York: Belford Company, 1890), 202-3.

4 Qtd. in Fergurson, 54; for a full study on what generally classified women as "deviant" during the antebellum and Civil War eras, and why these women posed such a threat to society, see, Victoria E. Bynum, Unruly Women: The Politics of Social and Sexual Control in the Old South (Chapel Hill: The University of North Carolina Press, 1992).
} 
their own way. However, as the Confederate capital, Richmond stood for four years as the heart and heartbeat of the Confederate nation and thus a conspicuous model for southern society that is worth studying. This project analyzes the social and cultural rituals of Richmond's female elite as a valuable portal into these women's minds. Generally speaking, this portal reveals how individuals, throughout history, have relied on a variety of unofficial and, often, informal social interactions as a means through which they have tried both to reaffirm their own contested identities and to affect broader social change upon society as a whole. Specifically, such a window into these women's minds brings us ever closer to understanding the evolving mental frameworks that governed the lives and actions of this influential group of female actors, the changing power dynamics that shaped social relationships and the functioning of the Confederate capital, and the inner world of the "capital elite."

Through house visits, parlor parties, promenades, theater-going, public receptions, "starvation parties," and holiday celebrations, the female capital elite - that is, both the native and refugee wives and daughters of the Confederacy's leading politicians, generals, and city officials — sought to re-establish their reign and, in doing so, serve as influential models of moral living and respectability in the rapidly expanding and diversifying Confederate capital. As the wives and daughters of powerful and politically connected slaveholding men, these women were invested with enormous social and cultural authority of their own. Granted both the protection and privilege afforded to them by this patriarchal culture, these women (for the most part) readily embraced the rights and responsibilities of elite ladyship. Both relying on traditional prescriptions of southern ladyship and adapting their behavior to the necessities of the time, these women confronted the crime, rowdiness, lasciviousness, and public disorder caused by shortages, inflation, and speculation through elaborate social performances. Many of these 
performances were often the subconscious byproduct of the cultural milieu in which these southern women were raised - a milieu deeply rooted in public displays of and negotiations for identity, power, and benevolence.

As the war progressed, entangling Richmond in two of the most significant military campaigns of the war, in 1862 and 1864, and funneling thousands more refugees, prisoners, soldiers, prostitutes, blacks, and poor women into the tightly-packed city streets, Richmond's civil war fractured into a series of civic wars in which elite women struggled to re-craft their highly symbolic social interactions accordingly. Specifically, the conversion to hard-war military tactics and the devastating, widespread, Union military campaigns that swept across central Virginia, the Shenandoah Valley, and across the Deep South states throughout 1864 drove thousands of additional destitute women, desperate refugees, questionable characters, and profiteers into the packed Confederate capital. This late-war surge of strangers placed unprecedented pressures on the city's already over-taxed resources and war-weary civilians. In many instances, the toughening conditions and increasing social tensions in the city during the mid- and late-war periods caused many ladies to retreat from the public sphere into "safer" and more intimate social settings, (some of which famously revolved around what many disapproving Richmonders labeled as "inappropriately decadent" parties and balls), and to limit their engagements with the public to even more carefully scripted and strictly guarded interactions.

Undoubtedly, after three long years of war, Richmond's leading ladies—like many other civilians in both the North and the South — were utterly exhausted and felt both physically and mentally worn down by the constant pressures and stresses of civil war. Therefore, it is entirely possible that the roots of this inward turn largely stemmed from personal feelings of emotional 
weariness as a result of the continuous demands that the war relentlessly had placed upon them during the preceding three years. Thus, it is possible that the ladies' late-war isolationism, exclusionism, and even their tendencies toward "inappropriately indulgent" behavior, simply illustrated a subconscious inability to continue to answer the war's call for continued public leadership and sacrifice. (Such war-weariness and personal exhaustion should not, however, be confused with disillusionment with the Confederate cause or, necessarily, with a conscious refusal to continue to support the war effort). ${ }^{5}$

However, this inward turn also may have reflected the inability of the elite to cope specifically with the war's enormous social challenges and its increasing threats to moral order and elite authority. Their retreat to the familiar and perceptibly safer confines of the private sphere thus might have been the elites' defensive response to those threats, as well as to the mounting criticisms of some of their peers and the city newspaper editors who increasingly lambasted the women for their so-called "offensive" and "inappropriate" social conduct throughout the late-war period. The retreat also could be illustrative of a growing sense of denial on behalf of the elite that their world was slowly crumbling to pieces around them, and a belief that, by withdrawing to the exclusive comforts of their own sphere, they might somehow block out or avoid the impending destruction of their way of life. In that light, one might interpret the inward-turning nature of those rituals as reflective of the sheer desperation of Richmond's ladies who, perhaps, may have been attempting to cling to some shred of familiarity, comfort, and stability during the Confederacy's darkest days.

Alternately, the leading ladies' inward-turning behavior, tendencies toward heightened exclusionism, and their careful re-scripting of earlier behaviors and rituals to fit more intimate

\footnotetext{
${ }^{5}$ For a more in-depth discussion on civilian war-weariness, see Susannah J. Ural, Don't Hurry Me Down to Hades: The Civil War in the Words of Those Who Lived It (New York: Osprey Publishing, 2013).
} 
settings, could also represent a conscious (however misdirected) effort to re-direct the spotlight more squarely on them through merely emphasizing their sudden absence from public society. It is possible that the ladies convinced themselves that their conspicuous, increased exclusivism might draw the intrigue of certain sectors of society which, in turn, would provoke heightened attention to their actions - attention which potentially might allow the ladies to continue projecting for society their authority and claims to ladyship, but in a more targeted, manageable, and safer fashion. However, as much as the ladies may have anticipated the "trickle-down" influence of their narrowly-focused late-war rituals, it appears that both their cognitive and physical disconnect from ordinary society appears ultimately to have been too great to bridge, as at least the written coverage of those rituals was, in fact, scant, and (generally) far more critical than it was supportive of the ladies' behavior. In more than a few instances, the leading ladies appear to have actually alienated the very classes of individuals that they had hoped to impress and appease, and ultimately only heightened their critics' disaffection with the war and its elite proponents. Blinded by denial, shock, and the disorienting effects of war, Richmond's ladies often became mentally entrapped in particular modes of thinking and familiar social rituals which, as the war progressed, in reality served more as a comforting series of performances for their own, insular circle of friends than they did as an effective means of broader social ordering. Although it is often difficult to pinpoint an exact, causal relationship between specific episodes of social unrest and a direct shift in elite women's social behavior, the evidence does suggest a growing trend toward withdrawal from public spaces and from the increasing crowds of strangers in the capital city following the Bread Riots of April, 1863, the dramatic surge in city crime during late 1863 into 1864 , the uptick in runaway slaves throughout 1864 , and the increasing rowdiness surrounding the Christmas holiday of 1863 and 1864 . While the ladies 
may have convinced themselves that many of their social rituals would still cast a large public shadow, in reality, these later wartime rituals were often performed merely before a crowd of their peers, revealing a critical disconnect between the reigning ladies and society at large.

Nevertheless, although most of these women perceived their actions as befitting their gender and elevated rank in society, (and that such actions indeed were necessary to the maintenance of their social authority and moral order in Richmond), the women frequently became the targets of sharp-tongued critics. The most vocal of these critics included soldiers, officers, newspaper editors, middling women, and even some of their own peers who scorned the ladies for investing an inappropriate amount of concern and effort into social rituals during a time of war. These diverse groups of critical Richmonders challenged the ladies' social authority — and the ruling class as a whole — throughout the war, and for different reasons, which suggests that the ladies' actions were not always well-received or successful enough to stave off further threats to their position.

However, as a work of cultural history, this project focuses not so much on the causeand-effect relationship between the social rituals of leading ladies and the actual affirmation of their authority and social order as it does on elite women's perceptions of their own social influence. This is due both to the need and desire to delve deeply into the worldviews of elite women themselves in order to uncover their processes of thought and social projection, but also due to the scant amount of detailed primary evidence from the poor, African Americans, and the ordinary women of Richmond. The lack of direct evidence from these lower classes of Richmonders is not surprising. However, capturing the history of the lives of the poor in Civil War Richmond is certainly not impossible, as numerous court records, newspaper articles, Mayor's Reports, City Council Minutes, census and tax records, benevolent society records, 
vestry book minutes, as well as a sampling of letters to, from, and about these individuals reveal significant information about how these people lived, behaved, and misbehaved. Indeed, Emory Thomas, Ernest Furgurson, Carey Latimore, Susan Barber, Amy Minton, and Thomas Lowry, among others, have produced impressive and important work on these individuals in recent years. ${ }^{6}$ Furthermore, I personally have gleaned a significant amount of useful information about Richmond's lower classes by carefully reading through an enormous amount of this material, as noted in both the footnotes and the bibliography.

However, much of this material fails to capture the poor's perceptions of elite women's social performances and the poor's assessments of whether Richmond's leading ladies were successful or not in reinstating their moral order in society. It is thus nearly impossible to infer a causal relationship between elite women's attempts to reaffirm their authority and the traditional social order of the city, and the ensuing behavior of the poor. Such a relationship is merely hinted at during a handful of instances and in rare statements from the poor themselves. Therefore, this project rather studies a core set of elite women's rituals and highly performative social acts — both the careful scripting and execution thereof - to understand better Richmond's leading ladies' views of their social and political roles during the war, as well as their reliance on ritual and performance to reify their notions of authority and moral order in the Confederate capital.

While this project relies on some war-time letters and diary entries written by Richmond ladies, unfortunately, a majority of the most descriptive evidence concerning the ladies' social

\footnotetext{
${ }^{6}$ Emory Thomas, The Confederate State of Richmond: A Biography of the Capital (Baton Rouge: Louisiana State University Press, 1998); Ernest B. Furgurson, Ashes of Glory: Richmond at War (New York: Vintage Books, 1997); Amy Karen Rider Minton, "A Culture of Respectability: Southerners and Social Relations in Richmond, Virginia, 1820-1865," (Ph.D diss., University of Virginia, 2006); Carey H. Latimore, IV, "Always a Minority: Richmond Area Free Blacks in the Civil War Era," (Ph.D. diss., Emory University, 2005); Susan Edna Barber, "Sisters of the Capital: White Women in Richmond, Virginia, 1860-1880," (Ph.D. diss., University of Maryland, 1997); Thomas P. Lowry, M.D., Sexual Misbehavior in the Civil War: A Compendium (Xlibris Corp., 2006); Thomas P. Lowry, M.D., The Stories the Soldiers Wouldn't Tell: Sex in the Civil War (Mechanicsburg, PA: Stackpole Books, 1994; repr. 2012).
} 
rituals resides in edited diaries and memoirs that were published in the post-war period. Such is the case with Mary Chesnut, the prominent socialite and 40-year-old native South Carolinian whose husband, the former United States Senator, James Chesnut, served for a brief time as a Brigadier General in the Confederate army and who later became a private aide to Jefferson Davis. Chesnut's oft-quoted journal, A Diary From Dixie, was compiled during the war years, but underwent heavy revisions by Chesnut in the late 1880s. Chesnut's close friend, Isabella Martin, published the re-revised and abridged version of her diary after in 1905, after Chesnut's death. The diary again underwent revision in 1949, and most famously, in 1983 by noted southern historian, C. Vann Woodward whose impressive annotations thankfully helped to return much of the diary to its original form, thus filling in several missing pieces and correcting numerous errors in the previous editions. However, further complicating matters, Chesnut admits in the latter part of her diary to burning large sections of her journal during Stoneman's Raid on Richmond in early May of 1863 , and then re-writing the destroyed sections from memory. ${ }^{7}$ As C. Vann Woodward notes, Chesnut also painstakingly revised the early part of her diary in later years to erase the initially negative commentary she had written about Jefferson and Varina Davis upon her arrival in Richmond, in $1861 .^{8}$ Chesnut's diary is, therefore, seemingly as much a study in literary memory and representation as it is a record of history.

Similarly, Judith McGuire's Diary of a Refugee During the War, published in 1867, is the byproduct of both a wartime journal and a series of post-war revisions by McGuire herself. A Richmond native, but war-time refugee from Alexandria, McGuire was the 58-year-old wife of Reverend, and later, Confederate Post Office Department worker, John Peyton McGuire. As James I. Robertson, Jr. points out in his recent annotated edition of the diary, McGuire made a

\footnotetext{
7 Mary Boykin Chesnut, Mary Chesnut's Civil War, ed. C. Vann Woodward (New Haven: Yale University Press, 1981), xviixviii.

${ }^{8}$ Chesnut, xix-xx.
} 
series of revisions to her manuscript in 1866 and 1867, many of which attempted to clarify or correct previous mistakes, but McGuire frequently made these revisions from memory. Several of McGuire's revisions ultimately obfuscate her diary further through incorrect "corrections" of dates, names, and chronology and through contradictory and exaggerated representations of specific events that were due both to her failing memory and to her attempts to re-craft the diary for appropriate public consumption. ${ }^{9}$ Thankfully, with both Mary Chesnut's and Judith McGuire's diaries, excellent investigative and annotation work by prominent historians has helped to separate fact from fiction in these works, or has at least provided helpful context and cautionary advice for wading through these complicated, heavily "constructed" works of history.

Fortunately, several of the other women that play prominently in this dissertation have left behind a handful of wartime correspondence and unaltered, unpublished wartime diaries and journals that have proved immensely helpful both in fleshing out the content of this project but also in helping to corroborate the postbellum memoirs of their peers. These wartime writers include 35-year-old Varina Davis; 21-year-old Detroit transplant and Richmond hospital matron, Kate Mason Rowland; 49-year-old, Jewish, North Carolina transplant, Emma Mordecai; and San Antonio native and refugee, 22-year-old Anita Dwyer Withers, whose husband, John held a Lieutenant Colonel's commission in the Confederate army.

However, several of the women who have provided some of the most in-depth and analytical assessments of Richmond's social scene during the Civil War recorded those thoughts almost entirely in memoirs that were published in the post-war years. These women include 30year-old Sallie Putnam, a native of Madison County, Virginia and 1858 transplant to Richmond, whose memoir, Richmond During the War, was published in 1867; and 18-year-old Nansemond

\footnotetext{
${ }^{9}$ Judith Brockenbrough McGuire, Diary of a Southern Refugee During the War: Annotated Edition, James I. Robertson, Jr., ed. (Lexington: The University Press of Kentucky, 2013), 7.
} 
County native and war-time refugee, LaSalle Corbell Pickett, third wife of the famous Confederate General, George E. Pickett, who published her two memoirs, Across my Path: Memories of People I Have Known and What Happened to Me..., in 1916 and 1917, respectively. An adamant defender of the "Lost Cause," Pickett's numerous post-war writings overflow with unending praises for her husband and romantic portrayals of the Confederacy at war. Noted nineteenth-century journalist and social commentator, T.C. DeLeon of South Carolina, makes similar claims about the wartime South in his memoirs, Four Years in Rebel Capitals (1892), and Belles, Beaux, and Brains of the Sixties (1909).

Other elite women who feature prominently in the pages that follow have left behind a combination of detailed post-war memoirs and a sampling of wartime correspondence, only some of which is helpful in corroborating the postbellum publications. Such is the case for 38year-old South Carolina native and refugee, Phoebe Yates Pember, whose 1879 memoir, $A$ Southern Woman's Story: Life in Confederate Richmond, chronicles Pember's experiences working as the chief matron at Richmond's Chimborazo Hospital for two and a half years; 37year-old North Carolina native and former Alabama resident, Virginia Clay, the wife of Confederate senator Clement C. Clay and author of Belle of the Fifties (1904); and 18-year-old Mississippi native and wartime refugee from Maryland, Constance Cary, author of Recollection Grave and Gay (1911) and proud member of the celebrated trio of Richmond wartime belles, the "Cary Invincibles."

The dates of this type of source material are not ideal, as issues of memory, post-war bias, and Lost Cause revisionism have tainted significant portions of some of this evidence. Rosy images of elite women unhesitatingly welcoming the scores of new arrivals, regardless of class position, into the city and into their homes abound in this material, as do stories of elite 
women happily and whole-heartedly joining together with their "less fortunate sisters" — and even their slaves - in patriotic sacrifice for the war effort. Class distinctions tend to melt away in many of these narratives and many of the ladies have either completely ignored or glossed over several key moments of social tension in the city, the extent of their criticism by others, and the reality of their disconnect from the broader community in the capital city.

Some of this revisionism is undoubtedly the sub-conscious byproduct of a defeated people's denial about their own potential complicity in the failure of the Confederacy and the result of a perceived need for a collective Confederate memory that glorified the unflinching loyalty, unity, and devotion of the South's war heroes and the women who supported them. However, often, this revisionism stemmed from a conscious attempt to re-politicize the nature of the war to the South's advantage in order to protect the sacred memory of the Confederate dead and recast the Confederacy in a positive light. Such revisionism often "overlooked" critical moral, political, and social fissures such as slavery, an overly rigid social hierarchy that induced immense class conflict under the strains of war, and a staunch parochialism that contributed to the failure of the grand Confederate project. As Edward Ayers, Caroline Janney, David Blight, William Blair, George Rable, Gary Gallagher, and Drew Gilpin Faust, among others, have noted, former Confederates - and, often many northerners as well-jointly crafted a neat and tidy narrative of Confederate military glory and a unified home front that was unceasingly devoted to the just and moral "cause" of Confederate independence, in order to patch up the deep sectional wounds of the post-war era and achieve inter-sectional racial solidarity over the swelling, free African-American population. ${ }^{10}$

\footnotetext{
${ }^{10}$ Edward L. Ayers, What Caused the Civil War?: Reflections on the South and Southern History (New York: W.W. Norton \& Company, 2005); Edward L. Ayers, The Promise of the New South: Life After Reconstruction (New York: Oxford University Press, 1992; reprint, 2007); Caroline E. Janney, Burying the Dead, But Not the Past: Ladies' Memorial Associations and the Lost Cause (Chapel Hill: The University of North Carolina Press, 2008); David W. Blight, Race and Reunion: The Civil War in American Memory (Cambridge: Harvard University Press, 2001); Drew Gilpin Faust, Mothers of Invention: Women of the
} 
Alternately, I have also contended with several scathing post-war accounts of Richmond ladies' social behaviors that deny that little, if any, solidarity ever existed amongst any Richmonders at any time during the war. Many of these accounts appear to have been written (or corroborated) by individuals whose sole attempt was to deflect blame for the failure of the Confederacy off of the shoulders of the South's frontline defenders, and by angry, frustrated, or envious Richmonders who either felt slighted by the elite, or who desperately sought an easy scapegoat for Confederate defeat. Although these writers make numerous critiques of the female elite that are doubtlessly true, their bitter resentment toward the "selfish and materially-focused" leading ladies appears to have been fueled more by their own anger and frustration rather than by purely fact itself.

Wading through the post-war writings of and about these women in search of "authentic" accounts of their wartime thoughts and behaviors therefore has been a particularly challenging, though not impossible task. As with wartime evidence, I have grappled with these post-war publications by the ladies, newspaper editors, refugees, soldiers, politicians, and middling women by searching for corroborating evidence in other contemporary sources, such as wartime newspapers, minute books, letters, and journals and by trying to read between the lines and against the grain of the evidence itself for potential biases, exaggerations, and misrepresentations - however intentional or unintentional. I have also spent a significant amount of time analyzing key silences in my source material and the potential reason for their (often, surprising) presence. Although even the closest and most careful readings of such evidence occasionally fail to decipher truth from fiction and leave historians merely to draw their own,

Slaveholding South in the American Civil War (Chapel Hill: The University of North Carolina Press, 2001); George C. Rable, Civil Wars: Women and the Crisis of Southern Nationalism (Tuscaloosa: University of Alabama Press, 1991); William Blair, Cities of the Dead: Contesting the Memory of the Civil War in the South, 1865-1914 (Chapel Hill: The University of North Carolina Press, 2004); Gary Gallagher and Alan T. Nolan, eds., The Myth of the Lost Cause and Civil War History (Bloomington: Indiana University Press, 2000; reprint, 2010); see also, Edward Alfred Pollard, The Lost Cause: A New Southern History of the War of the Confederates (New York: E.B. Treat \& Co. Publishers, 1867). 
best possible conclusions from the evidence at hand, I have tried to analyze this material critically and include only those bits of evidence that seem to fit in with other, wartime material and are widely supported by the secondary source material listed in the bibliography.

Expectedly, I found statements in both wartime and post-war sources that directly contradicted each other, as well as personal observations and accounts of events and emotions that flatly contradict accounts from preceding chapters, if not pages. During these instances, I again tried to make sense out of the contradictions by looking for additional context and evidence to sort out truth from fiction and to uncover potential factors or influences that may have produced such a dichotomy. Throughout this project, I have striven to make special note of several of the more significant, more obvious, or more controversial instances of conflicting or patchy evidence noted by other scholars. Such methodology clearly has forced me to draw some conclusions from the evidence with which other scholars might disagree. However, I firmly believe that my reading and contextualization of the evidence supports the claims I make in the following chapters. I also believe that we can still glean valuable insight from these postwar accounts about the needs and expectations of society that the female elite were trying to fulfill (whether they did so in reality or not) through their various social rituals, which they wanted to believe — both during and after the war — were morally just and successful. Therefore, while the elites' recounting of these rituals may not always represent the truthful unfolding of the events themselves, they do help to provide insight into how the elite may have intended them to unfold, how the elite perceived and wanted to remember them as having unfolded, and how the elite sought to represent those events through writing in order both to comfort themselves and shape the public's historical memory. 
The women around whom this project focuses have left behind far fewer letters and detailed wartime accounts about their social interactions and perceptions of society than I had expected upon commencing my research. There is, of course, a significant amount of information to be gleaned about elite women's behaviors and worldviews even from the shortest and most mundane wartime letters and diary entries, and I have used that information to flesh out some of my main arguments. However, the surprising paucity of contemporary evidence may be due to several factors. First, many of these women (both native Richmonders and refugee women) understandably spent a majority of their letters and diaries discussing family matters with and about distant husbands, brothers, parents, and siblings-i.e., who was sick, how a brother/cousin/father in the army was faring, did everyone have enough to eat back at home, what did others hear about the most recent military actions, etc. Secondly, the ladies' letters often focused on personal matters of practicality and discussed issues of money, clothing supplies, and transportation to and from different locations. Much of the ladies' writings about their daily social interactions were kept fairly short and to the point, and did not contain a significant amount of reflection. During a time of war, this style of practical writing and mere "note-taking" on daily events in journals would be expected.

Thirdly, due both to military circumstances, such as raids and threats to the Confederate capital that compelled elite women temporarily to flee the city in order to protect themselves, and to the monetary means and the traveling proclivities of many of Richmond's ladies, several of the female elite were frequently absent from the city during key moments of social unrest. Such was the case during the Richmond Bread Riots of April 2, 1863. The ladies' absence during some of the most iconic instances of social tension in the city has contributed to much of the 
surprising silence in the ladies' memoirs, diaries, and letters regarding their reactions to such tensions.

A final reason for the scarcity of intricate social discussion in war-time letters and journals rests in the simple fact that, as the chapters that follow reveal, the ladies of Richmond socialized nearly constantly throughout the whole war; doubtless, many of the details of their innermost thoughts, conversations, and commentary on their social situation in Richmond exist only as silent echoes in the memories of the delicate furnishings, draperies, and parlor chambers in which those conversations took place. Therefore, it is unsurprising that so many of the details of this social commentary (outside a core set of contemporary letters and postbellum diaries and memoirs) still elude researchers today.

Additionally, while all of the women quoted in the pages that follow directly discuss their disgust or concern over the mounting social threats and disorder in Richmond (though to different degrees), it is not surprising that they do not as frequently or directly address how they, personally, sought to combat the social tensions in the city. One explanation for this silence is that their responses to such challenges were intuitive to the point of sub-conscious reaction; that is, these women discuss their social behaviors (again, to differing degrees), but don't feel the need to explain the symbolism or intent behind these behaviors, as the meaning of their behaviors was so naturally ingrained in both their conscious and sub-conscious thinking that such explanations would be unnecessary or even inexpressible. Rather it is up to us, as historians, to try to read between the lines of their descriptions of their behavior, by juxtaposing those descriptions against contemporary newspaper accounts, public records, and the writings of fellow Richmonders regarding social threats, unrest, and the need to quell such tensions, in order to decipher the symbolic meaning behind those actions and the worldviews that framed them. 
In selecting my "cast of characters" for the dissertation, I looked not only for women who left a detailed and significant enough paper trail to be featured in this study, but I also sought out women who appear to have been more self-reflective and committed to maintaining a high production of written material throughout the four years of war. It is often impossible - if not even potentially irrelevant - to make a case for a group of individuals as "representative" of their class, gender, race, or place in society, and I make no such claims here. Rather, I have chosen to focus on this specific set of women because the breadth, depth, and sheer extent of their writings offer the opportunity for an in-depth analysis of their worldviews and behavior, and also enable us to study change over time in a concentrated set of individuals. The combined writings of, about, and contextualizing these ladies reveals a powerful truth about how a solid group of elite Richmond women perceived and made sense of their surroundings, their authority, and their responsibilities. By analyzing these women's representation of those perceptions and of the world around them through the written word, this project resists making blanket statements about all elite women, or even about all upper-class women of Richmond. Rather, it illuminates specific patterns of thought and expression — that is, the ways in which the Civil War shaped leading ladies' conceptions of themselves, their peers, and society, and the ways in which those conceptions manifested themselves in a, thus far, largely ignored or misunderstood complex set of social rituals.

Historians who have examined the social order within the Confederacy indeed, heretofore, have neglected to study these daily social practices within the context of performing power, or, publicly showcasing one's social power through a cultural event that both highlights the social dominance of one individual or group over another and serves as a powerful display of the social mores that dictate that hierarchical ordering of society. Richmond is ideal for such a 
study of power dynamics not only because of its role as the political seat of government during those four years. The city also served as a popular and fluid social center for both free and enslaved African-Americans, refugees and impoverished Confederates (particularly women) from all over the South; as a cultural model of "proper Confederate society" and promoter of morale for the larger nation; and as a microcosm of some of the most dynamic and intriguing social transformations in the war-time South. Generally speaking, this project reveals how individuals have relied on unofficial and often informal social interactions as rituals through which they sought both to reaffirm their own contested identities and to affect broader social change upon society as a whole. Specifically, my analysis of the social conventions, levees, parties, balls and charitable acts ultimately reveals the female capital elites' use of informal social relations, social politics, and cultural events to uphold the morale and unity among Richmond's capital elite; to stabilize a society at war; to foster engagement between various social groups in Richmond; and, ultimately, to soften class and communal tensions while simultaneously reinforcing the city's cherished social hierarchy on a daily, long-term, basis.

Like many other east-coast cities during the middle of the nineteenth century, Richmond had already endured two uneasy decades of social unrest during the large German, Irish and Jewish immigrations across the eastern seaboard. Theft, burglaries, prostitution, public drunkenness and gambling were endemic, and weekly stabbings, shootings and murders were not uncommon. Unsurprisingly, the provincial elite of 1860s Richmond society disdained the prospect of competing with even more new interests—both monied and poor — or of embracing the hordes of wayfaring politicians, refugees, job-seekers, "paupers," and other outsiders misplaced by the unfolding military conflict as they flooded into the city. ${ }^{11}$

\footnotetext{
${ }^{11}$ Kate Pleasants Minor, "Richmond in the Sixties," box 2, Southern Women's Collection, Eleanor S. Brockenbrough Library, Museum of the Confederacy (Richmond, VA), 9.
} 
Haltingly, Richmond unlocked its doors to the thousands of strangers, newcomers, and a rising number of impoverished city-dwellers who arrived within the Confederate capital. Perpetually wary of the potential threats that such newcomers and social "others" might pose to the existing social order of the city, Richmond's capital elite initially maintained social barriers not only between various social classes, but also between native Richmonders and strangers. To Sallie Putnam, such boundaries seemed absolutely essential, as "wickedness" abounded, spies were omnipresent, and around every corner there was a stranger using "specious pretexts" to try and gain his or her way into high society. ${ }^{12}$ The situation grew so dire in Richmond that, in 1863, the city was forced to publish a "Strangers' Guide and Official Directory for the City of Richmond" in order to help newcomers decipher upright and trustworthy businesses, neighborhoods, and groups of people from those of the pretending confidence men and women of the Confederate Capital. ${ }^{13}$ Ultimately, however, the tide of newcomers proved too difficult simply to shut out and ignore, and the elite were forced to interact and engage with them on a daily basis while they simultaneously struggled to maintain the appropriate social distance befitting their class position.

This dissertation illuminates how they did so. It begins with an analysis of who, exactly, comprised the class of women known as the capital elite, how these individuals established themselves as societal leaders, and why they were significant. It then continues with an examination of the nature of inter-class engagement between the capital elite and the lower classes, including blacks and refugees. Such engagement includes the ladies' conversations with, direct assistance to, and observations of the poor which, in turn, altered both the nature of the elites' relationship with the poor and elite behavior itself over the course of the war.

\footnotetext{
12 Putnam, 77, 211, 255; for corroborating evidence about these fears, see also, Thomas, 66-70.

13 Putnam, 255.
} 
In combining the historiography on elite southern women, the historiography of southern benevolence $^{14}$ and a core set of cultural theories ${ }^{15}$ with my primary research and secondary source reading, this dissertation accomplishes two goals: First, it uncovers how the female capital elite perceived their world, their evolving social identity, and their social responsibilities in relation to their peers during the Civil War, and second, it illuminates how the city's leading ladies tried to use both their shared understanding of the world and their shared cultural systems to try to stabilize class and social divisions, while simultaneously attempting to reaffirm the cherished social hierarchy of the Confederate capital through social events and cultural rituals. In doing so, this dissertation adds a critical element both to our understanding of the worldview of this important group of women and to our comprehension of the inner workings of the power dynamics within the diverse Confederate capital. ${ }^{16}$

\footnotetext{
14 A significant amount of scholarship exists on nineteenth-century benevolence. For example, see, see the following: Lori D. Ginzberg, Women and the Work of Benevolence: Morality and Class in the Nineteenth-Century United States (New Haven, CT: Yale University Press, 1990); Bruce Dorsey, Reforming Men and Women: Gender in the Antebellum City (Ithaca, NY: Cornell University Press, 2002); Thomas Haskell, "Capitalism and the Humanitarian Sensibility," in The Antislavery Debate: Capitalism and Abolitionism as a Problem in Historical Interpretation, ed. Thomas Haskell (Berkeley, CA: University of California Press, 1992); Timothy James Lockley, Welfare and Charity in the Antebellum South (Gainesville, FL: University of Florida Press, 2007); Elna C. Green, This Business of Relief: Confronting Poverty in a Southern City, 17401940 (Athens: The University of Georgia Press, 2003); Kenneth Greenberg, Honor and Slavery (Princeton: Princeton University Press, 1996); Eugene Genovese, Roll, Jordan, Roll: The World the Slaves Made (New York: Vintage Books, 1976); Eugene Genovese, "Yeomen Farmers in a Slaveholders' Democracy," Agricultural History 49, no. 2 [April, 1975]; Christine Jacobson Carter, Southern Single Blessedness: Unmarried Women in the Urban South, 1800-1865 (Chicago: University of Illinois Press, 2006).

15 See Clifford Geertz's theories of "thick description" and "cultural anthropology," in Clifford Geertz, qtd. in Peter Burke, What is Cultural History? 2nd ed. (Malden, MA: Polity Press, 2004. Reprint, 2008). See also, Eugene Genovese's and T.J. Jackson Lears' theories of "paternalism" and "cultural hegemony," in Eugene Genovese, Roll, Jordan, Roll: The World the Slaves Made (New York: Vintage Books, 1976); Eugene Genovese, "Yeomen Farmers in a Slaveholders' Democracy," Agricultural History 49, no. 2 [April, 1975]: 331-342; and T.J. Jackson Lears, "The Concept of Cultural Hegemony: Problems and Possibilities," The American Historical Review 90, no. 3 [June, 1985]: 567-593. See also, Daniel Wickberg's theory of "sensibilities," in Daniel Wickberg, "What is the History of Sensibilities? On Cultural Histories, Old and New," The American Historical Review 112, no. 3 [June, 2007\}: 661-684. See also, Bertram Wyatt-Brown's work on "southern honor," in Bertram Wyatt-Brown, Honor and Violence in the Old South (New York: Oxford University Press, 1986). See also, Rhys Isaac's theory of "dramaturgical ethnography," in Rhys Isaac, The Transformation of Virginia, 1740-1790 (Chapel Hill: The University of North Carolina Press, 1982.; repr. 1999).

16 My work has also been heavily influenced by the scholarship of Karen Halttunen on social etiquette and cultural performance in nineteenth-century America, in Karen Halttunen, Confidence Men and Painted Women: A Study of MiddleClass Culture in America, 1830-1870 (New Haven, CT: Yale University Press, 1982); and by Steven Stowe's scholarship on social performance and power dynamics in the Old South, in Steven M. Stowe, Intimacy and Power in the Old South: Ritual in the Lives of the Planters (Baltimore: Johns Hopkins University Press, 1987). My work also is informed by, and seeks to converse with, the scholarship by historians of southern culture, southern women, and politics, such as William Blair, Charles Dew, Nina Silber, Stephanie McCurry, and Walter Johnson. See, William Blair, Virginia's Private War: Feeding Body and Soul in the Confederacy, 1861-1865 (New York: Oxford University Press, 1998); Charles B. Dew, Apostles of Disunion:
} 


\section{Richmond Reborn: A Brief Overview of The Capital City in Transition}

In 1907, noted travel writer and social commentator, Thomas Cooper DeLeon reflected upon the many years he spent in Richmond, Virginia observing the people, places, and events which, he believed, formed the backbone of the city's unique character. DeLeon had enjoyed both the opportunity to witness the city's growth from a small antebellum city to a veritable metropolis during the Civil War, as well as the elite privilege to participate in the thriving social scene dominated by Richmond's upper-class residents. ${ }^{17}$ As he watched the Confederate capital's population of 38,000 explode into 150,000 residents between 1861 and 1865, DeLeon noted the wariness and caution with which native, upper-class Richmonders responded to the city's influx of refugees, politicians, soldiers, businessmen, entrepreneurs, and both free and enslaved African Americans. In his memoirs, DeLeon perfectly captured the tension and suspicion that pervaded the air as the Richmond elite made their first observations of the incoming tide of strangers to their city in 1861 :

In the city, where class sometimes jostled privilege, the line of demarcation was so strongly drawn that overstepping was dangerous. When the news came that patriotism dictated the abandonment of inland Montgomery for border Richmond, a surprise that was not all pleasurable thrilled to the finger-tips of Richmond society. Its exponents felt much as the Roman patricians might have felt at impending advent of the leading families of the Goths. Her sacred fanes might

Southern Secession Commissioners and the Causes of the Civil War (Charlottesville: The University of Virginia Press, 2002); Nina Silber, Gender and the Sectional Conflict (Chapel Hill: University of North Carolina Press, 2009); Stephanie McCurry, Masters of Small Worlds: Yeoman Households, Gender Relations, \& the Political Culture of the Antebellum South Carolina Low Country (New York: Oxford University Press, 1995); Stephanie McCurry, "The Two Faces of Republicanism: Gender and Proslavery Politics in Antebellum South Carolina," Journal of American History [March, 1992]: 1245-1264; Stephanie McCurry, Confederate Reckoning: Power and Politics in the Civil War South (Cambridge: Harvard University Press, 2012); Walter Johnson, "A Nettlesome Classic Turns Twenty-Five," Common-Place 1, no. 4, [July, 2001]. <http://www.commonplace.org/vol-01/no-04/reviews/johnson.shtml>; Walter Johnson, Soul by Soul: Life Inside the Antebellum Slave Market (Cambridge: Harvard University Press, 1999).

17 Born in Columbia, South Carolina to distinguished Spanish and Sephardic Jewish parents in 1839, Thomas Cooper DeLeon was a well-known journalist, author, and playwright. He served as a Captain in the Confederate Navy, as Chief Clerk in the Office of Pay, and as a personal secretary for Jefferson Davis. His brother Edwin was as a Consul General to Egypt under the Pierce and Buchanan administrations and served as a Confederate envoy in Europe. His brother David was appointed the first Surgeon General of the Confederacy. After the war ended, T.C. DeLeon worked as an editor for the Mobile Register, The Gossip, and The Gulf Citizen while he wrote his many plays, travel memoirs, and poetry. Completely blind by 1903, DeLeon died in Mobile, Alabama in March, 1914. 
possibly be desecrated by profane touch, her Vestal Virgins viewed by vulgar eyes. At first blush of the new invasion it is assumable that older Richmond was ready to bolt the front door and lock the shutters. Younger Richmond perhaps was curious enough to peep between them. ${ }^{18}$

An astute judge of social dynamics and interpersonal relationships, T.C. DeLeon easily understood the threat to social order and community stability that the newcomers posed to the well-to-do Virginians, whose “...[G]reat family connection ramified into a meshed and interwoven consanguinity that held the interest of neighborhoods and through them, of all the Dominion, bound to common aspiration and to common interest." ${ }^{19}$ Prior to the Civil War, the waves of Irish, German, and Jewish immigration that swept the eastern seaboard had already produced several years of rapid growth, diversification, and social unrest in relatively traditionalist Richmond. The arrival of yet thousands more strangers of varying races and socioeconomic backgrounds during the war alarmed the city's elite residents whose social power, political leadership, and economic well-being lay rooted in a rigidly ordered and highly stratified society in which everyone knew each other's roles, rights, and responsibilities. ${ }^{20}$

With roots that proudly dated back to Virginia's seventeenth-century heritage, antebellum Richmond had largely succeeded in maintaining a parochial social hierarchy based upon wealth and aristocratic family privilege. As T.C. DeLeon observed,

[F]amily first, with the concomitant of polish, education and 'manner' were the sole 'open sesame' to which the doors of the good old city would swing wide...Law, physic, the church... were [alone] permitted to condone the 'new

\footnotetext{
18 T.C. DeLeon, Belles, Beaux and Brains of the 60's (New York: G.W. Dillingham Company,1907), 51. The twentiethcentury publication date of DeLeon's memoirs might, understandably, raise questions about the influence of nostalgia, bias, and memory upon his recollections. However, the wartime newspapers, diary entries, and correspondence of women such as Varina Davis, Mary Chesnut, and Judith McGuire (whose revisions to her 1867 memoir recently have been found to be quite spare by historian James Robertson, Jr.) that are cited throughout this dissertation seem to corroborate DeLeon's general portrayal of Richmond in the late antebellum and early-war era, despite the 46 year gap between the events he describes and the date he published his memoirs.

19 DeLeon, 21. Also, see above note.

${ }^{20}$ Richmond Examiner, May 24, 1861, July 15, 1862 ; Putnam, 76-68; Emory Thomas, The Confederate State of Richmond: A Biography of the Capital (University of Texas Press, 1971); reprint, (Baton Rouge: LSU Press, 1998), 25, 65-68; Joan E. Cashin, Varina Davis: First Lady of the Confederacy (Cambridge, MA: The Belknap Press of Harvard University Press, 2009), 111.
} 
families.'...'[S]acred soil' and the sacred social circle were paralleled in the minds of their possessors. ${ }^{21}$

That such a rigid hierarchy still dominated Richmond's social scene by 1860 is remarkable, considering its rapidly modernizing and diverse industrial economy. In 1860, although the city only ranked twenty-fifth in population, it stood as thirteenth in manufacturing. For years, Virginia's capital city had served as an active seaport for global commerce along the James River, and its elaborate canal system and five railroads allowed for constant traffic and an impressive exchange of both goods and people from around the world. It also boasted twelve flour and meal mills, fifty-two tobacco manufacturers, seven main warehouses, woolen mills, an exchange, six tobacco factories and two cigar makers. ${ }^{22}$

Additionally, merchants, blacksmiths, carriage-makers, bricklayers, coopers, cobblers, and saddlers enjoyed a thriving business within the city's confines. The city also was the home of the largest iron industry in the South, which employed 1,550 workers and produced two million dollars in sales each year. Of Richmond's four rolling mills, fourteen foundries and machine shops, nail works, six manufacturers of iron railing, two circular saw-works, and fifty iron and metal works, none was more famous than the Tredegar Iron works, owned and operation by the distinguished Joseph Reid Anderson and employing 900 men alone. Richmond's active domestic slave trade also fueled the city's economy and attracted a diverse mix of traveling merchants and planters who regularly frequented Richmond's premier hotels, such as The Ballard, The Exchange, The Spotswood, and The American, and who contributed to an already thriving business in hospitality. ${ }^{23}$ However, most of these visitors were merely that:

21 DeLeon, 59; see also, Cashin, 111.

22 Thomas, 21-23; also see, Gregg D. Kimball, American City, Southern Place: A Cultural History of Antebellum Richmond (Athens: University of Georgia Press, 2000), 3-80.

23 Thomas, 21-23; also see, Kimball, 3-80. 
short-term guests of the city who, upon completion of their business, ultimately returned to their various homes outside of Richmond.

Richmonders adapted surprisingly well to the presence of this large and varied workforce required to sustain such economic flowering, as well as to the constant flux of transitory businessmen, tradesmen, merchants, and slaves in and out of their city that made Richmond's economic success so viable. Social relations were remarkably harmonious in 1860. Such stability may have been due to the separation of residential communities according to social standing. Members of the upper class tended to segregate themselves along the high ground of the city located on Marshall, Grace, Franklin, and Cary Streets. Though considerably less wealthy than their superiors, middle-class merchants, tradesmen, shopkeepers, and manufacturers generally shared the same set of social and moral values as the upper class, and thus circulated through many of the same public spaces frequented by members of the upperclass. Additionally, these middle-class residents tended to congregate in neighborhoods bordering the upper-class community.

The lower classes of skilled and semi-skilled laborers tended to cluster around Oregon Hill, the backdrop to Richmond's industrial waterfront; along the low ground near the James River, in Penitentiary Bottom and Shockoe Bottom; and on the eastern outskirts of the city, near Rockett's Landing, where they lived in shack and shanty communities often broken down by ethnicity (German, Irish, etc.) and by race. In 1860, Richmond hosted a population of 2,576 free blacks and 11,739 slaves whose presence, according to scholars such as Emory Thomas, most likely helped to unify whites from different classes along racial lines. ${ }^{24}$

That is not to say that Richmond was immune from class tensions and conflict before the Civil War. Vice and crime amongst the lowest classes of laborers, immigrants, and both free and 
enslaved African-Americans occurred on a regular basis. Shootings, stabbings, garrotings, robberies, debaucherous drinking, prostitution, and gambling frequently filled the daily 'Mayor's Court" and "City Items" columns of the Richmond Daily Dispatch, Richmond Enquirer, Richmond Examiner, and the Richmond Whig. ${ }^{25}$ Additionally, the city newspapers contain numerous editorials and commentary by anxious citizens who were concerned about the influences of the "lowly sort" upon the fate of society, and who feared for the moral upkeep of the city. ${ }^{26}$

Despite these inherent class conflicts and frequent moral concerns, strict laws regulating drinking, gambling, prostitution, and other criminal acts, as well as a series of "black codes" that regulated the legal and social behaviors of black residents, both helped to prevent vice and crime, and "cure" Richmond of any trends toward mass depravity. ${ }^{27}$ In addition, careful segregation of public and private spaces, as well as strict regulation of access to and behavior within both public and private spaces according to class, race, and social status helped, for the most part, to preserve the integrity of both the city in general, and its upper-class residents in particular. ${ }^{28}$ By 1860 , though they certainly did not approve of it, city-dwellers had grown accustomed to the moderate, but seemingly controllable, levels of crime, vice, and rowdy behavior endemic to any nineteenthcentury city. Indeed, Richmonders took particular pride in the fact that their city's reputation for good character and respectability surpassed that of many other urban hubs — particularly those in the North, such as New York and Philadelphia, but also southern cities such as New Orleans and Atlanta. $^{29}$

\footnotetext{
25 Thomas, 26; Thomas P. Lowry, M.D., Sexual Misbehavior in the Civil War: A Compendium (Xlibris Corp., 2006);

26 Thomas, 26.

27 Thomas, 19, 27-30.

28 Thomas, 27-30; also see, Kimball, 3-80.

29 Thomas, 19.
} 
A significant contributor to such respectability derived from Richmond's successful, formalized institutions of city government, including aristocratic leadership under the distinguished mayor Joseph Mayo, a Mayor's Court comprised of fifteen alderman, a Hustings Court judge, and a City Council invested with the authority "to make and enforce rules and ordinances" which "they shall deem necessary for peace, comfort, convenience, good order, good morals, health and safety of said city." Standing committees successfully monitored the workings of entities such as the city police, the markets, Richmond's several orphanages and schools, and the Overseers of the Poor who, in 1860, opened a brand new workhouse for the city’s mere "paupers." 30

However, Richmond also appears to have relied upon the moral leadership and good example set by the city's elite residents. These Richmonders were avid supporters of the church and Christian values and of the widespread education and moral tutelage of the Richmond youth. They ardently supported the civic enforcement of good behavior, and themselves relied upon authoritative acts of charity and benevolence, carefully crafted projections of elite identity and moral living, and involvement in established cultural rituals and social engagements to help maintain a well-ordered and upright society. ${ }^{31}$ At the onset of war, Richmonders were so confident in the ability of their so-called "unique" society to absorb and even profit from the exciting social and economic opportunities of war that the local newspapers reported a surprising sense of excitement and eager anticipation to see what the war might bring to the newly minted capital city. ${ }^{32}$

However, all too quickly Richmonders began to realize that the rapidly swelling, diverse, and in many instances, unsavory wartime population was stretching and straining both the formal

\footnotetext{
30 Thomas, 24-25.

31 See Thomas, 24-31.

32 Richmond Examiner, January 31, 1862.
} 
and informal institutions of power and moral tutelage to unimagined degrees. Richmonders feared for the capacity of those institutions fully to contain the swarms of strangers and the challenges that they posed to traditional social order. ${ }^{33}$ Richmond's ladies were appalled by what was happening to their city and by the rapidly changing and devolving character of their community. Certainly it was more than enough work to police the morals and respectability of the thousands of new male strangers invading the Confederate capital, but to also have to serve as the caretakers of thousands more impoverished women and children, and to have to constantly guard the sacred social position of the female elite from the swarms of "greedy" strangers seemed utterly overwhelming. How, these ladies wondered, would they ever be able to establish their social rule over the motley group of newcomers without inciting the jealous anger of this rowdy and raucous mob?

${ }^{33}$ Richmond Examiner, March 5, 1864. 


\section{Chapter 1--Keeping up Appearances:}

\section{House Visits and the Establishment of Richmond's Capital Elite}

In the early winter of 1864, refined young South Carolina belle, Sarah "Buck” Preston expressed her shock upon hearing that a local doctor by the name of Garnett refused to admit a visiting "non-FFV" (First Family of Virginia) into his impressive mansion. Despite the fact that the visitor was well-educated, had good manners, and was even in the process of writing his own book, Dr. Garnett refused to let him into his house simply because of his lack of "native blood." Herself a refugee in the Confederate capital, Buck reflected candidly to renowned South Carolina socialite, Mary Chesnut, upon her own first impressions of Richmond society upon her arrival to the city several years earlier:

Well, until we came here, we never heard of our social position. We do not know how to be rude to people who call. Dear Mrs. Chesnut, did you ever hear of your social position at home? No, I thought so. To talk of that sort of thing seems so vulgar. Down our way that sort of thing was settled beyond a peradventure. We never gave it a thought. We talked to whom we pleased... and we were ever so much politer to poor things. After all, what harm does he do $?^{34}$

However much Buck may have exaggerated the lack of clear social stratification within her native Columbia, South Carolina, she clearly saw a significant difference between the two cities' delineation and enforcement of class and social identity. Richmond, it appeared, seemed emphatically more committed to maintaining strict social barriers not only between classes, but also between native and non-native Virginians of the upper class. With both the public and private sectors committed to preserving the purity of the native Virginia elite, it seemed nearly impossible to many wealthy, refugeeing newcomers to ever be able to break into that coveted inner circle, let alone establish themselves as rightful members of the elite class before both their wealthy peers and Richmond society as a whole.

\footnotetext{
${ }^{34}$ Mary Boykin Chesnut, Mary Chesnut’s Civil War, ed. C. Vann Woodward (New Haven: Yale University Press, 1981 ), 585.
} 
Buck's early experiences in the newly minted Confederate capital illuminate the immense challenges that the Civil War and its ensuing mass migrations posed both to elite women's claims to ladyship and to the traditional social order of Richmond. Although both the city government and the Confederate government quickly expanded the scope of their authority over the Confederate capital with the institution of martial law in March of 1862, the fortification of existing legal and political institutions to accommodate the increasing population, and the creation of new laws and regulations regarding public behavior, food distribution, and economic activity, the Richmond elite feared for the "sacred fanes" of their beloved society. ${ }^{35}$ Apparently, President Jefferson Davis's suspension of the writ of habeas corpus and his prohibiting the production and sale of liquor within city limits would not stop the proliferation of crime and vice within the Confederate capital. The expansion of military police authority, as well as the increase in the size of the city's police department and the city's crackdown on gambling dens and houses of prostitution, could only do so much to curtail the depraved behavior exhibited by Richmond's newcomers and spreading throughout the ranks of lowly native Richmonders. Immediately, the native members of Richmond's upper classes sprung into action with unprecedented force in order to confront and control what appeared to be the threat of mass social chaos evolving around them.

Much to the frustration of the ladies of Richmond, the onset of war quickly drained Richmond of a large segment of its young male population who rushed off to join the burgeoning Confederate army. For most of the men who remained at home, the immediate demand for wartime labor in the iron foundries, the armory, on the railroads, in the surgeons' wards of the newly-designated city hospitals, on the batteries and defensive lines protecting the capital, and in the city's numerous mills and shops upon which the Confederate government came to rely for 
outfitting and supplying its many soldiers and destitute civilians, consumed much of their time and energy. Among the ranks of the city's native elite, numerous of the most "respectable" men of Richmond found themselves called upon to serve in both the expanded local government and in the newly arrived Confederate government.

To add to the ladies' anxieties concerning the war's dramatic shift in both the size and preoccupation of the native male population, the endless incoming trains full of (often rowdy) soldiers, politicians, businessmen, slaves, and industrial workers overwhelmed the small, but powerful population of Richmond's elite male leaders. ${ }^{36}$ Worse yet, it threatened to completely dismantle the social and economic order established by the "respectable patriarchy" of the city upon which the ladies had always found meaning and their own esteemed social status. ${ }^{37}$

With the honor and power of their men thus under attack, and with their men so preoccupied by the politics and inner-workings of war, Richmond's ladies found themselves surprisingly alone as they struggled to reinforce the cherished moral and social order of old. ${ }^{38}$ Highly conscious of their Revolutionary heritage and their roles as "Republican mothers," Richmond's ladies simultaneously threw themselves into the patriotic work expected of them by supporting their men and their fledgling country through food and clothing donations, sewing circles, and local fundraisers. ${ }^{39}$ Their social burdens, they realized, must not interfere with their patriotic duties, but rather (in many instances) would have to supplement such duties. Thus,

\footnotetext{
36 Richmond Examiner, March 5, 1864.

37 Elizabeth Fox-Genovese, Within the Plantation Household: Black \& White Women of the Old South (Chapel Hill: University of North Carolina Press, 1988), 49, 203; See also, Stephanie McCurry, Masters of Small Worlds: Yeoman Households, Gender Relations, and the Political Culture of the Antebellum South Carolina Low Country (New York: Oxford University Press, 1997); Eugene Genovese, Roll, Jordan, Roll: The World the Slaves Made (New York: Vintage Books, 1976); Bertram Wyatt-Brown, Honor and Violence in the Old South (New York: Oxford University Press, 1986); Drew Gilpin Faust, Mothers of Invention: Women of the Slaveholding South (Chapel Hill: University of North Carolina Press, 1994); Thavolia Glymph, Out of the House of Bondage: The Transformation of the Plantation Household (New York: Cambridge University Press, 2008).

38 Faust, 230, 246; Wyatt-Brown, 190; Fox-Genovese, 49.

${ }^{39}$ Sallie Brock Putnam, Richmond During the War: Four Years of Personal Observation (New York: G.W. Carleton, 1867, reprint; Lincoln: University of Nebraska Press, 1996), 40; see also, Nina Silber, Gender and the Sectional Conflict (Chapel Hill: University of North Carolina Press, 2009).
} 
Richmond ladies proudly made their first small steps into the public sphere as both Confederate "patriots" and as the primary protectors of a beloved, but threatened, society. ${ }^{40}$

However, with every day that passed, more train cars and wagons packed with refugee women and children from all over the South arrived within the city limits, eventually outnumbering the native female population. This onslaught of refugees only expanded the ladies' severe apprehensions about the war's threats to both the politics and the respectable patriarchy that undergirded southern society. A majority of these incoming women were of the lower class - poor women in search of shelter from the invading Federal army and desperate for a clerkship in the Confederate government or any menial job in the city's many shops and businesses. The impoverished women packed into the city's hotels and dark, stuffy boarding houses and quickly proved themselves to be a frustrating burden upon the city's dwindling resources of food, shelter, and basic clothing. Depressed and desperate, many of these women took to the streets and to the bottle, selling their bodies to the city's female-starved soldiers and roughneck men in the numerous brothels and bordellos cropping up in seemingly every alley of the city. Much to the annoyance of the more respectable members of society, these lowly women often chose to pass their spare time by wandering through the downtown area in various states of drunkenness and engaging in altercations with men and women from every class. For example, on April 1, 1862, Mrs. Mary Jane Purcell, an older, Irish woman, was arrested on $18^{\text {th }}$ Street, near the old city market, for "being drunk and interfering with ladies and children," while on May 14, the Mayor scolded the prostitutes of Martha Coleman's "house of ill fame" for

\footnotetext{
40 Putnam, 39-40; see also, Stephanie McCurry, Confederate Reckoning: Power and Politics in the Civil War South (Cambridge: Harvard University Press, 2012).
} 
"openly parading in the principal streets of the city in a carriage with cream colored horses, dressed in men's clothing" and otherwise acting in an obscene and inappropriate manner. ${ }^{41}$

Simultaneously, Richmond's leading ladies grew increasingly anxious over the emerging challenges posed by members of their own social class as well. As the ranks of the upper classes swelled with the wives and daughters of newly appointed Confederate politicians and generals, Richmond ladies of the "old order" quickly realized that their beloved society was not only facing a threat from below, but that it also was under assault from the incoming tide of elite female refugees who immediately commenced vying with the native elite for social power and control. In turn, they drew strict social boundaries between themselves and the newcomersboundaries which only a pre-selected group of old friends from the Washington social circles were able to breach, provided their natural appearances and behavior ascribed to the tenets of Old Dominion society and to an evolving set of complex social rituals that dictated decorum among the elite. Many wealthy, incoming women readily embraced those rituals as a means to claim their own spot within the elite circle and, in turn, helped perpetuate the long-term use of such rituals in order to help their peers sort out social "pretenders" from true leading ladies.

The initial group of perceived upper-class "intruders" included such women as Mary Chesnut, Lydia Wigfall, and Varina Davis, but also included single refugees and respectable young ladies from outlying schools who flocked to the capital city from embattled areas of Virginia, and later, North Carolina, Georgia, and South Carolina. The proud women of Franklin and Grace Street and the quaint and historic "Court End" neighborhood feared that these well-todo newcomers might challenge their own long-respected places at the top of the social food chain. After all, the newcomers were not from Richmond, and many did not contain the sacred

\footnotetext{
41 Richmond Examiner, April 1, 1862, May 14, 1862; Thomas P. Lowry, M.D., The Stories the Soldiers Wouldn't Tell: Sex in the Civil War (Mechanicsburg, PA: Stackpole Books, 1994; repr. 2012), 70-72; Lowry, Sexual Misbehavior in the Civil War, 25-35; Putnam, 76-77.
} 
Virginia blood and bear the Virginia refinement necessary to achieve a place at the top of society. Although several proud, nostalgic women and many strong proponents of the "Lost Cause," such as Richmonder Sallie Putnam, would later write in their memoirs that the war was a "great social leveler," that "former distinctions were forgotten," and "old prejudice was laid aside in the universal interest felt in the events of the future," it is perfectly clear that protecting existing class distinctions and elite privilege, and maintaining some sort of social barrier between native Richmonders and the newcomers, were top priorities to most of the city's ruling ladies. ${ }^{42}$

However, despite the foreignness of the new well-to-do women and despite the feuding and back-talking that continued within the most privileged social sphere throughout the whole war, both the native and "foreign" female elite quickly realized that they certainly had more in common with each other than they did with the dross of poor and lowly women whose mass intrusions into the Confederate capital seemed endless. With the majority of these upper-class ladies seeking, more than anything, to preserve or regain their former, prime social status and to restore to their current society a proper and respectable moral order, this set of ladies ultimately conglomerated into a diverse, but loosely confederated group which I have termed the "capital elite."43

Although they stemmed from different geographical regions and "sub-cultures" of southern society, the women of the capital elite shared the important sensibilities of respectability and privilege, as well as a common understanding of morality that bonded them together in common cause and ideology. ${ }^{44}$ These women believed that it was in their own best interest, and in the long-term best interest of society as a whole, both to assume responsibility

\footnotetext{
42 Putnam, 39-41; Wyatt-Brown, 26.

43 Kimballl, 217.

44 Daniel Wickberg, "What is the History of Sensibilities?: On Cultural Histories, Old and New," The American Historical Review 112, no. 3 (2007): 661-684.
} 
over the social ordering of everyday life and to help their inferiors recognize the elites' right to social deference, wealth, and a "comfortable" life style. Such rights, they felt, derived both from their respectable bloodlines and thus from the hard work expected of them as the monitors and protectors of their social inferiors. ${ }^{45}$ Only under their inferiors' acceptance of their elite social privilege and responsibility could they maintain their traditional reign over society - a reign that, in turn, allowed them to govern the morals and order of the Confederate capital. Thus, the ladies concluded, just as they felt they owed the society that they governed a debt of honorable leadership, moral authority, and "protective" social guidance, so too did the "governed" owe them a debt of honor, gratitude, and allegiance in return.

But, what exactly did membership within the "capital elite" provide its ladies? Furthermore, how did one establish (or re-establish) oneself as a privileged member of the "capital elite" during such a time of chaos, confusion, and sacrifice? For both the established leading ladies and the incoming hopefuls, ritualized house visits with pre-selected ladies served as the proving ground for entry into the coveted inner circle of the new capital elite.

Visiting friends and neighbors in the nineteenth century was not only an everyday social occurrence; it also served as an important cultural ritual for middle and upper-class Victorian Americans who looked to the house visit as a way to legitimize their own high social standing among upper-class neighbors, but also as a means by which to create a sense of solidarity amongst the upper classes. Elite women did so by segregating themselves spatially and aesthetically from the lower classes and showcasing their wealth and privilege to both their social peers and the "lowly sort" during their highly conspicuous travels between friends' houses.

\footnotetext{
45 Genovese, Roll, Jordan, Roll, 4-5; McCurry, Masters of Small Worlds, 6; Steven M. Stowe, Intimacy and Power in the Old South: Ritual in the Lives of the Planters (Baltimore: Johns Hopkins University Press, 1987), xvii, 251.
} 
The ways in which a lady comported herself in public and amongst fellow respectable peers led to her ultimate acceptance or rejection from the innermost circles of the upper classes. ${ }^{46}$ The process of becoming a member of the Richmond capital elite and maintaining one's claims to such status thus was often fraught by a series of continuous negotiations and carefully crafted projections of an identity of "ladyship" that met both the traditional expectations of Richmond society and yet complied with the evolving necessities of wartime. Richmond women therefore relied upon the ritual of the house visit as a means to establish their membership within the capital elite, defend their rank within the upper echelon of society, and distinguish true "ladies" from newly arrived social imposters. Such differentiation was essential for these women to attain and maintain the social and moral authority to institute order over and provide models of ladylike respectability for the ever-diversifying and perceptibly devolving character of Richmond society as a whole.

As cultural historian Karen Halttunen notes in her seminal work on the culture of social performance in nineteenth-century America, women's mere movement along the public avenues of a city itself served as an important ritual through which ladies sought to distinguish themselves from “lesser" women. Quoting a mid-nineteenth century manual on ladies' etiquette, Halttunen notes that, "A lady's conduct is never so entirely at the mercy of critics...as when she is in the street. Her dress, carriage, walk, will all be exposed to notice; every passerby will look at her, if it is only for one glance; every unlady-like action will be marked; and in no position will a dignified lady-like deportment be more certain to command respect." ${ }^{, 47}$

However, as Halttunen also argues, the rapid growth and industrialization of cities during this time due to capitalism, combined with the ensuing increase in strangers, manipulative

\footnotetext{
46 Haltunnen, 93, 96.

${ }^{47}$ Qtd. in, Confidence Men and Painted Women: A Study of Middle-Class Culture in America, 1830-1870 (New Haven: Yale University Press, 1986), 114.
} 
confidence men, and seductive painted women roaming the burgeoning cities, caused considerable anxiety for Americans who formerly had been accustomed to knowing the character and class of everyone in their tight-knit communities. Such anxiety only grew during the Civil War, especially in the major urban hubs. Many Americans grew wary and suspicious of strangers. They feared that they could neither trust the newcomers to their cities, nor could they truly know a person's real character due to the "social masks" that the new population seemed to be donning in order to make a name for themselves, both socially and economically, in an increasingly competitive and zealous society. ${ }^{48}$

The home visit thus served as a sanctuary from the bustle and danger of the outside world where friends and neighbors could gather in the solidarity and support of more "sincere" and moral character and get acquainted with each other in a safer and more "truthful" setting. Women especially— the guardians of domestic purity—relied upon house visits to ease their minds and to help inculcate respectability, character, and lady-like behavior among their fellow social and moral arbiters of society. According to Sallie Putnam the "hospitable walls" of her friends" homes in Richmond "provided security" from the flood of "pernicious characters, speculators, gamblers, spies, and bad characters of every grade" who "flocked to the capital" during the war, engaging in nightly thievery, garroting, murder, and debaucherous acts. ${ }^{49}$

Distinguished Maryland belle and refugee, Constance Cary, lauded the ritualistic gatherings at the homes of the city elite as critical promoters of upper-class solidarity and respectability, as well as inculcators of "proper" moral order during the bloody and chaotic Fall of 1862: "Society was reinforced by a number of agreeable and high-bred women from all parts of the South, who had previously graced the wider social spheres of Europe and America," Cary

\footnotetext{
48 Haltunnen, 20, 24, 57.

${ }^{49}$ Putnam, 76-78.
} 
wrote. Interestingly, Cary noted in particular that part of the "peculiar attraction" of these gatherings lay "in [their] total absence of pretense....People thus bound by a common tie of interest and poignant sympathy tolerated no assumption of superior fashion in any of their number. In such an atmosphere flourishes best the old fashioned grace of neighborliness." This particular passage in Cary's memoirs appears to have seen strongly influenced by Cary's own post-war nostalgia. Whether her elite friends were truly "bound by a common tie of poignant sympathy" and forbid the "assumption of superior fashion" or not, the fact that Cary went out of her way to paint the home visits in this particularly rosy light reveals her perceived need to do so. Perhaps Cary thought such a positive portrayal was necessary in order to justify such frequent social gatherings during the war to her critics in the postbellum era. Or, perhaps Cary so badly wanted to believe in the justness and positive influence of her peers' wartime actions that she convinced herself that such gatherings truly were a necessary reinforcement and celebration of elite privilege and respectability, and that they lacked the distasteful "aristocratic" pomp or flashiness that she knew the public disdained. Whatever her reasons for penning this particular observance as she did, Cary's description ultimately reveals that a vital component to attaining social prowess was the achievement of tasteful indulgence - an achievement that, whether or not she or her peers could truly boast of it, was continuously sought through house visits and informal social gatherings. ${ }^{50}$

Cary went on to praise the good taste and congeniality of the gatherings, but also highlighted further the importance of such house visits as essential amalgamating and bonding experiences for the upper class. Specifically, she noted that the visits played a critical role in bolstering both the physical and emotional comforts of her fellow lady friends:

\footnotetext{
50 Mrs. Burton Harrison, Recollections Grave and Gay (New York: Charles Scribner's Sons, 1911), 94.
} 
To the very last, each refugee family shared what it had with the other, while Richmond folk threw open their broad, delightful homes to receive their friends, with or without gastronomic entertainment, lent furniture to those in need, and sent dainty little dishes to the sick. All rejoiced in each other's joy, grieved with each other's griefs. Hardships in such company were lightened of their weight. Sorrows so shared were easier to bear. ${ }^{51}$

Again, though these comments might exaggerate the wholesome generosity of the elite toward their newly arrived peers, and thus might not accurately reflect what actually transpired during these gatherings, Cary's comments reveal that these informal social events were intended and perceived (by Cary herself) to have relieved the struggles of upper-class Richmonders and refugees such as Cary whose fortunes had been altered by the war. In sharing their wealth with newcomers and friends-in-need, the gatherings perpetuated familiar social traditions befitting those women who were accustomed to a life of comfort and privilege. The house visits also provided a key forum in which Richmond's landed ladies could conspicuously fulfill their social responsibilities as guardians and promoters of the treasured, traditional tenets of the "old fashioned grace of neighborliness." Thus, such gatherings enabled the city elite to showcase the important qualities of generosity and hospitality that affirmed their position as social queens and moral arbiters before the eyes of strangers.

For distinguished women such as Mrs. Virginia Clay, wife of Alabama Senator Clement C. Clay, visiting the houses of various distinguished women served as a ritual of reunion for what Clay perceived to be the "royal court" of high society that reigned over Washington, D.C. prior to the war. This "court" had consisted of top-ranking men and women from all over the country who had relied on each other for company and comfort during their temporary stay in the nation's capital. Although these leading ladies came from different regions, a shared desire for social interaction, prowess, and even mere entertainment had united the women into a tightly knit

\footnotetext{
51 Harrison, 94.
} 
group of friends. Having previously enjoyed the amalgamating dinners and balls in the nation's capital that were hosted and attended by some of Washington's foremost politicians and their leading ladies, women such as Virginia Clay looked to house visits in Richmond with some of her former society sisters as a way to re-establish authority over the social scene of her temporary new community in the Confederate capital.

However, one's acceptance into another's home, and thus into the "privileged" sphere, depended heavily upon both one's material projection of morality, sincerity, and respectability, as well as one's broader reputation within the community. Sincerity and good character certainly reigned supreme as the most revered personal traits a woman could possess. However, respectable society at its core lay rooted in a carefully sculpted set of social projections. As part of these projects, respectable society members, both male and female, were expected to conform to a widely-accepted core of cultural "scripts," or social codes, with which any member of the upper classes would have and should have been familiar. As evidenced by the writings of T.C. DeLeon and his contemporaries, Civil War Richmonders made numerous references to their Revolutionary heritage and their pride in the city's customs of social engagement and leadership that stretched back approximately 100 years. ${ }^{52}$ Such references reveal Richmonders' reliance on a traditional, long-standing social culture of performance in which genteel women (and men) interacted with each other through symbolic aesthetics, manners, and speech that would ultimately prove or disprove their social prowess and power before both their peers and their inferiors. $^{53}$

\footnotetext{
52 Putnam, 40; DeLeon, 51; Judith McGuire, Diary of a Southern Refugee During the War, by a Lady of Virginia (New York: E.J. Hale \& Son., 1867; reprint, Lincoln: University of Nebraska Press, 1995), 176, 178; Gregg D. Kimball, American City, Southern place: A Cultural History of Antebellum Richmond (Athens: University of Georgia Press, 2000), 8-9.

53 For a more in-depth treatment of these long-standing social customs, see, Rhys Isaac, The Transformation of Virginia, 1740-1790 (Chapel Hill: The University of North Carolina Press, 1982), 323-357.
} 
For both the native ladies of Richmond who sought to re-affirm their social standing before the newcomers of society and for the elite refugees who hoped to break into the coveted inner circles of the native upper classes, the successful execution of such cultural prescriptions was essential. $^{54}$ By not subscribing to those social and cultural codes, a lady set herself dangerously apart from the rest of her peers and risked social alienation altogether. Such alienation was clearly evidenced by Mary Chesnut's brusque write-off of Mrs. Memminger, wife of the first Confederate Secretary of the Treasury, Christopher Memminger in the early days of the war, when (for reasons unknown) she refused to pay any visits to the newly arrived Confederate First Lady, Varina Davis. “There is manners for you, and knowledge of proper etiquette!" Chesnut huffed. ${ }^{55}$

Fortunately for Mrs. Clay, her long-cultivated friendships with some of the foremost members of Richmond's capital elite enabled her to meld into Richmond's high society much more easily than other women who had not been members of the antebellum Washington court. Upon her arrival to Richmond in the fall of 1861, Mrs. Clay exclaimed in her memoirs that, "I almost imagined myself in Washington" amongst "so many dear friends." She immediately took up residence at the chic Spotswood Hotel, located on $8^{\text {th }}$ and Main Streets, alongside fellow distinguished ladies, Mrs. Stephen Mallory and Mrs. Joseph Johnston, and became a frequent guest at the new home of Jefferson and Varina Davis on $12^{\text {th }}$ and Clay Streets. ${ }^{56}$

One of the more active members of Richmond's social scene, Virginia Clay was ever conscious of the need to "keep up" with her friends in style and dress in order to maintain her place within the upper echelons of society. Prior to departing for Richmond that autumn, Mrs.

54 Wyatt-Brown, 14.

55 Chesnut, 571.

56 Virginia Clay-Clopton, A Belle of the Fifties: Memoirs of Mrs. Clay, of Alabama, Covering Social and Political Life in

Washington and the South, 1853-66 (New York: Doubleday, Page \& Company, 1905), 167. 
Clay's personal maid had refused to pack more than two evening dresses, commenting, "We are going to war, we shall have no need for velvet or jewels. We are going to nurse the sick, not to dress and dance." However, much to Mrs. Clay's relief, one of her closest domestic slaves named Emily refused to let her mistress depart for the Confederate capital without the proper attire fit for her social position. Re-packing Mrs. Clay's trunk with numerous ball gowns, Emily huffed that there was “bound to be somethin' goin' on [in Richmond], and I ain't goin' to let my Mistis be outshined by...dem other ladies.” Mrs. Clay later expressed her deep gratitude at Emily's foresight, noting earnestly that she had "heroes to dine with and to cheer, both civil and military, and somber garments are a sorry garb in which to greet or brighten the thoughts of men tired with the strain of building or fighting for a government." ${ }^{57}$ Mrs. Clay appears to have considered it both a social entitlement and a responsibility to grace these refined social functions with her presence and that, in doing so, she contributed to a sense of community among the Richmond elite and helped to lighten the mood of the Confederate capital and its celebrated leaders.

While Virginia Clay saw the unquestionable socio-political merit and necessity of perpetuating the illustrious house visits and informal gatherings of the antebellum Washington days, she simultaneously seemed aware of the need to tone down the nature of her own such socializations in light of the moral dictates of war, in order to be fully reaccepted into the inner circles of the capital elite. Mrs. Clay initially proved successful in this regard, but ultimately fell victim to the temptations and longings for her former Washingtonian extravagance by the latewar period. However, in the early days of the war, like Constance Cary, Mrs. Clay praised the leading ladies' good judgment and taste in appropriately scaling back the Washingtonian lavishness of such entertainments and of the finery sported at the events, in light of the war. Of

57 Clay-Clopton, 169. 
the gatherings she gushed, "A sororal spirit actuated our women, and while our greatest entertainments missed some of the mere display which had marked the social events in the Federal city, they were happier gatherings, for we were a people united in interest and in heart. Some of the brightest memories were informal evenings where neighbours gathered sans ceremonie." $" 58$

Certainly the inner moral compass of the capital elite would have told them that overly lavish dress and gatherings would be inappropriate during a time of war. However, considering that Richmond's capital elite operated within a society in which leadership lay rooted not only in a demonstration of cultural authority from above, but also in garnering the deference of those below them, it would be nearly impossible to assume that their actions did not take into consideration the opinions of the broader public. The critical gaze of both middling and lowerclass Richmonders and the elites' more sober-minded peers certainly demanded a retreat from the carefree indulgences of the Washington years. Luckily for the well-established and highlyrespected Virginia Clay, she needed only to slightly temper her familiar social customs and behaviors in order to regain her foothold among the leading ladies of society.

However, for some lady refugees from Washington society, such as former Alexandria resident, Judith McGuire, whose husband worked as a clerk in the Confederate Postmaster's Office and then later as a hospital chaplain, breaking into the coveted circles of the capital elite proved much more challenging. Arriving in Richmond in early February of 1862, McGuire experienced great difficulty merely in securing a place to live inside the crowded capital city. McGuire had been born into a prominent Virginia family with direct ties to Richmond's elite society. In fact, Judith's cousin had built the Brockenbrough mansion on $12^{\text {th }}$ and Clay Streets that served as the Davis family residence during the war, and both the distinguished McGuire

58 Clay-Clopton, 169. 
and Brockenbrough families owned several large, prosperous plantations throughout Virginia. However, despite her family lineage, and despite having married well, McGuire was surprisingly denied a room at the house of one wealthy Richmonder who claimed that she was "far too rich" to take on boarders, even of McGuire's class. Naturally, McGuire longed for a room within one of the larger, fine houses in the city that was more suited to her social status; however, necessity drove her to resort to begging a middling landlady for a room in exchange for McGuire's promise that her Reverend husband would spend a portion of each day saying prayers for the family at the house. ${ }^{59}$

Ultimately, even McGuire's humblest begging efforts could not win her a room within this particular house, as the exorbitant cost of the rooms ultimately forced her to accept a much smaller room at the unassuming house of a friend on Grace Street. ${ }^{60}$ Although some of her former friends among the capital elite eventually invited her to a few social gatherings during the first two years of war, the ever-pious McGuire came to feel strangely alienated and out of place in that social circle by the winter of 1863-64. Ultimately, she chose to replace her own fine dresses with plain calico and homespun, and decided to devote most of her time to religious pursuits, aiding the wounded at the local hospitals, and participating in the sewing circles led by industrious, patriotic women of the middling classes. ${ }^{61}$

Though initially convinced that all of Richmond's women, from high to low, had been united in heart around the Confederate cause and were perfectly willing to forsake most former luxuries and finery for the sake of their soldiers, widows, and orphans, McGuire gradually began to realize the differences in attitude and behavior between the "true" capital elite and the

\footnotetext{
59 McGuire, 87-9.

60 McGuire, 88, 89, 90, 92; 252, 300, 302.

${ }^{61}$ McGuire, 187, 196, 217.
} 
formerly wealthy members of the upper and middling classes. ${ }^{62}$ Apparently, if a woman could not definitively prove that she was completely committed to upholding the privileges and social practices of elite ladyship, and if her conceptions of social responsibility differed from that of the leading ladies, she could not expect to win a place among the capital elite. The leading ladies' lofty and rigid standards for admission into their inner social circle represent one of their many blind spots to the negative influences of their social behaviors. Unable to grasp that such a rigid approach to social acceptance in fact might alienate many more women than it might impress (and thus might undermine the very camaraderie and authority that they so desperately sought to attain), the ladies often crippled themselves, socially, through such mental entrapment in modes of thinking and perceiving that were often inflexible. Although the "true" capital elite had chosen to tone down some of their former traditions of social extravagance and indulgence, a place within this coveted inner circle of social rulers still required a level of wealth, material distinction, and an active social life which McGuire simply could not afford to maintain and which she thought was inappropriate during the late war.

Refusing to live in the crowded and over-priced boarding houses in downtown Richmond, she moved to a small cottage in Ashland, twenty-five miles north of Richmond, for about ten months where she continued to care for the wounded and knit socks and other clothing for the soldiers with eight other housemates. ${ }^{63}$ She also humbly opened her own soap-making business that helped to support her and her family throughout the war years. ${ }^{64}$ McGuire felt that it was horribly unjust that fine families from Alexandria, Fredericksburg, and beyond were now reduced to "damp basement rooms in Richmond." She wrote of one family of former luxury who resided in the dark basement of a city boarding house, the daughters being forced to do all the

62 McGuire, 178, 23.

63 McGuire, 202, 240.

64 McGuire, 196. 
cooking and washing, and the father bed-ridden by illness. Another formerly distinguished family was now reduced to a mother and four daughters, whose only income came from one daughter's job as a note signer in the Confederate Treasury. McGuire lauded the fact that the country houses outside Richmond were "remarkably elastic for refugees," and wistfully wrote that if only the "city people would do more in that way, there would be less suffering."

In October of 1863, McGuire received yet another blow to her morale when she returned with her husband to Richmond and was forced to accept a clerkship in the Confederate Commissary Department in order to help pay for their lodgings. Upon relocating back to the city, the McGuires had searched everywhere for a decent place to live in the city. However, much to Judith's embarrassment, they ultimately were forced to take up residence in a solitary, small, bare-floored partition of a room in the old Brockenbrough family home, where Judith's father had once lived. Relegated to the position of lowly boarders in what had once been the Brockenbroughs' seat of power in Richmond, the McGuires lived out the rest of the war as two of many refugees packed into the family home, now owned by a Mrs. "R." Fortunately for McGuire, her dear friend, Mrs. Mallory, wife of the Confederate Secretary of the Navy, refused to desert her in her time of need and brought her a carpet for her room. ${ }^{66}$

However, still hoping to regain at least some shred of dignity, McGuire refused to abandon the search for her own, private set of rooms in a less populated Richmond home. With every house now packed to capacity with boarders, McGuire wandered the city streets for months in search of a new, more distinguished shelter. Feeling like even more of a social outsider than ever before, Judith McGuire sadly reflected, "I often thought how little possessors of luxurious homes of Richmond know of the difficulties with which refugees are surrounded

\footnotetext{
65 McGuire, 172-3.

66 McGuire, 241-4.
} 
and how little we ever appreciated the secure home feeling which we had all enjoyed before war.",67

As she made the rounds in search of her new home, she was greeted only by boarding houses filled with damp basements, rheumatism, enormous rental prices, and depressing darkness. Her own dimly lit, solitary room in the old Brockenbrough house, with no kitchen access, and only a small stove on which to cook her meager dinner, caused McGuire great shame and despair. While walking, defeated, back to her room one evening, McGuire gazed into the many elegant homes along Franklin Street and reflected on the divide that had clearly arisen between herself and her former friends:

I looked in as I passed and saw cheerful countenances collecting around center tables or sitting here and there on handsome porticoes or marble steps to enjoy the cool evening breeze---countenances of those whose families I had known from infancy and who were still numbered among my friends and acquaintances. I felt sad, and asked myself if those persons could realize the wants of others, would they not cheerfully rent some of their extra rooms? Rooms that were once opened on grand occasions are now, as such occasions are few and far between, opened not at all for weeks and months together. ${ }^{68}$

The frustrated and disappointed McGuire simply could not comprehend how she had somehow become the outcast of this familiar society, nor how such former friends could now care so much more for themselves and their own social prominence than they did for their peers. Baffled, McGuire questioned, "Would they not cheerfully remove some of their showy and fragile furniture for a time and allow those who had once been accustomed to as large rooms of their own to occupy and take care of them?" In her mind, such hospitality would be "no object" to them, and surely their "kindness would be twice blessed" if they chose to give to the refugees some comfort and happiness, or apply their money to the "wants of the soldier or the city poor." Such actions, McGuire, believed would, in fact, be good for their souls, as well as for the

\footnotetext{
67 McGuire, 300.

68 McGuire, 301-302.
} 
swelling class of refugees, by rewarding those living in comfort with "the luxury of doing good as well." McGuire firmly believed that, by sharing some of their wealth, "[t]hey would then find that the quality of mercy is not strained, but that it would indeed like the gentle dew from heaven fall into their very souls and diffuse happiness which they know not of. ${ }^{69}$

McGuire's plight represented the worst fears of the capital elite. To experience such a fall from grace would feel like social suicide. As historian Joan Cashin notes, the refugee experience for all women — but admittedly, to varying degrees — was filled with physical, mental, and social danger and the chance of "catastrophic loss." Cashin points out that, luckily for many women of the capital elite, their "social and political status acted as a buffer from the worst of the refugee experience." ${ }^{, 70}$ In order to avoid such a tragedy, Richmond's ladies grew increasingly more introspective about how they might ensure the permanence of their own social prowess, which often involved the best possible preservation both of their traditional household and of key elements of material culture that reminded them and any observers of their illustrious family history. Many ladies believed that, by flaunting their distinguished family history, they might, in turn, help to "ward off shame, prove respectability, and make refugee life more bearable.".71

Famed South Carolina diarist and refugee Mary Chesnut wrote perhaps some of the most detailed commentary about her self-consciousness in trying to maintain her elite social status while not incurring the disapproval of others - commentary that provides a significant window into just who could become a member of the capital elite and how they could maintain such status. One of the most active "social butterflies" of Civil War Richmond, Mary Chesnut initially established herself in the Spotswood Hotel among her high-class female peers and wrote

\footnotetext{
${ }^{69}$ McGuire, 302-4.

70 Joan Cashin, “Into the Trackless Wilderness: The Refugee Experience in the Civil War," in A Woman's War: Southern Women, Civil War, and the Confederate Legacy, Museum of the Confederacy Series (Charlottesville: University Press of Virginia, 1996), 29, 36.

${ }^{71}$ Cashin, "Into the Trackless Wilderness," 41.
} 
extensively about her various visits to the rooms and homes of Richmond's most illustrious residents. Immediately, she began recording conversations overheard from both her fellow ladies and from the outside public in which critics discussed the style of dress, manner, and the comings and goings of the ladies in exhaustive detail.

By all accounts, one of Richmond ladies' most favorite targets of social criticism was Mrs. Jefferson Davis herself, who, like many other newly relocated ladies, struggled throughout the war to fulfill the rigid expectations that her peers held for her regarding her appearance, behavior, and social responsibilities . As Mary Chesnut flitted about the various social retreats in the city, she learned vital lessons about the importance of parlor chats and teas in making or breaking one's reputation, and she became even more aware of the need always to dress and comport oneself in public as if one was the main player in an elaborate social performance staged before the eyes of high and low society alike.

Chesnut's accounts of the struggles of Varina Davis, in particular, highlight the demanding expectations and high standards of the well-established Richmond elite in accepting new members into Richmond's reigning social circle. Natural beauty, a noble bloodline, grace, self-awareness, tasteful elegance, social tact, patriotism, and delicacy seem to have defined the cultural prescriptions for ladyship in wartime Richmond. The competitive and carefully discerning nature of the city's leading ladies made social acceptance an on-going process of negotiation for unfortunate women such as the Confederate First Lady whose appearance, personality, and natural comportment did not always match her peers' high expectations. As early as June, 1861, after a long carriage ride to the soldier's camps on the outskirts of Richmond to visit some friends, Mary Chesnut was struck by some ladies' vitriolic talk about Varina. Accompanied by 43-year-old Charlotte Wigfall, the wife of the Texas Senator, Louis T. Wigfall, 
Chesnut reported that Wigfall filled the entire ride with "gossip from the Spotswood" Hotel, ${ }^{72}$ a large portion of which centered around Varina Davis. Charlotte continued her rant against Varina in a letter to her son, Halsey, writing that, “I don't think Mrs. Davis improves much our acquaintance; she has some good qualities, but many very objectionable ones."73 By the end of that summer, Charlotte and her good friend, Lydia Johnston (the wife of General Joseph E. Johnston), had developed such a disdain for the First Lady that they had even begun referring to Varina as a crude and "coarse Western belle."74 Although it is likely that her husband's rocky relationship with President Davis fueled much of Mrs. Johnston's personal bitterness toward Varina, Mrs. Johnston wasted no time in latching on to Varina's most objectionable and "unladylike" features as grounds for her fervent critiques of the First Lady.

Unfortunately for Varina, her natural, largely unalterable appearance and mannerisms simply did not align with the social expectations of some of the most influential members of the coalescing capital elite. Other leading ladies of Richmond appeared to be obsessed with criticizing Varina for her olive, "nearly-mulatto skin," unusual height, "overly-commanding" and almost "masculine" appearance as compared to the pale, frail, classically beautiful belles of Richmond. ${ }^{75}$ Additionally, the majority of Richmond's leading ladies originally hailed from the eastern portions of the Confederacy, and they frequently demeaned Varina for her visibly western, Mississippi delta origins. Marion Myers, the wife of the Confederate Quartermaster General, even went so far as to call Varina a "squaw" for her dark appearance and "wild" personality. $^{76}$

\footnotetext{
72 Chesnut, 87.

${ }^{73}$ Charlotte Wigfall, letter to Halsey Wigfall, 11 June, 1861, Family Papers of Louis T. Wigfall,1858-1909, box 1, Library of Congress (Washington, D.C.).

74 Chesnut, 139.

75 Cashin, First Lady of the Confederacy, 112.

76 Bell Irvin Wiley, Confederate Women (Westport, CT: Greenwood Press, 1975), 100.
} 
During several visits to her friends' drawing rooms and intimate tea parties in July of that year, Mary Chesnut also recorded numerous conversations in which the women mocked and scorned the First Lady, Varina Davis for acting too "queenly," and even took aim multiple times at the circle of women who often appeared at her door for teas and visits. These women lambasted "Mrs. D.'s ladies" who "are not young, and are not pretty."77 Chesnut learned that both men and women spoke ill of Mrs. Davis and that although many of them found her to be a charming conversationalist, there were many who "call Mrs. Davis the Empress and do not like her. The notorious A.D. Banks abuses her most of all—says she is so killingly patronizing." ${ }^{\circ 8}$ Meanwhile, Chesnut observed that many elite women thought Varina to be actually quite fat and spread rumors that she wore a red wig and "mock jewels" to perpetuate her image as "Queen of the Confederacy." In fact, she noted that, by 1864, "it was the regular thing at the Spotswood to tell people that Mr. and Mrs. Davis said dreadful things of them when Mr. and Mrs. Davis hardly knew of the persons so abused at all.,"79

Evidently, if Richmond's landed ladies judged one's behavior to contradict or even slightly diverge from the social and cultural scripts assigned to an elite southern lady, one's acceptance into ranks of the city's social queens proved nearly impossible. At one particular dinner, one jealous woman critiqued Varina for her "overly-flirtatious" manner with the men who seemed so preoccupied by her that they ignored the mob of beautiful belles gathering around them, remarking, "Heavens! If only we had ships of war whose aim was as sure and as deadly as those pointing to Mrs. Davis and Mrs. Clay." $" 80$

77 Chesnut, 91.

78 Chesnut, 429.

${ }^{79}$ Chesnut, $747,95,609$.

80 Chesnut, 85, 325, 559. 
Although a dear friend of Varina, even Constance Cary Harrison admitted, in her Recollections, that Varina was "not always sparing of witty sarcasms upon those who had affronted her," ${ }^{81}$ which occasionally earned her the reputation of being "too well-educated" and "too blunt." A2 Although she knew that "flouting society's codes meant social death," unwaveringly unique sense of humor and impersonations of others were looked down upon by her peers, and several Richmond ladies thought it quite distasteful that the "unfitness of things" could provoke her to extreme and raucous laughter. Secretary of the Navy Stephen Mallory called Varina's "sense of the ridiculous perfectly riotous," and other elite women remarked that Varina's overall character appeared crude because of her "lack of self control." Although she was considered by many to be "brilliant," she was sometimes scorned for being unrefined, and it was thought that she gave the "Cotton people in Richmond a shock." 84

Unsurprisingly, Varina struggled throughout the war with her despair over her fragile social position. Varina herself constantly questioned her own ability to navigate the social waters of the Confederate capital. She often felt that no one understood her or appreciated her dry wit, her many references to literary figures, or her ability to hold her own in political conversations with Richmond's leading men, and she was largely right. Mary Chesnut eventually told her to refrain from "drollery or dry wit" altogether in public society, or people would gossip, and that no matter "how outlandish" her jokes might be, Richmonders were "so humorless" that they would treat quite literally every word she said. ${ }^{85}$

Varina longed to fit in with all of her elite peers and to enjoy the both the full social power and broader influence that they appeared to hold over both high and low society. In

\footnotetext{
81 Harrison, 127.

82 Cashin,114.

83 Betty Boyd Caroli, First Ladies (New York: Oxford University Press, 1987), 46.

${ }^{84}$ Cashin, 113.

85 Cashin, 131-133.
} 
November of 1864, Varina lamented to Mary Chesnut about the miserable condition into which Richmond society had fallen due to the myriad political and social pressures of the war: "Scandal is rife here," she wrote, "God forbid I should repeat such black reports as I was treated to a few days ago. Girls and women are the victims — and to tell you the truth, I think the most of it is told over campfires by idle men." She continued candidly to grieve to Mary that she felt as if her Richmond peers had killed her spirit, and that the only way to proceed was to numb herself to her surroundings and take pleasure in the kindnesses of the very few. Yet, although "her people" had slain her spirit, she still tried to find ways to love them. Desperately searching for some redemptive qualities in the women of Richmond who had caused her so much misery and anxiety, Varina wrote drily that, "the people no longer snub me, as it was only while the Lion was dying that he was kicked — dead he was beneath contempt. Not to say I am worthy to be called a lion —nor are the people here asses. Only I mean that I am so forlorn that they do not tell me how forlorn they think I am but are kind, and some are even affectionate—-for which I thank them. ${ }^{, 86}$

Varina's constant negotiation with her critics for social acceptance and authority serves as a microcosm of how she and other more controversial women fought continuously to achieve and retain a place within the inner circle of the capital elite. Despite her inability to conform in all respects to the cultural and social codes and ladylike expectations to which her peers so faithfully subscribed, Varina did her best to employ the social methodology adopted by her enemy, Lydia Johnston, that "a wise woman uses her foes as well as her friends for her own purposes. ${ }^{97}$ To that end, Varina remained outwardly pleasant, cordial, and dedicated to her social peers, writing to a friend after the war that "though they slay" her, yet she "trusted in

\footnotetext{
${ }^{86}$ Chesnut, 674.
}

87 Chesnut, 729. 
them" still. ${ }^{88}$ Well aware that informal house calls and parlor chats appeared to be the key forum in which a woman's reputation and social position could either be instantly elevated or dangerously tainted, Varina continued to court even her most sharp-tongued critics with invitations to teas and breakfasts.

Although Mary Chesnut had her own negative feelings about Varina early on in the war, she ultimately became one of Varina's biggest supporters and admitted that she was one of “Mrs. D.'s ladies," although the "truthfulness" behind the critics' comments "did not alleviate the bitterness." ${ }^{89}$ At the outset of the war, Chesnut had carefully sorted through her own mix of emotions regarding Varina's "rough" and "western” Mississippi breeding, and had, in turn, heavily questioned Varina's ability to serve as a successful First Lady of the Confederacy. Battling between the incessant negative commentary about the First Lady and her own natural inclinations toward Varina, Chesnut wrote that, upon listening to another woman "who slandered Mrs. D.'s republican court of which we were honorable members by saying we were not young, wore gaudy colors, and dressed badly," Chesnut "took an inventory of her charms" that reveals Chesnut's conflicting feelings toward Varina: "She is darkly, deeply, beautifully freckled. She wears a wig kept in place by a tiara of mock jewels... and wears black bead bracelets."90 Mary Chesnut clearly recognized that Varina's "unseemly" dark skin and excessive jewelry put her at risk for social mocking; however, upon applying the same critical eye to the Confederacy's First Lady that others did, nearly to the point of obsession, she found Varina to be quite charming. Chesnut's final evaluation of the First Lady found Varina to be uniquely beautiful, engaging, independent, but fiercely devoted to fulfilling society's numerous expectations of her as the First

\footnotetext{
${ }^{88}$ Mary Kimbrough, letter to Mrs. N.V. Randolph, April 26, 1915, Eleanor S. Brockenbrough Library, Museum of the Confederacy (Richmond, VA).

${ }^{89}$ Chesnut, 85, 91.

90 Chesnut, 95.
} 
Lady. As a result of her more thoughtful analysis of Varina's character, Chesnut's estimation of Varina far exceeded that of many of her friends.

Unsurprisingly, several of Varina's social enemies who sought to bar her from full acceptance into the capital elite were the wives of generals and politicians whose relationship with President Davis had become strained over the course of the war. Following a carriage accident during the summer of 1861 involving Varina and Lydia Johnston, and compounded by several heated disputes between General Joseph Johnston and President Davis, Lydia Johnston began a life-long fixation with excoriating Varina for her so-called un-ladylike behavior, "pretensions to royalty," and her less-than-belle-like appearance. Johnston's hatred toward Varina for flouting the social codes of true southern ladyship highlights the potentially disastrous social risks that upper-class Richmond women constantly faced if they dared to deviate from their assigned social and cultural roles. During a short visit to Chattanooga, Tennessee in January of 1863 , Mrs. Johnston went so far as to spread rumors that Varina was actually a Unionist at heart, and that her good friend from Washington, Mrs. Margaret McLean, who had recently been down to Chattanooga to "reportedly see me [Mrs. Johnston]" was actually a spy sent by the Davis family, and that her visit convinced Mrs. Johnston that Varina was indeed a "very smart woman...and a dangerous one."91

Varina's struggles continued in the ensuing years of the war, when, even in May, 1863, Mrs. Johnston referred to Varina in a letter to Charlotte Wigfall as the "Lady Queen" and lambasted the "finery being sported" by Varina during the height of war. ${ }^{92}$ In a particularly vitriolic letter to Charlotte Wigfall in August of the same year, Lydia bristled, "I am told Mrs. D.

\footnotetext{
91 Lydia Johnston, letter to Charlotte Wigfall, January 19, 1863, Family Papers of Louis T. Wigfall, box 3, Library of Congress (Washington, D.C.).

92 Lydia Johnston, letter to Charlotte Wigfall, May 17, 1863, Family Papers of Louis T. Wigfall, box 3, Library of Congress (Washington, D.C.).
} 
attributes her scarcity of friends to the influence of you and me" but that it was "not to be [made public] as 'Jeff needs both of their husbands."' Lydia went on to rage about the President's injustice toward her husband and his military career, but concluded her letter with a particularly bitter incrimination of both the President and his wife, who, Lydia believed, had to have helped poison the President against her husband:

I ought not to talk of this creature [Jefferson Davis], it arouses such a bitterness within me and disgust that I ever should have cared for him—which I certainly once did. I feel now nothing can ever make me forgive either of them when I looked last my dear old husband's gray head and care worn face...I could almost have asked God to punish them [Varina and Jefferson Davis], how happy I was until I knew him [Jefferson Davis]... it is not this war, that has broken up my home, and almost my heart, but the regime of one wicked man, and oh to think three years ago how I felt when I was losing my home and family...I was henceforth to be miserable. ${ }^{93}$

Despite the forceful accusations of Lydia Johnston and others against Varina, Mary Chesnut decided in the late summer of 1861 that the social benefits of affiliating with the somewhat controversial First Lady and her husband far outweighed the risks. Chesnut quickly overcame any doubts she had about the First Lady, as well as her own scrutiny of Varina's appearance and spicy humor and wit. And so, Chesnut concluded,

Once and for all, let me say-Mrs. D. has been so kind to me-I can never be grateful enough...She is so clever, so brilliant indeed, so warmhearted and consecrate toward all who are around her. After becoming accustomed to the spice and spirit of her conversation, away from her things seem lame and tame for a while. ${ }^{94}$

Interestingly, Chesnut's unflinching support of the First Lady from that point forward coincided with her pledge of allegiance to the Confederate President as well. By the end of that summer, Chesnut proudly declared,

\footnotetext{
93 Lydia Johnston, letter to Charlotte Wigfall, Aug 2, 1863, Family Papers of Louis T. Wigfall, box 3, Library of Congress (Washington, D.C.).

${ }^{94}$ Chesnut, 62, 109, 429.
} 
We may be flies on the wheel. We know our insignificance. But Mrs. Preston and myself have entered into an agreement — our oath is recorded on high. We mean to stand by our President and stop all faultfinding with the powers that be - if we can, where we can - be they general or cabinet members---magnanimous, if we are feeble! ${ }^{95}$

In the ensuing months, the now wholly loyal Chesnut tried to combat Varina's poisonous social critics and fight for the First Lady's permanent membership within the capital elite.

Chesnut continued to more openly laud what she viewed as Varina's most important qualities as a leading lady: Varina's true kindness and an undying devotion to her friends. Following one particularly enjoyable luncheon at the Confederate White House, Chesnut glowed,

I lunched at Mrs. D.'s, everything nice to eat and I was ravenous. Yesterday I was forced to dine on cold asparagus and blackberries, so repulsive. She was as nice as the luncheon. When she is in the mood, I do not know so pleasant a person. She is awfully clever - always.... Mrs. D.'s drawing room...was brilliant, she was in great force. ${ }^{96}$

Fortunately for the First Lady, despite her detractors, the personal appeal of both Varina herself and her illustrious drawing room attracted the much sought-after support and admiration of Richmond women who fell just below the official plane of the Richmond elite. Native Richmonder and member of the upper-middle class, Sallie Putnam, frequently observed Varina coming and going during her various visits to the homes and boarding houses of some of her friends. Putnam praised the First Lady for both her comportment and admirable manners, and thought her perfectly suited for the role of First Lady of the Confederacy. Putnam remarked,

Mrs. Davis is a tall, commanding figure, with dark hair, eyes and complexion, and strongly marked expression, which lies chiefly in the mouth. With firmly set yet flexible lips, there is indicated much energy of purpose and will, but beautifully softened by the usually sad expression of her dark, earnest eyes. She may justly be considered a handsome woman, of noble mien and bearing but by no means coming under the description of the feminine adjective "pretty." Her manners are kind, graceful, easy and affable, and her receptions are characterized by the

\footnotetext{
95 Chesnut, 142.

96 Chesnut, 62, 109, 429.
} 
dignity and suavity which should very properly distinguish the drawing-room entertainments of the Chief Magistrate of a republic. ${ }^{97}$

That Varina placed herself before the public eye in dress and manner attractive to those who fell under her social rule proved incredibly important, as such displays during house visits won her the trust and the support of many of her followers to help govern Richmond society, both socially and politically, during the turmoil of war. Varina Davis was continuously selfaware that all ranks of society had something to say about her appearance and behaviors and that her reputation as a societal leader depended upon successful execution of a successful projection of respectability during both her visits to her friends' parlors and at informal gatherings that she herself hosted for other ladies. Varina's peers learned many social lessons from the First Lady and her mistakes. Armed with both their observations of Varina's social ordeal in Richmond and with their own previously acquired knowledge about the secrets to social acceptance and preeminence, the women of the capital elite carefully crafted both their appearance and their patterns of visiting to fit society's expectations for a lady of the upper class.

Evidence of Richmond ladies' preoccupation with their personal appearance and with establishing themselves amongst the "best" circles of upper-class women appears in both their own writings and in the commentary of contemporary social biographer, T.C. DeLeon. The ladies prudently selected certain homes to visit, such as that belonging to Jennie Pegram and Marie Paul (who later became the distinguished war-time bride of Captain William Myers), whose respectable reputation and well-connected friends would bolster their own status within the community merely by association. Their frequent, carefully crafted appearances at such distinguished houses thus became part of an elaborate social performance. If, during these gatherings, the ladies followed the appropriate social scripts assigned to them, they might win the

\footnotetext{
97 Putnam, 38.
} 
support of the hostesses and fellow elite guests. Such support and patronage helped the newcomers procure additional invitations to future, exclusive social events that could only help to push the new arrivals more squarely into the social spotlight.

Additionally, by continuously and successfully executing their assigned social roles at the gatherings, the ladies ensured their mention within ensuing, more intimate parlor chats held by the city's foremost hostesses who used such chats to discuss and sort out the latest "society stand-outs" from the social pretenders. A refugee herself, Constance Cary wrote fondly of the parlors and homes of native Richmonders, Jennie Pegram and Marie Paul Myers, and the mystical power that they seemed to wield over Richmond society:

Of the resident families, many of them abiding in the wide old ample houses, set back from the street in gardens of redundant bloom and foliage, with magnolia trees guarding the portals, that we would pass in our walks envying their suggestion of home delights, the list is longer. Not only do their names represent, to any student of Americana, the direct outgrowth of the best Colonial stock, but it would have been hard to find a group of gentle-folk better equipped to conduct the functions of good society. ${ }^{98}$

Luckily for beautiful and charming Constance Cary, these women readily accepted her into their homes and the innermost circles of Richmond society.

Cary went on to chronicle the reputations of all of Richmond's major societal leadersboth native and refugee--noting that almost all of them, with the exception of Mrs. Robert E. Lee, had carved out their prized ranking at the top of the social ladder through displays of gentility and respectability at gatherings hosted both within their own homes and at the homes of their distinguished peers. She also noted that each of these leading ladies had attracted certain "courts" of elite refugee women whose own reputations soon acquired that of their esteemed leader through mere association. Constance Cary explained that Mrs. Lee was exempt from such

\footnotetext{
98 Harrison, 157.
} 
essential social interactions, as she had other, much more serious roles to fill as the wife of the leading Confederate General:

The ladies of General Lee's family lived in a pleasant house in lower Franklin Street, then and afterward held as a shrine in the eyes of patriotic pilgrims. Mrs. Robert E. Lee, not strong in health and always a reserved woman in society, rarely showed herself in general gatherings. Miss Mary Custis Lee, who has for years been known to the exclusive circles of foreign capitals, having spent most of her latter life abroad, took the post of receiving and entertaining the friends and admirers who thronged around their doors.

Additionally, Cary noted that both familial mourning and an admirable sense of propriety as the wife of one of the Confederacy's most honored generals excused Mrs. Lee and her family from participation in many social affairs without at all endangering the Lee women's claims to respectability. Cary explained,

The death of a beloved daughter during the war, followed by that of Mrs. Fitzhugh Lee and her children, while her husband was in prison in the North, placed the family in mourning, disqualifying them for conspicuous appearance in society. Also, it was understood that Mrs. Lee felt a sense of impropriety in the suggestion that the wife and daughters of the commanding general of half-starved armies, himself sleeping always in a tent and living on ascetic fare, should take the lead in any entertainments of a social sort; so the old elegant hospitality of Arlington House, which had opened its doors to so many in the past, was allowed to pass away, to be renewed, however, at their future home in Lexington. ${ }^{99}$

The detail with which Constance Cary described the various ladies' manners, morals, and physical comportment— - both in public and behind the doors of the city's most distinguished homes - reveals the enormous symbolism, meaning, and purpose ascribed to such behaviors. As Cary's accounts suggest, the ladies behaved and comported themselves before others in carefully crafted ways that would both distinguish themselves from the hordes of threatening incoming strangers and social pretenders, and reaffirm their own social prowess and authority. Simultaneously, as ever-cognizant models of moral respectability, the ladies undoubtedly

\footnotetext{
${ }^{99}$ Harrison, 153-154.
} 
believed (however naively) that such fine displays of virtue during their traverses between houses might likewise instill in members of the "lowly masses" a greater regard for respectability and in turn inspire them to lead more respectable and orderly lives themselves. Thus, a lady crafted her appearance and manners not only to impress her peers from her own social class, but also to help inculcate a public admiration for the capital elite and renew onlookers' own dedication to upholding the cherished virtues of morality and respectability that the ladies perceived as essential to maintaining order in the capital city.

Cary's discussions of the various social "queens" of the Confederate capital, while at times exhausting to read, are critical to understanding exactly who comprised the inner circles of the capital elite. Furthermore, her descriptions highlight the exact details of those cultural scripts to which the ladies were expected to loyally adhere in order to achieve and maintain their social prowess. Even more importantly, Cary's accounts illuminate the larger physical and mental frameworks within which Richmond ladies operated and which infused their complex and everevolving perceptions of ladyship, social ranking, and respectability.

In her careful cataloguing of Richmond's social “queens," Cary wrote extensively about the "own little court of Mrs. Joseph E. Johnston, coming from the distinguished McLane family of Baltimore," and the two daughters of Judge Archibald Campbell, "late of the Supreme Court—Mrs. Lay and Miss Mary Ellen Campbell" who proved to be "an important element in the social side of Richmond life." In fact, while writing her personal memoirs in 1911, Cary noted that "[t]o no one memory of those days do I turn now, with kindlier feeling that to that of handsome and original Mary Ellen Campbell.."100 Cary then moves from family to family, describing the traits that made each lady worthy of status within the capital elite, but also giving

\footnotetext{
100 Harrison, 154.
} 
readers specific details as to which families the newcomers should make an effort to fall in with, in order to uplift their social position by association.

Cary wrote glowingly of South Carolina refugees, General John S. Preston and familythe "handsome aristocratic parents, two sons in the army and three daughters, like goddesses upon a heaven-kissing hill, tall and stately, with brilliant fresh complexions," as well as the refugee family of Samuel Cooper, whose daughter, Mrs. Dawson, "fair and thoroughbred, with a charming frankness of speech and manner, was one of my coadjutators in the founding of the Starvation Club, and with the joyous hours of my Confederate experience her image blends pleasantly." She praised Commodore Sydney Smith Lee and his wife, who had "nobly" given "all her stalwart sons to the Southern service" and Mary Chesnut, who with her " strength, sweetness, and vivacity of mind," was a "fixed star in the refugee circle of Richmond"---as were the "delightful Harrisons, of Brandon," a gorgeous plantation on the James River, who had come to Richmond to live in Franklin Street's distinguished Linden Row. ${ }^{101}$

According to Cary, Mrs. Myers, daughter of General Twiggs of New Orleans and young wife of General A.S. Myers, Quartermaster General of the Confederacy, supposedly "bewitched men and women alike," while Mrs. Clement Clay of Alabama was "ever foremost in providing things clever and original for the diversion of her friends." Cary went on to write of the beautiful belles of Richmond society who also frequented the homes of Richmond's ladies, including Miss Frances Daniel, Miss Lizzie Peyton Giles and even Evelyn Cabell Russell, a recent bride, who "disprove[ed] the statement that a Southern matron, however few of years, cannot hope to retain

\footnotetext{
101 Harrison, 154.
} 
the belleship of her former estate." 102

However, Constance Cary's own cousin, Hetty, always ranked number one in her heart as the most perfect belle in the entire city. Both men and women - elite and common - tended to agree. Constance and her peers admired the gorgeous Hetty who was "as fearless as she was beautiful," possessing a "rare beauty, perfect as if from a sculptor's chisel," with great poise, "round arms," intelligence and pure wit. Not only did Hetty Cary always dress the part of the city's leading belle; her manners and grace were impeccable. Constance observed she was “always straightforward, humble, generous and good mannered." Hetty's cousins idolized her unique beauty and perfect manners, constantly studying her style and trying desperately to emulate her. Together, they became known as the "Cary Invincibles," though the "court" of wealthy young belles who also gravitated toward Hetty also enjoyed her rare privilege. ${ }^{103}$

Cary also wrote admiringly of the Macfarland house on Grace Street, which "was running over with young and winsome women, including Miss Turner Macfarland....and her cousins the Bieme sisters." Cary was also a frequent visitor at the "hospitable dwelling of Mr. Barton Haxall" on Grace Street, whose home she was quickly welcomed into due to her long-standing friendship with Harriet Haxall (later the wife of Virginia Henry Wise, Jr., son of the Virginia governor), Lucy Haxall, and Mary Triplett (wife of Captain Philip Haxall) whom she met at a gathering at the house of Brigadier General and owner of the famed Tredegar Iron Works, Joseph Reid Anderson and his wife. ${ }^{104}$

Cary continued her survey of the capital elite, writing of the specific social circles that

\footnotetext{
102 Harrison, 155-6.

103 Harrison, 158.

104 Harrison, 158-159.
} 
distinguished themselves within the upper ranks of Richmond's social life. Cary noted that Miss Lizzie Cabell and Miss Mattie Ould, daughter of General Robert Ould were all part of a “younger set represented by Miss Triplett....Good-looking and well-connected [Miss Ould] stands out on the background of the day as a spontaneous wit and suave talker on any subject, one of those who, like Mlle. Julie de Lespinasse in the salons of old France, would have found her a special chronicler." She also wrote glowingly of the home of Dr. Charles Bell Gibson on Grace Street, which served as "a haunt of clever and responsive people, welcomed and inspired by Mrs. Gibson and her daughter Mary, to whose credit were circulated many 'bon mots' and amusing strictures on things current."105

But most of all, Cary lauded the home of Mrs. Robert Standard, a wealthy widow whom, Cary thought, "we all fancied...came nearer to realizing the French ideal of a salon than any other hostess in Richmond. She was a widow, reputed wealthy and of considerable personal distinction, handsome, dark-eyed and wondrously persuasive with the other sex, who came when she called and left promptly when she gave them a token change of mood."106 According to T.C. DeLeon, only the most select and amusing members of Richmond society received an invitation to her coveted salon. With her noted hospitality and lavish receptions, Mrs. Standard was revered by society for her many distinguished friends, worldwide travels, and her collection of the "most brilliant and brainiest" acquaintances at her entertainments. Although she boasted that she had never read a book, Mrs. Stanard's magnetic personality seduced all around her, men and women alike. By attending one of her renowned parties, Richmond's women instantly earned a spot within the hostess's highly respected court. Attendees eagerly sought out her invitations in an attempt to meet the dozens of "people noted for something already" who

\footnotetext{
105 Harrison, 159.

106 Harrison, 146.
} 
frequented her parties and whose affiliation could only increase a newcomer's own social standing among the capital elite. ${ }^{107}$

After the war, Mrs. Stanard only heightened her reputation through her many additional travels abroad, "always received with the cordiality befitting her recognized position as a leader in her own home... and to the last she maintained the gracefully imperious manner of the admitted sovereign — a 'she-who-must-be-obeyed' to all around her." Mrs. Stanard's wartime house gatherings attracted distinguished visitors such as Mr. Pierre Soule, of New Orleans, Secretary of the Treasury Judah Benjamin, who "brought there his charming stories, his dramatic recitations of scraps of verse and clever comments on men, women and books," Vice President Alexander Stephens, "rarely seen in other houses---spare, worn, pungent, [he] dropped in upon her sometimes." Cary's "brilliant friend, Mr. L.Q.C. Lamar lent the witchery of his presence [there]; all the foreigners in town made speed to attend her evenings; statesmen and soldiers, old and young, came into the circle of her magnetism." Cary concluded her glowing evaluation of Mrs. Standard and her legendary parties, "needless to add, the women of Richmond were not slow in availing themselves of her none too profuse invitations." ${ }^{, 108}$

Unsurprisingly, Constance Cary and her friends routinely flocked to the house of Mrs. Stanard, "where we were sure to meet the cream of society and all the distinguished visitors to the capital." However, visits to Mrs. Stanard's always required a fancy new dress in order to distinguish oneself from the droves of other young beauties vying for the attention of the most distinguished members of high society. According to Richmond's belles, Mrs. Stanard always seemed to have acquired a new dress through the blockade. Cary related one particular instance

\footnotetext{
107 DeLeon, 198-200.
}

108 Harrison, 159-60. 
in which she realized that she had run out of new dresses, and in a panic, tore off pieces of fawn and brown silk from two "venerable dresses in the family repertory" and creatively sewed on pieces of "inked quilling in curley cues" on her skirt and bodice along with some ruffles she had trimmed off another dress. Cary made such a stir with her new style that evening that, much to her horror, Mrs. Standard asked for her dress pattern. Panicked that Mrs. Stanard would find her dress out to be a fraud and fearing her own exposure as a "pretending" member of the capital elite, Cary lamented that "in the daylight, all the pressed places, pieced places, washing and iron quillings....would stand revealed!” Fortunately for Cary, she managed to re-work the underpinnings of the dress enough for it to pass public inspection and "the poor dear fraud did come back within the stipulated time!"109

Constance Cary's chronicling of the enviable forerunners in wartime Richmond society reveals that wealth, familial distinction, respectable character and manners, and personal connections with the elite of Richmond and other notable southern cities proved, in many cases, an easy ticket into the upper echelons of society; however, as noted in the case of Varina Davis, one's personal appearance and proper social skills also played significantly into one's acceptance as a member of the capital elite. Women of both the upper and lower classes commented on the importance of appearance and stylish dress in establishing one's social ranking. As Mary Chesnut noted in her memoirs, "Pride of birth must be deep seated — must be unalienable. Proud people true in everything else will beg, borrow, buy, or steal the semblance of it" in desperate envy to become part of that elite upper sect. ${ }^{110}$ In fact, numerous reports of lowly women and African-American women stealing silks, boots, parasols, watches, and other finery fill the

109 Harrison, 146.

110 Mary Chesnut, A Diary From Dixie, as Written by Mary Boykin Chesnut, Wife of James Chesnut, Jr.. United States Senator from South Carolina, 1859-1861, and Afterward an Aide to Jefferson Davis and a Brigadier General in the Confederate Army (New York: D. Appleton and Company, 1905), 141. 
Mayor's Court columns of Richmond's newspapers, illustrating how zealous the "lower sort" were to acquire some semblance of respectability through the acquisition of "ladies' apparel."111 In September of 1863, The Southern Punch quoted one lowly servant girl, writing to her parents back home, who observed that "as for the low necs [dresses], the lower you wars em the more fashnabil you ar...we attrax a great deal of attenshun....prominadin in the streets lyke other ladys and holdin up our clos. Nobody isn't nothing now wich dozn't hold up her clos."112 For that reason, Richmond's ladies—-both native and refugee—obsessed over their personal appearance when in public and during house visits.

Even those women who had resigned themselves to a solemn life of charity work and sacrifice during the war, such as wealthy refugee Kate Logan found it impossible to maintain a proper social life without the essential garments of elite ladyship. Logan defended her own relapse into a lifestyle defined by material distinction, writing,

When I went South, I gave up frivolities....my mind always had two sides-a serious and a merry one; but I had never loved fashionable society, so- called...I thought I had burned my bridges when I refused to take any ball gowns with me and "gave out" to Mrs. Towns on arrival that I would not accept invitations to any large affairs...but when the occasions came, the dresses came also. Downtown we were driven and the white silk, brocaded with oak leaves and acorns, stiff and too smart for a young girl, was purchased and made....I had a lovely little jacket of lace to slip on over my bare neck and arms... ${ }^{113}$

However, Mary Chesnut observed, one could not simply adorn herself in the latest fashions and waltz into the house of any "leading lady" of Richmond. In fact, Chesnut critiqued the flood of incoming refugees who, unlike herself, had not taken time before the war to cultivate friendships with the "right" people, but took it for granted that they would receive admittance

\footnotetext{
111 Richmond Examiner, August 5, 1862; Richmond Whig, April 14, 1864; Richmond Whig, April 20, 1864.

112 Southern Punch, September 26, 1863.

113 Logan, 9.
} 
into the most esteemed houses in the Confederate capital. "These people want to gather a crop of fame when they have hardly begun to sow the seed," Chesnut observed. "Hold on and wait," she cautioned these zealous newcomers, and let "patience possess your souls."

Though they all established themselves as worthy members of the capital elite early on in the war, Constance Cary, Mary Chesnut, and Virginia Clay filled their memoirs with pages upon pages of critical reflections on the dresses, shoes, hats, and jewelry that they made sure to sport when out visiting in order to maintain their prominent social standing. As fellow leading lady, Sarah Lawton, wife of the Confederate Quartermaster mused, “' 'What would man be,' says Carlyle, 'without his blankets,' and what would I be without mine?" 115 These women also dedicated a significant portion of their diaries to analyzing, in extensive detail, the dress of their peers as well. During the inward-turning years of late 1863 to 1865 , ladies favored home visits and informal private gatherings even more, justifying them as essential to the maintenance of elite morale, political functioning, and social ordering. During this time, when shortages due to inflation and the blockade made the acquisition of "proper" social attire even more difficult, Cary wrote that "the ladies plaited straw hats around the evening lamp," sewed "dreadful looking gloves of chamois leather," and often acquired battlefield loot, such as needlebooks, soap, combs, brushes, and scissors from their soldier sweethearts to help enrich their toilette. ${ }^{116}$

Sara Pryor, the distinguished wife of the fire-eating newspaper editor and politician, Roger Pryor, was able to make an independent living off of cutting up her old, faded silk gowns

\footnotetext{
114 Chesnut, 145-6.

115 Sarah Lawton to her sister Louisa, May 16, 1864, and Sarah Lawton to her sister Clifford, September 7, 1864, in Marion Alexander Boggs, ed., The Alexander Letters, 1787-1900 (Savannah: Printed privately for George J. Baldwin, 1910), 267, 272.

116 Cary, 135; Diary of Anita Dwyer Withers, May 4, 1860-June 18, 1865, San Antonio, Texas and Richmond, Virginia, The University of North Carolina at Chapel Hill, "Documenting the American South" http://docsouth.unc.edu/imls/withers/withers.html, 61, 63, 68, 104.
} 
and bonnets and refashioning them into gloves, feathery hat accessories, lace collars, and dress appliques that she sold to wealthy women who were desperate for some fresh "flash" to add to their own wardrobes. Herself an admirer of fine fashion, Sara Pryor "knew that all women had a natural desire for beautiful raiment," as well as a social need for such attired, and was convinced that "the consciousness of being well dressed brought more peace of mind than even religion" to these wealthy ladies. Although her maidservant sharply critiqued her for "tempting them po' young lambs in Richmond to worship the golden calf and bow down to mammon" and for "sholy leadin' em into vanity," Pryor's awareness of the social value of clothing enabled her to live comfortably off of her personal clothing enterprise. ${ }^{117}$

For some women, however, elegant, homemade attire simply was not good enough. Desperate for the fineries of life that would help distinguish them in a community of strangers and riff-raff, Constance Cary, Kate Mason Rowland, and Anita Dwyer Withers didn't hesitate to place their orders with traveling officers and politicians for sewing cotton, fine flannel, and corsets from Maryland, or boots brought through the blockade down in Nassau by a French General. ${ }^{118}$ Rowland recounts ecstatically tearing into a "long-awaited box from Nassau" that arrived for her and her female friends through the blockade, in June of 1863: "We sat on the floor in the girls' room, diving in, discovering something that was just what we wanted at every grasp. What a treasure it is; many thanks to the absent sailor!" 119 Upon completion of a trip up to Washington in February of 1862 with her aunt to deliver papers of inheritance from her recently passed brother, Cary returned not with foodstuffs or medical supplies for the city hospitals, but

\footnotetext{
117 John C. Waugh, Surviving the Confederacy: Rebellion, Reunion, and Recovery-Roger and Sara Pryor During the Civil War (New York: Harcourt, Inc., 2002), 246-9.

118 Harrison, 135; Withers, 103; Kate Rowland diary, entry for June 14, 1863, Kate Rowland Papers, Civilian and Home Front Collection, Eleanor S. Brockenbrough Library, Museum of the Confederacy (Richmond, VA), 121; see also, Sarah Lawton to her sister Clifford, September 7, 1864, in Boggs, ed., 272-3.

119 Kate Rowland diary, entry for June 14, 1863, Kate Rowland Papers, Civilian and Home Front Collection, Eleanor S. Brockenbrough Library, Museum of the Confederacy (Richmond, VA), 121.
} 
with a new hat and gown, gloves, and new boots! A so-called "arbiter of fashion" in the Confederate capital, Cary clearly had her priorities set on buffering her own place within the social ranks of Richmond. ${ }^{120}$

Additionally, no distance seemed too great to stop Cary from even ordering from New Orleans a veil made of "real" black thread lace whose bearer, a male family friend, had to make the journey personally from New Orleans to Richmond to deliver the prized piece. ${ }^{121}$ Cary even noted one instance in which a private in the Confederate army brought back a pair of stays from Maryland for his fiancée, while a southern blockade runner returning to port unloaded (to great profit) "instead of arms and drugs, an entire cargo of corsets...for 'women must lace, while men will fight' might have been a motto of the hour!"122

Refugee Judith McGuire was in awe of the number of personal friends who risked passing through the lines in Washington numerous times during the war in order to bring back non-essential luxury items such as pocket handkerchiefs, stockings, traveling dresses, and petticoats. ${ }^{123}$ Well-to-do Kate Rowland, who attended some of the most lavish gatherings in the city during the war, even remarked, in February of 1863, on how surprisingly "elegant" certain parties were "for war times...the toilettes, some of them magnificent [with] velvet and diamonds and silks and point lace." ${ }^{, 24}$ Meanwhile, in the autumn of 1864, Virginia Clay proudly placed her order for a new set of finery as she bounced back and forth between visiting friends at Redcliffe, the lavish South Carolina home of the fire-eating politician, James Henry Hammond, and Richmond.

\footnotetext{
120 Harrison, 98, 116.

121 Harrison, 135.

122 Harrison, 136.

123 McGuire, 184.

124 Kate Rowland diary, entry for February 11, 1863, Kate Rowland Papers, Civilian and Home Front Collection, Eleanor S. Brockenbrough Library, Museum of the Confederacy (Richmond, VA), 109.
} 
Eventually, however, Mrs. Clay noted that even she and her lady friends were forced to drag out the dreaded spinning wheel and handlooms, as well as scraps of old leather in order to repair their faded finery and craft new dresses and shoes of old, rough materials in order to maintain their distinguished appearance. Despite the sobering effects of war, for Cary and her friends, it was "not that our love for pretty things [was] dead." Clay proudly boasted that "calico in the commonest was expensive" and that "we women of the Confederacy who cultivated outward indifference to Paris fashions...would have astonished our former competitors in the Federal capital" as "our appearance didn't suffer." Clay and her peers spent hours laboring over new muslin gowns from the Macon mills, trimming them up with gourd seed buttons and dying them crimson in order to make themselves fashionable. ${ }^{125}$

However, Clay ultimately found these dresses to be too "common" for her social position, and she could not resist the temptation to write to her husband, Senator Clement C. Clay in November of 1864, begging for twenty-five items of finery that she thought he would be able to acquire on his present trip through Canada. Virginia unabashedly wrote to Clement, "Bring me at least two silk dresses of black and purple; I prefer the purple to be moiré antique, if it is fashionable. If French importations are to be had, bring me a spring bonnet and a walking hat, and for the benefit of all my lady friends and myself, do bring some books of fashion — the September, October, and November numbers." Clay's list went on, including such items as:

Corsets, slippers with bells, gloves, extra fine hankies, black silk dresses for Lestina [a domestic slave], flannel--red and white, a set of fine dark furs-- no more than 25, a set of Hudson Bay Sables, any price.... large cape, cuffs and muff, two black Hernanis or Tissue dresses, one tissue dress to be brochetted, three to four pieces of black velvet ribbon--different widths, bolt of white bonnet ribbon, pink, green and magenta French flowers for bonnet, shell tuck comb; ....a Present for little Jeff D[avis], Vlaude and J. Winter, needles, pins, hairpins,

125 Clay-Clopton, 223, 225-6. 
toothbrushes, coarse combs, cosmetics, hair oil, cologne, domestic, linen, swiss, jaconet, mull muslin in full piece----dresses of brilliantine, black silk spring wrapping, chlorine tooth wash and Rowland's Kalydor, cut coral necklace, lace collars, large and pointed--not worn... ${ }^{126}$

Mrs. Clay’s wish list was unquestionably extravagant for a time of war. However, as such an active member of high society, both in Richmond and throughout the South, Virginia Clay believed that it was absolutely essential for her to dress the part in order to retain her high social status and authority as a societal leader. Mary Chesnut, too fretted about her ability to live up to the stylish expectations of the fellow women of her class. Constance Cary wrote of one particular day when she went to visit Chesnut. A worshipper of Chesnut's "gay and sprightly" nature, Cary empathized with Chesnut's plight when she found Mary at home, anxious and sulking, and "lamenting that she hadn't a bonnet of any kind to wear in full dress." Disgusted by the outrageous five-hundred-dollar price tag on most of the hats in town, many of which were "made of the homeliest materials from 'other side' patterns," Chesnut pleaded with Cary for help in learning the art of millinery. "Wouldn't I advise her and earn her undying gratitude?" Cary noted. Constance Cary rushed to Mary Chesnut's aid, instructing the Preston girls, who were also visiting at the time, to also join in as she helped to rip up old velvet bodices, "mignonette green in hue, a point lace barbe, and some sprays of artificial nasturtiums, pale yellow and old gold, and set to work to shape over an old bonnet frame." I worked on," Cary proudly wrote, "till a very stylish and becoming head-piece was evolved." Chesnut was so relieved and thrilled by Cary's fashionable creation that she "declared she wore it with pride to every function of state or fashion afterward."127

While ascribing to the social prescriptions for appropriate dress and behavior during

\footnotetext{
126 Clay-Clopton, 223, 225-6.
}

127 Harrison, 148. 
visits to others' houses was critical for establishing and maintaining one's claims to ladyship, Mary Chesnut's memoirs also reveal that a lady's ability to host respectable home gatherings also contributed significantly to her reputation as a worthy member of the capital elite. Although she initially enjoyed the intimate friendships of the capital elite at the Spotswood Hotel in 1861, Chesnut was forced out of her privileged abode in 1862 when overcrowding in the city and the expansion of military hospitals into private homes and buildings forced her into temporary residence at various boarding houses. After a brief stint at the Ballard Hotel, located just one block from Capitol Square, Chesnut wrote that she was "forced by trouble and loss of property" to "live with some decayed ladies — a dreadful refuge of the distressed it was," and though her new home was comfortable and provided decent meals, she was "forced to assume the patient humility of a poor relation." 128 Chesnut cringed at her inability to run her own independent household — however small—and thus feared for her ability to maintain her social prowess.

Luckily for Chesnut, as the war dragged on, tightly-packed boarding houses and scantilyfurnished homes had become the standard for the hosting of parlor visits. By the winter of 18621863, Chesnut was living in the house of Mrs. James Lyons where her "private room" consisted merely of a hastily enclosed section of a larger drawing room. Chesnut deeply lamented her lack of privacy and the dingy and inadequate parlor that served as the only entertaining space in the house. However, by that point in the war, elite refugees had realized that the necessities of war compelled them be creative in snatching back dignity and respectability from the jaws of degradation. Thus, much to her relief, her peers continued to rally around her (now noticeably smaller) parlor, where there she "danced to the music of an old ramshackle piano and had a good time generally." Chesnut proudly declared this new form of entertainment a success, writing

128 Chesnut, 429 
that, "We received all that the Confederacy had of good and great from Mr. President Davis, the Lees, Mr. Hunter, down to the humblest private who was often our nearest friend or relative....Every night our parlor was crammed to capacity."

What is particularly interesting about this specific passage from Chesnut's diary is her illumination of the ways in which both the duration and the increasing intensity of the war reshaped early-war notions of social acceptability. Chapter two will delve more deeply into a discussion about this transformation. However, it is interesting to note that, while the material conditions in which the elite gathered during house visits naturally deteriorated, due to the war's widespread shortages that affected members of all classes, the ladies appear to have redoubled their efforts in trying to perpetuate elite social rituals by adapting and transforming even more intimate, make-shift parlors and dining rooms into exclusive social fora.

This preoccupation with creating an elegant and respectable social forum out of increasingly rare and deteriorating materiel reflects the mounting importance that the ladies ascribed to their elite social gatherings over time in both maintaining the mental and emotional health of the capital elite and defending their own claims to ladyship. The shrinking availability and size of such gathering places over the course of the war resulted in yet more exclusive social functions to which an invitation assumed even greater symbolic significance of both the hostess's and the attendees' social ranking. In turn, the ladies placed even greater value on the safety, familiarity, and comfort of these more insular gatherings.

Throughout the war, Richmond's ladies continued to rely on house visits as a forum in which they might reaffirm their elite status both before their peers and, through their travels to

\footnotetext{
129 Chesnut, $420 ; 430 ; 432-3$.
} 
and from said visits, before the public. However, the ladies complemented these ritualized visits with another, increasingly popular social ritual whose detailed scripting rivaled that of the house visit: Exclusive party-going. 


\section{Chapter 2-- The Unbearable Heaviness of Being: \\ Elite Parties, the Defense of Ladyship, and the Maintenance of Morale in the Confederate Capital}

During the winter of 1862-1863, much to her own surprise and relief, the Confederacy's controversial First Lady won the admiration of high society by hosting a wildly popular matinee musical. ${ }^{130}$ The musical was so successful that, after one instance in which Varina Davis hosted a breakfast and "talent show" for some foreign dignitaries visiting her husband, both the Richmond elite and the city's under-classes clamored to know every detail about each performance. The high profile of the breakfast and talent exhibition, and the constant barrage of questions that circled around society about the event afterwards, reveal the zeal with which Richmond women viewed such entertainments as an illumination of the social talents, prowess, and (in turn), social authority of both the hostess and her select guests.

Always aware of fellow Richmonders' thirst for scandal and gossip, Richmond ladies carefully crafted each and every aspect of their own parties, as well as their attendance at friends' social functions, with a conscious eye toward how best to reaffirm their own status and respectability within the ranks of the capital elite, and how to successfully reconfirm for the public their legitimacy as arbiters of social morals and order in the Confederate capital. During a conversation between Mary Chesnut and Varina Davis, Chesnut sharply warned the First Lady about making light of such events. An exasperated Varina, weary of the public's constant questioning and obsession over her breakfast, drily joked to Mary Chesnut that, in truth, "we danced on the tightrope!" Acutely aware of these entertainments as high-stakes social statements, Chesnut quickly cautioned Varina, crying "have mercy, my dear, never say that 
again. They will believe you. You do not know this Richmond. They swallow scandal with such wide open mouths and their easy credulity is such — next winter they will have the exact length of our petticoats and describe the kind of spangles we were sprinkled with!"131

Similar to their reliance on house calls as a means to demonstrate proper social decorum befitting an elite woman, Richmond's ladies used their exclusive parties as an additional means of negotiation and reaffirmation of their social legitimacy amongst the swirling tide of incoming ladies striving for a niche within the upper echelons of society. However, the ladies also used the parties as a way to uphold the unity, strength, and morale of the upper classes during the particularly despondent times of war, as it was only through such unity of persons and purpose that they could serve as both models and arbiters of social order within society at large. As the guardians of cherished social traditions that were constantly being threatened by the war, the ladies appear to have viewed it as both their duty and their privilege to uphold such necessary traditions.

Additionally, as was true of their house visits, the ladies' conspicuous comings and goings for the parties themselves served as a display before their social inferiors not only of elite privilege and an affirmation of their social power as arbiters of moral order in the city. In the minds of the leading ladies, the women's elaborately crafted displays of elegance and virtue might, in turn, inspire the rougher, cruder members of society to replace their poor behavior and tendencies toward vice with strides toward self-betterment, or that such inspiring public showcases might help to correct the ways of potentially tempted or straying members of the

\footnotetext{
131 Chesnut, 434.
} 
middling classes. ${ }^{132}$ Through their ostentatious exhibitions of elite identity on their way to and from the parties, the leading ladies believed, they thus might be able to begin the process of restoring order and morality back to both their civilly and civically besieged society.

In addition to hosting private parties, Richmond's ladies relied heavily upon their ritualistic hosting of New Year's Day receptions as a means to showcase and reaffirm their social prowess, hostessing skills, and ability to contribute to the morale, cohesion, and privilege of the upper classes. Like most other private, formal gatherings, ladies’ New Years receptions increased in number and in scale over the course of the war, reflecting the elites' preference for private gatherings with their peers. ${ }^{133}$ Although these receptions were intended largely for the gentlemen of the city, whose New Year's Day ritual consisted of a series of house visits with elite male friends, the men's observations and judgments of each hostess's abilities to create a successful reception for the male head of the household and his friends unquestionably were relayed to his own ladies and then circulated throughout his social sphere. ${ }^{134}$ With the city's ladies constantly seeking the latest gossip and news about each other's parties, gatherings, and other social engagements, it is certain that information and commentary about the leading hostesses' receptions swirled through the streets of Court End and the Capitol Square neighborhood.

Additionally, the non-hostessing ladies often held small tea parties and gatherings for their female friends on New Year's Day that created an additional forum through which they might advance, or even reaffirm, their own social position and talents either by showcasing their

132 Amy Karen Rider Minton, "A Culture of Respectability: Southerners and Social Relations in Richmond, Virginia, 18201865," (Ph.D diss., University of Virginia, 2006), ii, 2, 18, 309.

133 Richmond Daily Dispatch, January 2, 1862.

134 Putnam, 90. 
social abilities or by surrounding themselves with the female kingpins of society with whose association they might improve their own reputation. ${ }^{135}$ At these holiday tea parties, the leading ladies served eggnog and discussed the latest social gossip. While New Year's Day receptions and tea parties could never supplant the importance of daily house visits and regular party-going, they did provide yet another, annual stage on which both hostesses and attendees might audition for a place among the capital elite by showcasing their rights to elite ladyship before a discerning society of social critics.

Constance Cary's preparations for her first Richmond party following her arrival to the city during the winter of 1862 reveal the importance of such parties in determining one's ranking in the social order and illustrates the pressures which ladies such as even the pretty and charming newcomer Cary felt while on display before all of Richmond society. Cary considered this gathering, a costume-themed party held at the home of a Mrs. McMurdo on Grace Street, "one of the fanciest affairs of the winter." In turn, Cary asked her mother to make her a costume of a Louis XV court lady, for which Cary dug through her family trunk for old petticoats and wine colored silks. She busily spent the days before the party shopping for spangles to adorn her shoes, a fan, feathers for her "high rolled, powdered hair," a mask, a pearl necklace, and blonde lace. She even went through the effort to secure a fancy coach and horses to drop her off at the party in high style. ${ }^{136}$

Constance Cary used the McMurdo party as an opportunity to make a multitude of social statements, both to her elite (hopeful) peers, and to those whom her coach would pass on the streets en route to the party. Through such a flashy performance, Cary foisted her way to the top 
of Richmond's social ladder while simultaneously helping to further distance and partition the true ladies of the capital city from the lowly riff-raff and over-zealous pretenders who threatened the purity of Richmond's social hierarchy.

At the McMurdo party and at the parties that Cary and her mother hosted in 1862, Cary and her peers made sure to offer up an impressive sampling of eggs, butter, potatoes, salted meats, and rice, served atop elegant china, glass, porcelain plates and cups to further enhance the hostess's prowess as a social leader. ${ }^{137}$ Mary Chesnut even made sure always to keep a fresh supply of turkeys, wine, potatoes, hams, and pickles on the table throughout 1862, despite the astonishing rates of inflation that priced turkeys at thirty dollars apiece. ${ }^{138}$ As selfish and as incomprehensible as it may now seem for these ladies to have been enjoying such delicacies while soldiers and the poor began to experience the first pangs of starvation that year, the ladies were acting out of an ingrained cultural mindset that necessitated such extravagance for one's "social survival."

Additionally, these women also were engaging in what they believed to be an essential, core set of social rituals that bonded them together around a sensibility of respectability and privilege. The women considered this collective sensibility critical to maintaining not only the strength and power of the capital elite to govern over society, but also the moral refinement necessary for buoying the elite above the vice and degraded state of being that the war seemed intent on imposing upon society. Although the elite had always prided themselves upon their moral rectitude and prowess that had seemed almost inherent to members of the highest classes, the ladies could not afford to take such previous distinction for granted. For the capital elite,

\footnotetext{
137 Harrison, 117.
}

138 Chesnut, 434. 
now - during the war more than ever — the maintenance both of individual social standing and collective class standing required constant attention to one's social projections during parties, including dress, dining, conversation, and amusements. In the minds of the elite, the vice-in all its many forms - that had seemingly seized control over much of common society posed an everpresent threat to high society as well. Such a threat demanded heightened efforts toward preserving respectability and refinement among the upper classes as a whole in order to ensure that the war did not completely destroy the pillars upon which the rest of societal order rested.

Both Anita Dwyer Withers and Constance Cary noted that, once a lady had carved her way into a position on the top rungs of the social ladder, such status was never considered permanent. In fact, one often could only manage to remain there during the challenges of war through the aid of one's peers and a collective, upper class dedication to preserving such privilege in the face of continuous threats to respectability and the existing social order. Constance Cary noted that she never would have been able to indulge her guests in the aforementioned delicacies had it not been for her peers' constant, collaborative efforts toward continuing such traditions. She stated that, just as ladies were expected to assist struggling upper-class peers with invites to informal house gatherings, boarding house hostesses often contributed to the success and reputation of Cary's own social gatherings by donating china and glassware to several of Cary's group parties. Meanwhile, other families willingly shared fine pieces of furniture, such as dining room tables, with peers who were in need of such items for entertaining. ${ }^{139}$

Anita Withers wrote of elite women constantly lending their expertise to friends in need

\footnotetext{
139 Harrison, 117.
} 
of help in other areas of their life, such as dress-making and decorating. ${ }^{140}$ Kate Logan even recorded giving numerous ball gowns to fellow elite friends in the later part of the war when the blockade and severe inflation made certain pieces of finery scare for even the city's wealthiest women: "By 1863 we were suffering for materials for gowns and other necessary clothing," Logan stated. She continued, "I had had abundant outfits when I went to Macon but my dresses were all laid aside, as I was in mourning during the whole war from the time of my brother's death." Finding a positive component to her otherwise tragic situation, Logan cheerily wrote that, "in this way I was enabled to help others, and I think I kept but three of my gowns---a black velvet, a blue and grey silk, brocaded, besides two white silk gowns, and a white grenadine with pink flowers. It was impossible to keep things lying around when one's friends were in dire need. ${ }^{141}$ In assisting each other with preparations for parties, party-going, and party-hostessing, these women enabled each other to maintain their cherished position as social queens in the Confederate capital while also re-solidifying the bonds of ladyship that were necessary to support the solidarity and morale of the city's ruling class as a whole.

As one of the most active social queens and avid social chroniclers of the Confederate capital, Mary Chesnut recorded numerous details of her party rituals and provided astute analyses of the talents of each of the male and female attendees. Attending balls, tableaux, dinners, private theatricals, charades, teas, receptions, and other gayeties on a routine basis, Chesnut wrote profusely about the exclusive parties held in Richmond during the war. Making her way from one evening gathering to the next, there were nights when she did not arrive home until 3 am, even occasionally on the Sabbath! ${ }^{142}$ The usual set of hostesses and attendees appear

\footnotetext{
140 Withers, 68.

141 Logan, 42.

142 Chesnut, 554, 560.
} 
throughout Chesnut's writing, including Mrs. Randolph, Mrs. Semmes, Mrs. Anderson, Mrs. Stanard, Mrs. Ives, and Varina Davis.

For her part, Varina Davis hosted numerous (and popular) teas and luncheons exclusively for Richmond's leading ladies. Serving gumbo, duck, olives, chickens in jelly, oysters, lettuce salad, chocolate jelly cake, claret soup, champagne and other delicacies, the First Lady tried to properly fulfill her responsibilities as the ever-scrutinized figurehead of Confederate hospitality and social leadership. Varina Davis was well aware of the fact that she was expected to serve as a model of ladyship for Richmond, and for the Confederacy as a whole - the model to which southern women would look for notions of how to lead a moral, proper, dutiful life.

For many women, Varina's hostessing rituals as a social kingpin of the Confederacy set the tone for how other leading ladies should comport themselves within society in order to maintain their own social prowess as leaders and guardians of respectability. The ladies' emerging reputations as legitimate arbiters of moral order within the Confederate capital made them instant objects of emulation among the elite refugees of the late war period. Additionally, their models of ladyship helped to establish clear differentiations between true "ladies" of the upper classes and mere "mock ladies" of the lower classes that were useful for all members of society. In November of 1863, the popular periodical, Southern Punch, affirmed the claim that "to expose vice...does more public service" for society than does any official act of politics. ${ }^{143}$

However, as the war progressed, the female capital elite could not afford merely to rest on their social laurels from the early war years. As a fellow social kingpin of Richmond society, Constance Cary grew increasingly concerned when, during the Fall, 1863, the city experienced

143 Southern Punch, November 7, 1863; March 12, 1864; 
yet another uptick in the number of new arrivals to the city. Many of these newcomers included the "many gray clad figures," who required constant entertaining which placed even greater pressure upon the leading ladies to perfect their social performances of elite ladyship before the incoming tide of strangers. Cary herself fretted about the "daily increasing need of wearing apparel...to meet the demands of the entertainments." Fearing that her own apparel lacked the elegance, flash, and style that her role as a leading lady demanded of her, Cary once again begged her mother to alter her best evening dress to attend the "smartest party of the season" hosted by Mr. and Mrs. Allen, in Edgar Allen Poe's childhood home. Boasting a supper of creamed oysters and chicken salad, washed down with supposedly ten thousand dollars worth of champagne, Mrs. Allen's party was one of the most publicized, yet exclusive, gatherings of the entire autumn. ${ }^{144}$ This celebrated party provided a clear delineation of the Richmond social hierarchy by reinforcing both Mrs. Allen's own social prestige and that of her select guests, while also celebrating the virtues of respectability, refinement, and hospitality—virtues to which the hostess and her peers hoped, for the good of Richmond as a whole, all members of society would eventually aspire.

Cary's writings go on to chronicle the many cotillions that her peers hosted during that fall and winter of 1863 , revealing the extent to which Cary and her peers were ever conscious of the social stakes involved in such projections of respectability and ladyship. "They were the jolliest imaginable, and there were constant demands to admit new members," Cary gushed. "All the foreigners and general officers who visited Richmond presented to our club as a means of viewing the best society of the South." ${ }^{145}$ Cary could not say enough good things about these lavish gatherings, writing, "[h]ow wonderful were the toilettes concocted that festal

\footnotetext{
144 Harrison, 146-8.

145 Harrison, 150.
} 
winter...maternal party dresses that had done duty at Newport, Saratoga, Sharon, White Sulphur Springs, and in Washington and New Orleans ballrooms were already worn to rags." Cary wrote glowingly about the "romantic" industriousness that she and her peers proudly practiced before such affairs, noting, "the oft told stories of damask curtains taken down to fabricate into court trains over petticoats of window curtain lace and of mosquito nettings made up over pink or blue cambric slips now took shape." She proudly declared that their work had paid off, and "certain it is that girls never looked prettier or danced with more perfect grace than those shut-in war maidens. ${ }^{146}$

A male friend of Cary's likewise swooned over these celebrations of class privilege and respectable living, writing in a letter to Cary,

Lord! What a sizzling, wholesome, highbred little society it was. Night after night, I galloped into town to attend dances, charades, and what not ... And did not get back to my camp until 2 or 3--what matter the hour? But was always up fresh as paint when reveille blew...to you and to me, ...it was such a blending of a real Heroic Age and a real Golden Age, that could come but once in a million years. Everybody knew everybody (in the highest sense of the phrase) and there was youth, and beauty and devotion and... daring, a jealous honor and an antique patriotism, an utter self-abnegation and utter defiance of fate, a knightly chastity and beautiful surrender of the coyest maid...God! What a spending high society that little handful was... ${ }^{147}$

Other diaries and letters of numerous elite Richmond women, as well as local newspaper accounts of the parties, highlight the leading ladies' preoccupation with every, ritualized detail of these celebrated parties. None of these details was too small to overlook, as the ladies believed that such parties were essential to establishing and maintaining the ladies' social prowess, inculcating moral order and respectable living in the city, and bonding the capital elite together

\footnotetext{
146 Harrison, 151-2.

147 Harrison, 151.
} 
throughout the war period. ${ }^{148}$ Mary Chesnut and Constance Cary recounted the numerous and elaborate dinner parties, luncheons, and teas that they hosted for President and Mrs. Davis, Georgia Senator Howell Cobb, Custis Lee, Mrs. Ould, the Preston sisters, Mrs. Randolph, and Mrs. Lyons, as well as a casino party which hosted in honor of General John Bell Hood. ${ }^{149}$ Likewise, T.C. DeLeon raved about the "beautiful pictures" [tableaux] presented by Hetty Cary and young Mattie Paul, as well as the numerous little plays, recitations, music, poetry, and prose that filled the homes of the city elite, such as Mrs. Semmes, Mrs. Ives, Mrs. Webb, and Mrs Grant. $^{150}$

In one particularly detailed account of the rituals in which the ladies engaged to prepare for these social functions, Mary Chesnut described her careful crafting of the dinner table and the endless supply of eggnog, apple toddy, fresh butter, coffee, and eggs that she proudly served at the fancy occasions, as well as the ensuing merriment that she and her guests felt at laughing, chatting, and dancing the evening away at such gatherings. ${ }^{151}$ For these gatherings, the women often rented elegant carriages to transport them through the city at astonishing costs. Often, the ladies rented the carriage for several hours and sent it back and forth to their friends' houses to transport them to the parties and thus maximize the value of the high rental fees. Mary Chesnut's January, 1864 rental of a carriage for the transport of herself and her choice friends to a party at Mrs. Stanard's house for the whopping price of twenty-five dollars an hour illustrates the lengths to which the leading ladies would go to craft a respectable appearance of themselves before the public. ${ }^{152}$ With both the physical evidence of such parties flooding the streets of downtown

\footnotetext{
148 For newspapers, see particularly, Southern Punch, August 15, 1863, September 26, 1863, October 10, 1863, October 24, 1863, November 8, 1864;

149 Chesnut, 502-505; Harrison, 134.

150 DeLeon, 219, 223, 229-244.

151 Chesnut, 507-8

152 Harrison, 128; Chesnut, 528.
} 
Richmond and the journalistic coverage of several of these grand events, it is impossible that the "lesser public" was not aware of the upper class's gayeties. Indeed, such public broadcasting of these events was exactly the desire of Richmond's ruling class.

It is interesting to note, however, that, as the war dragged on, Richmond's hostesses began to feel the need to increasingly justify their lavish entertainments both to the public and themselves. Such was especially true starting in the summer and fall of 1863 and continuing on through the rest of the war. The perceived need for such justification likely grew partially out of their own consciences, as the women could not help but contrast their elaborate parties and gayeties with the sufferings of their soldiers on the battlefields. Additionally, increasing scorn from the ladies' critics undoubtedly influenced their discussions about such events. The majority of that critique did not emerge until mid-to-late 1863, which coincided with the ladies' more vocal justifications of their social gatherings. However, it also appears that the war itself was transforming women's perceptions of these elaborate social performances into semi-political performances. Part of this transformation may have been due to the rise of Confederate nationalism, and the perceived need to promote that nationalism for the sake of the war effort, over the first two years of the war. ${ }^{153}$ As the war began to broaden the ladies' awareness of the need for political order in the Richmond community, it ultimately began to merge the elites' understanding of their own social privilege and responsibilities with their sense of political responsibility as well.

By 1863, women such as Constance Cary and Mary Chesnut commented that, with so many soldiers and officers camped on the outskirts of the city and passing through the city on

\footnotetext{
153 See, for example, Drew Gilpin Faust, The Creation of Confederate Nationalism: Ideology and Identity in the Civil War South (Baton Rouge: Louisiana State University Press, 1988).
} 
serious official business, it was "our duty to make our soldiers forget the discomforts of camp" and that a primary reason for the ladies' obsession with their appearance at such events was that they were "trying to convey the great fen's behest and look their prettiest for the gallant survivors" of the army. ${ }^{154}$ By 1863 , the Confederacy experienced some of its most depressing and demoralizing blows, both on the battlefield and at home, where inflation, shortage, speculation, and crime skyrocketed. Confronted by this double threat to their fledgling nation and to their way of life, Richmond's ladies became attuned to the fact that the Confederacy needed their support of its southern soldiers and the war effort more than ever. Without that increased support, the ladies feared, it was possible that the Confederacy might fail, and that the precious social order and their own highly cherished status as elite ladies—a status for which they had striven to defend for so long — would ultimately disintegrate. Thus, the ladies began to view their parties not only as social, but also as political necessities wherein they might raise the morale of the Confederacy's soldiers and political leaders, and ultimately help to support the Confederate cause. By renewing their support for the war effort through "patriotic parties," the ladies believed that they not only were contributing to the defense of their new nation, but that they also were helping to preserve a cherished way of life that perpetuated their own class privilege and held together the vital social order upon which Confederate society was predicated. Although it might be easy to label the ladies' new-found justifications for their revelries as a mere excuse or "cover" for what some historians have labeled their selfish proclivities, it is worth investigating the possibility that the ladies truly believed that the continuation of such parties was a moral good, and in fact, a necessity which would benefit all Richmonders. The ladies, such as Constance Cary, used such justification repeatedly, when, in 1863, Cary instituted what she called the Starvation Club, a group that sponsored regular "starvation parties" (to be 
discussed in more depth in chapter six), which proved quite popular among the elite. At the starvation parties, no food or drink was served (other than the "amber-hued water of the James"), and only amateur music was allowed to entertain the crowds of ladies, gentlemen, and officers who danced the night away in their most fashionable finery. Prior to the first meeting of the Starvation Club, the group purportedly dispensed a committee of girls to seek the permission of General Lee for such gayeties. "If you say no, general, we won't dance a single step," they promised. However, according to Cary, Lee readily approved of the gatherings, stating, "why of course my dear child. My boys need to be heartened up when they get their furloughs. Go on, look your prettiest, and be just as nice to them as ever you can be!"155 With the General's permission — and public justification for the starvation parties - the ladies quickly set to work in organizing their first events.

Richmonders hailed these celebrations as necessary political and social gatherings in support of some of the Confederacy's finest heroes. As noted earlier, many of these women's other dinners and social entertainments also focused around the entertainment of specific officers and politicians, such as General Hood and a handful of Confederate senators. The reception for celebrated Confederate raider John Hunt Morgan in January of 1864 proved especially extravagant, with large crowds of Richmond's most respected elites, such as Constance Cary, Mary Chesnut, and the Preston sisters gathering in their finest lace, diamonds, and feathers for an elaborate dinner and private theatricals at one of the city's most elegant mansions. These gatherings, the ladies firmly believed, might help to inspire those leaders to achieve victory on the battlefields and renew the city's dedication to the war effort, all while reaffirming the power of the Confederate capital's ruling class to help secure success on the field and the preservation

\footnotetext{
155 Harrison, 150.
} 
of social order at home. ${ }^{156}$

As the war continued, Richmond's ladies came to view the war's duration and the stress it placed upon all members of society as a serious threat to the morale, cohesion, and endurance of the ruling elite. Without the elites' charity, moral guidance, and general aid in reinforcing social and class order in society, they feared, Richmond would fall to pieces, and the outcome of the war wouldn't so much matter anyway. Furthermore, if the war were to lose the support and faith of their ladies in the success of the Confederate cause, what would prevent others from losing heart as well, and what would stop the ensuing social and political mayhem from breaking loose? As a class of individuals who were used to certain comforts and privileges, the capital elite thus feared that a complete disavowal of those comforts would chip away at the strength of the foundational leaders upon whom the pillars of society rested. Their indulgence in parties, they therefore believed, was both a social privilege but also a political responsibility.

In particular, the leading ladies held up private theatricals as politically justified social gatherings that helped to provide a necessary sense of cohesion and uplift amongst Richmond's ruling class. By performing for-and even with — some of the most prominent war heroes and political leaders of the Confederacy in private tableaux, charades, and mini-dramas, elite women saw themselves as performing an essential political duty for their male protectors by helping to entertain them and raise their spirits. ${ }^{157}$ However, they also viewed these male leaders' presence as justification for the continuation of a long-cherished cultural ritual that helped to bond members of the leading class together. Such close bonding, they believed, would result in more effective and powerful male and female leadership, and would enable the mentally taxed male leaders to escape from the strains of reality for a few short hours so that they might be able to 
perform their stressful duties better in the future. "Such was the dramatic side of Richmond society,” T.C. DeLeon spoke of these private house parties. “...[A] side that lit the leaden gloom that slowly began to weigh upon the spirits of even the most hopeful; lightened the labors of hospitals and...kitchen drudgery; made furloughs red-lettered with memories of bright faces, sweet voices, and airy forms." ${ }^{158}$ Wealthy Mary Tucker Magill likewise praised these gatherings as a much needed "oasis in the deserts of our minds."

And so, throughout the war, but increasingly so during the most challenging last year and a half of war, Richmond's ladies threw themselves into their work as hostesses, performers in, and attendees of some of the city's most famous war-time theatricals. ${ }^{160}$ Numerous days of rehearsal and long hours of preparation preceded each of these highly ritualized performances. ${ }^{161}$ In January, 1864, Mrs. George Randolph asked Constance Cary to help her arrange an evening charades party for "official Richmond" at which no extravagance was spared. Ladies performed in their finest jewels, spangles, and scarfs donated by various friends aside Generals J.E.B. Stuart and Fitzhugh Lee. Cary herself arrived outfitted in white ostrich plumes given to her by a neighbor, powdered locks, and a pearl necklace. Music and painted backdrops added to the performances of charades featuring the words "penitent, harem, and matrimony." These lighthearted gatherings served simultaneously to entertain, stimulate the mind toward intellectual rather than military thought, and restore a sense of familiarity and normalcy to those in attendance, including the President, his cabinet, and other "official people." 162

Later that winter, Virginia Clay won her audience over in a comedic theatrical entitled

\footnotetext{
158 DeLeon, 233.

159 Macgill, 345.

160 DeLeon, 217, 232.

161 Chesnut, 536-7.

162 Harrison, 173, 176.
} 
"The Rivals" with her dramatic role as "Mrs. Malaprop." Constance Cary played the foil to Mrs. Malaprop and shared the stage with Postmaster General John Reagan and numerous Confederate generals who made the audience roar with laughter during their performances. The comedy was so popular, in fact, that it played for two straight nights. Cary proudly wrote of the numerous costumes that she compiled for her role, which included a white muslin dress, a lace negligee cap, blue ribbons, a petticoat and bodice of pale blue brocade, lace, and a pink rose head wreath. ${ }^{163}$ Meanwhile, Virginia Clay wrote nostalgically of the "galaxy of talent and beauty in that fairest city" that donned the elaborate costumes that had formerly been worn by "distinguished ancestors in the days of the Old Dominion.",164

Clay's focus on the ways in which the theatricals recalled the glory and distinction of prewar Richmond illustrates the empowering, inspirational, and yet calming influence of these minidramas upon the anxious minds of the city's social guardians. The influence of the theatricals upon the spirits of the capital elite was so great that "no efforts were spared in rehearsals or preparation of the wardrobe," Clay wrote. In fact, Clay even noted that, in order to ensure the success of each performance, the ladies invited players from a local theatre to give the stars of the show private consultation and criticism. ${ }^{165}$

The dedication of Clay, Cary, and their peers to creating lavish velvet, lace, feathered, and flowered costumes and scenery for these routine theatricals might seem strange when both Richmond and the Confederacy as a whole were feeling the extreme miseries of war during the winter of 1864 . However, as mentioned above, both Clay and Cary themselves commented on the inspiration and long-absent feelings of joy that they received from such entertainments. For

163 Harrison, 177, 178

164 Clay-Clopton, 174.

165 Clay-Clopton, 176. 
Richmond's leading ladies, these light-hearted gatherings provided a reminder of life before the onset of war- a life that they felt it was their duty to protect as the social and moral guardians of the city.

However, the theatricals also provided a much-needed, temporary relief from the strains that they constantly felt as those social and political leaders of the Confederate capital. As Drew Gilpin Faust has noted, the theatricals enabled women to temporarily assume the identity of another, and, in doing so, free themselves of the cares and worries inherent in the lives of the female capital elite. Additionally, the theatricals provided Richmond's ladies with a safe, socially acceptable forum in which they might practice tweaking or re-crafting certain elements of their own personalities, "in life as in theater," that would allow them to adapt more easily the needs and social pressures of war-time society. ${ }^{166}$

Again, it is easy to dismiss the ladies' "concerns" about both their own mental health and that of their male protectors as insincere; however, in the minds of the capital elite, light-hearted social gatherings helped to maintain certain privileges and luxuries that were essential to the maintenance of the ladies' morale, social identity, and authority. Sallie Putnam believed that it wasn't the poor class at all who was the most "inconvenienced" by the war or who endured the most misery, but rather the "real sufferers" were actually the "most worthy and highly cultivated of our citizens...who were compelled to seek [shelter] in the crowded city....How great their necessity must have been," Putnam wrote, lamenting the plight of some of her fellow ladies who, "reared in the utmost ease, delicacy, and refinement were compelled to dispose of all articles of taste and former luxury and frequently necessary articles of clothing to meet the everyday

166 Faust, 227. 
demands of life." ${ }^{167}$ Putnam clearly believed that the war placed a much greater physical and mental burden upon those who had once known luxury and ease, but had seen both snatched away by war, than it did upon those who were "used to" a perpetual life of suffering and sacrifice. Furthermore, the leading ladies viewed their more luxurious lifestyles as not at all extravagant or selfish by comparison with the "gaudy, greedy" lifestyles enjoyed by certain outlying social sectors, such as Richmond's Jewish speculators and other extortionists about whom the general public complained routinely. ${ }^{168}$

As the beleaguered First Lady of the Confederacy, Varina Davis repeatedly highlighted both the personal and the political need for social amusement during the war. As early as the summer of 1861, Varina lamented the strains which serving as the social hostess and First Lady of the fledgling new nation were placing upon her. "I live in a kind of maze," Varina confided to Mary Chesnut. "How I wish my husband were a dry goods clerk. Then we could dine in peace....this dreadful hour of living day to day depresses me more than I can say." ${ }^{169}$ By late 1864, Varina was so depressed by the state of things in Richmond and by the progress of the war that she wrote despondently to Mary Chesnut, "I must confess, I do not snuff success in every passing breeze, but I am so tired—hoping, fearing, and being disappointed...I try not to be disconsolate, even though thieves break though and steal." ${ }^{\prime 10}$

Because Varina served as such a critical social and political pillar of Confederate Richmond, her despondency was particularly troubling to her peers. Even Jefferson Davis had to constantly remind her to mask her sadness, as displaying such discouragement would be a huge

\footnotetext{
167 Putnam, 343, 208-210.

168 Putnam, 272; McGuire, 300-303.

169 Sarah E. Gardner, Blood and Irony: Southern White Women's Narratives of the Civil War, 1861-1937 (Chapel Hill: The University of North Carolina Press, 2006), 23.

170 Cashin, 119, 126-28.
} 
blow to the morale of the Confederate nation. ${ }^{171}$ LaSalle Corbell Pickett, a frequent guest at Varina's receptions, wrote that, if it were not for Varina's light-hearted parties, both the morale of the female capital elite and the effectiveness of their men to successfully govern both the nation and the war would have been dangerously low. Praising the parties for diverting the minds of the elite — including President Davis—-from the daily toils and growing anxieties of war, Pickett exclaimed, "how could we live on the rim of a volcano if we could not dance around its crater?"172

Similarly, in January of 1864, Mary Chesnut justified her continued party-going, explaining to a friend that "hope and fear are both gone. And it is distraction or death with us. I do not see how sadness and despondence could help us." ${ }^{173}$ In response to the increasing fear and anxiety that threatened to cripple Richmond's political and social leadership, the extravagant parties of the capital elite continued right up until the end of the war, with some of the most lavish entertainments occurring during the winter of 1864-1865. Young, well-to-do Kate Rowland noted that, upon receiving word of the Fall of Fort Fisher, in North Carolina in early January of 1865 , the city grew intensely gloomier, demanding some kind of emotional release for its pent-up anxiety. Thus, Rowland wrote on January 23, 1865, that "last week was one of usual gayety." Rowland described the many elaborate parties and dinners that she personally attended during that week alone:

We went to a party at the C.'s---quite a grand affair. Captain Semmes of the Alabama-chief of the celebrities - was present. Generals Kemper and Mitchell, the Irish patriot [also among them.) Dancing and music, vocal and instrumental, filled up the evening. Night after night, Lizzie and Aunt Emily accepted an invitation to the Randolphs' and got a glimpse of the gay world of Richmond. The supper was as elegant and profuse as in good times and must have cost an

\footnotetext{
171 Cashin, 126-9.

172 LaSalle Corbell Pickett (Mrs. Gen. George E. Pickett), What Happened to Me (New York: Brentano's, 1917), 142; La Salle Corbell Pickett (Mrs. Gen. George E. Pickett), Across My Path: Memories of People I Have Known (New York: Brentano's, 1916), 13.

173 Chesnut, 539.
} 
immense amount of Confederate script. General Longstreet was there and Semmes again — the modest...pride of our infant navy... ${ }^{174}$

Rowland even recorded enjoying a "very pleasant evening at General Breckinridge's," complete with some beautiful music — vocal and instrumental" on the evening of April 1, 1865-the evening before the fall of Richmond! ${ }^{175}$

In a continued effort to jointly raise their own morale and support for the Confederacy, and to bolster that of their soldiers and politician husbands, Richmond's leading ladies also participated in numerous day-trip parties to nearby Drewry’s Bluff, a combined naval, army, and marine outpost often referred to as the "Gibraltar of the South." In May of 1862, the small, hodgepodge group defending Drewry's Bluff had won a critical and miraculous victory when they prevented the ironclad USS Monitor and four other United States Navy ships from slipping up the James River to bombard the Confederate capital. Following the May, 1862 Confederate victory, Drewry's Bluff instantly became a symbol of Confederate pride and hope for an ultimate southern victory. A newly established, sizable garrison at Drewry's Bluff established an impressive little village atop the bluff that boasted, among other buildings, a chapel, a hotel, a masonic lodge, a post office, and a large parade ground. ${ }^{176}$ The city of Richmond dedicated one of its steamers, the Schultz, to running twice-daily trips to the bluff for the benefit of curious civilians.

The proud little village attracted thousands of visitors per year, but was particularly popular among the Richmond ladies, such as Mary Chesnut and her "court" who were greeted at the Drewry's Bluff docks by Robert E. Lee's brother, Captain Sidney Smith Lee, Secretary of War Stephen Mallory, and Senator Clement C. Clay, and then escorted up to the parade ground

\footnotetext{
174 Kate Rowland diary, entry for January 23, 1865, Kate Rowland Papers, Civilian and Home Front Collection, Eleanor S. Brockenbrough Library, Museum of the Confederacy (Richmond, VA), 144-5. 175 Kate Rowland diary, entry for April 2, 1865, Kate Rowland Papers, Civilian and Home Front Collection, Eleanor S. Brockenbrough Library, Museum of the Confederacy (Richmond, VA), 147.

176 Richmond Daily Dispatch, May 1, 1863.
} 
to receive a tour of the defenses. The ladies often contributed to an elaborate picnic luncheon (or two) for themselves and for their soldier escorts, and watched with pride as the troops walked through their drills on the parade field. ${ }^{177}$

These trips to the bluff continued to place Drewry's Bluff and the Confederates' unlikely early-war victory there in the spotlight and in the minds of local Richmonders, many of whom were inclined to balk at the abilities of the Confederate military during the bloody years of late 1863, 1864, and 1865. By making frequent, heavily publicized trips to the Bluff, the leading ladies were making as much of a political statement as they were a social one. On a public level, the ladies hoped that their conspicuous comings and goings on the Schultz in support of the garrison on the bluff would serve as an inspiration for the general public likewise to remember the brighter days of the Confederacy. In doing so, the public would be more inclined to keep enduring, sacrificing, and remaining loyal to their leaders who were entrusted with ensuring the ultimate success of the Confederacy. On a personal level, the ensuing gayeties in the camp helped both to boost the morale of the ladies and the soldiers encamped at the bluff and to reinforce each group's dedication to and belief in the ultimate success of the Confederate cause.

In addition to the trips to the bluff, Richmond's ladies occasionally partook in relaxing moonlight river cruises along the James River with a select group of high-ranking generals and politicians aboard the steamer Allison. As both entertainment and social reinforcement, the cruises helped to boost the spirits of Richmond's ladies and leading gentlemen and promote a necessary sense of solidarity among the ruling class. These cruises often took the form of elegant parties and cotillions to which only "select and orderly guests" were invited. Guests

177 Chesnut, 480; Harrison, 126. 
indulged in music, dancing, and "catered oysters, crabs, meats, fruits, ice cream, and the choiciest of liquors" from the Exchange Hotel. ${ }^{178}$

The capital elite enjoyed these "carefree" river cruises as yet another reinforcement of the power and privilege of their social position. However, they also hoped that these "state cruises" might showcase before the public a "vibrancy" in the Confederacy and a calm confidence of the ruling elite in the ultimate success of the war. It was crucial for the capital elite to project such confidence in the outcome of the war in order to combat the inclinations of the city's more pessimistic and frustrated commoners (often called "croakers") toward destructive and depraved behavior that frequently occurred during the darkest times of the war. ${ }^{179}$ With the Confederacy's leading men and women bedecked in their finest evening apparel, calmly enjoying a night of entertainment and sight-seeing, the moonlight parties would have made quite an impression on those watching from the riverbanks or those reading the reviews of such events in the local newspapers. Seemingly unaware of how the publicity of such lavish river cruises during some of the most somber days of the war might, in fact, produce increased frustration and disillusionment with the war and its elite proponents, the leading ladies whole-heartedly welcomed the opportunity to celebrate some of their finest war heroes while indulging in perceptibly "necessary” wartime diversions and elaborate socio-political statements.

Richmond's leading ladies also indulged in an array of general's receptions, private theatricals, and wartime weddings under the justification that such events were critical to the health of the Confederacy and its leaders, and to Richmond's precarious social order. Furthermore, Richmond's elite women believed that these lavish performances of adapted antebellum cultural rituals provided a necessary restoration of a sense of tradition and normalcy

\footnotetext{
178 Richmond Examiner, August 18, 1864; Harrison, 126.

179 McGuire, 109, 111.
} 
to the war-ravaged city. By emphasizing the continued ties with the pre-war order and social customs in the Confederate capital, even in the midst of the bloody conflict, elites hoped to provide a sense of calm and familiarity amongst city-dwellers. The ladies hoped that, in doing so, Richmond's commoners would be reminded of the "good old days" and thereby continue to rally around restoring the traditions and order of antebellum society while simultaneously pledging their continued support to the Confederate cause.

One particularly "comforting" ritual in which Richmond's ladies continued to participate on a surprisingly regular basis was the wartime wedding. Numerous, exclusive weddings between officers and Richmond's most admired belles occurred throughout the war and routinely incited the feverish excitement of the city's fellow leading ladies. Regarded as both a familiar reminder of peace, love, beauty, and the celebration of life for Richmonders of all classes, and yet another unifying, uplifting, and class-affirming ritual for the elite in particular, wartime weddings garnered the attention and awe of poor and wealthy alike. Crowds of "curious spectators" frequently gathered outside both the churches and the homes of Richmond's wartime brides, eagerly hoping to catch a glimpse of the exciting festivities or the elegant beauty of the bride. ${ }^{180}$ Even the homemade bridal gowns, comprised of old curtains and table lace, brought admiring crowds out to the streets. ${ }^{181}$ Richmonders were so excited by a big wedding that they often flooded the various city churches in an effort to share in the celebrations. Mary Chesnut noted of one wedding that, at the church, "people pushed and shoved us, and at first we thought they had more right to be there [than us], but we then found one man who didn't even know what wedding it was!"182 Likewise, T.C. DeLeon observed that "St. Paul's Church was the church of fashion, with many a swell wedding... and the crush of the curious was great.” On certain

\footnotetext{
180 Chesnut, 448.

181 Chesnut, 456.

182 Chesnut, 597.
} 
occasions, he noted, "conduct was more panicky than pious, and flirtation raged with giggles, sighs, and jest." ${ }^{.183}$

The light-hearted weddings provided the general public with at least a few moments of fleeting happiness and positive entertainment that might help to take their minds off of their sufferings, frustrations, and any thoughts of rowdy behavior that might serve as an outlet for such sufferings or depression. ${ }^{184}$ They also continued to foster a sense of awe and admiration for the elite stars and attendees of the weddings who seemed more like theater celebrities than the "ruling class" on such fancy occasions. Encouraging such awe for elite power and privilege was a critical component in garnering and maintaining both the loyalty and good behavior of the lower classes.

From Lucy Haxall to Maria Freeland, La Salle Corbell to Hetty Cary, the city's most beautiful belles provided Richmonders with a genuine reason for celebration through highly publicized weddings that temporarily shielded Richmonders from the dark clouds of war and offered — if only temporarily — tidings of happiness, peace, love, and normalcy, qualities whose presence many had not felt since the early days of the war. ${ }^{185}$ Dressed (for the most part) in elaborate gowns and elegant jewelry, the brides-to-be dazzled Richmond with their beauty and grace. Many of Richmond's leading matrons donated their last pieces of lace, a strand of pearls, or even their carriage to the brides-in-waiting, thus both privately reaffirming their approved acceptance of the belles into adult ladyhood, and physically contributing to these highly publicized—but exclusively attended—rituals of celebration. ${ }^{186}$

183 DeLeon, 373

184 DeLeon, 373.

185 Putnam, 342.

186 Chesnut, 492; Harrison, 202. 
Highly conscious of her "stage presence" as one of Richmond's most celebrated war brides, LaSalle Corbell had her bridal dress — an assemblage of old gowns remodeled from 100year-old court robes, home woven frocks, vegetable-dyed clothes trimmed with seeds, laces from fine spun flax, crocheted trimmings, and peach stone buttons - specially imported through the lines. Additionally, she directed her servants to sew silk milkweed balls and pink roses onto the brim of a new bonnet to wear to and from the church, and completed her wardrobe with a white satin wedding robe with shimmering lace, "made at a center of fashion."187 Awing the crowds that gathered on the streets to see the wedding procession, LaSalle Corbell's lavish wedding to Confederate icon, General George Pickett, served as one of the greatest social events of 1863 , but also helped to spur the spirits and the loyalties of Richmonders of all classes to the celebration of the Confederacy's war heroes and their social guardian wives. Following the wedding, guests were invited to an exclusive reception, featuring terrapin stew, turkey, and fruit cake, among other delicacies, where the elite retired to socialize, dance, and cheer their own spirits with all of the luxuries afforded to them by their unique social standing. ${ }^{188}$

Interestingly, in a conspicuous gesture of benevolence and "sisterhood," LaSalle decided to donate her dress to her fellow belles of Richmond for future use throughout the war. "Possession of a real wedding dress was a distinction that carried with it a sense of obligation to the community at large," Mrs. Pickett later wrote, "so my bridal gown graced a number of weddings after."189 Pickett's sharing of her dress with other Richmond brides was a clear expression of the sisterly bond that Pickett hoped to extend to and share with her fellow young leading ladies. In sharing her dress, Pickett was consciously re-creating the reciprocal social

187 Pickett, What Happened to Me, 130-31.

188 Pickett, What Happened to Me, 128.

189 Pickett, What Happened to Me, 131. 
relationship of her elders, who, as noted earlier, often shared their clothes, jewelry, food, furniture, and homes with other ladies for the common benefit, comfort, and cohesion of the ruling class. In transferring these practices to the young women of her own generation, Pickett helped to strengthen the bonds of young ladyhood amongst her peers - the future social leaders and moral arbiters - who were already being called upon by their elders in helping to restore order and respectability to their war-ravaged society.

No wedding proved more popular and symbolic than that of Hetty Cary, however. Occurring on January 19, 1865 at Richmond's St. Paul's Church, Hetty Cary's marriage to native son and military hero General John Pegram was one of the single most celebrated social occasions in Richmond's Civil War history. Well-known as Richmond's most gorgeous and charming belle, Hetty Cary had long represented the epitome of beauty, grace, innocence, and moral ladyship. Her contributions as a flag seamstress and as a dedicated hospital worker distinguished her as one of the most patriotic young ladies of the South, and her impressive social skills, both as hostess and attendee of various exclusive parties and gatherings, set her apart from her peers. Hetty's engagement to the beloved and highly respected John Pegram only reinforced her standing as Richmond's most highly esteemed and most influential young lady.

Hetty's celebrated 1865 wedding brought hope and temporary peace for all of Richmond society, even during a time when, for many, it seemed like hope was all but gone for the Confederacy. Despite the miseries and suffering that now ran rampant throughout besieged Richmond, the Cary-Pegram wedding offered a glimmer of normalcy, a symbol of the continuation of life, and the hope of future happiness. And so, as Constance Cary recalls, "on the evening of January 19, our little world flocked to St. Paul's to see the nuptials of one called by many the most beautiful woman in the South with a son of Richmond [who was] universally 
honored and beloved...The congregation crowded the floor and galleries..."190

Mrs. Davis, a great admirer of Hetty, lent the young bride the Presidential carriage to transport her to the church. Upon the arrival of the "noble looking couple," Hetty proceeded slowly down the aisle in a beautiful tulle veil to the "murmur of delight" of the crowd who had never before seen a "beauty more striking." To Constance Cary, Hetty_-"pearly white" in complexion, with "roses on her cheeks and lips," and lace hankie in hand-and her "brown eyes seemed to defy all sorrow, change, or fear."191 For Cary and other spectators, the world seemed to stop if only for a few moments during Hetty's wedding. The celebration's positive impact on Richmonders was infectious and undeniable. ${ }^{192}$

Sadly, however, Richmonders ultimately remembered the Cary-Pegram wedding as an embodiment of the false hope and tragedy that defined the final few months of the Confederacy's life. Just three weeks after the wedding, John Pegram was killed at the Battle of Hatcher's Run, just outside Petersburg. His body arrived at St. Paul's and was carried down the same aisle over which his new bride had processed before the eyes of Richmond less than one month before. Reverend Minnegerode, who had officiated the wedding, officiated the funeral while a mourning crepe-draped Hetty and weeping crowd of spectators - many of whom had celebrated the joyful event of the previous month-looked on. ${ }^{193}$ Like the wedding, the funeral was publicized in the local newspapers and recorded in numerous Richmonders' diaries, but this time it symbolized the impending demise of the Confederacy, its cherished social traditions, and the unique way of life for which southern soldiers and Richmond's ladies had desperately fought for four long years to

190 Harrison, 201.

191 Harrison, 202.

192 Putnam, 342.

193 Harrison, 203. 
preserve. Hetty's cousin, Constance Cary, described the scene:

Three weeks later, to the day, General Pegram's coffin, crossed with a victor's palms beside his soldier's accouterments, occupied the spot in the chancel where he had stood to be married. Beside it knelt his widow swathed in crape.....again the church was full...the wailing of the band that went with us on the slow pilgrimage to Hollywood [Cemetery] will never die out of memory. ${ }^{194}$

At the end of March, for both Constance and for Richmond society, General Pegram's tragic death, combined with that of Hetty's brother-in-law Colonel William Pegram outside Petersburg just weeks later, "hope in the stoutest spirits seemed to flicker but feebly and the ultimate failure of the Confederacy seemed to be a foregone conclusion." ${ }^{, 195}$

Whether Richmond's ladies' efforts toward achieving and maintaining the city's traditional social order during the war itself ultimately succeeded or not, their actions-right up through the spring of 1865 - clearly reveal a forceful attempt at preserving what soldiers on the battlefield and politicians in the Congress ultimately could not. However, even when following the rules of engagement and the edicts of necessary social engagement, many of Richmond's ladies became the prime target of sharp criticism from both their peers and the general public. In fact, both historians and war-time contemporaries, such as members of the male capital elite, young Richmond's “boy colonel” and artillerist Willie Pegram, Chimborazo hospital's chief matron and native South Carolinian Phoebe Pember, and the editors of the dry-witted newspaper Southern Punch, have blankly criticized Richmond's ladies for the seemingly inordinate amount of time and energy they spent preoccupied with organizing elaborate social events, and particularly with the crafting of their own appearance at such gatherings. These critics were especially vocal in their complaints during the latter portion of the war when inflation, shortages,

194 Harrison, 205.

195 Harrison, 205. 
and poverty ran rampant in the Confederate capital.

While the Richmond elite clearly continued to enjoy luxuries and privileges on a much larger scale than did most other Richmonders from the lower classes, it is undeniable that even members of the uppermost echelons of society were forced to scale back their lifestyles in (proportionately) noticeable ways during the war. The myriad problems of inflation, shortage, impressment, and speculation within the Confederate economy; the Union blockade's eventual stranglehold over the South's primary coastal cities; as well as the raw military reality of the Union army's near encirclement and isolation of Richmond from the rest of the South by late 1864, prevented anybody from continuing to live as comfortably and lavishly as they once did before the war, no matter how wealthy or well-connected they might have been. Sallie Putnam explained this phenomenon perhaps the best, stating, "We sometimes hear of those who didn't 'feel the war'...I don't know what that means...[The war was] physically and mentally felt by all...we all shared in common distress, there was no wardrobe or table that didn't reflect the war." If some homes had "comforts and elegances," Putnam went on, one only had to "step out and see the rest of the mangled soldiers, the poor women waiting for coarse sewing work; the refined and elegant daughters of luxury now at work in the Departments." Putnam firmly believed that, unless "feeling was... dead within the soul, if the sensibilities were not benumbed by extraneous influences, there was no one in our Southern land who did not feel the war."196

Nevertheless, both public and private vitriol against Richmond's leading ladies flowed in the city newspapers, diaries, and memoirs of the war. The Richmond Examiner, edited by the fiery and unpopular Major John Daniel, repeatedly targeted the well-dressed ladies of the capital elite—especially Varina Davis and Mary Chesnut—for their overly lavish dresses of "sage green 
velvet and diamonds," accusing Varina's "court" of wearing far more exotic finery than anyone else in the capital. An avid critic of Jefferson Davis and his administration, John Daniel thought both the President's cabinet and their wives to be quite snobbish and overly aristocratic during a time of civil war. ${ }^{197}$

In August of 1863, a new, satirical, but brutally honest Richmond periodical called the Southern Punch, lamented the extravagance displayed by the upper classes, even at the most basic of social occasions: "Our republican simplicity, before the Revolution, gave way to... aristocratical notions based upon cash. Fire and carnage have not dissipated these follies. And so, Worth and Intellect look tearfully upon the present of our fashionable cities as Lot looked upon Sodom and Gomorrah."198 The Punch expressed particular disdain for the well-todo refugees who continued to flood the Confederate capital and who expected man and woman alike to immediately bow down to their wealth and material distinction. The periodical reported,

[Punch] has no respect for bad imitators of the Virginia gentleman and lady of the olden time; misguided people, who think themselves to be aristocratic, they must be peculiarly exclusive and publish themselves accordingly. We have not the desire to belong to their 'set;' nor wish to enter their prison-houses... They do not represent the Virginian proper.

Rather, the Punch praised the more in-touch "people who acknowledge [us] on strolls...who...in this era... has not obliterated all humanity...such souls, unlike Mr. and Mrs. Exclusive, sympathise with the weary...poorly clad soldier, and go with him in spirit to the hospital and the field, instead of constantly courting the society" of Richmond's most elite socialites. ${ }^{199}$

As the war dragged on and the sufferings within the Confederate capital increased, the Punch grew particularly antagonistic toward Richmond's well-to-do women who, more than

197 Chesnut, 439-40.

198 Southern Punch, August 15, 1863.

199 Southern Punch, August 15, 1863. 
ever, appeared completely preoccupied by selfish, simple-minded materialism. A January 23, 1864 edition of the Punch drily remarked: "In a woman's life everything leads to a new dress, everything ends with a new dress, every circumstance is marked by a new dress, and dress is always the most important point. ${ }^{.200}$ The Punch continued its vitriol against Richmond's ladies in November of 1864, following the unprecedented bloodiness of the year's spring and summer campaigns, with a particularly scathing editorial about a lady's selfish conception of pleasure during such a solemn time. "Ask a woman what is happiness," the Punch stated disgustedly, 'and she will respond: 'a velvet dress, with fourteen breadths to the skirt;' how many women have been ruined by diamonds," the Punch lamented, when their attentions should have been focused on mourning the hundreds of thousands of southern dead and assisting the thousands more poor and destitute refugees who wandered the city streets in abject misery! $!^{201}$

Wistful for the familiar and traditional social hierarchy of the pre-war days, the newspaper editors were also particularly resentful toward these "single-minded" women for their attempts at a meteoric rise to social prowess, sharply reminding them that "the stepping stone to fortune is not to be found in the jeweler's shop." The Punch bemoaned the rampant spread of such infectious zealousness, noting that an individual's worth now appeared to be measured only in terms of his material offerings. The periodical scorned the fact that "some women have hearts brittle as glass, and he that would engrave his name must use diamonds" in order to receive the attention of a lady, who often would "only listen to your suit if you first give her an earring" or emerald. $^{202}$

Worse yet, the periodical argued, women's over-adornment and excessive ornamentation undermined the sense of trust between individuals who frequently confused so-called "ladies" for

\footnotetext{
200 Southern Punch, January 23, 1864.

201 Southern Punch, November 8, 1864.

202 Southern Punch, October 10, 1863.
} 
prostitutes or other social imposters. How was one to discern a true lady from a potentially threatening and immoral social pretender when a lady insists on "shoe dye[ing] [her] locks like a desperate gambler mak[ing] [her] last venture, risk[ing] all upon a dye?" the Punch questioned. ${ }^{203}$ Furthermore, the editors of the Punch feared, the ladies' insistence on flaunting their extravagant attire ultimately undercut the public's respect for and loyalty to the capital elite by creating more anger, jealously, and distance between the "have nots" and the "haves." The editors conveyed their embarrassment over the daily displays along the city's major thoroughfares, admitting, "we blush at the exhibition of female deficiencies which are constantly to be seen on the streets in Southern cities....we cannot believe that Eve caused so much foolish death, sin and crinoline."204

Even "Agnes," a wealthy woman only identified by her first name in the diary of her distinguished friend Sara Pryor, rebuked the women who never ceased to request new bonnets and dresses from the blockade. "We have no right at this time to dress better than our neighbors," Agnes wrote to Pryor in August of 1863, "and besides, the soldiers need every cent of our money." ${ }^{205}$ Agnes wrote disapprovingly of Union Admiral David Porter's capture of a blockade running ship, in whose cargo he was shocked to find piles of bonnets with names attached to each one - French bonnets, cloaks, shoes, all items which, Porter declared, "he thought southern ladies sent...to hospitals...and never spent a cent on themselves!"206 Agnes proclaimed that she had become so anti-materialistic that she would "costume myself in coffee bags if that would help, but having no coffee, where would I go for bags?"207

\footnotetext{
203 Southern Punch, November 8, 1864.

204 Southern Punch, October 10, 1863.

205 Mrs. Roger A. Pryor, Reminiscences of Peace and War (New York: The Macmillan Company, 1905), 226.

206 Pryor, 313.

207 Pryor, 313-314.
} 
However, it is interesting to note that Agnes herself continued to attend high-profile social events, such as the regular Presidential receptions held at the Davis house, and that she, too, continued to obsess over her own appearance. In one letter to Sara Pryor, Agnes wrote particularly gleefully about the gray silk dress with eleven flounces that she wore to one reception, and her proud re-crafting of an old gray silk bonnet with freshly washed and ironed dyed blue lilies. $^{208}$ With her own social reputation to maintain through impressive appearances at social gatherings, Agnes proved Admiral Porter right in his summation of cargo aboard the blockade running ship, that "human nature is the same though, and ladies will indulge in little vanities in spite of war.,"209

In addition to being critiqued for their manner of dress, Richmond's ladies also received nearly constant criticism both from within the home and from the broader public for the elaborate nature of the social functions with which, to certain individuals, they seemed nearly “obsessed." The Richmond Examiner took aim at Richmond ladies' preoccupation with social extravagance, angrily noting on December 2, 1863 that "while the men suffer in the fields, money is spent faster than in flush times---balls, parties, drink, dance, and be merry regardless of the numbers pouring out their blood." The paper even went so far as to indict the numerous officers in Richmond that winter who were "whirling around, making merry at the theatres." The editors of the Examiner did not believe that these festivities reflected any larger social intentions other than allowing the elite to entertain and indulge themselves. Thus they ultimately viewed the continuous waves of costly amusements as not only inappropriate, but as downright dangerous to society and to the Confederacy as a whole. They solemnly cautioned their readers, "this state of things cannot last always. The intoxication we are now laboring under will be

\footnotetext{
208 Pryor, 226.
}

209 Pryor, 314. 
followed before long by a season of prolonged depression when the cost comes to be computed." 210

Neither were the editors of the Richmond Examiner convinced that the active social calendar of the Richmond elite would contribute in any positive way to the upholding of social order. Following a particularly gay winter in 1864, the Richmond Examiner pleaded with its readers to stop the "carnival of unhallowed pleasure" that had reigned in Richmond earlier that season. "This winter has witnessed many shameful displays of indifference to national calamity," the paper stated, noting that, while General Lee's army suffered from starvation and cold out on the battlefields, and while starving women flooded the office of the local YMCA on a daily basis, the Richmond elite spread "sumptuous suppers before their already well-fed neighbors, and danced with joy and delight." In the opinion of the editors, both the elites' hording of much needed supplies for their own gratification, and their continued indulgence in gayety and "frivolity," while their defenders, friends, neighbors, and sometimes even family members were suffering and dying by the thousands, seemed a shocking and sinful "mockery of the misery and desolation that covers the land."211

The editors of the Enquirer were so disgusted by the ladies' reckless frivolities that they began to compare Richmond's "sinful frolics" to those that permeated and degraded Northern society. In a particularly caustic conclusion, the paper event went so far as to compare that 1864 winter in Richmond to the fall of Rome and condemned what they believed to be the elites' utter indifference to death: "The parallel of dancing and fiddling while Rome was burning has been seen in Richmond during the winter. We sincerely hope it has run out," the editors wrote. They

\footnotetext{
210 Richmond Examiner, December 2, 1863.
}

211 Richmond Examiner, February 12, 1864. 
also lamented how much Richmond's response to mass tragedy had changed since the early part of the century. They reminded readers of how, following the great Richmond theatre fire of 1811, Richmonders had nobly "banished gaiety from its society for many seasons" in an appropriate mourning tribute to the thirty lives lost during that calamity. The editors disparaged the fact that now, just some fifty years later, so many of Richmond's supposed leaders and models of morality blindly waltzed on every evening, seemingly laughing in the face of the hundreds of thousands of soldiers and civilians who had died since the beginning of the war. ${ }^{212}$

Unsurprisingly, Mary Chesnut received particularly pointed criticism from nearly every direction for her own zealousness for parties and social gatherings. While dressing one evening for a high-society party during the winter of 1862-63, Chesnut's own slaves lashed out at what they called her "sinful frolicking." "Well, we have had our frolic too," they stated angrily, "Anne and me are going to do all of our clear starching and ironing in here when you are out of our way."213 Over time, even Mary Chesnut's own husband critiqued her frequent social gatherings and her preoccupation with her appearance. Initially accompanying Mary and her "court" to various breakfasts, parties, and teas, in the winter of 1862-63, Mary's husband ultimately "broke down and denounced us for being so dissipated." In 1863, Mary happily wrote that, much to her relief, Jefferson Davis finally "came to our rescue" and sent Mr. Chesnut off to Charleston to report on the conditions in that city, where he would be unable to criticize Mary and her lady friends for their social antics. ${ }^{214}$

However, in December of 1863, upon returning to Richmond, Mr. Chesnut continued to lecture Mary about her numerous public appearances. One evening, James arrived home

212 Richmond Enquirer, February 12, 1864.

213 Chesnut, 431-2.

214 Chesnut, 430. 
unexpectedly during a party that Mary had thrown in secrecy for her friends. Mary was so afraid of his scorn that she recalled "trembling" before his presence. The next day, James lectured a "penitent, subdued, and humbled" Mary about giving up her parties, stating that "the country is in danger, and there is too much levity here." ${ }^{215}$ However, the parties continued. Following another social engagement that December, Mr. Chesnut accused Mary of being "too extravagant" and called her "hospitality run mad." Meanwhile, Preston Hampton scorned Chesnut for renting out a twenty-five dollar per hour carriage to attend a theatrical that winter at Mrs. Stanard's, calling her spending "senseless extravagance" for "stupid charades."216

Mary Chesnut took great offense to the criticisms of her husband and to her peers' insinuations that her active social life was unrestrained and altogether too lavish. Well aware of the high personal and social stakes within which she was constantly operating in Richmond, Mary resented her husband's inability to understand the requirements of ladyship and the privileges inherent in elite ladyship. While her husband clearly defended his role as an honorable member of the capital elite through both his military and official political service, Mary argued, she and her peers were forced constantly to fight to retain their own honor and prestige through material and social means. Additionally, Mary and her scorned peers were angry and frustrated by the fact that their critics did not share their belief that their actions ultimately helped to improve the social and moral fabric of the broader community as much as they worked to the benefit of the ladies themselves. The women simply could not understand how the efforts that they put forth for what they believed to be the "betterment of all"-including the increased morale of the capital's leading men and women — could be perceived by others as driven by purely selfish motives.

\footnotetext{
215 Chesnut, 508.
}

216 Chesnut, 516. 
The ladies strongly believed that exclusive parties helped to maintain the familiar virtues necessary for effective and moral leadership — namely, refinement, grace and hospitality, as well as class cohesion, unity of purpose, and optimism. By extension, the ladies felt that their efforts would thereby reinforce their cultural authority to govern society. They also believed that their displays of those values might inspire and uplift broader elements of society to also embrace such virtues. Through such influence, the ladies believed they might help not only to "clean up" the morals and behavior of the general public, but that they also might help to establish a shared sensibility and a critical unity of purpose and determination amongst the unruly population of newcomers and strangers. Such a sensibility might inspire perseverance amongst Richmond's commoners to continue fighting and sacrificing for a lifestyle that they might actually feel was truly worth defending.

However, these naïve beliefs ultimately only deepened the cognitive dissonance between the ladies, their social inferiors, and their less materially focused peers, thus further alienating the ladies from the rest of society and heightening the public's sense of disaffection for the ruling class. For both the ladies' more sober-minded peers and the more critical members of the general public, true "respectability" (especially during a time of war) demanded the abnegation of all pretenses to wealth, elegance, and rigid class boundaries. The elites' critics felt that one's insistence on such claims actually weakened any sense of shared purpose and unity amongst the classes, sapped society of necessary material resources, and, in fact, deflated Richmonders' determination to keep struggling and sacrificing for a society in which social and economic inequities seemed only to be growing more prominent. By January, 1865, Judith McGuire wrote disgustedly of the joyous gatherings occurring on a regular basis in the Confederate capital:

Some people here seem crazed with gayety...In the midst of the wounded and dying, the low state of the commissariat, the anxiety of the whole country, 
troubles of every kind by which we are surrounded, I am mortified to say that there are gay parties given in the city.

McGuire gave greater leniency to the less indulgent starvation parties, where "young persons meet for innocent enjoyment and retire at a reasonable hour." However, she had no patience for the more elaborate festivities where "the most elegant suppers are served-cakes, jellies, ices in profusion, meats of the finest kind in abundance--enough to feed a regiment! I WISH these things were not so and that it all could go to the army," McGuire fumed. ${ }^{217}$

McGuire went on to describe her personal shock and disappointment with her peers when, while returning from a long day of hospital work after witnessing the heart-wrenching death of a brother in the arms of his sister, she passed a house wherein there was music and dancing. "The revulsion of feeling was sickening," McGuire wrote, bitterly. Comparing such distasteful and reckless frivolities with other such dangerous examples from history, McGuire commented: "I thought of the gayety of Paris during the French Revolution, of the cholera ball in Paris, the ball at Brussels the night before the battle of Waterloo, and felt shocked that our own Virginians, at such a time, should remind me of scenes we were wont to think only belong to...foreign society." McGuire feared that such scenes not only debased Richmond society, but also would weaken the fighting spirit of the Confederate army, which doubtless would think its own people "heartless" and unappreciative of their sacrifices. ${ }^{218}$

McGuire concluded her vitriol with a cut against the "perfect mania of matrimony" that seemed to have seized the city by late-war. Refusing to join in with other ladies in swooning over the elaborate weddings of Richmond's most elite members, McGuire was appalled to note that, "it seems that some churches are open and lighted every night for bridals!" How, she 
wondered, in the midst of all the wounded and sick men and impoverished refugees who required constant care and attention, did these crazed partiers have time for such madness? ${ }^{219}$ During the winter and spring months of 1865 , Sallie Putnam, who had long defended the extravagant needs of the elite for both personal and social reasons, even during war-time, also began critiquing what she called the "marked change visible in disrespect for money." Putnam disdained the “reckless expenditures and...extravagances, regardless of cost...balls, brilliant receptions of fashion and show and plenty." She desperately hoped that Richmond's partiers would soon realize the impropriety of their follies and regain the "moral courage" which Putnam felt was the Confederacy's strongest weapon against the Union's overwhelming numbers. ${ }^{220}$

Even entire sectors of the Richmond elite, including an enclave of the upper class who termed themselves the "Mosaics," quietly expressed their disdain for their class's obsession with elaborate, exclusive parties and material indulgence. Generally speaking, the Mosaics represented the more religious faction of elite society, as well as those individuals and their families who were far less politically connected and whose wealth stemmed from generations of work in reputable business ventures. Many of these individuals were Richmond natives; however, the Mosaics were also particularly attractive to middle-upper class refugees who did not come to the Confederate capital for political reasons, but who were merely seeking shelter, some means of government employment, and trustworthy company. Several Jewish families also assimilated into the Mosaics, which is not surprising, considering both the anti-Semitic bias of large sections of the capital elite and the general public in the nineteenth-century South, and the more welcoming and open-minded nature of the Mosaics as a whole.

219 McGuire, 328-9.

220 Putnam, 345. 
The Mosaics insisted that their own morale-boosting entertainments must not aim to appease such materialism, but instead must only seek to elevate the mind and cultivate one's intellect toward higher, pure, and more moral thoughts and behaviors. Described by T.C. DeLeon as "the quiet set to the giddier ones, and possibly the best...portion of Richmond society," the Mosaics shied away from "entertaining in the lavish old way" and instead embraced "quiet, homelike dinners, and quiet teas...in the later, trying days." Out of the Mosaics was born the Mosaic Club - the "legitimate progeny of abnormal conditions — just the clashing of bright minds in hospitable, cultured homes under the stimulus of rare good cheer and rare good coffee." The Mosaics included young amateur artists such as pianist Mattie Paul, Miss Evelyn Cabell, pianist Nanie Robinson, harpist Mrs. Clara Fitzgerald, Mrs. Thomas Semmes, the Macmurdo sisters, a local painter-singer from the outlying camps named Hector, Misses Dally and Lucy Grattan, and bassist James Grant—all of whom championed simple and intellectual entertainments over the flashy parties of their peers. ${ }^{221}$

A much more vocal critic of the ladies and a defender of pure female moralism, the aristocratic, South Carolina-born Phoebe Pember, who served as chief matron at Chimborazo (the largest military hospital on the continent), found the ladies" "extravagant" social behavior particularly abhorrent. A former hob-nobber with the Charleston elite prior to the war, Pember gave up all pretensions to privilege in the Fall of 1862, when she arrived at Richmond's Chimborazo hospital to offer her services as a matron. Dealing, day after day, with unimaginable sights of suffering and grief, Pember looked upon the active social world of the capital elite with great scorn, particularly in the latter part of the war. ${ }^{222}$ Pember wrote in her memoirs that during a time of war, "a woman must be hard and gross....must soar beyond

221 DeLeon, 201-210.

222 George C. Rable, introduction to A Southern Woman's Story by Phoebe Yates Pember (New York: G.W. Carleton \& Co., 1879; reprint, Columbia: University of South Carolina Press, 2002), xi. 
conventional modesty," and, in 1864, criticized Richmond's ladies for their decadent lifestyles and obsession with materiel. Pember felt strangely out of place amongst the women of her class, noting that "if Spartan austerity is to win our independence, we are a lost nation.",223

Pember was not alone in her chastisements of the capital elite that winter. Writing just three months before the end of the war, Richmonder Sallie Bird recorded with disgust her observances of the city sidewalks: "There has been and is considerable depression here and yet people have dances and weddings, and bands serenade (delightfully too) and ladies dress and walk the streets as if there was no war. Only the soldiers, the full hospitals and the wails of the bereaved tell us constantly of this dreadful war." ${ }^{224}$ Youthful artillerist and Richmond native, Colonel Willie Pegram also took aim at the ladies, bristling that the war had "weakened the civilians" and that "Richmond was getting fearfully corrupt." Pegram blamed the winter's gayeties and material indulgences upon the "parvenus and newcomers to the city," whose actions, Pegram feared, were "contaminating a great many formerly good people," contributing to the rapid decay of the city's moral fiber by late 1864, and thus posing a fearful threat to the city’s prized social order. ${ }^{225}$

Meanwhile, in February of 1865, Virginia Clay received a stern letter from a male friend with regards to her ever-active social life in which he told her that he had "withdrawn from society as it's at odds with my Christianity," and likewise encouraged Clay to "renounce this hollow, truthless world and ascent to that higher and nobler order of life for which your soul was created. Become a Christian yourself.,"226

\footnotetext{
223 Phoebe Pember, letter to Mrs. Gilmer, February 19, 1864, Southern Historical Society, University of North Carolina (Chapel Hill, NC).

224 Rable, 200.

225 Willie Pegram, letter to "Sister," February 11, 1864, Pegram-Johnson-McIntosh letters, Virginia Historical Society (Richmond, VA).

226 L. Lamar, letter to Virginia Clay, February, 11, 1865, David M. Rubenstein Rare Book \& Manuscript Library, Duke University (Durham, NC).
} 
As all of these criticisms reveal, establishing and maintaining one's place and social authority within the upper-most ranks of war-time Richmond society was a challenging, stressful, and often contested experience for the city's leading ladies. For women such as Phoebe Pember and Judith McGuire who ultimately forsook a spot within the capital elite in favor of dedicating nearly all of their physical and mental energies directly toward the war effort itself, the social stresses of daily life were somewhat relieved. However, they knew that they would never again carry the social and cultural clout that they had once enjoyed before the war. It is evident that some male and female peers understood that the ladies" "lavish" behaviors were not only necessary for the maintenance of their own sanity, morale, and ability effectively to lead society, but also were intended to serve the larger interests of society. However, due either to personal circumstance, particular experiences, or differences in gender and social position, many Richmonders simply did not share the ladies' philosophies and worldviews on society at war or their unique perceptions of social responsibility.

Many historians and contemporaries have often lambasted the actions of these women as self-indulgent, naïve, selfish and one-dimensional. However, a closer analysis of Richmond ladies' preoccupation with materiel and with exclusive social entertainments complicates such accusations by providing both critical insights into these women's perceptions of what was at stake, socially and politically, for them and for society, as well as a portal into their understanding of how best to maintain certain, critical elements of their identities as "ladies." In their minds, women such as Pember and McGuire, while still morally respectable ladies, had relinquished their titles as society ladies either willingly (in Pember's case) or out of the sheer inability (and desire) to "keep up" with their peers in comportment and in duty. Though they do not directly state it, the ladies most likely were confused by these women's diversions from the 
social and cultural prescriptions of ladyship, but they did not necessarily condemn or frown upon it. (Indeed, the summer after Pember began her tenure at Chimborazo, where she both worked and lived, a flurry of excited, though ultimately harmless, gossip erupted about why Pember insisted on spending every day and night surrounded by so many men and without a chaperone. However, Pember quickly put an end to such gossip merely by alternating her hospital stays with overnights at the houses of some respectable citizens). ${ }^{227}$ Some of Richmond's leading ladies even tried their own hand at hospital work during various parts of the war, and later wrote glowingly of the selfless women who had indeed given up a life of privilege and protection from the worst horrors of the war to help their sick and wounded defenders. ${ }^{228}$ It is difficult to say whether the city's leading ladies ultimately thought themselves socially superior to lady hospital workers, or whether they merely believed that for themselves, their rightful and most helpful place in society was as a social leader. Whatever their true opinions of their more nursinginclined peers may have been, most of the city's most prominent leading ladies forsook prolonged hospital work to focus the bulk of their efforts on rallying together the other leading ladies who shared their more traditional notions of southern ladyship.

Despite the ultimately controversial, and occasionally even harmful, nature of some of their actions, the leading ladies' conspicuous social behaviors and practices of perceived "indulgence" illuminate their perceptions of elite social privilege, necessity, and responsibilityperceptions that explain the reasons behind such behaviors. Although the ladies' perceptions of privilege and responsibility may not have always aligned with the social expectations of the poor and their critics, and although that mental disconnect may have contributed to some of society's dangerous disaffection with the ruling class, the ladies' execution of their professed

\footnotetext{
227 Fergurson, 226.

228 See, for example, Chesnut, 133; Cashin, 134; Rowland, 90-92, 113, 117; Davis, 203-4; Putnam, 40.
} 
responsibilities to society reveal how Richmond's female capital elite attempted to uphold multiple facets of the city's social order during the chaos of war. Through ritualistic defense of traditional social values, class hierarchies, and cultural practices, Richmond's leading ladies strove with all their might to restore stability and loyalty, morality and cheer, confidence and perseverance, and above all, order, both to their own class of ruling elites, and to their dangerously fragmented society as a whole. 


\section{Chapter 3-- Performing Ladyship, Sorting Society: The Promenade, Public Receptions, and Theater-Going}

In a March 12, 1864 edition of the Southern Punch, the editors remarked on the irony of an upcoming masked ball to be hosted by a Professor Bingham. Why should Richmonders need masked balls, they questioned, when in fact "we are all a mask?" Personal appearance and the carefully crafted projection of oneself before society appeared to be the standard preoccupation

of the day, they wrote. Instead, they cautioned, "we must endeavor to not appear, but to be."229

The editors' ruminations on Richmonders' preoccupation with how they appeared to others provide an illuminating insight into some of the most significant challenges to social order that the war continuously posed to the Confederate capital. With so many strangers flocking to the city, looking for jobs, shelter, personal betterment, as well as economic opportunity and social uplift, Richmonders lived in constant anxiety over which of these strangers they could trust, and which ones deserved their own upper niche within the highly prized and rigidly guarded social hierarchy. Throughout the early nineteenth century, but particularly during the war, strangers used a variety of social masks and deceptive self-projections to embed themselves within the most prized circles of city society and thereby reap the socio-economic benefits of such prowess. As a result, all Richmonders—but particularly the city's leading ladiesdesperately sought out a more reliable means through which to differentiate, both for themselves and for the general public, social "pretenders" from truly virtuous members of society.

As historian Karen Halttunen discovered during her research into nineteenth-century etiquette manuals, well-to-do ladies were well aware that the "exterior of life is but a

229 Southern Punch, March 12, 1864. 
masquerade" in which they themselves were expected to "dress ourselves in the finest fashions of society, use a language suited to the characters we assume, with smiling faces, mask aching hearts, address accents of kindness to our enemies and often those of coldness to our friends. The part, once assumed, must be acted out, no matter what expense of truth and feeling." 230 Thus, even after they had achieved a foothold amongst the capital elite, Richmond's ladies faced the daunting and continuous challenge of forcefully proclaiming and defending their claims to ladyship before the general public in order to help shore up the rapidly disintegrating borders between the social classes.

Part of this task included providing the public with a clearly delineated social hierarchy through the creation of both visual and physical boundaries within public spaces that segregated the depraved from the reputable. While the ladies attempted to impose this rigid social order upon their fragmenting society through demonstrations of force, authority, and exclusivity, they also hoped to attain what they realized was the necessary deference and loyalty of their inferiors to the traditionally rigid social structure of the Confederate capital. By engaging with their social inferiors - either directly or through merely amplified awareness of these social "others" - the ladies relied upon public rituals of social delineation to ascertain the needs and feelings of the lower classes, as well as the potential social threats posed by those individuals. Such interactions and observations allowed women to alter their own behavior accordingly in order both to gain the loyalty of their inferiors and simultaneously reassert their own social authority over them.

However, Richmond's leading ladies felt that such delineations of class and order were vital not only to the maintenance of their own social authority and privilege, but also were necessary for providing guidance for city dwellers as to which incoming individuals belonged to 
which class of society and how best to interact with — or stay away from — particular classes of newcomers in order to maintain standards of moral and respectable living. Additionally, the ladies used these delineative rituals to model the many important facets of respectability and, in doing so, try to transform particular public spaces and the social rituals occurring therein into educational and inspirational guideposts. These guideposts, they hoped, might teach and inspire members of the lower classes to elevate their own selves into more reputable and upright members of society, while simultaneously redirecting any straying members of the middling classes back to the straight and narrow. In order for their efforts to be successful, Richmond's leading ladies transformed their public appearances into carefully crafted rituals in which adherence to specific cultural codes for dress, social interaction, manners, and choice of venue played a critical role in the proper execution of their larger social goals.

Naturally, not every newcomer and individual whom Richmond's ladies encountered while out in public posed an imminent threat to society or was a person to be feared. Many of the individuals populating wartime Richmond's over-crowded streets were merely hard-working mothers, daughters, widows, elderly men, and children - both white and black — who were merely struggling to survive. As Richmond's leading ladies traversed the streets of the downtown area, they were greeted by hard-pressed women making their way to their new jobs at the Treasury and Quartermaster Departments, or by loud, but overall innocent, children whose ritual "rock battles" between the "Hill Cats" of Court End and the "Butcher Cats" of Shockoe Valley reflected the traditional mischief and playfulness of youth, and served as an important diversion from the war's miseries upon the city's adolescents. ${ }^{231}$ Soldiers and officers making their way to and from camp frequently greeted the ladies with doffs of the hat and a morning or

\footnotetext{
231 Thomas, 69; Michael B. Chesson, "Harlots or Heroines?: A New Look at the Richmond Bread Riot," The Virginia Magazine of History and Biography 92, no. 2 [April, 1984], 135.
} 
evening greeting, and elderly men, too old for the draft, stepped aside for the ladies to pass by them on the sidewalks as the men made their way to and from the Ballard or Exchange Hotels in search of news from the battlefront. The ladies saw the usual stream of slaves headed to work each morning, or running errands for their various masters in afternoons and evenings, and African American men and women milled about the entrances to the black churches every Sunday morning.

At the markets, in the stores, on the way to church, along the streets, and in the theater, Richmond's ladies navigated their way through crowds of upstanding, but poor individuals whose primary goal until the end of the war was merely the protection of home, health, and family. ${ }^{232}$ Ladies such as Judith McGuire occasionally noted her observations of such people in her diary. McGuire related one incident in which, while walking the streets, she came across a woman with a baby, weeping in an empty lot. McGuire and her companions were about to walk over to the woman to assist her when the woman's mother appeared and guided her away. "Poor thing!" McGuire lamented, "She is one of thousands....our people are suffering too much; they cannot stand it." 233

Even when the ladies frequently came in uncomfortably close contact with the city's growing number of prostitutes, "bedezined blacks," intoxicated individuals, gamblers, loafers, and other rag-tag looking persons, it was unlikely that their personal safety or integrity was in jeopardy. A significant number of these individuals had been forced into their situation by the unfortunate and tragic consequences of war, such as dislocation, the impressment or destruction of personal property, inflation and shortage, disease, injury and downright depression. Such

232 For more detail, see Thomas, Confederate State of Richmond, particularly 35-7, 105-198, and Fergurson, Ashes of Glory. 233 McGuire, 129; see also, Chesnut, 610-11. Chesnut, 500. McGuire, 252-5; Davis, Memoir, 329, 498. 
forces often compelled people into unenviable trades or both physical and mental states not of their own choosing, but rather out of sheer desperation or disaffection with the war. These individuals, too, populated the public streets, businesses, and social retreats of wartime Richmond, alongside their more well-off neighbors.

This examination of the individuals populating the Richmond streetscape is not to suggest that the elite were unnecessarily anxious over the sites they encountered along public thoroughfares and in public buildings. Real dangers—-both to self and to society—lurked amongst these crowds and caused understandable concern and anxiety. However, as has been true through history, the most vocal or dramatic of these individuals received the most press and public attention. In turn, the elite certainly did not view every stranger as a cause for immediate alarm. It is likely that they recognized in many of these passers-by the sheer desperation, tragedy, and unfair misfortune that had befallen many of these individuals as a result of the cruel tide of war.

However, for a society that was already on edge and already suspicious of large crowds of strangers, the wartime influx of so many strangers to the city-combined with the natural suspicions and fears that would infiltrate any society during a time of civil war-generated an overall wariness toward large, public congregations of strangers that only increased in scope and intensity as the wore dragged on. ${ }^{234}$ Thus, in their efforts to combat what they perceived as the rising threats to both the social order in the city and to their own social standing, Richmond's leading ladies exerted even greater efforts to adopt their own social "costumes" (as noted in chapter one), but desperately needed an appropriate public venue at which to showcase such

\footnotetext{
234 For more detail, see Thomas, Confederate State of Richmond, particularly 35-7, 105-198; see, for example, Putnam, 77,
} $211,255$. 
"costumes."

For many of Richmond's ladies, walking “the promenade," attending public receptions, and theater-going enabled them to gain that necessary, amplified awareness of their social inferiors and, essentially, helped the ladies "diagnose" the social problems and threats to Richmond society so that they better understood how to reinstitute moral and social order in the city. Additionally, such rituals granted them the vital opportunities to showcase their respectability, and thus right to privilege, while simultaneously enabling them to reinforcehowever silently - the valued tenets of moral living. Such tenets included tasteful dress and comportment, good manners, productive use of time and energy for (what they considered) the benefit of society, and the execution of social responsibilities by actively responding to the needs of society. By showcasing the materiel and behavior necessary to be a true "lady" in the Confederate capital during these three specific rituals, the leading ladies were able to reaffirm before the public — and thereby hopefully inspire the public toward - traditional standards of feminine grace, elegance, comportment, social responsibility, and moral respectability. Additionally, the ladies believed, their rituals within these three public forums allowed them to successfully differentiate themselves from the "pretenders" of society who threatened to unravel the social order through false appearances and claims to unearned respectability. Thus, by walking the promenade, attending public receptions, and showcasing themselves at various theater performances, the women of the capital elite strove both to reaffirm their own class privilege and engage with the lower and middling classes in silently brokering for a more orderly and upstanding society.

A long-standing tradition in antebellum Richmond, walking the promenade along East Franklin Street, around the Capitol Square grounds, and then back to Franklin by way of Broad 
Street was a special favorite of elite Richmonders' public activities. Ladies clad in the most upto-date fashions from Paris strolled slowly along the streets and Square grounds with their friends, chatting and gossiping underneath elegant lace parasols about the latest goings-on in the city. Young belles, bedecked in finery purchased from some of the most expensive dress shops in town walked circles excitedly around the Capitol building, hoping to catch a glimpse of some of the dashing young politicians making their way to and from work, and perhaps to receive a tip of the hat from one of these young gentlemen. Franklin Street boasted some of the most elegant mansions of the pre-war era, and the Capitol grounds were for the unspoken sole enjoyment of Richmond's most respectable white gentlemen and ladies. The sprawling magnolia trees and cool patches of shaded green grass beckoned to many of the city elite on the hottest of summer days. Altogether, Capitol Square served as both the playground and the resort grounds for the city's elite. $^{235}$

During the early days of war, military parades and drills supplanted the peace and tranquility of the Square. Patriotic men and women from a cross section of classes gathered to cheer on their husbands, sons, brothers, and fathers in uniform and rally around the Confederate cause. However, as the heart of the military festivities spread to the numerous camps on the outskirts of the cities, the elite once again laid claim to the pastoral lawns and paths encircling the Confederate Capitol... or at least they tried to do so.

Less than one year into the war, Richmonders began to notice a change in the character of their favorite public retreat. Loafers, loungers, lowly "foreigners" (refugees and immigrants), prostitutes, drunks, and other street "urchins" started infiltrating the sacred grounds, clogging

235 Thomas, 16, 24-25; Kimball, 4. 
walkways, plying their trades, and otherwise tainting the refined beauty of the Square. ${ }^{236}$ Although the Square grounds had always been regarded as a cherished place for much needed social retreat and relaxation, the civically enforced, high public standards of dress, decorum, and upstanding behavior therein often had successfully prevented lower class individuals from lingering within the confines of the Square.

By July of 1862, the Richmond Daily Examiner was printing numerous articles expressing the anger of upper-class residents over the number of "idlers and sleepers" in what had been a "place of healthful recreation and promenade." The paper pleaded for more stringency in the laws to keep such idlers_-including common soldiers_ out of the square. ${ }^{237}$ In October of that year, the Examiner angrily reported another, even more shocking offense to the promenaders. According to the paper, a group of well-to-do Richmonders who were walking near the corner of $9^{\text {th }}$ Street and Broad Street, directly along the promenade route, recently had watched in horror as a carriage arrived at the door of the local Passport Office "with three painted and bedezined prostitutes," along with a "dandy puppy disgracing his uniform and receiving the looks and caresses of the abandoned creatures---the arm of one around his neck!" "So glaring and unblushing was the scene in its indecency that it arrested public attention," the Examiner claimed. The shocked and insulted witnesses to the scene were "determined to expose it" and took down the number of the hack that the offenders were traveling in and reported it to the Mayor. The Examiner irately concluded with hopes that "we will be able to walk the streets of Richmond without such insult in the future" and that the Richmonders would "do anything" to

\footnotetext{
236 Richmond Examiner, April 6, 1863, June 4, 1863, February 27, 1863, April 6, 1863.

237 Richmond Examiner, July 14, 1862, July 15, 1862.
} 
end such licentious and indecent public behavior. ${ }^{238}$

By the third year of the war, such shocking and improper scenes appeared to be endemic in the now fearfully corrupt city. In January of 1863, the Richmond Daily Whig repeated its early-war demands for a new House of Correction to deal with the growing number of troublemaking idlers and vagrants cluttering the streets. The article focused specifically on the case of one young girl named Ellen Martin. Martin was brought before the Mayor for vagrancy and for begging in the streets. The paper declared that she was "notorious for depravity and mostly hangs out at hotels but also public spaces annoying whoever she likes with her obscenities." The city police ultimately arrested Martin, who was placed in jail "where her morals can improve without association with the other inmates." The paper stressed that, in order to purify the city streets and restore to the respectable classes their public thoroughfares, the city desperately needed some sort of workhouse for juvenile correction for its young female offenders, and blamed the city government for giving up its brand new Alms House to the Confederate Medical Department for its use as a military hospital. ${ }^{239}$

It is interesting to note that, while most papers acknowledged that these idlers and unsavory characters were the byproduct of the South itself, other newspapers preferred to cast the blame for the prevalence of such ne'er-do-wells not upon the influx of southern refugees to the city, but on the tide of supposed "Yankees" and "abandoned Libertines from Washington and Baltimore" that were spilling into the city and corrupting society. ${ }^{240}$ In September of 1861 , the Richmond Daily Examiner bitterly reported that "Washington and other cities have vomited

238 Richmond Examiner, October 24, 1862.

${ }^{239}$ Richmond Whig, January 1, 1863; Richmond Enquirer, January 1, 1863, June 24, 1863.

240 Richmond Examiner, December 23, 1862. 
forth" men and women of the worst character who threatened the reputation of the city. ${ }^{241}$ Meanwhile, the Richmond Enquirer claimed that a large contingent of Yankees was degrading the formerly polished society of Virginia's capital city. These Yankees, many Richmonders suspected, were either trapped in the Old Dominion once Virginia seceded or worked as traitors and spies for the Union, leaching off of the city's supplies while gathering critical information for northern politicians and generals.

Wherever these newcomers had arrived from, by all accounts their presence in the Confederate capital deeply unsettled and offended the sensibilities of the city's leaders. In February of 1864, the Enquirer bristled that "the old time society of Richmond is changing." According to the paper's editors, "hideous" elements of northern society, such as public crudeness, social coarseness, and immoral "strumpetocracy" were replacing the former virtue and grace of Virginia's capital city. The editors feared that, even while the South was engaged in a bloody war against the North and its "debased" society, elements of that society were creeping into the Confederate capital, winning over some of Richmond's previously upstanding citizens, and undermining the overall fight for southern independence. ${ }^{242}$

To make matters even worse for the respectable ladies of Richmond, the world's "oldest profession" flourished in Richmond during the war. ${ }^{243}$ The city had dealt with its share of prostitution before the war, particularly in the three red-light districts of "Solitude," a section of Cary Street running between $6^{\text {th }}$ and $8^{\text {th }}$ Streets, "Sugar Bottom," a notorious hollow along the base of Church Hill on the eastern outskirts of the city, and "Pink Alley," an unspecified den of

241 Richmond Examiner, September 4, 1861.

242 Richmond Enquirer, February 12, 1864.

243 Fergurson, 100. 
immorality and vice. ${ }^{244}$ In some of these areas, such as Solitude, where "vice and forsaken creatures - the lowest of the low" roamed the streets and where "brothels, thieving dens, garroters, and whiskey inlets will rob you of purse and life...where lewd women, crackmen, and skinners [gather]....and "all through the night the sound of the wretched violin play[s],"...there were so many murders and robberies that "even the night watchmen turn[ed] away" from the areas. $^{245}$

However, much to the horror of the city's more upstanding residents, during the war, the number of brothels and "disorderly houses of ill fame" exploded as Richmond's many impoverished women entered into the sex trade in order to support themselves and their children, and other enterprising women of some means sought to reap the benefits of new, war-born markets. Unlike the prewar houses of prostitution, these new "dens" and brothels stood in plain sight of the public, with numerous clusters of such houses bordering the Capitol Square grounds, the old city market, the elite residential areas bordering Franklin and Grace Street, and near the popular commercial districts on the eastern fringes of Cary Street. In addition to daily "balls," parties, and rowdy late-night business, these houses of ill repute attracted the lowest sort of men and women who often drank and gambled the night away on the first floor of the brothels and later spilled out into the city streets in fits of violence that frequently resulted in stabbings, shootings, and murders. ${ }^{246}$

But most offensively, the depraved women working in such houses occasionally displayed themselves within the front windows of their establishments in "various states of

\footnotetext{
244 Thomas C. Lowry, M.D., Sexual Misbehavior in the Civil War: A Compendium (Xlibris Corp., 2006), 25.

245 Richmond Examiner, December 6, 1861.

246 Lowry, 25-35; Richmond Examiner, June 25, 1862, July 30, 1862; August 10, 1863, April 19, 1862, May 14, 1862, September 3, 1863; Richmond Whig, March 28, 1864, April 14, 1864, August 16, 1864; Richmond Daily Dispatch, October 14, 1861, March 21, 1862, December 29, 1862, July 1, 1864, December 28, 1864.
} 
undress and suggestive poses," winking, "hallooing," even spitting upon passers-by and generally "making the night hideous with their maudlin reverie." Two such brothels existed in alleys immediately bordering the Square, with one conveniently established directly across from a soldiers' convalescing retreat at the local YMCA, and the other just two blocks down from one of the main entrances to the Square. ${ }^{247}$ Many of these less-than-ladies also disported themselves along the Capitol Square grounds in their cheap finery, shocking the morals of the pious elite and crowding the sidewalks that formerly were the sole purview of the Richmond's most respectable ladies. In an August 22, 1864, edition of the Enquirer, Mayor Mayo bemoaned the depraved state of Capitol Square: "Never was a place more changed than Richmond. Go on the Capitol Square any afternoon and you may see the women promenading up and down the shady walks jostling respectable ladies in the gutter....or leaning upon the arms of officers."248

The prostitutes also laid claim to many of the city hacks and carriages in which they accompanied their clientele through the city thoroughfares, en route to and from their various places of "business." The Richmond Daily Dispatch repeatedly complained about the shortage of cabs on the square, most of which were "on permanent hire" to the courtesans of the city. ${ }^{249}$ One angry reader wrote into the Richmond Daily Enquirer that such "harlots should be horsewhipped," while the Dispatch bemoaned that "they have been disporting themselves extensively on the sidewalks, and in hacks and open carriages [with] smirks and smiles and winks....and remarks not of a choice kind in a loud voice."250

Additionally, the Mayor's Court teemed with scores of Richmond's soiled doves who all too often drank themselves into a stupor and were either found lying, unconscious, on the

\footnotetext{
247 Richmond Daily Dispatch, May 6, 1862; Richmond Sentinel, July 1, 1864.

248 Wiley, 162.

249 For example, see, Richmond Daily Dispatch, May 13, 1862.

250 Lowry, The Stories the Soldiers Wouldn't Tell, 71.
} 
sidewalks, or engaging in both verbal and physical assaults upon their peers and even upon upper-class bystanders. ${ }^{251}$ Mayor Mayo himself was enraged that decent white civilians making their way to church could not get to their place of worship without being assaulted by the kisses and flirtations of renowned Richmond prostitutes, such as Clara Coleman, who frequently paraded through the city and flirted with military officers from her carriage drawn by yellow horses. $^{252}$

The continuous arrival of refugees and the increasing number of the city poor unquestionably forced some of these members of the "lowly sort" to overflow into the promenading grounds in and around Capitol Square and along the city's prime thoroughfares. By October of 1863, the Southern Punch reported that,

This pent-up Utica of ours is over-crowded. Refugees from every section of the CSA have come hither in search of safety and something to do. Every railway train bears a living freight of visitors to Richmond, on transient business. Every article of wearing apparel, every mouthful of food, every Calcutta Black Hole of a room, every cart-load of fuel, commands fabulously high prices. Where this diabolism will stop, no one can tell.

The periodical lamented the forlorn look of the city, noting, "It is not easy to draw in advance a picture of distress which would appall thousands, could they see its tearful reality. But thin garments, damp, freezing rooms, poor and scant diet---and often none at all—may convey a taint idea of what is inevitable in Richmond during the coming winter."253

The increasingly dire economic conditions in wartime Richmond forced many women into the business of prostitution to support themselves, and in many cases, their young children. Clothed in mock silks, wigs, and jewels that all too often resembled the dress of the female elite, these women were forced to exaggerate, if not outright lie about their true class and identity in

251 Richmond Examiner, June 20, 1861, June 25, 1861, July 12, 1861, August 19, 1862; Richmond Whig, April 14, 1864. 252 Fergurson, 100.

253 Southern Punch, October 10, 1863. 
order to gain access to places and people with whom they could do a profitable business in order to survive within the new whirlwind of society. In September, 1863, the Punch confirmed that "lying is the order of the day and truth the most unfashionable of all things. A man [or woman] who pretends at these times...to adhere to the truth, would at once be considered a fool or partially insane and be ruled out of the speculating fraternity." Although such trends deeply unsettled the editors, they responded with remarkable pragmatism, if not empathy for struggling individuals such as the city's prostitutes, stating "there has been a fall from truth among the native people... and it seems like everybody has turned hypocritical out of dire necessity...it has become necessary to lie, they are compelled to do it in self-defense" or else their "lying neighbors would strip them of everything or be left so behind in business that they couldn't catch up." Unlike the anxious members of the capital elite, and more in line with many members of the middling and lower classes, the Punch appears to have understood, though it never morally condoned, the deceptive tendencies of the city's social pretenders. The November 7, 1863 editorial concluded that "the truth is good in small samples but not in the extreme," as being truthful about one's social status or class was considered "simple and foolish" and put individuals in danger of socio-economic suicide. ${ }^{254}$

Despite — and indeed, perhaps in light — of the distasteful and threatening social displays of the "soiled doves" within and adjacent to the Capitol Square promenade, Richmond's ladies promenaded on. Interestingly, however, while the male population raged against the aforementioned indecencies occurring along the public thoroughfares and demanded greater regulation of such actions, the ladies of the capital elite were largely silent on such matters. The ladies' memoirs and letters mention their daily walks and promenades, but only briefly, and without much mention or concern over the social degenerates they encountered along their

\footnotetext{
254 Southern Punch, November 7, 1863.
} 
way. $^{255}$ Therefore, our knowledge of the ladies' participation in the promenade stems primarily from newspaper descriptions of the ritual.

With such a large silence in the ladies' own writings about their reactions to the lowly women they certainly encountered out on the streets, one can only speculate as to why the women continued their promenades. It is possible that the ladies merely felt that it was their right to continue their pre-war practices of exercise and social interactions, regardless of who else might be walking around them. Richmond's ladies most likely relished the chance to showcase their elegance and privilege before an even larger audience. For a lady who craved the social spotlight, what was there not to relish about this opportunity?

However, when juxtaposed with the aforementioned rituals of continuous, carefully crafted rituals of social display during house visits and exclusive parties, the ritual of the promenade appears to be a highly public extension of these other executions of elite women's social agendas. With its carefully planned route, prescriptions for dress and comportment, and its roots lying in the rich, antebellum traditions of social display and delineation, the promenading ritual enabled women not only to showcase their own social authority before the public, but also to conspicuously differentiate, for the clarity and edification of the public, their truly respectable ladyship from the mock ladyship, lasciviousness, phony virtue, and cheap finery of Richmond's depraved and "painted" women. In exposing the vice and vulgarity of the unenviable class of pretenders, the ladies hoped to root out, once and for all, what the Southern Punch called the "moral delinquents" of society. ${ }^{256}$ Therefore, the ladies' attempts at reclamation of a prized public space not only was an attempt to erect physical barriers between

\footnotetext{
255 Chesnut, 512, 449; Harrison, 187; McGuire, 301-304; Putnam, 315-317.

256 Richmond Daily Dispatch, October 15, 1863; Richmond Enquirer, June 4, 1863; Southern Punch, September 19, 1863.
} 
the capital city's classes but also served as a distinct, visual representation of the social hierarchy and order that the ladies hoped to impose upon society.

Additionally, as was discussed in the previous two chapters, the ladies were constantly aware of, and took pride in the fact that the public gaze followed their every appearance and behavior. Furthermore, they were well aware that part of their role as moral and social guardians of the city included the edification and inspiration of the public toward more personal uplift and orderly behavior that would support, rather than undermine, the Confederate war effort at home. Therefore, it is likely that the ladies viewed their forceful displays of refinement and respectability as inspirational models for the lowly sort of women who congregated around Capitol Square and whose vice and deviant behavior posed continuous threats to the moral order of society.

Why the ladies did not write in more detail about their promenades and the individuals whom they encountered along the way is somewhat of a mystery. It is likely that, in both Richmond and in other prominent southern cities, the promenade had been such an intrinsic aspect of elite life — as both privilege and responsibility — since childhood that Richmond's leading ladies may not have always consciously reflected on why they continued the tradition during the war. That does not necessarily mean that this practice had lost its meaning or social intent, but rather that it had become absorbed into the cultural milieu in which the ladies operated long before the war. Therefore, the ladies' maintenance of this ritual, even in the face of such shockingly inappropriate scenes as the ones described earlier, may simply have stemmed from a pre-war familiarity with the need to perpetuate such cherished rituals, especially when challenged from below. Ultimately, while the ladies' conscious adherence to the ritual's prescriptions of dress and the regularity in which the promenade was performed signifies a 
conscious awareness of the importance of this vital ritual, they may not have felt (or thought of) the need to reflect on such a natural part of their previously established daily routines and social displays.

It is likely that the increase in social threats from the prostitutes and other depraved individuals in and around Capitol Square strengthened the resolve of Richmond's leading ladies to preserve the ritual of the promenade, however subconscious that resolve may have been. It is also particularly likely that part of the reason for the ladies' persistent participation in the promenade during the late war period lay in their desire to reclaim the Square neighborhood from, and thereby confirm their authority over, Richmond's expanding African-American population—a group of "promenaders" about whom the ladies did write concernedly. (Perhaps the fear of, and desire to oust the offending blacks from the Square grounds trumped the ladies' outrage over the intruding white prostitutes, which might also potentially explain some of ladies' silence about the prostitutes).

As the number of war-related, "for-hire" jobs for slaves increased between 1861 and 1864 , and as certain sectors of the free black population took advantage of wartime economic opportunities, more and more African Americans had access to funds with which they could outfit themselves in decent clothing and even some fine accessories, such as bonnets, canes, top hats, and silk shawls. ${ }^{257}$ Many of these African Americans had moved to the city specifically to take up jobs in Richmond's wool, flour, iron, and munitions factories whose products were essential to keeping large portions of the Confederate army and navy armed and fed throughout the war. Other, free African Americans expanded their pre-war businesses as blacksmiths, tailors, cobblers, barbers, saddle-makers, laundresses, cooks, and seamstresses to reap the

257 Richmond Whig, April 14, 1864; Kimball, 28; Carey H. Latimore, IV, “Always a Minority: Richmond Area Free Blacks in the Civil War Era," (Ph.D. diss., Emory University, 2005), 95-6, 99, 166; Midori Takagi, Rearing Wolves to Our Destruction: Slavery in Richmond, Virginia, 1782-1865 (Charlottesville: University Press of Virginia, 1999), 2. 
benefits the exploding urban population that was always in search of new goods and services. Still others flocked to the city's many hospitals for employment within the nursing staff, or sold foodstuffs grown on their small farm plots outside the city in Richmond's markets for impressive sums. While blacks saw certain freedoms, such as the ability to gather in large crowds for social purposes curtailed during the war, and although whites placed heightened restrictions on the movement of blacks in and out of the city during the war years, many slaves and free blacks found creative ways to carve out a niche for themselves in the market and thereby acquire some personal spending money. ${ }^{258}$

Already incensed and concerned by the rise in assaults, theft, and arson within the black community, the "uppityness" and "negro aristocracy" of the city's black population proved simply too much for Richmonders to stomach. ${ }^{259}$ On January 2, 1863, the Richmond Daily Examiner reported one particularly outrageous affront to a crowd of white Richmonders. On a recent evening, a congregation of white churchgoers at the Broad Street Methodist Church were barred from exiting the church due to the arrival of a "negro wedding cortege" at the doors whose members arrived in all sorts of fancy attire. To the white churchgoers' horror, the fancy black wedding party appeared to feel quite entitled to the church space, "forcing the congregation to retreat through them promiscuously." Some of the congregation noted that two lowly stable workers were amongst the wedding party, and indignantly commented that it appeared that Richmond's black population intended to "usurp the church" altogether, while simultaneously making a mockery of respectable white people and their style of dress. ${ }^{260}$ To make matters worse, the Examiner noted in October of that year that such uppity blacks seemed

\footnotetext{
${ }^{258}$ Latimore, 93-104, 107-108, 119.

${ }^{259}$ Richmond Whig, June 13, 1864; Harrison, 134; Putnam, 264, 266; Kimball, 28; Richmond Examiner, October 6, 1863; March 5, 1864, September 29, 1864, July 15, 1862; Latimore, 143, 172; Takagi, 2, 101, 102, 122, 137, 139; see also, Genovese, 97-112.

260 Richmond Examiner, January 2, 1863.
} 
to be omnipresent, that "many able bodied negroes... were now in the streets," riding in hacks and packing the third tier of the Richmond Theatre, and that "ogling negro wenches" degraded the street corners of the downtown area. ${ }^{261}$

Prior to the war, resentment and concern over the growing threats from the black population had already resulted in the 1857 Ordinance Concerning Negroes, which had banned African Americans from riding in carriages, frequenting public grounds or graveyards, or assembling in groups of five or more. The Ordinance had also prohibited public smoking, swearing, carrying canes, and purchasing weapons and alcohol. In other words, the Ordinance had prohibited blacks from disporting any finery, while simultaneously strengthening vagrancy laws that largely prohibited blacks from strolling or "idling" along the city streets to no purpose. ${ }^{262}$ Both the Richmond police and the martial guards tried to enforce the 1857 Ordnance with even greater authority during the war; however, even their increased public presence did not stop the black population from engaging in illegal activities. ${ }^{263}$ That black Richmonders dared to flout these rules that white Richmonders deemed necessary for a safe and civil society greatly unsettled and disgusted the white community, and particularly members of the upper class.

An August, 1864 issue of the Southern Punch reveals that, even during the late war period, African Americans still flocked to the city's public thoroughfares, many of whom sported fine dresses, hats, shoes, and jewelry. "It would be difficult to find a more worthless, insolent, bedezzined and becaned set of negroes than on our thoroughfares Sunday,” the Punch fumed. "They swarm like black bees loosed from their hives and are insufferably insolent." Worse yet, white women found it nearly impossible to squeeze past these "brazen" blacks on the narrow city sidewalks without being forced to make physical contact with them. "[The negroes] never yield

261 Richmoner Examiner, October 24, 1863, September 4, 1862.

262 Kimball, 27; Latimore, 138; Takagi, 135.

263 Richmond Whig, January 1, 1863. 
the parvenu to whites," the Punch stated, indignantly. Even the most "poorly dressed white woman has to turn aside or stop while they blockade common passage. ${ }^{264}$ Surveying the city streets, the Punch observed a strange mix of individuals clogging the thruways. The editors reported seeing "weary Confederate soldiers, a fancy clad negro with a cane, [and] a pale, hungry looking white woman in faded calico frock [living off of] meager rations." And yet, despite this sad scene of white female suffering they also saw, much to their shock and disgust, a "negro wench dressed most comfortable and neatly in gingham, silk, gloves and a parasol, and fashionable boots...negroes reading the morning paper to demonstrate their worthlessness and insolence." Completely repulsed by such scenes, the editors forcefully stated that Richmond must "curb such insolence. ${ }^{265}$

Mary Chesnut also commented on the indecency of these displays of fashion by the black population, writing that bedezined blacks would frequently congregate for "negro balls" in the city where raucous dancing, feasting, drinking, and fighting frequently drew the attention of the night watchmen. ${ }^{266}$ Although the city ordinances restricted gatherings of more than five blacks at any given location and required both slaves and free blacks always to carry passes from their masters or freedom papers, such gatherings continued anyway throughout the war. ${ }^{267}$ During the later part of the war, she also expressed her sadness over the fact that, she, like many other wealthy women, was forced to sell her own dresses to a mulatto woman, of all people, in order to buy food and other necessary supplies that were now priced at an exorbitant rate. Chesnut criticized the filth and disorder of the dress shop and lamented that respectable white women

264 Southern Punch, August 29, 1864.

265 Southern Punch, August 29, 1864.

266 Chesnut, 458; Richmond Examiner, December 16, 1862; See also, Takagi, 101-102.

267 Kimball, 28; Takagi, 137. 
were being forced (or expected) to sell their finery to colored shopkeepers while lowly negroes casually shopped around them for Parisian silks and satins. ${ }^{268}$

Even Sallie Putnam complained that well-to-do ladies were being forced to shop "amongst the low and depraved" negroes whose thirst for finery, by the late war, seemed unquenchable. Putnam angrily wrote of the numerous "pilfered wardrobes and thefts" which were undoubtedly up, "especially among the domestics." Fashionable ladies who attended early prayer meetings along Franklin Street or who left their houses to visit friends for tea or dinner would often return to find some of their nicest dresses, bed clothes, trunks and jewelry stolen by personal maidservants or other female domestics. ${ }^{269}$

In the minds of Richmond's ladies, with all of these female slaves and free blacks roaming the streets, promenading through public thoroughfares, carriage riding through town, and promiscuously parading into churches, shops, and other public venues, they had just cause to be concerned. ${ }^{270}$ Though they do not directly state it, these women's diaries and memoirs imply the prevalence of a great social angst and fear that the privilege of white women of all classesbut especially those of the most elite — was being threatened and eroded by colored women. Fears of black rebellion and violence while their men were away at or preoccupied by war haunted white women all over the South. The ladies of Richmond were no exception. In their minds, a black individuals" donning and flaunting of a piece of "white" finery was a threatening social statement and a dangerous first step down the path toward complete rebellion. Therefore, threats from lowly white women were certainly a concern, but threats both to class and racial privilege, as well as order, were both too vile and treacherous to ignore.

268 Chesnut, 588.

269 Putnam, 264-5.

270 Takagi, 136, 139. 
Though we may never know for sure, it seems quite likely that Richmond ladies' continuation of the promenade was a forceful, though still normal, reaction to threats from below and from the "inferior" race. Displeased, but undeterred by the sights that greeted them during their public outings, Richmond's women strolled and rode on until the very end of the war. Indeed, Richmond's leading ladies were so dedicated to the ritual of the promenade that women such as flirtatious young belle, Sallie "Buck" Preston, a prominent member of Mary Chesnut's "court," even risked her health to go pleasure riding through the city's main streets one December day in 1863. Despite having just suffered a cold, Buck and Mary went out for a long carriage ride dressed in their finest, Buck adorned in black velvet and ermine, "looking queenly...wrapped in furs and rugs" and sure to catch the attention of bystanders on the city's most popular thoroughfares. ${ }^{271}$

The ladies even continued their ostentatious strolls and carriage rides along the Squaregrounds in the face of their ever-vocal critics from the Southern Punch. During November of 1863, the Punch scorned the "muffs, cloaks, overcoats, shawls and blankets" that warmed the shoulders of the elite walkers, who, with their "faces buried deep in their high collars and comforters....hurr[ied] home to smiling faces....and with bounteous boards and hearthstones" to be "warmed by grates brimful of red hot coals," while "[t]here were many, very many in Richmond who have no overcoats, cloaks, shawls or blankets and the old threadbare garments that barely cover their nakedness are but poor protection against rude winter's blast." The Punch begged the seemingly carefree promenaders for some aid for the poor, but feared that this class of Richmonders had long since forgotten virtues such as empathy and charity. "Wealthy citizens of Richmond," the Punch begged, "Punch appeals to you. You have acted a noble part towards

\footnotetext{
271 Chesnut, 509.
} 
the soldiers in the field, let not their mothers, wives and children perish with cold and hunger at your very doors!"272

In addition to the promenade, public receptions held ritually at the Presidential mansion on $12^{\text {th }}$ and Clay Streets and at the Governor's Mansion on Capitol Square provided vital opportunities for social display and for the leading ladies to engage their social inferiors in symbolic negotiations over power, civic responsibility, and societal order. ${ }^{273}$ Often attracting a wide range of attendees from diverse social classes, ${ }^{274}$ such levees were, in the words of social commentator T.C. DeLeon,"social jambalaya, but [they were] also novelty...these levees had their uses as an amalgamating medium, a social 'Change whereon the provincial bear met the city bull, nor found him deadly of horn." ${ }^{275}$ Young, well-to-do Kate Rowland noted that these receptions were "quite a brilliant assembly." While listening to the military band serenade the guests with "some beautiful airs," Rowland and her friends "promenaded through the long rooms," simultaneously sporting their own finery before fellow guests, while standing in awe of the of the powerful, historical celebrities, past, present, and future who "might tread these [same] fine carpets."276 Public receptions occurred each New Year's Day, from 1862 to 1865, but the President and First Lady also occasionally surprised the city with additional receptions when they had the time and materials to do so.

As the official hostess of the receptions, Varina Davis was praised by peers and the press alike for serving as both "politician and diplomatist in one" to friends and strangers, with her

\footnotetext{
272 Southern Punch, November 7, 1863.

273 Richmond Daily Dispatch, January 2, 1862; Richmond Examiner, January 2, 1863, January 2, 1862, January 2, 1864.

274 Cashin, 143; Richmond Daily Dispatch, January 2, 1862; Richmond Examiner, January 2, 1863, January 2, 1862, January 2, 1864; Harrison, 127.

275 DeLeon, 67; Cashin, 122; see also, Kate Pleasants Minor, “Richmond in the Sixties,” box 2, Southern Women's Collection, Eleanor S. Brockenbrough Library, Museum of the Confederacy (Richmond, VA), 8.

276 Kate Rowland diary, entry for February 26, 1865, Kate Rowland Papers, Civilian and Home Front Collection, Eleanor S. Brockenbrough Library, Museum of the Confederacy (Richmond, VA), 146.
} 
fellow elite "sisters" following her lead. ${ }^{277}$ Understanding that, "in capitals, it takes all sorts of people to make a world," these ladies welcomed both the most distinguished statesmen and diplomats and the city's impoverished women into the inner sanctum of the Davis home in a display of authoritarian patronage. ${ }^{278}$ As discussed previously, the Davis home much more frequently served as the center of lavish, exclusive state dinners, theatricals, luncheons, and other gatherings for the city's female elite, which made the public's invitation to the mansion even more extraordinary. ${ }^{279}$ T.C. DeLeon, Mary Chesnut, and the Richmond press lauded the public receptions as, what DeLeon called, the "most remarkable aggregation of distinction and commonplace" and praised Varina Davis in particular for her remarkable talent for "melt[ing] the social forest about her" at the receptions. Not only did the gatherings "prove attractive to distinguished visitors," DeLeon and Chesnut boasted, but even more importantly, they were also "useful in letting the President and his wife devote more attention to the plainer people." With military bands serenading the guests with popular and classical music, Congressmen, bureaucrats, Generals, young recruits, refugees, and foreigners mingled together for three full hours in "more variety than the East Room" of the Washington White House. In bringing people together who had never before met, and in "never differentiating" between guests of all classes but rather making all "feel present by right," the First Lady brilliantly performed her role as

277 DeLeon, 67; see also, Chesnut, 541, 545; McGuire, 96; Richmond Examiner, January 2, 1862, January 2, 1864; January 16, 1864, January 20, 1864, January 21, 1864, January 23, 1864; Richmond Daily Dispatch, December 31, 1861, January 2, 1862.

278 Chesnut, 541, 545; McGuire, 96; Richmond Examiner, January 2, 1862, January 2, 1864; January 16, 1864, January 20, 1864, January 21, 1864, January 23, 1864; Richmond Daily Dispatch, December 31, 1861, January 2, 1862; 279 DeLeon, 99; see also, Chesnut, 541, 545; McGuire, 96; Richmond Examiner, January 2, 1862, January 2, 1864; January 16, 1864, January 20, 1864, January 21, 1864, January 23, 1864; Richmond Daily Dispatch, December 31, 1861, January 2, 1862. 
hostess, caretaker, and First Lady of the Confederacy and earned the respect of Richmonders of all social backgrounds. ${ }^{280}$

By hosting routine public receptions, Varina Davis sought to promote social harmony in the capital city by providing a forum in which a cross-section of Richmond society could gather to negotiate, however silently, with each other for their respective interests, privileges, and protection. These highly publicized and patriotic gatherings temporarily broke down the physical barriers between the classes and served simultaneously as a way for all classes to rally together around a central political cause, hopefully with "every heart beating in unison," according to Judith McGuire. However, the formality of such events simultaneously ensured that the social boundaries between the upper and lower classes still endured. ${ }^{281}$

As both political and social diplomatist, Varina's invitation of the general public to a high profile event at the Presidential Mansion that was co-hosted by her fellow leading ladies and gentlemen of the Capital served as a conspicuous display of patronage, yet power over the poor and the potentially "threatening" lower members of society. Dressed in their impressive finery, and conspicuously enjoying the fine company and camaraderie of their fellow elites, Richmond's leading ladies presented a powerful picture of social distinction and authority that would not have been lost on the lower and middling classes, even those whose best efforts at dressing and behaving respectably would always pale in comparison to their superiors. In fact, the receptions were so lavish that the First Lady and her peers often were forced to "tone down" the flash of the receptions by critics who accused them of being too "hoi polloi" for common society. ${ }^{282}$

\footnotetext{
280 DeLeon, 196-7; Wiley, 106; Cashin, 143; Chesnut, 541, 545; McGuire, 96; Richmond Examiner, January 2, 1862, January 2, 1864; January 16, 1864, January 20, 1864, January 21, 1864, January 23, 1864; Richmond Daily Dispatch, December 31, 1861, January 2, 1862.

281 McGuire, 96; Richmond Examiner, January 2, 1862, January 2, 1864; January 16, 1864, January 20, 1864, January 21, 1864, January 23, 1864; Richmond Daily Dispatch, December 31, 1861, January 2, 1862 282 Wiley, 110.
} 
In turn, by receiving and accepting an invitation to one of the receptions, these "lesser" guests were expected to subscribe to a certain set of manners and behaviors that emphasized a social deference to their hosts and hostesses. Such practices stemmed from a core set of lateeighteenth century culture and customs of Virginia to which nineteenth-century Richmonders still proudly adhered. ${ }^{283}$ Heavily rooted in a culture that stressed the importance of authority over, but also the benevolent "protection" of, social inferiors (in general, slaves, women, and the lower classes), Richmonders felt both a responsibility and a pressing need to reaffirm the traditional power dynamics of their relationship with the general public at major events such as these receptions.

However, the receptions served as equally important venues where the poor could express their personal concerns and needs — both verbally and through their mere appearance - to the leading men and women of the Confederate capital. The regular availability of the First Lady, Richmond's leading politicians and generals, and other influential men and women of the capital elite at the receptions enabled the poor to discuss personal, family needs with the wealthy attendees who were expected, in turn, to provide some form of possible assistance to those in need. Frequently, even if the poor were not able to engage in a direct discussion with one of Richmond's leading ladies, their rag-tag, faded, and tattered outfits (especially toward the end of the war) silently, but still powerfully, conveyed the plight and needs of the poor to Richmond's ladies. This tacit plea for help likewise reminded the elite of their contractual duties to their social "charges," while highlighting the ways in which the ladies needed to alter their own engagement with the poor in order to assure their deference to elite rule.

As a whole, the Presidential receptions could potentially benefit both the leading ladies and the poor. The ladies knew that in order to maintain the necessary allegiance of the middling 
and lower classes, they had to combine their displays of authority with demonstrations of care and protection for their social inferiors. ${ }^{284}$ The ladies hoped that, by lending an ear or by at least appearing sympathetic to the needs of those less fortunate than they, the ladies might re-cultivate the respect and loyalty of their social charges, as well as the general public's adherence to the social and moral dictates of the ruling elite.

Additionally, the receptions provided the ladies with the chance to "case" a cross section of society within the comfort of their familiar surroundings in order to determine the overarching needs of the general public. The ladies' fulfillment of those needs, often through charity and other acts of benevolence, might help to stabilize the social order and either prevent or eradicate already existing immoral and rowdy acts of desperation and anger. The receptions also conveniently provided the capital elite with a frequent finger on the ever-fluctuating pulse of the Richmond community. By allowing any and all city-dwellers to attend the receptions, the elite were able to survey the attendees for potential threats to the precarious social order of the city. Such observations could provide additional, valuable insight into how the ladies might reassert their authority and use their social and moral influence more powerfully toward the reorganization of Richmond society.

If successful, this inter-class "dialogue" at the receptions between the elite and their inferiors could contribute significantly to the fluid operation of society. As the newspapers and leading ladies imply, such success lay rooted in each class's proper adherence to and execution of a familiar set of prescriptions for dress and behavior that clearly conveyed the identity of an individual, but allowed him or her to negotiate, however silently, with members of the other classes on behalf of their respective interests. For the poor, those interests often revolved around

284 T. J. Jackson Lears, “The Concept of Cultural Hegemony: Problems and Possibilities," The American Historical Review 90, no. 3 (June, 1985), 567-593; Genovese, 6, 26-7; Isaac, 337-339. 
food, shelter, and furloughs for husbands and sons. For the elite, their interests largely revolved around the attainment of social and political power and the ability to mold society to their hierarchical liking.

The Presidential receptions were so attractive to Richmonders that they attracted increasingly larger crowds as the years wore on. However, the Davises' commitment to opening their house to truly any member of Richmond society eventually reached its tipping point. On January 19, 1864, the Confederate White House fell victim to an act of suspected arson during what had become, by then, a weekly reception. There has been disagreement, both at the time of the incident and among current scholars, as to whether the fire was an accident or a true act of arson, and whether the arsonist was a guest or a disgruntled domestic slave. During the fire, Henry, one of the Davis family slaves ran away. However, it is not clear as to whether he may have set the fire as a distraction so that he could escape, or whether he may have simply taken advantage of the fire as an opportunity to do so. Regardless, this incident gave the Davis family understandable pause. The Davises were shocked by this reaction (be it from a white person or from a slave) to their hospitality, and expressed a heightened concern about the throngs of strangers being admitted into the Presidential mansion. ${ }^{285}$ As a result, the Davises curtailed their weekly receptions, but nevertheless continued to host both annual and multi-annual receptions, believing that the benefits of such gatherings far outweighed the risks.

In the minds of Varina and the leading ladies, an additional and significant benefit of the receptions lay in that ability to improve the morale of the city, but also the morals-and thus social behaviors — of Richmonders by spotlighting and celebrating elite attendees' performances of respectable behavior. As historian Amy Minton convincingly argues, the quest for attaining and maintaining respectability was a unifying and inspirational force among nearly all 
nineteenth-century southerners from various classes, and especially women. ${ }^{286}$ Thus, although Richmond's ladies desired to maintain a permanent social distance from their inferiors, they were well aware that they served as a model of propriety and an inspiration to many of their social inferiors who, likewise, sought to attain such respectability. Admittedly, for some of these women's critics, the ladies' dress, mannerisms, and comportment seemed pretentious and inappropriate for wartime, and thus, unwittingly undermined the very instruction and inspiration that the ladies sought to provide. To many of these critics, "respectability" implied piety, selfrestraint, sobriety, and a genuine showing of concern for others — not necessarily a lavish display of flashy finery. Additionally, for the most impoverished women, the struggle for mere survival clearly trumped any desires toward achieving such distinguished social ranking. However, as Minton stresses, regardless of their personal feelings toward the elite themselves, middling and lower-middling women shared the elites' desire for respectability and surely aspired to promote their own social ranking, if only marginally, in Richmond society.

Highly conscious of being "on display" before both their peers and the public, Richmond's leading ladies viewed the public receptions similarly to how they viewed house visits, parties, theater-going, charity, and certain holiday celebrations: Cultural rituals in which their execution of their roles and responsibilities as respectable, dignified ladies had the potential to bolster not only their own social authority, but also the morality of any public onlookers. Thus, the ladies and their gentlemen arrived at the receptions consciously clad in beautiful finery; engaged in graceful conversation with their equally as impressive peers; and practiced a core set of manners which they hoped would both reaffirm their own distinction as societal leaders, but also would inspire and encourage the "indecent" or vulgar, impoverished, and degraded lesser sort—all potential threats to moral living, order, and social stability—to improve

\footnotetext{
286 Minton, ii, 2, 18, 309.
} 
themselves accordingly. As simultaneous morale boosters, social placation, affirmation of elite power, forums for the negotiations of order and for personal interests, and inculcators of moral and social order, public receptions were a significant and highly anticipated social, political, and cultural ritual for elite and poor alike — a ritual that was highly reflective of the continuous reshaping of social relationships, evolving perceptions of cultural authority, and social bartering that defined the wartime experiences of a vast number of Richmonders.

In addition to the promenade and public receptions, Richmond's leading ladies also looked to the theater as a venue at which to showcase their prominent social status while simultaneously striving to impose clear delineations within the public social order. As was true for many nineteenth-century cities, Richmond enjoyed a rich tradition of public theater, but also dealt with myriad social disturbances during performances due to the diverse and often raucous individuals who frequented the theater. As Lawrence Levine notes, the ritual of American theater-going had long been celebrated in the early Victorian era as an expression of democracy and a hallmark of "free" society. A public space that stood open to anyone who could pay for admission, the theater served as a unique gathering spot for members of all classes of society who were able to jointly partake in both the performance's entertainment and its educational value. Indeed, elites, soldiers, the poor, free blacks, and even slaves frequently populated the theater simultaneously. Musicals, plays, operas, and other theatrical performances served the interests of high and low audiences alike. Attracting a true cross-section of society to its performances, the theater essentially was a microcosm of the larger community. Thus, many of the social tensions, divisions, and challenges inherent in a nineteenth-century city—and 
particularly one at war-likewise plagued the theater-going crowds. ${ }^{287}$

Victorians valued Shakespearean productions, in particular, as easily relatable, humorous, and morally instructive plays that enabled Americans of all backgrounds to understand better the nature of complex human relationships and helped Americans deal with difficult issues such as race, slavery, and class tensions. ${ }^{288}$ Additionally, early-nineteenth-century theatrical productions encouraged the active participation of the audience in both determining the content and the plot of the performance, which allowed for mass democratic participation in determining the outcome of the show. ${ }^{289}$

Although the theater was generally divided into three tiers of seating according to race and social class, during the first half of the nineteenth century celebrations of the democratic qualities of the theater largely trumped upper-class concerns about decorum and excessive rowdiness at theatrical performances. ${ }^{290}$ However, by approximately 1850 , the sheer number and diversity of strangers who attended theatrical performances began to taint the experience of many theater-goers who grew increasingly upset at the uptick in riots, shouting, throwing of vegetables, and other raucous behavior during the shows. Upper-class disillusionment with public theater resulted in the increased segregation of seating and other public space at the theater, more regulation attendance and crowd participation by special "watchmen," and a revision of the types of theatricals performed at public venues in order to promote order, decorum, and moral behavior. The carefully crafted division of public space within the theater according to race and social privilege, and the performative aspect of theater attendance itself,

\footnotetext{
${ }^{287}$ Lawrence Levine, Highbrow/Lowbrow: The Emergence of Cultural Hierarchy in America, The William E. Massey Sr. Lectures in the History of American Civilization (Cambridge: Harvard University Press, 1988), 21, 68, 39, $24,26,29$. 288 Levine, 21, 68, 39.

${ }^{289}$ Levine, 24, 26, 29.

290 Levine, 9.
} 
thus began to remake the "democratic" practice of theater-going into a ritualistic delineation of class, race, and gender. ${ }^{291}$ When even these new regulations failed to curtail the general raucousness of the theater, the wealthier and more "respectable" members of society began to withdraw from public theater-going. Instead, these individuals began to frequent more exclusive performance venues such as opera houses and music halls, but also hosted their own theatricals at private homes where they could indulge in moral entertainment without the harassment of the riff-raff. ${ }^{292}$

The transformation of the theater into a symbolic space wherein the tiered seating of the patrons visually reinforced the "appropriate" class delineations within Richmond's social hierarchy, and the conversion of theater-going into a collaborative social performance of class, racial, and gender identity was evident in Richmond by the start of the Civil War. However, it appears that the rapid expansion and diversification of the city during the war itself played a major role in how Richmond's theater scene and the ritual of theater-going in that city evolved so dramatically by 1865 . Throughout the war, the city's newspapers illustrated Richmonders' growing concerns over the debasement of the theater and the degradation of the theater-going crowd, as well as the threat that such degradation posed to society. Numerous editorials and analytical reports on the theater and its various attendees appear in most editions of the city's daily papers. In fact, proper management of the city's theaters and controlling the theaters' influence on the morality and social order of the city appears to have ranked as a top priority during the war. The theater proved such an influential and representative cross-section of the city that to control the diverse social scene at the theater was, in essence, to control the behavior and order of society at large.

\footnotetext{
291 Levine, 24.

292 Levine, 56, 101, 114, 176-7.
} 
Throughout the war, as noted in both the newspapers and in the ladies' own diaries and letters, ${ }^{293}$ Richmond's leading ladies attended a variety of theatrical productions. Furthermore, during their theater visits, they appear to have strictly adhered to the updated regulations about dress, decorum, and seating. Their continued attendance and adjusted behavior at the theater attests to their own interest in taking part in the theater's collaborative re-delineation of racial, class, and gendered order, (while continuing to enjoy their favorite theatrical performances, of course). The ladies' patterns of attendance at various theatricals throughout the war, and their adherence to specific social guidelines during such productions, illustrate yet another set of social rituals in which the female elite engaged in order both to reaffirm their own social privilege and to reinforce the city's precious social hierarchy which the chaos of war continued to imperil.

From the start of the war, Richmond's ladies turned out in force at the performances held at Richmond's various theaters, both to enjoy the public entertainments and to contribute to the charitable causes in whose name several of the performances were held. A September 13, 1861 performance of music and drama at the Metropolitan Hall, located near Franklin and $14^{\text {th }}$ Streets (near the Capitol) drew 1200-1500 people, including "many ladies who came for noble charity." ${ }^{294}$ Undoubtedly the ladies were interested in supporting the city's war-time charities for soldiers and their families - and took great pains to ensure that the public noticed their contributions to such charity, as is discussed in chapter four. Ladies' continued presence at charitable concert events held even at such venues as Franklin Hall and the First African Church

\footnotetext{
293 Newspaper citations listed in following pages. For diary citation examples, see Chesnut, 564; Virginia Clay to “Celeste," May 16, 1863, C.C. Clay Papers, David M. Rubenstein Rare Book \& Manuscript Collection, Duke University Library; Cary, 178.

294 Richmond Examiner, September 13, 1861.
} 
attests to their dedication to supporting patriotic charities. ${ }^{295}$

However, it is interesting to note that the ladies carefully selected which performances to attend at which venues. Disgusted by the thought of appearing at a "stupid drama" or "base entertainment," the ladies frequented certain venues and specific types of performances much more than others. Their careful selection of venues and performances reflected not only their personal preferences in entertainment, but also highlights their attempts to promote moral education and entertainment through their patronage of "approved" amusements. It is no surprise that the ladies most often chose to attend morally uplifting performances at venues where their presence would be especially conspicuous, and where the seating for the various attendees was strictly ordered according to race and social class. Thus, quite expectedly, the city's most fashionable ladies more often appeared at the cultivated musicals featuring celebrities such Ella Wren and Ida Vernon held at the Marshall Theater than at the farces and minstrel shows held most regularly at Metropolitan Hall and the Varieties. ${ }^{296}$ Likewise, upscale performances of works such as Antonio Torriani's famed Italian operas attracted a spare, but highly fashionable audience at Richmond's more exclusive theaters. ${ }^{297}$ By symbolically segregating the crowds of the rowdier or more "base" theaters, such as the Varieties (and occasionally the Met), from the more virtuous attendees at the more upstanding venues, the ladies — at least temporarily_-succeeded in imposing elements of social order upon the city.

The city's Marshall Theatre (also known as the Richmond Theatre) proved an especially attractive performance venue for Richmond's ladies. All through the war, but especially during the first couple of years of the conflict, this large and more socially-segregated theatre was

\footnotetext{
295 For citations, see following pages.

296 Richmond Examiner, October 10, 1861, October 11, 1861, December 5, 1862, December 11, 1862, December 15, 1862.

297 Richmond Examiner, October 16, 1861.
} 
known for attracting a diverse audience and for its moral plays, such as the popular play "Camille," which features the story of a fallen woman and society's efforts to improve her into a noble member of society, as well as numerous Shakespeare plays. ${ }^{298}$ The nature of the performances at the Marshall deemed this theatre an appropriate venue for the ladies to frequent. The rigid segregation of social space and the diverse elements of society that the theatre attracted also made the theatre an appealing place for the ladies to go to showcase their own social privilege and respectability in the exclusive dress circle and private boxes, and thereby also help to reinforce both social and moral order within the city. Attendance at the Marshall's theatrical productions thus served as both an elite privilege and a social responsibility for the city's leading ladies.

However, it did not take long for even the Marshall to fall victim to the moral corruption and vice infesting the newly minted Confederate capital. On December 11, 1861 the Richmond Examiner printed a piece that expressed the public's concerns over the excessive amounts of drinking occurring at the bars in the Marshall. In fact, the article feared that attendees' abuse of the theatre bars was altogether "changing the spirit of Richmond" by allowing attendees to become so intoxicated that shootings during theatrical performances were becoming more commonplace and passers-by could almost expect to see rowdy, stumbling drunk men roaming the sidewalks around the theatre after the nightly performances. ${ }^{299}$ "Bloody affairs" between roughneck soldiers, loafers, and other social outcasts on the second tier of the theatre (which was often reserved for those middling to lower-middling elements of society) and other violence ultimately resulted in the city government calling in the state guard to prevent further uproars at

\footnotetext{
298 Richmond Examiner, December 4, 1861, December 11, 1861.
}

${ }^{299}$ Richmond Examiner, December 11, 1861. 
the theatre. ${ }^{300}$

Debates weighing the moral benefits and costs of the theatre and its ever-popular bars raged in the city newspapers that winter as Richmonders desperately sought a way to control the more raucous theater-goers while still opening the venue's doors to patrons of all classes to partake in its musicals and dramas. Such debates climaxed when, on the evening of January 2, 1862, the Richmond Theatre burned to the ground as a result of a suspected case of arson by one of its former "rowdies," whom the Richmond Examiner proclaimed was "undoubtedly" a Baltimore refugee. ${ }^{301}$ While some called the "incendiary's torch" an instance of "Divine Providence" and breathed a sigh of relief at the destruction of the city's largest and most troublesome theatre, other flocked to the city's other performance venues, such as Franklin Hall and the Richmond Varieties theatre, located below the Exchange Hotel near $14^{\text {th }}$ and Franklin Streets. $^{302}$

As Richmond's smaller performance venues began to expand in 1862, so did episodes of drunken, violent, and other unsavory behavior at these various sites. Richmonders continued to fret over the poor influence of the theaters and the kinds of attendees they attracted upon the moral fabric of the city. The increasing number of "suspicious" refugees, rowdy soldiers, prostitutes, and African-Americans at the city's various theaters caused great concern, as did the increasingly bawdy nature of some of the performances at the Varieties and the Met. On February 5, 1862, a performance at the Met was broken up by a fight in the gallery (a space reserved for prostitutes and other lowly members of the community) during which several attendees fired their pistols, leapt from the galleries, and jumped from the venue's windows in

300 Richmond Examiner, December 30, 1861.

301 Richmond Examiner, January 3, 1862.

302 Richmond Examiner, January 4, 1862. 
order to escape the danger. Following the disturbance, the crowd poured out of the theater, and "for 15 hours afterwards in the neighborhood, the night was made hideous with drunken revelry and lawless riot." 303 After several additional shooting riots at the Met later that month, including the stabbing of a black man by another of the crowd's 100 black attendees, the Examiner raged, "why is this miserable den not closed by the authorities? Nearly every night there's been a disgraceful row... [it is] a gathering place for drunks and rowdies to gather and stab and shoot at each other.",304

The moral decline of popular theater in early 1862 pushed Richmond's leading ladies away from such debased venues toward other performance halls where, through their approval of certain venues over others and their conspicuous self-seclusion, they sought to salvage and promote the morals and moralizing influences of public theater. Their silent, though symbolic, retreat from particular theatrical venues to other, more "appropriate" places of entertainment reflects their efforts to re-delineate not only the social tiering of performance venues, but also the social order of public spaces as a whole. The institution of martial law in Richmond that March temporarily had helped with a reduction in crime at the theaters. However, the constant influx of newcomers, and the never-ending supply of whiskey, prostitution, bowie knives, and pistols, continued to fuel the degradation of many of the city's public theaters.

Interestingly, the ladies immediately chose to rally around the performances of the visiting famed musician, "Blind Tom," a blind African-American piano prodigy who toured the nation, consistently wowing his audiences with his musical skills and entertaining prowess. Blind Tom performed exclusively at the African Church in Richmond, where he received some

303 Richmond Examiner, February 5, 1862.

304 Richmond Examiner, February 26, 1862, February 4, 1862. 
of the largest crowds ever recorded at a show in Richmond during the war. His shows were so popular, in fact, that he had to organize special matinee performances specifically to accommodate the sheer number of ladies and children who wished to see him in action. ${ }^{305}$ The Examiner reported that "Blind Tom is so astoundingly good, some people refuse to believe him a bona fide negro...he attracts the most cultivated of society." The paper assured concert-goers that he was indeed a "genuine nigger," but that his skill was just particularly "marvelous."306

The ladies' widespread support of Blind Tom seems rather curious, considering their previous preference for more classical, traditional, all-white entertainment. However, as the Examiner reported, the "dearth of a better class of public amusements" forced the ladies to find entertainment and meaning in more diverse performances. The shift in interest toward Blind Tom reflected a restructuring of the way in which the ladies perceived certain entertainments and the symbolism of their attendance thereat. The ladies' newfound enthusiasm for Blind Tom thus represented a change in theatrical taste and the elites' embrace of a new way to delineate class, privilege, and social order. The concerts of Blind Tom attracted a certain class of individuals who could appreciate his "divine" musical skills, so the ladies could rest assured that the rowdiness of the Met and the Varieties would not soon infiltrate Blind Tom's church performances. However, the ladies' deep fascination with an African-American performer, and their acceptance of regularly going to see him within a space specifically dedicated to AfricanAmerican worship is particularly interesting.

Because the ladies' own writings about their visits to see Blind Tom are so spare, one can only make conjectures about why they made such an effort to attend his performances.

305 Richmond Examiner, February 3, 1862.

${ }^{306}$ Richmond Examiner, February 6, 1862. 
Obviously, Blind Tom's concerts provided necessary entertainment during the long and miserable war. However, the ladies' specific choice to attend his concerts over the many other concerts being offered at smaller venues throughout the city seems to suggest that they found a unique satisfaction and comfort in the performances of Blind Tom. In analyzing the ladies' attendance of Blind Tom's concerts as a sort of cultural ritual, it is evident that the ladies' avid support of a black entertainer resembles similar patterns of white masters' and mistresses' indulgence in (modest) black minstrel shows, performed to different degrees of formality both within the "big house" for private social entertainment and on the public stage for mass enjoyment. Such minstrel-esque performances were a staple of many whites' lives prior to the war, and provided elite white viewers the opportunity to take delight from their chattel by simultaneously reinforcing the racial power dynamics of white privilege. By encouraging their racial inferiors to perform for them, and in avidly supporting such performances, whites were able to perform their contractual duties as "caring" and "supportive" guardians of their "black children" through their allowance of black indulgence in such revelry, while simultaneously reinforcing their power over their black entertainers.

Richmond ladies' conspicuous and forceful support of Blind Tom's performances appears to be an expression of the ladies' fallback upon familiar practices of that paternalistic indulgence of and in black entertainers. Such indulgence suggests a desire and effort by Richmond's ladies to return to the traditional social practices and moral ordering of the pre-war era that had been so confounded by the chaos of war. The ladies' continuous support of Blind Tom's entertainments would have helped to remind the public of the social power accorded to the ladies, as moral arbiters, by the institution of slavery and their husbands' role as slave master. However, in the minds of the ladies, their constant attendance might also encourage socially 
deviant or threatening whites to reunite along lines of racial privilege as the consumers of black production, and in this case, entertainment. Thus, the ladies' patronage of Blind Tom may have served as an escape from the social disorder of the city's other, more bawdy theaters. The ladies also might have used their patronage as a means to quell elements of white social disorder by promoting a common unity as "privileged" white consumers of the products of their black inferiors. Additionally, the ladies may have hoped that their conspicuous, paternalistic support of the Blind Tom concerts might help reaffirm, both for themselves and for the general public, the traditional and clearly demarcated privileges, responsibilities, authority with which they, as the moral co-guardians of slavery and Richmond's slave society, were invested. In turn, the ladies' strong showing of support for Blind Tom's artistic cultivation and personal uplift as a skilled performer may have sent a clear message to the broader community that the elite would patronize, and thus help ensure the success of, lower members of society if they put aside their tendencies for rowdiness, vice, and violence and instead worked toward their personal betterment through deference to their elite leaders.

The Civil War clearly helped to spur on Blind Tom's success as a performer, as it, both directly and indirectly, created the chaotic physical and social conditions necessary for elite white women to turn specifically back to black entertainment for some sense of reaffirmation of the proper social order. The war also produced additional forms of theatrical entertainments, such as military brass band concerts, war "dioramas," tableaux, and other productions that elite women chose to patronize both for entertainment and as a way to project a social order upon war-torn Richmond. Regimental band performances, as well as Lee Mallory's famous "War Illustrations," a revolving diorama depicting dramatic scenes from the war such as the firing on Fort Sumter and the Battle of Manassas, proved to be popular productions where the ladies 
regularly put themselves on display as the patriotic supporters and social guardians of the proud Confederacy. $^{307}$

The ladies' conspicuous appearance in the first tier at the Met during showings of "War Illustrations," or in prime seating at various churches and performance halls during the grand brass band concerts, both charitable and otherwise, not only showcased the ladies' status as elite societal leaders, but also reaffirmed their entitlement to such status and privilege through their patronage of wholesome, patriotic events. As discussed in earlier chapters, such privilege was frequently critiqued by both the tide of incoming, impoverished refugees and even some of their own peers during times of immense suffering in the city. Additionally, the ladies may have intended their highly-conspicuous patriotic support of the Confederate "cause" to inspire other, more lowly members of society toward similar productive, patriotic activities rather than toward indulgence in the dangerous vice and crime that the war also brought to the city.

Although the ladies patronized select performances at the Met, the African Church, and even on occasion, the Varieties — venues generally regarded as for the "lesser sorts" only_ throughout the war, their primary appearance at public performances from 1863 onward occurred at the New Richmond Theatre, which opened in January, 1863 on the corner of $7^{\text {th }}$ and Broad. Built essentially in the footprints of the old Marshall Theatre, the New Richmond Theatre emerged as the pinnacle of fashionable, yet democratic, theaters. Its managers prided themselves on offering first-class performances that, unlike some of the other theatres in town, would both entertain and uplift society. A towering sixty-six feet high and fifty-five feet wide, the New Richmond Theatre featured beautiful classical décor and, more than any other Richmond theatre

307 Richmond Whig, April 3, 1863, February 21, 1863; Richmond Examiner, March 28, 1863, March 17, 1863. 
in the past, delineated both its seating and its every passageway according to class and race. ${ }^{308}$

With five doors for public entrance, including private doors for entry into the exclusive proscenium and box seats, a special vestibule and center ticket office reserved just for use of elite attendees in the parquette and first circle, and two additional circles — each with its own set of tiers - the New Richmond Theatre was a formidable model of social order. All attendees were allowed — and encouraged — to enjoy the lavish corinthian columns, red damask seat cushions, fresco paneled walls, handsome balconies with gilt iron railings, and abundant flowers that contributed to the theatre's radiance. Such elaborate décor also was intended to impose a feeling of refinement and respectability upon all classes of attendees in order to encourage good behavior and order during the performances. However, the rigid delineation of the seating and footpaths, combined with the installation of a lobby in the upper dress circle specifically for promenaders, provided a comforting sense of social order for elite attendees who constantly felt barraged by the increasing population of war vagrants, rowdies, and refugees flooding the Confederate capital and by the omnipresent vice, vulgarity, and crime that such newcomers brought with them into Richmond. ${ }^{309}$

Tiered prices for each level of seating also helped to ensure that proper social order existed within the theater. According to a February 9, 1863 edition of the Richmond Whig, the theater charged a whopping fifteen dollars for a private dress circle box and twelve dollars for a family circle dress box, with prices dropping significantly thereafter to one dollar and fifty cents for balcony and orchestra seats, one dollar for a lower dress circle or parquette box, seventy-five cents for a second tier seat, one dollar and fifty cents for a third circle private box, one dollar for

\footnotetext{
308 Richmond Examiner, December 23, 1862.

${ }^{309}$ Richmond Examiner, December 23, 1862.
} 
a third circle public box, one dollar for the "best" colored boxes, seventy-five cents for second grade colored boxes, and fifty cents for the colored gallery. A unique rule which further emphasized the power of Richmond's ladies to define the social order within society stated that no one was admitted to any of the dress circles unless accompanied by a lady. Therefore, ladies possessed the singular ability to define who was morally and socially worthy of a place within the dress circle — and, by extension, into elite society — through the mere acceptance or decline of a gentlemen or fellow female's proposal to sit in the exclusive tier of seating in the theater. Ushers greeted the ladies and gentlemen seated in the upper dress circle, and for an extra twentyfive cents, these upper-class attendees could reserve their seats in advance. ${ }^{310}$

The New Richmond Theater also prided itself on a core set of strict new rules to ensure proper order during performances. According to the Whig, attendees were to observe the "strictest order and decorum; that, by the Mayor's decree, the partaking of liquor to the annoyance of the crowd" was strictly prohibited; smoking, putting one's feet up on a seat or railing in front of them was not allowed, and that excessive noise would not be tolerated. Anyone who violated these strict rules was to be ejected and placed in the watch house "to answer to the Mayor." The theatre declared its "elegance and comfort unmatched," and vowed to produce only the best ballets, Shakespeare plays, grand tableaux, music medleys, orations, comedies, and concerts that would most please the most distinguished members of its audience. ${ }^{311}$

The New Richmond Theater was wildly popular amongst the city's leading ladies whose frequent and ritualized attendance at the theater gave a silent, but forceful, approval of the

310 Richmond Whig, February 9, 1863.

311 Richmond Whig, February 9, 1863. 
venue's strict system of social ordering. Dressed in their most fashionable finery, the ladies paraded, in clear view of the public, along the upper dress circle promenade and relished the privilege to conspicuously cleave off from the theater riff-raff into the exclusive stairways and passages that led to their highly coveted seats. The ladies' clear visibility, yet equally as clear separation from the lower classes at the theater thereby reinforced their own class privilege while making a forceful statement to theater-goers about the strict moral and social rules governing the hierarchical ordering of society.

The ladies' flashy arrivals at the theater in elegant carriages and on the arms of the city's most dashing politicians and generals, and their flaunting of finery from the exclusive seats of the upper dress circle also served to reinforce the social mores that the elite believed should regulate society and its separation into various classes and social rankings. In continuously displaying themselves as models of elite feminine virtue during these highly ritualized visits to the theater, the ladies thus attempted to impose upon fellow theater-goers - a true cross-section of society — the need for and the benefits of moral living during a time of war that seemed to confound even the most basic traditions of social order and virtue. In this way, the ladies complemented the refined new décor of the theater as not only models of respectability, but agents of propriety.

The New Richmond Theater was not always a peacefully ordered and clearly delineated public space, however, proving that, as much as the ladies tried to impose morality and social order upon the theater-growing crowd, they often were unsuccessful. The popular theater was often packed with the less desirable elements of Richmond society. While roughneck soldiers, drunks, and other rowdies began to infest this so-called "temple of drama," rebellious blacks and the city's burgeoning number of prostitutes posed a particular threat to the prized social order of 
the theater. Although these undesirable members of society had seemed to find their way into the galleries and third tiers of the city's theaters since the start of the war, their invasion of the "respectable space" in the New Richmond Theater from 1863 onward produced particular annoyance and concern among Richmond's elite class of theater-goers. Much to the true ladies' horror, prostitutes (disguised as "ladies") began appearing on the arms of Confederate officers in the theater's exclusive boxes. The "virtuous excitement" of Richmond's true ladies over the ejection of prostitutes from the dress circle became quite legendary at the New Richmond Theater during the summer and fall of 1863. Eventually, the presence of prostitutes in the upper dress circle became so troublesome that the theater ultimately called forth the police to stop the show, remove the soiled doves, and have the "whole place fumigated" (perhaps metaphorically) before the show could restart. ${ }^{312}$ Theater officials also responded to numerous complaints from wealthy attendees who discovered black men and women in white-only designated seats. Like the prostitutes, these black social deviants were immediately and forcibly from the premises. ${ }^{313}$

It is interesting to note that such ejections did not usually occur without a respectable attendee-either a true lady or her gentleman escort — alerting the police of the issue and calling for a dramatic removal of the offending woman from the theater. The active roles that ladies played in physically removing indecent women from the elite's exclusive social sphere made them even more forceful, conscious, and ever-policing watch-women of the theater and true guardians of the social order maintained therein. Although the ladies continued to attend performances at the New Richmond Theater, and thereby continued to contribute to the upholding of proper social and moral order amongst the diverse attendees of the theater, the quality of the performances began to decline by late 1863 .

312 Richmond Examiner, June 1, 1863, October 12, 1863.

313 Richmond Examiner, November 16, 1863. 
Under the direction of its new manager, a Mr. Dorsey Ogden, or "D'Ogden," the theater began producing a slew of mediocre shows that ranged from dull to "stupid" to morally base. D'Ogden received the criticism of the masses for leading the new theater dangerously close back to its old Marshall roots. The increasing number of lowly attendees proved such a stable source of income for the theater that D'Ogden recentered the focus of his productions on what the Whig called "bawdery and ribaldry." A December 31, 1863 issue of the Whig went on to criticize D’Ogden, once the moral elevator, as the moral decimator. D'Ogden, the Whig lashed out, had made the New Richmond Theatre a "cess-pool" where the moral and legitimate drama of earlier times had been forsaken for "depravity, high skirts, flesh colored tights, low cut dresses, vulgar tongues, excess, and lasciviousness." The theater, the paper proclaimed, was now always filled only at the expense of virtue. The Whig went on to accuse the inculcation of moral laxity at the theater of infecting the community at large: "The times are perverse and vicious, and immoral enough without the help of the theater" that was as corrupt as "those in Paris and New York where they cater to the third tier." Something had to be done, the paper stated, to either shut down the theatre entirely or return to it the moral dramas and performances that it was meant to showcase. ${ }^{314}$

Whether the theater was truly a primary cause for the city's increasing vice and immorality or not, the social problems that plagued the theater appear to have mirrored those within Richmond society as a whole by mid-war. In an attempt to regain the favor of Richmond's wealthy patrons, D'Ogden reintroduced a series of classic Shakespearean plays and even some operas in the spring of $1864 .{ }^{315}$ By the Fall of 1864, the New Richmond Theatre stood, once more, at the forefront of Richmond's performance venues. Richmond's ladies

314 Richmond Whig, December 31, 1863.

315 Richmond Whig, March 3, 1864, March 25, 1864. 
showcased their own dedication to charity, their legitimacy as patriotic social leaders of the Confederate nation, and their continued support for the maintenance of moral and social order in Richmond through repeated, large-scale turn-outs at the New Richmond Theater's complimentary benefits for soldiers and the poor that winter. Paying ten dollars per ticket, the ladies packed the house of the theater, strutting about in their finery, and silently enforcing the theater's strict code about social delineation and order. ${ }^{316}$

Yet, while some ladies continued to attend select charity performances, as well as a sampling of traditional musicals, moral dramas, grand concerts, and military-themed productions at the New Richmond Theatre, and even occasionally at the Met or the Varieties $^{317}$, many ladies began to withdraw from their routine visits to the city's public theaters. Instead, these ladies sought out entertainment and companionship at private theatricals hosted in the elegant homes of the city's capital elite. ${ }^{318}$ The ladies' withdrawal from public theater roughly mirrors their inward-turning tendencies toward exclusive parties and increased reliance on exclusive home visits during the late war period. Their retreat from the public sphere may have occurred for a multitude of reasons, including personal grieving; depression over the failing fortunes of the Confederacy; and disillusionment with the continously incoming flow of seedy individuals with dubious morals who continued to flood the city's streets and public houses of entertainment, bringing all of their questionable and less desirable qualities along with them. ${ }^{319}$

However, the ladies' withdrawal from the theaters also may have resulted from the scorn and criticism that they received from the city newspapers, their husbands, Confederate soldiers

316 Richmond Examiner, December 28, 1864, December 29, 1864.

317 Richmond Examiner, April 3, 1863, April 2, 1864, April 7, 1864.

318 Putnam, 270.

319 Richmond Enquirer, November 11, 1863; Withers, 102. 
on the front lines, and even from some of their own female peers. Richmond's ministers from various churches also criticized the frequent theater-going habits of the elite. ${ }^{320}$ As early as February 9, 1863, Reverend Burrows of the First Baptist Church began his first of several sermons on the evils of the New Richmond Theater, arguing that, especially in the third tier of the theater, sin and vice reigned supreme. Not only was such obsession with theater during a time of war inappropriate, he argued, but attending a performance at a venue where the immoral behavior of the third tier infected the entire atmosphere of the theater was purely sinful. The front doors of the theater, Burrows cautioned, were the "entrance doors to the gates of Hell!",321

Later that year, on Christmas Eve of 1863, the Examiner printed a piece on the upcoming holiday amusements at the theaters and the ensuing festive refreshments that the theaters and other places of public entertainment would undoubtedly serve to merry-makers. The Examiner sharply remarked that "only the thoughtless will really indulge" in such amusements during such a dark hour for the Confederacy, and that truly Richmonders should refrain from such foolish merry-making, even at Christmas, during such a trying time for the South. ${ }^{322}$ On May 20, 1864, the Examiner reported that the New Richmond Theater had temporarily closed altogether due both to personnel issues and to the unpopularity and perceived inappropriateness of theater-going during the relentless, bloody battles of the Overland Campaign that spring. "What need have we of tragedy and murder on paper and stage when we have the real thing?" the paper bemoaned. "Why should we need farces and ghosts [when] reality is all around us?"323 Meanwhile, the caustic remarks of Phoebe Pember and Willie Pegram about merry-making during the dark and despondent days of war continued to filter in alongside the sentiments of Judith McGuire and

\footnotetext{
${ }^{320}$ Harrison, 178.

321 Richmond Examiner, February 9, 1863.

322 Richmond Examiner, December 24, 1863.

323 Richmond Examiner, May 20, 1864.
} 
James Chesnut, who (as mentioned in chapter two) grew utterly despondent and, indeed, embarrassed over the many sorts of inappropriate public merriment and gayety in the city, especially during the last year of the war.

As the ladies retreated to the safety of each other's homes to indulge in private theatricals, they acknowledged the legitimacy of their peers' concerns. However, as discussed in chapters one, two, and five, even their private theatricals became public knowledge, as the downtown stores bustled with ladies excitedly shopping for costumes and set pieces and the streets surrounding Capitol Square thronged with ladies traveling to and from these amusements. In retreating to their own homes for theater, the ladies hoped to demonstrate to society their own rejection of the degraded state of public theater and the inappropriateness of such base public amusements, and thereby encourage others to reject it similarly. In its place, the ladies championed what they believed to be the modesty and morality of their own private theatricals. However, through their withdrawal, they also were able to segregate themselves more appropriately — and undoubtedly more comfortably—from the dross of common society. In the peace of each other's homes, the ladies could themselves act out moral plays of their own choosing while reaffirming their collective social privilege amongst their "own" high society.

By indulging in private theatricals, Richmond's ladies found social and emotional sanctuary, as Mary Chesnut and LaSalle Corbell Pickett attested to in their passionate defense of elite parties and merry-making during the miseries and weariness of war. The ladies' continued dedication to theatricals, even within the privacy of the home, speaks to the ladies' additional reliance upon the theater for their own class unity, moral uplift, contentment, and peace of 
mind. ${ }^{324}$ These women were not alone in defending their needs for the continuation of theatricals. The Southern Punch, though usually a critic of the extravagant habits of the city elite, argued strongly in favor of the continuation of all theatricals at all cost during the war, stating, "why, amusement of every legitimate character should be encouraged during war as well as peace...Every highly cultivated people have encouraged amusements, because they keep alive a taste for literature and art.” Interestingly, the Punch also argued that nightly engagement in theater would, overall, reduce the amount of crime and vice in which bored and unstimulated individuals might otherwise engage. But most of all, the Punch argued,

everything should be encouraged that tends to keep our people from brooding over the calamities incident to war. Amusements, aside from being enemies of the doctors, in a great measure prevent despondency by superinducing much exhilaration of the spirits for hours together. While civilians and soldiers keep light hearts, the victory is with us. ${ }^{325}$

Likewise, the Richmond Enquirer remarked in June of 1862 that, during the war more than ever, the city was in need of amusement to "relieve the mind" of "dull tedium and monotony," and to "have the virtues of good extolled and rewarded and the guilty punished." Theater, when properly conducted, the editors argued, "leads to elevation and instruction of the mind." The Enquirer even went so far as to state that, "in other countries where war was waged and sorrows and bereavement felt, the necessity of amusement for the people was so apparent that to check their indulgence would be equivalent to defeat for all" and would "cast the gloomiest shadow." The editors continued to plead with their readers for renewed support of the theater to "encourage and inspire the less volatile, and if the drama can produce such an element, let it go on without hindrance." ${ }^{326}$ Even General Winder, the Commander of the Department of

\footnotetext{
324 Rable, 192.

325 Southern Punch, August 15, 1863.

${ }^{326}$ Richmond Enquirer, June 4, 1862, June 15, 1862.
} 
Henrico, argued that it was "important to have theatre to laugh at in tough times" as it is "good for the moral and intellectual advancements...the public must have amusements.",327

The ladies' continued engagement in theater, both public and private, speaks to their multiple uses of theatricals to inculcate order, virtue, and morale in Civil War Richmond. Well aware that the maintenance of proper social order in Richmond relied heavily upon the strength, unity, and ability of the capital elite continue to serve as moral arbiters of that social order, Richmond's ladies sought from both public and private theatricals the power and endurance to fulfill their societal responsibilities. As was noted in chapter one, the ladies of Richmond's capital elite faced numerous obstacles in both establishing and maintaining such privilege and power throughout the war. Always contested and critiqued from both high and low, the power held by these wealthy women was never permanent or certain, and they knew it. Through carefully crafted appearances and scripted behaviors at Richmond's most prominent theaters and at home, and through ritualized projections of ladyship during the promenade and on conspicuous, pleasurable carriage rides through the city, the women of the capital elite proudly performed their constantly evolving wartime identities as "true ladies" of the Confederacy. In silent negotiation with their critics and with those whose approval they so desperately sought and needed in order to achieve such high social ranking, and through silent ordering of Richmond society through forceful claiming of symbolic public spaces, Richmond's ladies painstakingly monitored their every appearance and behavior, and adjusted each accordingly as the demands and population of the Confederate capital continued to evolve.

However, as suggested earlier in this chapter, the ladies could not simply lay claim to such privilege through mere force and empty promises of benevolence, with the hopes that their

327 Richmond Examiner, June 1, 1863. 
public self-displays on the promenade and in the theater would permanently guarantee their spot within the capital elite. For that, the ladies carefully studied the scripts of other critical social cultural rituals and stepped onto the public stage in related, but different, roles as Richmond's charitable social guardians and arbiters of moral benevolence. 


\section{Chapter 4-- "To Whom Much is Given, Much is to be Required": Ladies' Charity in Confederate Richmond}

In August of 1861, a finely dressed Mary Chesnut accompanied her friend, Mrs. Randolph, wife of the future Confederate Secretary of War George Randolph, on a visit to the major military hospitals in downtown Richmond. Horrified and disgusted by the shocking scenes of suffering and death that they encountered on their visits, Chesnut wrote, "I can never again shut out of view the sights I saw of human misery...[when] I have enough to think about now." During ensuing visits with the Sisters of Charity to the former city Almshouse (converted into General Hospital Number 1) and to the St. Charles Hotel, recently converted into a large hospital on the corner of Main Street and $15^{\text {th }}$ Street, Chesnut was appalled by the lack of organization at the medical facilities and the awful smells and sights that greeted her at every turn. Eventually overwhelmed by her surroundings, Chesnut fainted clear away and had to be escorted home from the hospital. Realizing that a lady of her status seemed dreadfully out of place at such a site of human suffering, Chesnut quickly suspended the majority of her long hospital visits, and instead performed her "duty to the cause" through brief, weekly, if not biweekly, deliveries of fruit, wine, and other edible delicacies to the city hospitals. ${ }^{328}$

Chesnut's recounting of her experiences with soldier-centered charity does not differ widely from that of her fellow Richmond ladies. Some elite women joined the ranks of the middling classes in serving as hospital nurses and matrons or spent large portions of their days and evenings in sewing circles, making socks, shirts, blankets, and bandages for their soldiers on the battlefield. However, many of Richmond's most distinguished ladies chose to assume a less

${ }^{328}$ Chesnut, 155, 158, 164. 
direct, more formalized, and more symbolic role in public charity during the war. ${ }^{329}$ Such choices reflect the ladies' engagement in specific charitable rituals as a means to contribute to the stabilization of society while also earning the respect and loyalty of their social inferiors. However, such choices simultaneously reinforced the ladies' appropriate social distance from their inferiors by conspicuously reminding those other classes of their elite privileges that sanctioned such distance. As Winchester refugee, Mary Tucker Magill understood it, the "southern sensitiveness upon the subject of feminine delicacy protected them [the ladies] from publicity and the common herd., ${ }^{, 330}$

The ladies' mere engagement in charitable acts clearly helped to bring material aid to society by assisting the Confederacy's soldiers, civilian workers, refugees, and suffering families and individuals who were forced to endure immense sacrifices on behalf of the war effort. Additionally, their work as clerks in the Treasury, Quartermaster, Ordnance, and other governmental departments contributed significantly to the government's ability simultaneously to wage war and provide for both its soldiers and its civilians on the home front. ${ }^{331}$ However, equally as important, the symbolic nature of certain charitable acts such as Mary Chesnut's showcased the ladies of the capital elite as an empathetic, caring class of benevolent women. The wealthy mother of Kate Virginia Cox Logan, a refugee who had relocated to nearby Clover Hill, Virginia but who made frequent trips into Richmond with her parents to assist with public charity in the city during her refugee days, was one of those benevolent ladies. According to young Kate, "during the war...mother and father both never shirked their duty, nor forgot 'to

\footnotetext{
329 McGuire 108, 176, 237; Putnam 154.

330 Mary Tucker Magill, Women: Or Chronicles of the Late War (Baltimore: Turnbull Brothers, 1871), 328.

331 Magill, 328.
} 
whom much is given, of them much shall be required." 332

Richmond's leading ladies believed that their engagement with the less-privileged in a shared sensibility of sacrifice and suffering might help to solidify a stable and peaceful relationship between Richmond women of different classes. To the ladies, their participation in ritualized, charitable performances was a critical means through which to gain the respect and deference of the lower classes and the consent of the middling classes, and thus ensure the perpetuation of elite rule over Richmond society. ${ }^{333}$ The ladies also used these more ostentatious acts of charity to showcase their wealth and privilege before the lower classes of women and thus reaffirm their continued entitlements to social authority.

In turn, Richmond ladies' choice of charities to which they contributed lent legitimacy to certain sectors of society as worthy dependents upon the elites' charity and as morally worthy members of the broader Richmond community. In favoring specific charitable causes over others, the ladies simultaneously helped to distinguished for the public the worthy poor from the immoral "paupers" of society whose depravity and vice threatened to taint the entire social order of the Confederate capital. Thus, while the ladies intended their conspicuous charitable acts to further help solidify their own moral worth as social leaders, they also sought to inspire other Richmonders to recognize the plight of, and themselves assist, the worthy poor. By providing instructive lessons on how to identify and help prevent the spread of immorality and unworthy charity, the ladies hoped to gain control over the rampant social chaos and false claims to charity that could potentially drain the coffers set aside for the worthy poor and might thus result in the dangerous usurpation of society by social pretenders.

\footnotetext{
332 Kate Virginia Cox Logan, My Confederate Girlhood: The Memoirs of Kate Virginia Cox Logan, edited by her daughter, Lily Logan Morrill (Richmond, VA: Garrett \& Massie, Inc., 1932), 71.

333 See, Lears, "The Concept of Cultural Hegemony," and Isaac, 337-9; Fox-Genovese, 232-5.
} 
Analyzing the leading ladies' charitable acts through this multi-faceted lens requires significant interrogation of both the ladies' own diaries and correspondence, as well as of newspapers and the writings of male social commentators, since the ladies rarely wrote so directly about their charitable or performative intentions. As noted in earlier chapters, such silences can be expected in primary sources, as the nineteenth-century southerners' discourse on charity, social projection, and inter-class engagement, as well as their shared sensibilities of honor and duty, often operated within a widely accepted, but rarely vocalized, set of symbolic actions. For the ladies, such symbolic actions often were invested with (what was to them) clear meaning and intent that derived from the "historical bloc" of which all southerners of the Victorian era were a part. ${ }^{334}$

These silences within the sources may also stem from the very real possibility that the ladies did not always consciously think about the full intentions of their actions, but rather occasionally operated more subconsciously within a system of social symbolism and display in which they had been raised and which (thus) constantly, but subconsciously, shaped their actions and behaviors. ${ }^{335}$ To that end, it is important to remember that many of these women's charitable actions were not intended to "dupe" their social others into submission to elite authority, nor were Richmond ladies purely manipulative, uncaring, selfish individuals with constant ulterior motives. Many were mere byproducts of a society and a time period that fostered certain modes of behavior, but also created blind spots as to how their behavior might be alternatively interpreted by outside observers. Thus, this chapter is neither meant to justify nor condemn the charitable actions and intentions of the female elite, nor is it intended to affirm or

\footnotetext{
334 See Daniel Wickberg, "What is the History of Sensibilities"; Isaac, 323-327; Stowe, 2; Lears, "The Concept of Cultural Hegemony," 171.

335 Eugene D. Genovese, The Slaveholders' Dilemma: Freedom and Progress in Southern Conservative Thought, 1820-1860 (Columbia, SC: University of South Carolina Press, 1992), 28, 89; Genovese, Roll, Jordan, Roll, 76, 82; Wyatt-Brown, $124-5$.
} 
deny that such actions, whether the ladies were always fully conscious of their larger meanings or not, proved successful during the war. Rather, the following analysis will serve to further illuminate the broader worldviews and symbolic rituals of the ladies of the capital elite, and specifically, those related to the ladies' unique social roles and responsibilities as charitable leaders of Richmond society.

Prior to the war, Richmond's City Council and the Overseers of the Poor easily fulfilled the needs of the city's relatively miniscule population of paupers. The city Poor House to which the Overseers shuttled the needy for shelter, sustenance, and employment, proved largely successful in keeping the majority of Richmond's streets free of long-term vagrants and the destitute. Paupers were required to apply to the Overseer for relief, and often were forced to supply letters of character reference and proof of state residency for at least one year in order to gain admittance into the poor house. Upon demonstrating that they were members of the "worthy poor," the applicants were accepted into the almshouse. The managers of the poorhouse assumed that their inmates would only live there temporarily until they got back on their feet. Thus, the inmates often had to repay the poorhouse for their care following rehabilitation, or were forced to labor in the factories or on designated farming areas outside the city in order to earn their keep. ${ }^{336}$

Additionally, numerous wealthy women (and men) readily donated significant sums of money to the city's numerous orphanages, including the Female Humane Asylum, which opened in 1805 under the leadership of Mrs. James Wood, wife of the former Virginia Governor, and ran until 1965. Originally built on the corner of St. John's and Charity Street, the home moved to

336 Kimball, 24; Auditor of Public Accounts, City of Richmond, Virginia, "Laws in Relation to the Overseers of the Poor," 1860, Virginia Historical Society (Richmond, VA). 
the corner of $7^{\text {th }}$ and Leigh streets in 1842 where it remained throughout the Civil War. Some of Richmond's most distinguished ladies, including Mrs. Randolph, Mrs. Marshall, and Mrs.

Wickham kept the asylum in operation through generous personal donations and by soliciting the donations of other well-to-do ladies. The Asylum gave hundreds of poor, orphaned girls and young women a decent place to live and a moral education, after which many of the young women were set back on their feet and sent out into society to become respectable women. ${ }^{337}$

Due to the apparently small number of impoverished residents living in the city prior to the war, and due to the city government's successful management and care for the poor through large appropriations to the Overseers of the Poor and to the city Poor House, Richmond's ladies had the luxury of choosing which charities to support and how often to donate to them. ${ }^{338}$ Donations to the Female Humane Asylum and to other, more intimate charitable causes for friends and extended family allowed women the opportunity to support individuals and specific causes that were of particular interest and benefit to themselves as well as to the moral health and order of society. Supporting family (for obvious reason), friends who most likely would return the favor in the future, and "moral causes" such as an orphanage which helped to clean the city streets of their destitute young women, preserve the morality of these young women, and cultivate a new class of respectable young women who might help to bolster the strength and authority of the city's leading ladies, was of great benefit to both society and to the city's reigning ladies themselves.

Additionally, wealthy women believed that such choice charitable actions would help

\footnotetext{
337 “Historical Sketch of Richmond's Oldest Charity, the Memorial Home for Girls, 1805-1925," Virginia Historical Society, Richmond, VA).

338 For exact numbers on Richmond's pre-war population of registered paupers and on the city's pre-war funding for the poor, see Thomas, 24 .
} 
them to win the approval of their social inferiors, as well as the cultural authority awarded to benevolent care-takers who gave willingly of their own resources to support the survival and moral edification of the less privileged. However, the nature of the charitable donations also conveniently excused the leading ladies from being forced to deal directly with the strangers they were assisting or with the broader public on a mass scale. By performing honorable acts of benevolence, southern antebellum women were able to retain their social power and privilege through both their forceful displays of charity and their garnering of the deference of the underclasses whose gratitude and admiration they earned from such displays. ${ }^{339}$

During the Civil War, the sheer number of war widows, orphans, the destitute and the depraved — not to mention the hundreds of thousands of wounded and ailing soldiers — placed an enormous strain on the city's resources to care for the poor. Although the city government continued to extend sizable appropriations to the Overseers of the Poor, and although both the Confederate Congress and the Virginia General Assembly appropriated millions of dollars throughout the war to widows, orphans, and the destitute, such funding still was not enough to cure Richmond of its pauper problems. During the first two months of the war, the new city Alms House on the eastern outskirts of the city provided good food, a wash house, small jobs, and a warm, “cheery," and comfortable accommodations for its inmates. However, following the Confederate Medical Department's takeover of the Alms House in June, many of the city's most impoverished residents found themselves back on the streets. In December of 1861, the

\footnotetext{
339 See Kenneth Greenberg, Honor and Slavery (Princeton: Princeton University, 1996), 65-6, 70, 80-81, 84-5; Bertram Wyatt-Brown, Honor and Violence in the Old South (New York: Oxford University Press, 1986), 124-5, 129; Timothy James Lockley, Welfare and Charity in the Antebellum South (Gainesville, FL: University of Florida Press, 2007), 4, 244-5, 37, 61, 8, 16, 146-8, 169, 174, 217; Christine Jacobson Carter, Southern Single Blessedness: Unmarried Women in the Urban South, 1800-1865 (Chicago: University of Illinois Press, 2006), 118, 120, 149; Genovese, Roll, Jordan, Roll, 51, 58, 4, 110, 71-4; Suzanne Lebsock, The Free Women of Petersburg: Status and Culture in a Southern Town, $1784-1860$ (New York: W.W. Norton \& Company, 1985), 195-236; see also, Elizabeth Varon, We Mean to be Counted: White Women and Politics in Antebellum Virginia (Chapel Hill: University of North Carolina Press, 1998), 10-70; Fox-Genovese, 232-5.
} 
Richmond Examiner reported the arrest of a horde of paupers who had left the Alms House, claiming they had nowhere to stay. These paupers had been caught "roaming the streets in a scandalous manner," and included a group of half-naked women who reportedly wandered the streets during the day. ${ }^{340}$

As war-induced hardships continued to send thousands of unknown strangers flocking into Richmond's city streets that year, the sudden absence of public accommodations for the city's burgeoning impoverished class demanded the widespread charitable aid of Richmond's ladies. Suddenly, in order for Richmond's ladies to win the respect of both their peers and their social inferiors, and in order to preserve the power and legitimacy of the paternalistic system around which all social relationships were based in the nineteenth-century South, the ladies were compelled to step forward as conspicuous supporters of public charity and benevolent caretakers of the city's expanding poor and refugee population. ${ }^{341}$

Such a major step into the public spotlight of mass charity was infinitely more palatable to Richmond's ladies during the war than it had been before. Due to the war's widespread, destructive influence on men, women, and children from all backgrounds, and due to the honor and patriotism associated with sacrificing a husband, son, or father to the war effort, impoverished women and children no longer stood out as social "deviants" or lazy do-nothings. The war's transformation of these sacrificing individuals into noble sufferers likewise transformed the South's definition of the "worthy poor."342 Suddenly, soldiers, bereft widows, and soldiers' wives deserved a second look from the government and from wealthy potential

\footnotetext{
340 Richmond Examiner, December 31, 1861.

341 Genovese, 76, 82; Faust, Mothers of Invention, 88, 24-6.

342 McCurry, Confederate Reckoning, 167, 169-70, 360, 216-217; Elna Green, This Business of Relief: Confronting Poverty in a Southern City, 1740-1940 (Athens: University of Georgia Press, 2003), 68, 83-4, 78; Minton, 337-338; Richmond Daily Dispatch, October 23, 1863.
} 
donors. Charity on behalf of truly suffering women and children, as well as soldiers, no longer seemed a burdensome obligation, but rather a patriotic and social duty. The only question left for Richmond ladies was how to establish themselves as champions of public charity without jeopardizing their cherished claims to respectable ladyship. ${ }^{343}$

As showcased by Mary Chesnut's interpretation of a lady's rights and responsibilities when engaging in charitable acts, many women of the capital elite chose to perform their charity at public venues or events where their fragile sensibilities might be spared of the brutal, sickening realities of war, but at which they still might contribute to the Confederate cause and to the health of society in a conspicuous and dignified way. Early in the war, neither men nor women considered "intimate" nursing appropriate for any respectable woman, let alone one of the upper class. Bathing naked men, touching blood and gunshot wounds, and assisting with amputations was simply considered "not done" during the Victorian era. However, as the war dragged on and necessity demanded the aid of the thousands of women left at home, society gradually came to accept and, in fact, encourage the employment of women-from all classesin the nursing profession.

As First Lady of the Confederacy, Varina Davis, like Mary Chesnut, initially attempted to offer some of her nursing skills in the city hospitals. Her peers expected Varina's frequent presence at the hospitals as part of her patriotic duty to the country and her benevolent duty to the "sons of the South." Varina herself also felt a conscious duty to help relieve the immense suffering of both Confederate soldiers and, interestingly, Federal prisoners of war that the conflict had produced. However, Varina's inability to deal with the horrific odors of hospital

343 Jennifer Lynn Gross, “'And for the Widow and the Orphan': Confederate Widows, Poverty, and Public Assistance," in eds. Lesley J. Gordon and John C. Inscoe, Inside the Confederate Nation: Essays in Honor of Emory M. Thomas, (Baton Rouge: Louisiana State University Press, 2005), 215-219. 
work, combined with her husband's instructions that the hospital, with its blood and death and scantily clad ailing men, was no place for the Confederacy's First Lady, resulted in the cessation of her nursing trips in 1862. Immediately, both men and women in Richmond and throughout the South began attacking Varina for abnegating her charitable duties, while some particularly vitriolic critics even went so far as to hold up Varina's lack of hospital work as further evidence that she never truly supported the Confederate cause, and even actively work to undermine the Confederate war effort. ${ }^{344}$

In efforts both to combat such rumors and to fulfill what she viewed as her vital role as caretaker of middling and lower-class women's soldier husbands, Varina took frequent carriage rides to the hospitals during which she sought to re-gain some of the critical public's respect by conspicuously donating large portions of food from her personal kitchen to the recuperating soldiers. ${ }^{345}$ No doubt Varina attained her own sense of personal fulfillment from such trips and from being able to actively help the Confederate cause. However, she hoped that the symbolic meaning of her hospital deliveries might bolster her image, and thus her success as the new First Lady. In taking the elegant Presidential carriage, drawn by two beautiful bay horses, to the hospitals while dressed in distinguished, but not overly flashy finery, Varina made a conscious effort to publicly reaffirm her social authority as the Confederacy's leading lady and as the chief model of feminine respectability. Varina's lack of flashy dress and her doling out of personal foodstuffs to the husbands, fathers, brothers, and sons of those women over whom she reigned served as a symbolic gesture of the non-aristocratic patronage that southern women expected,

\footnotetext{
344 Cashin, 134; 125, 128.

${ }^{345}$ Emma Bryan, “Reminiscences," Early Family Papers, Virginia Historical Society, (Richmond, VA); Cashin, 134
} 
and in fact demanded, of her. ${ }^{346}$

Many of Varina's peers engaged in similar public performances of charity at the city hospitals. Constance Cary noted that the owners of the "famous old wine cellars of private houses" put on quite a display with their repeated deliveries of "priceless Madeira, Port, sherry, and brandy" to the hospitals. These wealthy Richmonders also often ordered their cooks "to turn out dainties" for the sick and wounded which the woman of the house drove to the hospitals in a fine carriage for conspicuous distribution to the patients therein. ${ }^{347}$ LaSalle Corbell Pickett regularly appeared at the Richmond depot, cheering the arrival of the sick and wounded with a large basket of home-cooked food on her arm. ${ }^{348}$ (Interestingly, Pickett claims that she also was one of the few women who gained access to Libby Prison, the infamous place of incarceration for Union officers made prisoners of war. Appalled by the "scenes of indescribable wretchedness" at the prison by 1864, Pickett supposedly brought linen, eggs, biscuits, and fruit to some of the "more unfortunate" inmates. Her accounts of such visits are heavily tinged by Lost Cause nostalgia, however, and thus might be more the fictionalized byproduct of post-war memory than a record of true events). ${ }^{349}$

As "ladies in training," the young daughters from some of Richmond's wealthiest families, such as Emma Mordecai, followed their elders' lead in ritually promenading down the city's busiest streets and driving up to the city batteries in their fine carriages to deliver buttermilk, sweet milk, and other refreshments to Richmond's defending officers and the wounded in the city hospitals. Unable to long endure the sights and smells of the hospitals

346 Bryan, "Reminiscences."

347 Harrison, 82-83, 185; DeLeon, 149.

348 Pickett, What Happened to Me, 139;

349 Pickett, What Happened to Me, 152-4; 
themselves, and hesitant about pitching themselves into "unladylike" work inside the hospitals wards, Emma Mordecai and her young peers most often made quick work of their deliveries. Lauded for their charitable and patriotic efforts, as well as for their unique ability to procure special delicacies for the men which more common women could not afford, the young ladies remained just long enough to disperse their treats of lemonade, ice cream, and liquor to the soldiers. These brief trips to the hospitals and the city batteries quickly became as much of an ingrained ritual and social performance as the young ladies' parties, balls, dinners, and other ostentatious gatherings of the female elite. ${ }^{350}$

Clara Minor Lynn, a refugee from the Shenandoah Valley who lived in Richmond during much of the war, recalled one particularly benevolence-filled Sunday in 1862 when her minister instructed the congregation to return home and collect supplies for the soldiers camping outside of Richmond. Lynn recounted seeing distinguished "ladies in their Sunday best" moving busily through the streets, "all bearing with absorbing anxiety, dishes, trays, pans and buckets." Lynn supposed that Richmond "went dinnerless that day" as "strings of girls, children, and negroes carrying trays of corn pones, buckets of sorghum or vinegar and water- 'Confederate lemonade" filed down to the depot to deliver their goods. ${ }^{351}$ Undeniably, Lynn's memoir bears the stain of post-war nostalgia. However, even if the number of girls and ladies who responded to the minister's call that Sunday in 1862 was not as prolific, nor their sacrifices quite as extreme as she states or remembers, it is more than likely—and therefore significant—-that several of these wealthy women responded to the minister's pleas.

\footnotetext{
350 Emma Mordecai, entries dated May 13-26, 1864, June 16, 1864, Emma Mordecai Diary, Virginia Historical Society (Richmond, VA).

351 Clara Minor Lynn, “Reminiscences,” box 2, Southern Women's Collection, Eleanor S. Brockenbrough Library, Museum of the Confederacy (Richmond, VA).
} 
Likewise, Judith McGuire, Margaret Louborough, and young, well-to-do Florida refugee, Fannie Beers observed in their diaries that, from the beginning of the war to the end, ladies and their children and servants could be seen flooding the thoroughfares, delivering baskets, dishes, and trays full of meat, vegetables, and bread to the wounded and ill soldiers scattered throughout the warehouses and public buildings within the city. The ladies' participation in this ritual "promenade" of sorts enabled them to show solidarity with the poor and the widowed, while their public donations of finer food and beverages, often with their children and servants by their side, also allowed them to showcase their social prestige. ${ }^{352}$ Similarly, McGuire wrote that, by the end of the war, some ladies even publicly offered pieces of jewelry, elegant dinnerware, and even portions of their long hair for sale to merchants and blockade runners who exchanged such items for bread and other necessities for the wounded and for the destitute. ${ }^{353}$

The ladies hoped that such conspicuous practices of patronage and communal sacrifice might help to ease some of the class tensions caused by war by helping to bridge the social gap between members of the high and low classes. Additionally, the women believed that such acts might affirm the legitimacy of the capital elite's moral authority over society. Thus, Richmond's leading ladies relied upon these dramaturgical acts of charity to help provide critical stability for Richmond's social order while maintaining the privilege of engaging in more refined, "inoffensive" charitable work outside the hospitals.

Despite their apparent preferences for alternative charity work, Richmond ladies did not

\footnotetext{
352 McGuire, 103; Fannie Beers, Memories: A Record of Personal Experience and Adventure During Four Years of Civil War (Philadelphia: J.B. Lippincott \& Company, 1891), 38-39, 42; Margaret Louborough, The Recollections of Margaret Cabell Brown Loughborough: A Southern Woman's Memories of Richmond, VA and Washington, D.C. in the Civil War, ed. James H. Johnston (New York: Hamilton Books, The Rowman and Littlefield Publishing Group, 2010), 75, 84; Pryor, 185.

353 McGuire, 340-341.
} 
completely disengage from grittier hospital work altogether. Many post-war memoirs are overflowing with accounts of selfless, patriotic ladies who unhesitatingly abandoned their former lives of luxury and privilege and sacrificed everything they had for the benefit of "the Cause." In fact, these rosy accounts often seem unable to gush enough about the generous acts of the leading ladies and the complete lack of pretension with which the ladies delved into charitable work at the hospitals and in sewing societies, side-by-side with the destitute women of their city. ${ }^{354}$

However, a closer analysis of these accounts reveals the strong influence of the nostalgia that dominated the era in which such memoirs were written. In fact, some of these accounts occur within the same memoirs-if not the same chapters—as conflicting accounts that lament the selfishness and pretentiousness of Richmond's leading ladies who, they claimed, selfishly indulged in extravagant feasts, balls, and soirees until the fall of Richmond, much to the expense of the city's numerous charities. ${ }^{355}$ Doubtless, instances of both sacrifice and selfishness transpired throughout the war, and arguably many may have occurred congruently—an idea that will be explored in greater detail later in this chapter. However, upon comparing the rosier portions of certain memoirs with other accounts in those same memoirs and with contemporary accounts from newspapers, personal correspondence, and even hospital registers, it is evident that many of these written accounts have tended to exaggerate the numbers of elite women who truly immersed themselves in the "dirty work" of hospital life. Thus, we must carefully consider the memoirs through the discursive filter under which they were written.

Nevertheless, upon juxtaposing those memoirs with hospital records, newspaper reports,

\footnotetext{
354 Putnam, 39-40, McGuire, 178; DeLeon, 382.

355 Pember 59, 72, 77, 89; McGuire, 300, 302-3, 328; Magill, 328.
} 
and contemporary correspondence, a solid and reliable core of accounts of Richmond ladies' charitable work inside the city hospitals emerges. These accounts help to better enrich our understanding of elite women's varied perceptions of hospital work as a wartime adaptation of traditional southern ladyship, as a new kind of moral authority, and as a method of social organization. Several ladies and belles, such as Emily Mason, Phoebe Pember, Kate, Catherine, and Mary Rowland, Sally Tompkins, Juliet Hopkins, Maria Clopton, and even (on occasion) Constance Cary, Mrs. Roger Pryor, and Judith McGuire themselves spent long hours at the bedsides of the sick and wounded. ${ }^{356}$ Mary Randolph, wife of Secretary of War George Randolph, quickly assumed the overarching business of organizing relief for soldiers both in and stationed around the city with the creation of the Richmond Ladies' Aid Society. ${ }^{357}$

Distinguished 51-year-old Emily Mason, originally from Kentucky and Fairfax, Virginia, had been a "beautiful, accomplished belle of cultivated mind" prior to the war. However, upon leaving Fairfax in 1861, she left behind her "linen, books, china...household gold and goods...winter clothing, furs and silk dresses," and founded the earliest hospital in White Sulphur Springs, in present day West Virginia. After serving as a nurse in Charlottesville and Lynchburg, she worked as the Chief Matron of the $1^{\text {st }}$ Division of Camp Winder Hospital, a sprawling medical facility on the edge of downtown Richmond. ${ }^{358}$

Likewise, Catherine Rowland, the younger sister of Emily Mason, immediately pitched into nursing work with her daughter Kate as the matron of Richmond's Jackson Hospital.

\footnotetext{
356 Kate Pleasants Minor, "Richmond in the Sixties," box 2, Southern Women's Collection, Eleanor S. Brockenbrough Library, Museum of the Confederacy (Richmond, VA), 15; McGuire, 307; Kate Mason Rowland folders 1, 6, 7, box 1, Kate Mason Rowland Collection, Civilian and Home Front Collection, Eleanor S. Brockenbrough Library, Museum of the Confederacy (Richmond, VA).; Pryor, 185-6; Harrison, 381-9.

357 Pember, 3.

358 Kate Mason Rowland, "Sketches of Women: Miss Emily Virginia Mason," folder 6, box 1, Kate Mason Rowland Collection, Civilian and Home Front Collection, Eleanor S. Brockenbrough Library, Museum of the Confederacy (Richmond, VA).
} 
Catherine and Kate spent much of their time during the war passing from bed to bed, feeding and bathing the convalescents, dispensing medicine, reading the Bible to the wounded, and writing letters home to soldiers' loved ones. After performing her hospital duties, Kate frequently spent her evenings attending parties and balls at the houses of Richmond's most distinguished ladies and attending grand reviews of the Confederate troops at Camp Lee, on the city's outskirts. ${ }^{359}$ Kate was frequently joined by Miss Louisa Triplett, a "bud of Richmond," who helped her mother bake bread every week to take to the Robinson Hospital on $3^{\text {rd }}$ and Main Streets, and whose family sold their carriage to buy food for the other city hospitals. Forbidden by her father to dress in anything brought through the blockade, Triplett grew accustomed to helping nurse the wounded and the ill whom her mother received in one room of their family home during the afternoon, and then changing into her finer clothes to attend socials and dances in the evening with her friends. ${ }^{360}$

Juliet Hopkins, an illustrious refugee from Mobile, Alabama and wife of a notable Mobile judge, likewise eagerly helped city authorities transition several tobacco factories into city hospitals during the winter of 1861-1862. Hopkins worked tirelessly to solicit civilians for donations of food, medicines, and supplies for the hospital. ${ }^{361}$ Meanwhile, wealthy Virginia native and recent widow, Maria Clopton opened her own fashionable home at the corner of $4^{\text {th }}$ and Franklin Streets as a fully self-funded hospital in May of 1862. Clopton's hospital was so successful and so popular that it attracted the services of several of Richmond's belles, such as Constance Cary, who proved a frequent visitor. With one of the lowest mortality rates of any of Richmond's hospitals, the Clopton Hospital received the permission of the Confederate

359 Kate Mason, letter to "Jack," August 13, 1863, folder 11, box 1, Kate Mason Rowland Collection, Civilian and Home Front Collection, Eleanor S. Brockenbrough Library, Museum of the Confederacy (Richmond, VA).

360 DeLeon, 127.

361 Fergurson, 136. 
government to remain open throughout the duration of the war. ${ }^{362}$ Similarly, tidewater Virginia native Sally Louisa Tompkins also privately funded her own private hospital out of the home of Judge John Robertson, on $3^{\text {rd }}$ and Main streets. Born to upper-middle-class parents in Mathews County, the recently widowed Tompkins decided to use her family fortune to fund the illustrious Robertson Hospital, where survival rates were so high that the Confederate government ultimately granted Tompkins an honorary Captain's commission in the Confederate cavalry so that she could continue to run her hospital without any government interference throughout the duration of the war. ${ }^{363}$

Through their conspicuous work at some of Richmond's most popular hospitals, these ladies released themselves from the traditional expectations of southern ladyship and instead set about redefining Confederate ladyship through a variety of performative social statements about the necessary evolution of gender roles. Perhaps one of Richmond's most well-known, influential, and most expressive hospital matrons was distinguished, South Carolina-born Phoebe Pember, who worked at the sprawling Chimborazo Hospital on Church Hill. Pember's memoirs of her harrowing days at Chimborazo recount the immense struggles that she experienced in dealing with the other female nurses from various classes who were assigned to her wards. Her reflections provide fascinating insights into how the war-and particularly how its heightened demands for public charity--dramatically altered Pember's own perceptions of southern ladyship, social responsibility, and privilege. Although Pember's writings about her hospital work are far more detailed than those of many of her fellow matrons, the other matrons' dedication and loyalty to hands-on hospital work appears to imply that they, too, shared many of Pember's new-

362 Suella Clopton Blanton, "In Praise of Mint Juleps: Regarding The Honorable John Bacon Clopton \& His Wife Maria Gaitskell Foster," The Clopton Chronicles, Clopton Family Genealogical Society,

http://homepages.rootsweb.ancestry.com/ clopton/mint.htm (accessed 27 July, 2004).

363 Fergurson, 82-3. 
found perceptions of southern ladyship.

Even more importantly, Pember's memoirs offer a clear window into the ways in which Pember sought to alter the nature of both her own charity work and that of her fellow ladies (many of whom felt far more reticent about abandoning the traditional cultural prescriptions for southern ladyship), in order to showcase, what she perceived to be, ladies' newfound authority and social responsibilities as guardians of Richmond's wartime society. Pember and her fellow matrons partially succeeded in reshaping many of society's expectations of southern ladyship through their participation in unlikely charitable work. Upon realizing the hospitals' dire need for the nursing skills, organization, standards of hygiene, and "feminine touch" that only such women could provide, Pember's peers—as well as the press—-began to gush with praise and encouragement for Richmond's selfless sisters. ${ }^{364}$ Pember and her peers played a more direct role in both the physical and emotional support of many Richmonders and their ailing soldier relatives than did many of their more distant peers. In turn, through their "hands on" hospital work, these ladies unquestionably helped to earn the respect and appreciation of many members of the middling and lower classes, many of whose husbands, sons, and brothers benefited directly from the ladies' care. However, many upper-class women, such as those working directly under Pember, ultimately were simply unable to free themselves from the mental entrapment of traditional notions regarding gender and class.

Born to wealthy parents in Charleston, South Carolina, the widowed Pember moved to Marietta, Georgia to avoid the conflict when the war began. Discontented with life in Marietta, Pember began corresponding with Mary Randolph, who used her political connections to secure Pember a job as Chief Matron at Richmond's Chimborazo Hospital, which had opened up in

364 See, for example, Chesnut, 133; Cashin, 134; Rowland, 90-92, 113, 117; Davis, 203-4; Putnam, 40. 
October of 1861. Having already immersed herself entirely in relief and soldiers' aid work, Mrs. Randolph desperately needed what she called a "good woman's rule" in the hospital, as the surgeons and other, lower class nurses were apparently both frustrating and troublesome to supervise. Although she was concerned that a matron's career might be "injurious to the delicacies" of southern ladies, Mrs. Randolph assumed that, if she found the right matron, the moral and orderly benefits of a lady's rule would far outweigh any risks posed to her femininity. Pember, it seemed, would be just the right lady she needed. ${ }^{365}$

With beds for over 3,000 patients, and ultimately serving more than 75,000 soldiers during the course of the war, Chimborazo was considered a professional, truly state-of-the-art facility. When Pember reported for duty in December of 1862, she quickly realized that her former conceptions of southern ladyship no longer applied and that the harsh living conditions and emotional taxation of hospital life would completely eclipse her prior life of luxury. ${ }^{366}$ The thirty-nine year-old Pember carved out a small, semi-private residence for herself in the back of one of the one-hundred and fifty long, low, whitewashed hospital buildings atop Chimborazo Hill. Initially, Pember was shocked by and despaired over the roughness of her living conditions and the lack of any sort of comfort to which she had been accustomed. ${ }^{367}$ However, gradually she grew to tolerate, if not take solace in, her tiny "room" as a sanctuary from the horrors that she experienced out in the patients' wards. After proving herself a capable and serious worker to her fellow surgeons and the hospital administration, Pember graduated from housekeeper and cook to an active member of the nursing squad. Additionally, the Chief Surgeon, Dr. James Brown McCaw, entrusted her with guarding and equitably dispensing hospital luxuries, such as

365 Pember, 3.

366 Pember, 9 , xi.

367 Pember, 5. 
coffee, tea, and milk. ${ }^{368}$ Horrified by the greedy actions of several of the hospital's more underhanded surgeons who unhesitatingly helped themselves to shocking quantities of the precious supply of medicinal whiskey, Pember eventually also took it upon herself to guard the hospital's liquor under lock and key in her own quarters - a decision which resulted in several late-night confrontations with enraged surgeons. ${ }^{369}$

Pember's duties at Chimborazo ranged from bathing and bandaging the wounded, to feeding the sick, to writing letters home to soldiers' loved ones, even to personally deciding the fate of some of her patients during dire medical emergencies. ${ }^{370}$ She didn't shy away from assisting with the burials of some of her favorite patients, and occasionally even drove the burial wagon by herself to the local cemeteries. ${ }^{371}$ Additionally, Phoebe Pember assumed the role of ward "gate-keeper" as she desperately tried to prevent the families of the sick and wounded from swarming into the hospital, swamping the already tightly-packed wards, and demanding the attention and service of Pember and her nurses, who found themselves utterly overwhelmed by their patients alone. ${ }^{372}$

The confident and feisty Pember set a new example of southern ladyship for her female peers when she regularly flouted traditional gender conventions that championed compete female submission to their male counterparts. ${ }^{373}$ She frequently contradicted surgeons' orders when she felt they were insufficient and wasn't shy about insisting that her plan of treatment for particular patients was superior to that of the doctors, whose attention to any one patient was cursory at best. As a result, Pember often wound up in heated discussions with some of the doctors and

\footnotetext{
368 Pember, 8.

369 Pember, 11, 39.

370 Pember, 32.

371 Pember, 57.

372 Pember, 51.

373 Pember, 36, 43.
} 
hospital assistants when she dared to question their authority or deliver her own set of "orders" to them. When the angry surgeons demanded how she could consider herself a lady and yet be so headstrong and unsubmissive to men in authority, Pember fired back, "How could I, when brought into contact with such elements?",374

However as much as she flouted gender conventions, Pember slyly used her upper-class background and her "morally superior" femininity as justification for critiquing dishonorable manhood through her bold and brazen dealings with her male superiors and her shameless outing of supposedly "genteel" hospital doctors as selfish, lazy, and disrespectful ruffians. Additionally, Pember relied upon the rituals of hospital work and the social authority derived from her own claims to traditional ladyship to critique and re-craft former expectations of gender identity into more suitable and useful conceptions of ladyship during the Civil War. Ready and willing to sacrifice some (but not all) of the "showmanship" of ladyship for the more practical necessities of war, Pember - perhaps more than any other Richmond lady — was able to see beyond the blind spots of gender and class conventions to adapt to the demands of war while still preserving basic and empowering elements of her gender and class identity. Thus, in Pember, we are able to see one of the clearest examples of elite women's use and adaptation of a specific cultural identity and wartime ritual both to reclaim one's own moral and social authority and to fulfill an important new set of responsibilities to Richmond's floundering society.

One of the most fascinating performances of this revised southern ladyship, through which Pember attempted to train fellow ladies in her own image, restore moral order to the hospital, and still maintain social authority over some of her more fractious peers, occurred while Pember was overseeing the work of the ward nurses who labored under her. Shortly after the 
assumption of her new responsibilities at Chimborazo, Pember began looking for a set of nurses to help specifically with dispensing the medicinal liquor. Pember debated between choosing "ladies of education and position who I knew would be willing to aid me" and "the common class of respectable servants." Like Mrs. Randolph and other leaders of Richmond society whose conceptions of feminine duty and proper southern ladyship had evolved under the duress and new necessities of war-time living, Pember ultimately decided that it was a lady's moral responsibility to assume social leadership within the community and that only a lady would take her task seriously enough, as ladies (she assumed) would be "more amenable to authority.",375

Almost instantly, however, conflict erupted between Pember and her three charges. Pember's struggles with her new staff highlight the variances in opinion between southern ladies regarding their charitable duties and the proper performance of traditional prescriptions for elite female identity during the war. Upon receiving her directions from Pember, the first woman disappeared into the wards, only to return moments later with a look of disgust on her face. The woman reported that "she was a decent woman and 'was not going anywhere in a place where a man sat up on his bed in his shirt and the rest laughed...at her."' Realizing that the woman's "delicate sensibilities" would be incompatible with hospital work, the frustrated Pember immediately dismissed the woman, who never returned to Chimborazo. ${ }^{376}$ Clearly, some ladies clung much more fiercely to pre-war notions of respectability and the traditional "woman's sphere" than did other, more flexible women such as Phoebe herself.

The second woman, a petite, "light-haired and light-eyed and complexioned Englishwoman" arrived with seven large trunks which she unloaded at the feet of the concerned

\footnotetext{
375 Pember, 18.

376 Pember, 19.
} 
Chief Matron. Immediately expressing her displeasure at the thought of a lady being forced to walk around smelling liquor all day, the woman received her open pitcher of spiked hot punch "with nose turned, head high, held out with disdain," and huffed away into the ward. This woman, and the third member of the trio, at least performed their duties as assigned, despite their evident disagreement with Pember over their proper role as ladies in a hospital setting. ${ }^{377}$

However, later that day, the two new matrons came to see Pember, "Number two" serving as the spokeswoman of the duo. Number Two spoke "with a toss of her head," sniffed the air, and remarked drily to Pember that she seemed to have made herself "quite comfortable" in her private quarters, but that the other matrons were not so comfortable. The indignant woman declared that, as they, too, were ladies, they were just as "entitled to style" as Pember and they expected to be received in the same way as their Chief Matron. Pember quietly acknowledged their upper-class status, but the woman continued with her complaints, saying they were offended that Pember had not invited them over to her quarters for their expected social visit. Again, Pember nodded and told them that she was glad to hear that they considered themselves respectable women and that she "hoped they would always act as ladies should." The offended woman paused, then demanded that Pember come to examine their quarters for herself and see how unfairly their Chief Matron was treating them. When Phoebe arrived that evening at their quarters, she found the so-called "ladies" sitting around a spittoon with a “friendly box of snuff, dipping!" Enraged by the women's unladylike and lazy behavior, Pember demanded that they reform themselves, but the women haughtily remarked that if Pember was not going to treat them as ladies, then why should they act like ladies? Pember could not seem to

\footnotetext{
377 Pember, 19.
} 
convince them that the government, and not she, was in charge of their accommodations. ${ }^{378}$

It is doubtful that these women came from quite the same privileged class as Pember. However, their behavior shows that they did in fact consider themselves ladies indeed, deserving of the rights and privileges of the title, regardless of the conditions at the hospital. Although they wanted to affiliate themselves with Pember's class stature, they also looked up to her as their personal caretaker whose social status demanded that she provide for the comfort and interests of her fellow southern sisters. However, they neither honored Pember's role as the kingpin of the lady matrons of the hospital nor learned, from her example, to set aside former expectations of luxury and share in the communal sensibility of sacrifice and suffering that dominated charitable hospital work. Instead, the women's mental entrapment in their prewar cultural identities prevented them from adapting successfully to the demands of war. Thus, they appear not to have shared the same sensibilities of adaptable benevolence and malleable ladyship that infused the charitable actions of Pember and many of her fellow lady nurses.

Much to Pember's shock, during the following day's walk through one of her wards, she noticed that eight to ten feet of one of the buildings had been hastily partitioned off over night and a plank partition erected that divided a makeshift new room from the rest of the ward. Upon investigating more closely, Pember turned the corner to find the indignant "Number Two" matron "firmly entrenched among her trunks....enthroned like Rome upon her seven hills." Even more shocking, as Pember scanned the room, she noticed many of her own furnishingsincluding a nice table and comfortable chair, "choice pieces of crockery—remnants of more luxurious times that had at one time adorned my shelves....disposed tastefully around, and the drinks issued by me for the patients were conveniently placed at her elbow." The woman's nose 378 Pember, 20. 
and cheeks were flushed with intemperance as she stared defiantly at Phoebe. Upon ordering the matron to help restore the quarters to its original condition, explaining that there simply was no room for such luxurious living spaces in the ward, Pember received no response from the matron and was forced to send for a carpenter to help tear down the walls. Ultimately, Pember required the assistance of several male staff members to come and haul the drunk woman away from the hospital in a wagon. ${ }^{379}$

“Number Two's” brazen acts of defiance illuminate some of this woman's personal views on ladies' roles as hospital matrons. According to Number Two, ladies belonged in hospitals only if their positions would enable them to continue to enjoy the familiar comforts and luxuries of upper-class living, and if their work enabled them publicly to reaffirm their high social standing before their now diversified community. In their minds, a lady had to be able to distinguish herself from the lowly classes of white and black female nurses who surrounded her at the hospital either by performing more dignified work or by being allowed to perpetuate a familiar lifestyle of ease and comfort. If hospital work did not include such opportunities, such employment could only be seen as inappropriate, at best, and socially dangerous, at worst.

Pember's reflections on her encounters with her three new matrons allow us to see not only how diversely fellow women from a similar social class interpreted their rights and responsibilities as both physical and social guardians of wartime Richmond; they also show how Pember herself, as a kingpin of these women, assumed the responsibility of defining who was or wasn't a proper embodiment of the new, true southern ladyhood during the war. By removing the troublesome matron from Chimborazo, Pember reaffirmed her own personal place as an arbiter of moral behavior, respectable ladyship, and social order during the war. Only those 
ladies who followed her redefined model of southern ladyship would be allowed to ascend to the role of a leading lady within the confines of the Confederacy's largest hospital.

Largely because of the perceived incongruence of feminine respectability and hospital work, many of Richmond's leading ladies, in following in the footsteps of "Number two," turned more toward the organization of charitable societies, concerts, and fairs as a way to publicly display their empathy and care for the community at large, while still showcasing their rights to elite privilege and clinging to the familiar entitlements of southern ladyship. One such popular organization was the Ladies' Defense Association, created in early April of 1862 by leading lady, Maria Clopton. As members of the association's elite board, Clopton and her fellow ladies, such as Mrs. Stephen Semmes, Mrs. Reverend Hoge, Mrs. Reverend Minnegerode, Mrs. Colonel Gorgas, and Mrs. General Cooper, served as the recruiters of metal donations for the creation of an additional, much-needed ironclad gunboat. ${ }^{380}$ With the fall of New Orleans and Forts Henry and Donelson in Tennessee earlier that year, and with the constant threat of a naval incursion up the James River by the ironclad USS Monitor, the ladies feared for the protection of the Confederate capital and thus declared themselves the female guardians of the city.

The ladies placed numerous advertisements in the city newspapers, posted bulletins around the city, and even recruited by word of mouth for donations of metal. Although they later solicited local gentlemen for larger donations of one thousand dollars or more, the ladies most heavily relied upon the charitable contributions of fellow women. ${ }^{381}$ "Everyone should exert themselves to collect," the LDA proclaimed. "We urge all and everyone to assist us and to encourage them in this good work." Through appeals to collective self-sacrifice, the women of

\footnotetext{
380 LGA Ladies Defense Association folder, box 2, Southern Women's Collection, Eleanor S. Brockenbrough Library, Museum of the Confederacy (Richmond, VA).

381 Richmond Daily Dispatch, April 21, 1862.
} 
the LDA attempted to unite women of all classes under the singular patriotic goal of protecting the capital, while at the same time underscoring their own social prowess and leadership skills in serving as the patriotic female protectors of the capital city. The ladies especially appealed to women of the upper classes for contributions, and often did so by highlighting the generous sacrifices of even the poorest citizens. One lady noted, "a poor widow came to offer the association a bell metal kettle which she had owned forty years. I trust we shall have many such examples of self-denial. Do not delay, but send the iron, lead, and brass as early as possible."”382

Although the ladies asked that the metals and money itself be sent to the Confederate Navy at Rocketts Landing or to the Tredegar Iron Works for processing and shipment down to the Gosport Navy Yard in Norfolk, they still served as the symbolic collectors and dispersers of charity for the sake of "the Cause." The ladies also solidified their standing as direct gatherers and dispensers of charity through their staging of an LDA Bazaar on the corner of $9^{\text {th }}$ and Broad streets which accepted donations of all kinds toward the construction of the new gunboat. ${ }^{383}$ The ladies opened the Bazaar on May 3, 1862 and solicited women—especially those of the upper classes - for toys, paintings, pictures, embroidery and needlework, statuary, ornaments, books, produce, and cash.

While the ladies often sold these donations for money to put toward the gunboat, they kept large items, such as the statuary, paintings, and other pieces of art that they ultimately incorporated into an amateur art gallery "for the entertainment of visitors." The LDA charged admission to the gallery that they then donated to the gunboat fund. Although the association accepted large-scale cash donations from Richmond gentlemen, and any items that less wealthy

\footnotetext{
382 Mrs. Mary Fitch, letter to Maria Clopton, May 3, 1862, box 2, Ladies Defense Association folder, Southern Women's Collection, Eleanor S. Brockenbrough Library, Museum of the Confederacy (Richmond, VA).

383 Richmond Daily Dispatch, May 3, 1862.
} 
women could afford to spare, the LDA again specifically sought the help of fellow ladies, with the LDA constitution explicitly stressing, "the work and contributions may be more peculiarly ours as women, we will give such ornaments of gold and of silver as are our private personal property." 384

The women of the LDA expressly viewed such donations for the added security of the city as the unique charge of Richmond's ladies - a charge that was considered both a duty and a privilege. With their actions, the ladies engaged in traditional acts of southern benevolence befitting their social class, while simultaneously further sanctifying their behaviors through political appeals to patriotism. Not only were the ladies politically supporting the Confederate war efforts of their men on the battlefield and in Congress, but they also were performing a patriotic act of conspicuous, contractual protectionism which, they believed, reaffirmed their leadership abilities and entitlement to public authority. By ultimately broadening their solicitations toward non-city-dwellers and to women of adjoining states, the ladies, however unwittingly, also engaged in an act of public performance that expanded their authority and symbolic leadership into other parts of the Confederacy — a performance that undoubtedly strengthened the respect and the loyalty of Richmond's lower and middling classes whom the LDA's actions ultimately helped to protect.

The LDA's Resolutions reflect both the dire need for the ladies' public and the selfperceptions of the LDA members that they, as the moral guardians of society, should be the direct collectors and distributors of such aid. The Resolutions stressed that such donations would undoubtedly contribute to a victory that was necessary in order "to receive God's blessings and give to our children [their] civil and religious liberty." If the ladies' peers did not give, they

${ }^{384}$ Richmond Daily Dispatch, May 3, 1862. 
cautioned, their entire society— but especially the ladies' claims to privilege and authority— would be lost, as they feared that "it should be our sad fate to become slaves.",385

The Resolutions also publicly reaffirmed the ladies' engagement in a shared sensibility of sacrifice and suffering with the city poor. As a January 20, 1865 edition of the Richmond Enquirer made clear, it was necessary that all of the Confederacy was in "as much earnestness as the army," and that all southerners - wealthy and poor — be in the "same boat and meant really and truly to share the same fate, and sink or swim together." "The cause of the country demanded, and has received, the services of all her citizens, and has taken the lives of very, very many," the paper went on, "and it has also stripped the land of all its provisions. Now let the cotton and tobacco, the gold and silver, and the negroes be devoted to the success of our cause; and the spirit that surrenders—not the things taken—will make our cause successful." ${ }^{386}$ The LDA's public contributions not only helped the physical cause of the Confederacy, but it also helped to forge a critical bond between upper class organizers and middling to lower class donors. Furthermore, the LDA ladies' highly conspicuous, charitable actions provided fellow Richmonders with a social model of honorable sacrifice that was intended to encourage everyone to redirect their efforts toward a positive good for all of society, rather than toward selfish, rowdy, or immoral behavior which might contribute to the already unraveling social fabric of the Confederate capital.

The LDA's efforts were impressive and remarkably successful. The association received a continuous supply of iron scrap, bells, silver plates, gold watches, jewelry, and hundreds of dollars worth of donations from wealthy women, as well as from widows and yeomen women

385 “Resolutions of the Ladies Defense Association, 1862," Maria G. Clopton Papers, Ladies Defense Association folder, box 2, Eleanor S. Brockenbrough Library, Museum of the Confederacy (Richmond, VA).

386 Richmond Enquirer, January 5, 1865. 
from all over Virginia, North Carolina, and Tennessee. ${ }^{387}$ Still, however, the largest contributions unsurprisingly came from the wealthy.

The ladies of the LDA and their wealthy donors certainly were concerned about their own safety as well as that of the Confederacy, and so their efforts with the association undoubtedly stemmed from an earnest desire to help the Confederate navy to stave off any potential attack upon the capital by the Union's gunboats. However, it is interesting to note that, by April, the LDA began publishing the names of all of its donors in the city papers. The association had received several letters suggesting that doing so would encourage others to donate, which leads to the speculation that the chief supporters of the LDA were fully aware that their charitable actions were also a performative, public display of their moral and social duties whose fulfillment was necessary for the upkeep of their reputations and moral authority. ${ }^{388}$

As the war dragged on, the popularity of publishing the names of charitable donors, as well as the size or value of their donations, appears to have increased. The city's most prominent newspapers, such as the Richmond Daily Dispatch regularly included a column submitted by members of the Ladies' Soldiers' Aid Society and the YMCA that featured the names and accomplishments of the month's donors both from within and outside the city. ${ }^{389}$ While the column was intended to recognize the generosity of all donors, rich and poor, and to encourage others to give as liberally as they had, it is difficult to dismiss the idea that such publication was also intended to increase the reputations both of the committee leaders themselves and of the top

\footnotetext{
387 Philip de Batisty Jones, “To Dispatch Editor," letter to Editor of the Richmond Daily Dispatch, April 23, 1862, Ladies Defense Association folder, box 2, Eleanor S. Brockenbrough Library, Museum of the Confederacy (Richmond, VA); Cornelia Berkeley, letter to Mrs. Clopton, Ladies Defense Association folder, box 2, Eleanor S. Brockenbrough Library, Museum of the Confederacy (Richmond, VA); Louborough, 75.

388 Philip de Batisty Jones, “To Dispatch Editor," letter to Editor of the Richmond Daily Dispatch, April 23, 1862, Ladies Defense Association folder, box 2, Eleanor S. Brockenbrough Library, Museum of the Confederacy (Richmond, VA); Cornelia Berkeley, letter to Mrs. Clopton, Ladies Defense Association folder, box 2, Eleanor S. Brockenbrough Library, Museum of the Confederacy (Richmond, VA); Louborough, 75.

389 Richmond Daily Dispatch, November 4, 1863.
} 
donors.

For instance, on March 31, 1863, a Mrs. R.M. Grinnell of the Globe Hospital, took out her own partial column to publicly acknowledge the generosity of several prominent individuals who had contributed to the relief of the victims of the March 13 Brown's Island laboratory explosion. Grinnell's acknowledgments published both the names and contributions of each donor, chief among whom (interestingly) was the young belle, Miss Mary Pegram. ${ }^{390}$ It is important to note that, while Mrs. Grinnell's acknowledgments helped to publicly recognize and thank each donor, they simultaneously lauded her own personal efforts as the chief organizer for such relief. Thus, these columns and the frequent, pleading but also self-congratulatory newspaper reports from the ladies of the Union Benevolent Society and other major charitable organizations most likely served multiple purposes---to recognize and praise individual acts of charity and to inspire a competitive edge for such recognition that could serve both a practical and a social goal. ${ }^{391}$ A November 2, 1861 piece in the Dispatch hinted at this possibility, stating that "by informing one vicinity of what others were doing or had done, and by giving publication to all contributions made," it would increase what the writer considered the "laudable spirit of rivalry in public charity" for those who operated out of non-disinterested benevolence. ${ }^{392}$

Finished in June of 1863, the CSS Richmond joined the James River Squadron as a testament to the hard work and charity of Virginians and their friends from neighboring states; however, it also sailed as a conspicuous celebration of the leadership of Richmond's leading ladies who had stepped forward into the spotlight as guardians of the city through their rallying

390 Richmond Daily Dispatch, April 1, 1863.

391 Richmond Daily Dispatch, November 14, 1861.

392 Richmond Daily Dispatch, November 2, 1861. 
of the public behind "the cause" and through their own, "selfless," charitable donations. ${ }^{393}$ The praise that the LDA received from the press, both on the day of the Richmond's maiden voyage and throughout their years of charitable work, combined with the significant donations of money, artwork, food, and supplies that they received from women of all social classes, appears to have confirmed the success of the organization. Not only had the ladies of the LDA proven themselves to be caring and empathetic leaders of society, but they had also proven that they had the ability to lead successfully and help ease some of the material sufferings and wartime fears of society.

Richmond ladies continued to engage in "conspicuous charity" by organizing other fairs, concerts, and fundraisers in support of not only their soldiers, but also for their widowed, orphaned, and destitute sisters. During the war, some of Richmond's most distinguished women continued to fund the operation of the Female Humane Asylum, especially during the winter of 1862-1863 when the Asylum began receiving refugee schoolgirls and orphans from embattled Fredericksburg. Ladies increased their direct donations significantly, but also helped to coorganize a series of public fairs and benefits with the young ladies of the Asylum to help feed and shelter the new arrivals. ${ }^{394}$

Charity balls and benefits were quite popular among the capital elite, largely because they enabled the leading ladies to fulfill their charitable responsibilities while simultaneously enjoying the privileges of social prestige. Such events also allowed the ladies to symbolically engage with members of the lower classes by donating their event "admission" to charity, yet

\footnotetext{
393 Richmond Examiner, June 30, 1863.

${ }^{394}$ Account book of the Memorial Foundation for Children, December 1858-December 1867, Library of Virginia (Richmond, VA); Putnam, 201; Richmond Whig, March 30, 1865.
} 
still retaining a proper social distance from those lower classes. ${ }^{395}$ The Richmond newspapers overflow with stories of charitable theatricals, dances, dinners, and benefit concerts. ${ }^{396}$ While the local YMCA, several of the city churches, performance venues, and even various army regiments and brigades sometimes hosted some of these events, Richmond's ladies took charge of organizing a majority of the fundraisers. Women stepped forward both individually and collectively in church groups, the Ladies Benevolent Society, and the Ladies' Soldiers' Aid Society to lead fairs and bazaars to benefit the city's orphans, refugees, and destitute soldiers' wives. $^{397}$

Similar to the ways in which the women of the LDA conspicuously placed themselves at the head of the receiving line for donations to the ladies' gunboat and the LDA bazaar, the organizers of these other events made themselves the prominent and only direct collectors and distributors of the attendees' donations. By single-handedly assuming control of both the charitable event itself and the funds raised by the event, the ladies once again exhibited their willingness to care for their social inferiors in exchange for the loyalty and trust of those who required their care. Additionally, while women of all classes attended the fairs, Richmond's ladies clearly contributed the most to the events' monetary success, thus showcasing their own empathy for the lower classes while supporting a cause that was championed by their well-to-do peers.

Even more illuminating than their organization of the fairs and bazaars were the great

\footnotetext{
395 Rable, 140, 141.

396 Richmond Examiner, January 11, 1862, March 27, 1862, July 4, 1862, April 6, 1863, October 19, 1863, October 22, 1863, December 10, 1863, December 18, 1863, February 29, 1864, March 14, 1864, April 2, 1864, April 7, 1864, May 25, 1864, September 7, 1864, September 13, 1864, November 4, 1864, November 26, 1864; Richmond Whig, March 30, 1865; Richmond Daily Dispatch, October 17, 1861,December 24, 1861, January 14, 1862, January 23, 1862, March 14, 1863, June $27,1863$.

397 Richmond Daily Dispatch, October 14, 1863; Ellen Mordecai, letter to Alfred Mordecai, June 6, 1861, Alfred Mordecai Papers, Library of Congress (Washington, D.C.); Richmond Whig, March 30, 1865.
} 
efforts that Richmond's ladies exerted in arranging grand concerts, balls, and other entertainments whose public impact reached even farther and deeper into Richmond society. The ladies recruited vocalists, dancers, musicians, and orators from all over the country — and occasionally from overseas - to come and give a benefit for the needy families of Richmond. The ladies carefully selected these performers from the most respectable and famous class of entertainers, which included the world-renowned vocalist, Madame Ruhl, actresses Sallie Partington and Laura Keene, numerous Shakespearean performance troupes, and the most highly regarded of Richmond's own performers and speakers, including the Monumental Church choir, Reverends Moses Hoge and Charles Minnegerode, and various local brass bands and quartets. The ladies convinced the owners of Richmond's major venues, such as the New Richmond Theatre, Metropolitan Hall, the Mechanic's Hall, the Varieties, St. Paul's Church, the African Baptist Church, and even the large, spacious homes owned by the city's wealthiest residents to donate their spaces for the events. The city newspapers regularly advertised such events and strongly encouraged all Richmonders to attend. The fundraisers held in most of the public buildings were open to all classes of Richmonders who, for varying prices, could pay for different tiers of seating. ${ }^{398}$

However, the ladies' choice of entertainers and venues is particularly interesting because the ladies specifically chose performers from their own class, as well as entertainment that clearly represented the interests of the capital elite. In other words, the upper-class female organizers of such charity performances were, in making their selections for the entertainers, themselves imposing their own class interests upon society. By selecting from the very best

\footnotetext{
398 For examples, see, Richmond Examiner, October 22, 1863, January 11, 1862, March 27, 1862, July 4, 1862, April 6, 1863, October 19, 1863, October 22, 1863, December 10, 1863, December 18, 1863, February 29, 1864, March 14, 1864, April 2, 1864, April 7, 1864, May 25, 1864, September 7, 1864, September 13, 1864, November 4, 1864, November 26, 1864; Richmond Whig, March 30, 1865; Richmond Daily Dispatch, October 17, 1861,December 24, 1861, January 14, 1862, January 23, 1862, March 14, 1863, June 27, 1863.
} 
class of performers, the ladies thus showcased their own social privilege and the status quo for elite entertainment. By encouraging performances that celebrated intellectualism, moral living, and respectability, the elite organizers helped to provide a moral education for middling and lower-class attendees that might, in turn, inspire them to reform some of their own questionable, potentially threatening, and de-stabilizing behavior into that which more closely resembled the behaviors of Richmond's more upstanding social classes. ${ }^{399}$

However, the ladies used such demonstrations simultaneously to remind lower-class attendees of the class gap between themselves and their elite hosts. This gap would have been emphasized further by the difference in appearance between the elite organizers and the highclass attendees on the one hand, and the middling to lower-class attendees, on the other. The formality of the event demanded that the ladies wear their finer (though not overly flashy) clothes and fancy accessories - apparel which lower-class attendees' calico and pure homespun, no matter how nice, could never match. ${ }^{400}$

Additionally, the fact that the general public would be admitted into such a high-class entertainment, and seated near—but distinctly separate from—members of the capital elite, dually re-emphasized the gap between the classes (and thus the social authority of the elite) while allowing Richmond's leading ladies to project a sense of solidarity with the lower classes through shared sacrifice and support for the needy. Richmonders' excitement to be able to enjoy elite entertainment for reasonable prices, all in the name of a good cause, was evident through the newspapers' descriptions of packed venues of diverse audiences time and again throughout the war. Thus, these events, which fostered both the dramatic differentiation between the classes

\footnotetext{
399 Rable, 140-141.

400 Richmond Daily Dispatch, October 26, 1861.
} 
and yet, a sense of inter-class solidarity appear to have been quite popular to both elite and lowly members of Richmond society and perhaps, at least temporarily, helped to nurture peace and order in the capital city. ${ }^{401}$

The ladies' other, more exclusive charity balls, dances, and dinners at the Mechanic's Institute, Military Hall, and at their peers' residences enabled the women of the capital elite to engage in yet another useful performance of charity. These events almost always occurred in official buildings that bordered or were within a short walk of Capital Square, or in the homes of the high-ranking residents of Franklin and Grace Street or the elite Court End neighborhood. Such events also were almost always publicized — often quite heavily — within the city newspapers, and the news of their occurrence surely disseminated by word of mouth as well. ${ }^{402}$ Thus, these fancier charitable events allowed Richmond's ladies to showcase their benevolent concern for and their active protection of the lower classes, while conveniently allowing them to withdraw from some of the "riff-raff" that they might encounter at some of the more public charity events.

Here, at their private balls and dances, Richmond ladies could contribute a donation to the needy while conversing and dancing the night away in their finery, surrounded by other ladies and gentlemen of their own social class. Belles such as Constance Cary and Kate Mason Rowland often used such events as a chance to divert their anxieties and concerns over the course of the war and instead replace them with exciting flirtations with dashing men in

401 Rable, 140-1.

402 For examples, see, Richmond Examiner, March 27, 1862, November 20, 1862, November 16, 1863, December 10, 1863, December 18, 1863, February 29, 1864, November 4, 1864, December 29, 1864; January 4, 1865, March 13, 1865, March $30,1865$. 
uniform. ${ }^{403}$ These balls often were organized to raise money for an incoming tide of refugees, a recently widowed group of women, or for a particular army regiment. A ball given on March 26, 1863 at Military Hall for the benefit of the victims of the deadly March 13 explosion of the Confederate States Laboratory on Brown's Island (most of whom were young women and children) proved an especially popular event for Richmond's ladies. ${ }^{404}$

T.C. DeLeon also lauded the "many and excellent" amateur concerts that the ladies hosted for their peers to benefit the needy. Private concerts, charades, tableaux performances, and poetry recitations by visiting performers and even by some of Richmond's own leading ladies and gentlemen themselves at various churches, halls, and even homes along Grace and Franklin Street provided endless entertainment, diversion, and solidarity for the capital elite. The ladies hoped that news of such events might trickle down to the eyes and ears of the more soberminded members of the public and help to legitimize these frequent entertainments as hardly indulgent, but rather occurring merely for the sake of charity and the care for those less fortunate members of society. In several instances, they succeeded. ${ }^{405}$

As a careful observer of ladies' actions within the capital city, Sallie Putnam praised the numerous benefit concerts and tableaux that wealthy women continued to host throughout the war. However, at times she grew suspicious that such events were a mere cover for greedy individuals who would trick Richmonders into giving a "charitable donation" at the door that the hosts would ultimately use for their own selfish enjoyment. ${ }^{406}$ Thus, Richmond's ladies had to

\footnotetext{
403 Kate Mason, letter to “Jack," August 13, 1863, folder 11, box 1, Kate Mason Rowland Collection, Eleanor S. Brockenbrough Library, Museum of the Confederacy (Richmond, VA).

404 For example, see, Richmond Daily Dispatch, March 26, 1863; Richmond Examiner, October 24, 1863, November 13, 1863, November 21, 1864.

405 DeLeon, 63; Richmond Daily Dispatch, March 26, 1863; Richmond Examiner, October 24, 1863, November 13, 1863, November 21, 1864.

406 Putnam, 191.
} 
be continuously cognizant of the public's perceptions of their charitable entertainments as well as of the need to expressly separate their true performances of charity from the mock performances employed by the city's numerous scam artists.

T.C. DeLeon noted that Richmond's ladies went out of their way to broadcast the charitable intent of these gatherings, writing that, as "war and want" increased during the winter of 1862-1863, the ladies organized even more elaborate and attractive events in order to draw in more wealthy attendees who might better help to meet the increasing need for monetary assistance. The papers regularly reported on several of these exclusive events, often citing (and praising) the amount of money raised by the ladies for charity at such engagements. ${ }^{407}$ Ladies and their husbands poured into the musicales and charades receptions held at the prominent residences of the Carys, the Fishers, the Semmes, the Ives, the Webbs and the Macmurdos. In a particularly notable contribution to these fundraisers, Varina Davis donated a majority of her wardrobe to the performers and even volunteered her own acting talents upon occasion. The ladies held dress rehearsals in advance and painted lavish sets for the backdrop of the charades. ${ }^{408}$

While the capital elite enjoyed hosting regular non-charity charades and tableaux performances for their friends, many Richmonders lauded their dedication to producing so many elaborate private performances for the sake of charity. In fact T.C. DeLeon referred to one particular theatrical performance of "The Rivals" as "one of the greatest social successes of its time." Held at the home of Mr. and Mrs. Ives, "The Rivals" drew upon the contributions of wardrobe materials from all over society. Mrs. Ives and her peers recruited the best talent

\footnotetext{
407 Richmond Daily Dispatch, March 26, 1863; Richmond Examiner, October 22, 1863; see also, Richmond Examiner, November 25, 1863, January 11, 1864, January 16, 1864, November 21, 1864. 408 DeLeon, 217, 218; Harrison, 128.
} 
possible for the performance and transformed her stately parlor into an elegant mini-theater. Although some contemporaries and historians have scorned such elaborate events as selfish indulgences by the elite who merely used the guise of charity to justify holding a party for themselves, the funds raised during the performance of "The Rivals" and donated to soldiers and the needy can hardly be scoffed at. ${ }^{409}$

Doubtless, Richmond's ladies enjoyed the opportunity to dress up and gather together for some light-hearted entertainment (and the lavish dinners that always seemed to follow); ${ }^{410}$ however, their elaborate efforts and their donation of all of their proceeds to charitable causes demonstrated, again, an inter-class solidarity with those outside the sphere of the capital elite and sought to reaffirm the moral legitimacy of their power and influence over society. "The Rivals" and other, ensuing charitable charades performances featured dramatic performances by leading ladies Virginia Clay, Nannie Robinson, Hetty Cary, Constance Cary, Mattie Paul, and even Phoebe Pember, while grand hostesses Martha Standard, Mrs. Semmes, Mrs. Ives, and Mrs. Randolph offered up their houses for an evening of theatricals ${ }^{411}$. Dressed in their finest gowns and jewelry, Richmond's parlors were "crowded with the beauty and culture of the capital," and women such as Mary Chesnut, the Preston girls, and LaSalle Corbell Pickett dazzled Richmonders as they made their way over to their friends' homes atop fine carriages to take in an evening of entertainment for "the cause."

During these highly publicized, yet exclusively attended events, Richmond's leading ladies enjoyed the opportunity to fulfill their charitable responsibilities to society while

\footnotetext{
409 DeLeon, 224-227; Willie Pegram, letter to “Sister," February 11, 1864, Pegram-Johnson-McIntosh Papers, Virginia Historical Society (Richmond, VA); Rable, 192, 198-201; Faust, 244-5. 410 DeLeon, 223.

411 DeLeon, 197-245.

412 DeLeon, 224; Chesnut, 528.
} 
remaining among their "own" society. Their grand entrances and exits at the homes of the hostesses reaffirmed their social prestige, while their contributions to the fundraisers made such grand appearances permissible. Such charity receptions continued through the end of the war, with many short plays, charades, and tableaux offered during the winter of 1864-1865 featuring the talents of Millie Giles, Miss Mattie Paul, a Miss Conway, and Miss Constance Cary. ${ }^{413}$

Assuming a less flashy role in public charity, the "Richmond Mosaics," a group of wellto-do men and women who preferred to live more intellectually stimulating and more materially spare lives during the war, also contributed to the city charities. The Mosaics attracted the presence of distinguished local poets and authors, such as John Esten Cooke and John Thompson, an editor of the Southern Literary Messenger, the local Richmond Philharmonic and Richmond theatre companies, as well as amateur musicians such as the Macmurdo sisters, young Lucy Haxall, the Daniel sisters, Misses Evelyn, Mary, and Alice Vabell, Miss Nanie Robinson, and Annie Palmer. ${ }^{414}$

Gathering for both intellectual stimulation and for charitable purposes, the Mosaics met at various residences and at churches, such as St. Paul's and even the First African Church, where they freely donated their talents to charity. The group performed both at humble fundraisers hosted by their own members and at some of the more fashionable entertainments of their peers, who often sought their services as an "opening act" at their grand performances. ${ }^{415}$ Like their more ostentatious peers, the Mosaics encouraged a turn-out especially by the more "fashionable" crowd by creating special "deals" for the more respectable attendees, such as a two dollar ticket for one gentleman accompanied by two ladies, instead of the standard fare of one

413 DeLeon, 232.

414 DeLeon, 203-211.

415 DeLeon, 203-211; Richmond Examiner, September 27, 1861, October 14, 1861, September 13, 1861, October 18, 1861. 
dollar per individual. ${ }^{416}$ Clearly, the Mosaics desired a strong showing at their events from the more refined elements of society. However, their strict reliance on local, amateur talent and less ostentatious performances lent to their group a notable and impressive humility.

The Mosaics' personal humility, combined with their interest in doubly uplifting the community through charity concerts that also inspired intellectualism and artistic appreciation among all classes, added a unique and appealing, unassuming touch to many of the elite charity events hosted throughout the war. Admittedly, the group's notions of how best to assist the needy poor while not abandoning their elite social position differed from those of their more materially centered peers. However, the Mosaics and their independent charity events still provide an fascinating lens into how another sub-group of the upper class viewed charity as a simultaneous performance of social betterment for the poor and social differentiation for the elite - a performance that sought to stabilize society through a display of patronage from above and grateful approval from below.

And so, T.C. DeLeon remarked, "all the south was one great stage, from the opening overture at Sumter to the final curtain at Appomattox, men and women played in an endless tragedy, or in the comedics of statecraft....plays within plays" where "women with beauty and brains and a silvery tongue" could use their attributes to the advantage of themselves as well as society. To these elaborate performances of charity, DeLeon wrote, "stately dames of a dozen states came....the charity grub had fluttered into the society butterfly. Never was there a drama more earnest, actors more genuine, or resourceful....[for] even when the war was at the door of the rich, there were musicales, charades, tableaux, and dramas," greatly "applauded" by

${ }^{416}$ Richmond Examiner, September 25, 1861. 
Richmond society. ${ }^{417}$

The charitable ladies of Richmond did not always act alone. True to their traditional roles as supporters of the males upon whom they themselves relied for physical as well as social protection, the ladies frequently worked side-by-side with members of the War Department, high-ranking generals, and politicians, as well as ministers and the YMCA administration to help co-ordinate elaborate New Years feasts for the soldiers stationed in and around Richmond. However, in order to ensure the success of those feasts, the ladies were required to expand their public presence and influence beyond the traditional confines of the home and the local community. ${ }^{418}$ The ladies proved themselves quite willing and capable of such efforts, which made their charitable acts toward the soldiers even more impressive to greater Richmond society.

In a grandiose display of charity during the later part of the war, Richmond's ladies organized two elaborate feasts for the soldiers on New Year's Day in both 1864 and 1865. In late December of 1863, the ladies began taking up a collection for the feast in various churches and later, through the advertising help of the city newspapers, expanded the collection to Richmond society at large, and even to the House of Congress. The ladies worked in conjunction with Rev. Moses Hoge of the $2^{\text {nd }}$ Presbyterian Church, who, in turn, solicited the public for a collection to serve the hospitals lying on the eastern edge of the city. ${ }^{419}$ Likewise, in December of 1864 , the ladies joined together with a group of patriotic gentlemen from the city to form a committee to gather money and provisions for the 1865 soldiers' New Years' dinner. Once again, the committee advertised in the city newspapers as well as through a public proclamation to city-dwellers. On both occasions, the committee solicited aid from civilians of

417 DeLeon, 213-215.

418 Silber, 13, 41.

419 Richmond Daily Dispatch, December 29, 1863, January 1, 1864; Richmond Examiner, December 30, 1863. 
all social and economic backgrounds, and even begged those civilians living in the Virginia countryside surrounding Richmond to send in any extra supplies that they could spare to the city. The 1865 New Years contributions were so numerous that, even on January $4^{\text {th }}$, the Richmond Ambulance committee was still making its rounds to the various hospitals and camps to deliver the food. ${ }^{420}$

The capital elite's grand gestures of public charity, patriotism, and solidarity both with the Confederate army and with Richmond society once more re-centered the public's attention upon the enormity of their power as guardians of society as well as the unity that they felt with the "common sort" of society. The work of the ladies in soliciting women of all classes for contributions that they would then personally distribute to the husbands, fathers, and sons of those women was a critical component of their responsibilities in wartime. The ladies' hoped that their willingness and ability to organize such a large-scale charity dinner for the soldiers would help, once more, to solidify the legitimacy of their leadership and their roles as social and moral models in the eyes of their social inferiors, and thus secure the trust and loyalty of those whom they helped to serve.

A final example in which Richmond ladies' worldviews of their roles and responsibilities as societal leaders emerge clearly through large-scale, public rituals of sacrifice is their steadfast attendance in church on days of Fasting and Prayer. President Davis called for numerous fasting days throughout the short life of the Confederacy, often in response to military reverses or when disease and deprivation peaked in the crowded capital city. On these fast days, civilians spent a large portion of their day in church, listening either to ministers' sermons or to the cautionary words of Jefferson Davis about the need to repent for their sins and greed in order to win back

420 Richmond Daily Dispatch, December 23, 1864, December 29, 1864. 
God's favor for the Confederacy. Civilians likewise flocked to the churches on proclaimed days of thanksgiving where Davis and the city ministers advised them to thank God fervently for recent military successes and pray intensely for continued good fortune. Days of fasting and prayer, as well as large-scale religious revivals grew especially prevalent during the winter of 1863-1864, when the Confederacy entered into one of its darkest times, and continued on through the end of the war. ${ }^{421}$ Although we can not necessarily consider the ladies' attendance at the churches during these solemn days of prayer as an act of charity, the ladies' presence was certainly a performative showing of solidarity and empathy with the suffering poor, as well as with the soldiers. Richmonders expected their timely attendance at such events, and the ladies rarely failed to disappoint.

However, their comportment of themselves at such events was as equally as important as their mere presence. T.C. DeLeon noted that St. Paul's Church in particular, the popular, socalled "Church of the Confederacy" located just off of Capitol Square, stood out as the "church of fashion" to which women, dressed in their very finest Sunday dresses, would flock not only for flashy weddings and celebrations, but also for solemn services. Occasionally, Richmond's young belles used such solemn gatherings as a chance to flirt with the young gentlemen and officers in attendance. The attendees of St Paul's Church were so well dressed, in fact, that the church often was overflowing with the ranks of the middling and lower sort of society who desperately sought to catch a glimpse of some of the finery, if not share their Sunday worship with the city's elite. ${ }^{422}$

Kate Rowland, herself an establish young member of the Richmond elite, wrote giddily

\footnotetext{
421 Fergurson, 115, 193; Thomas, 130-32, 144.

422 DeLeon, 373.
} 
about attending service at St. Paul's, stating that sometimes she was scarcely able to concentrate on the minister's sermon due to the distracting personalities and fashions present at the service. After one Sunday service, in February of 1865, she noted, the "church was as usual crowded with the gay, the fashionable, and the tilted. Generals Lee and Longstreet [were] there with a host of lesser light. Lizzie and I agree, it is not well to go there often. Our attention is too much distracted to the contemplation of the fashions and the celebrities!"423

Clara Minor Lynn also reported that the ladies and young girls of Richmond used church gatherings as an opportunity to showcase their new bonnets, many of which the ladies had to fashion themselves as the war dragged on and the blockade impeded many of them from receiving new ones. Lynn remarked that the bonnet display was "a contagion" upon the congregation, "until rows of ladies might be seen sitting in a state of deep satisfaction under these ingenious and picturesque arborescences." Often dyed in all shades of colors and adorned with fancy feathers, lace, and flowers, the bonnets distinguished their elite wearers from the rest of the congregation, reminding all observers of the social prowess of these well-clad worshipers. Lynn wistfully noted that "to see the beauty of the village walk up the church aisle in such a hat, trimmed with what we all recognized as a strip purloined from her mother's damask curtains, did not provoke a smile unless of admiration and determination to go and do likewise. Each one was conscious of a similar triumph on her own person." ${ }^{, 424}$

True to its ever-critical form, the Southern Punch accused churches for too often assuming the airs and pretensions of public theaters where showmanship and personal display abounded. "Why are modern fashionable churches like theatres?" the Punch demanded. "They

423 Kate Rowland diary, entry for February 26, 1865, Kate Rowland Papers, Civilian and Home Front Collection, Eleanor S. Brockenbrough Library, Museum of the Confederacy (Richmond, VA), 146.

424 Clara Minor Lynn, “Reminiscences.” 
have a fine orchestra, fashionable dress circle and gallery, a practiced costumed reader in the pulpit who assumes dramatic postures and intimations and a door keeper in the shape of a sexton. ${ }^{, 425}$ The editors of the Punch were all too aware that, while the elite worshippers and fasters came to the church to sacrifice and pray in solidarity with their community for the good fortune of the Confederacy, they also did so with a keen eye toward reasserting their social privilege and flaunting specific models of high-toned respectability before the staring eyes of the general public.

Commitment to mass public performances of communal empathy, sacrifice, and charity had its limits, however. Although such performances clearly continued through the duration of the war, by 1863 especially, many upper-class Richmonders were beginning to question the motives and character of some of the city "poor." The military's transition into a phase of "hard war" resulted in the eviction of thousands more civilians from their homes who desperately sought refuge in the Confederate capital. The demands placed upon the city for food and shelter, combined with increasing government impressment of civilian goods and the growing tensions between destitute individuals, the upper classes, and the Confederate government produced some of the rowdiest and tensest moments in Richmond's history. Both frightened and disgusted by the actions of the "misbehaving poor," many of the capital elite began to withdraw from participation in mass public charity. Instead, Richmond's ladies began championing acts of more intimate and direct charity as both their true calling and as the measure of a "true" lady's moral, social, and political worth and authority.

425 Southern Punch, November 14, 1863. 


\section{Chapter 5-- The Perils of Compassion:}

\section{Public Disaffection and the Championing of Personal Charity}

On November 23, 1863, the Richmond Daily Dispatch released a pointed and notably hostile statement on the level of supposed "destitution" in the city in which it blatantly accused public beggars of greed and criminal intent, rather than of desperation. "Richmond is now infested," the paper proclaimed, and "her citizens annoyed, by scores of beggars from all quarters of the globe, and the police ought to be required to arrest and put them to work with as little delay as possible." Interestingly, the Dispatch expressly noted that most of these "creatures" were female, and often were foreigners with strange accents. "Prowling from street to street, they enter residences, without notice to the tenants, when the doors are open, and if not discovered, appropriate all valuables within their reach and decamp," the paper warned its readers. Describing the frequent pattern that these "wretches" seemed to follow during their burglaries, the paper noted, "if observed by a servant, they inquire for the lady of the house, and while the servant is gone to inform the mistress they exert their thieving propensities to the fullest extent. Some few days since one of these pests called at Dr. B. Burwell's residence, on 6th and Leigh, and in the absence of the servant appropriated two silver goblets to her own use." The editors saw no reason whatsoever for such theft, as both city authorities and Richmond's benevolent societies had seemingly "made the amplest arrangements for the care of the poor, thus rendering street begging unnecessary." Urging the city police to crack down on such brazen theft and prevent further injustices from occurring, the editors concluded, "the authorities should promptly arrest and punish the straggling paupers that now infest our streets." 426

The paper's sentiments reflected the feelings of many Richmonders - and particularly the

\footnotetext{
${ }^{426}$ Richmond Daily Dispatch, November 23, 1863.
} 
elite - that the city's generous support of mass public charity was being abused by individuals who feigned poverty and helplessness in order to feed their own greed and laziness. Such an idea deeply troubled the city elite, who feared that these greedy strangers had made a mockery of their benevolence. For many, this realization prompted a complete re-crafting of former charitable rituals into more guarded, individualized, and (hopefully) more effective distribution of personal aid.

The Dispatch was correct in stating that the city had authorized sizable amounts of monetary aid and provisions to be dispersed to the needy poor. Richmond's City Council minutes reveal that a sum of twenty thousand dollars had been appropriated to the Overseers of the Poor that year. ${ }^{427}$ Additionally, the reports of the Union Benevolent Society, the YMCA, and other large charitable organizations contain numerous accounts of large-scale food, fuel, clothing, and monetary donations to the poor. ${ }^{428}$ Such aid continued on until the end of the war, despite the city's desperate problems with inflation and shortages. In 1864, the city even boasted a Soup Association co-organized by Reverend Minnegerode, several Richmond gentlemen, and the ladies of the Union Benevolent Society, that dispensed free soup to the hungry with the aid of over nine-thousand subscriptions. ${ }^{429}$

However, it is entirely possible that even these sizable, official conduits of charity could not fully support the enormous needs of the swelling capital city by the late war period. Additionally, speculation, extortion, and scam ran rampant within the city as confidence men and women, eager to profit off of others' misery, greedily stole from the public coffers without

\footnotetext{
427 Minutes of the City Council of Richmond, Virginia, 1857-1866, April 9, 1863, vols. 14-15, Library of Virginia (Richmond, VA). 428 Thomas, $121-2$

${ }^{429}$ Richmond Whig, January 13, 1864; Minute Book of the Soup Association of Richmond, Eleanor S. Brockenbrough Library, Museum of the Confederacy (Richmond, VA).
} 
hesitation. ${ }^{430}$ Such intense pressures upon the large charitable organizations undoubtedly strained the city's meager resources and confounded wealthy citizens who could not understand how their sizable donations and charitable associations were not able to satiate Richmond's poor population. Thus, their frustrations with and suspicions over the constant demand for more mass charity that autumn are somewhat understandable.

However, for many former charitable donors, the tipping point for a reversal of mass public charity appears to have occurred more than six months earlier, during one of Richmond's most notable "civic wars" of the Civil War era. On April 2, 1863, over 300 women—many of whom were impoverished, but some of whom came from the middling to upper-middling classes - gathered in Capitol Square and proceeded to engage in a two-hour "Bread Riot" through the city's commercial district. With Mary Jackson, a 34 year-old market huckster, wife of a sign painter, and mother of a soldier at the head, the column of angry women stormed through the lower end of East Cary Street crying "bread or blood!" before turning up towards Main, Franklin, and Broad Streets to sack the stores of suspected speculators, government commissaries, and the old city market. ${ }^{431}$

The riot had been at least ten days in the making, with Jackson beginning to recruit her "rebels" from Richmond city, Hanover county, Henrico county, and New Kent county as early as March 22. ${ }^{432}$ The Richmond Bread Riot was one of twelve to occur that year throughout the South, with a very similar episode transpiring in Petersburg just the day before. Whether they occurred in Savannah, Mobile, Salisbury, North Carolina, Atlanta, Petersburg, or Richmond, the riots all bore the same characteristics: A largely female constituency, clear organization, the

\footnotetext{
430 Thomas, 118, 168.

431 For a full examination of the riot, see Chesson, pp 131-175.

432 Chesson, 139.
} 
threat of violence, and the use of the slogan, "bread or blood!"433 The evening before the Richmond riot, Jackson had organized her women at the Belvidere Hill Baptist Church, located in the predominantly working class neighborhood between Gamble's Hill and Oregon Hill. Assuming a rather masculine authority, Jackson ascended to the pulpit and instructed the women that, the next day, they would march in an orderly and respectable fashion to Governor Letcher's mansion and demand bread. If he refused, the women were to proceed into the heart of Richmond's business district and take it by force from the government commissaries and the shops of the suspected speculators. ${ }^{434}$

However, what is interesting about the "bread" rioters is that, as they approached the business district on April 2, they immediately began looting the stores of not just bread and meat, but also jewelry, shoes, silks, satins, brooms, and books! Many of the women dumped hundreds of pounds of flour and rice into the streets in protest, rather than carting it away to their homes, and the majority of the women refused to desist even when offered free rice by Col. William Munford and the YMCA. Ignoring the commands of Mayor Joseph Mayo and Governor Letcher, who read the official Riot Act to the women, and undaunted by the arrival of the heavily armed City Battalion, the women could only be stopped upon the arrival of President Davis himself and his order to the Battalion to fire upon the crowd if they did not disperse within five minutes. $^{435}$

Admittedly, the winter prior to the riot was particularly harsh, with nearly a foot of snow falling on Richmond during the last week of March. Additionally, a smallpox epidemic ran rampant through the city that winter, sickening thousands, and killing many. Tragedy also had

\footnotetext{
433 McCurry, Confederate Reckoning, 187-191; Chesson, 133-137.

434 Chesson, 139.

435 McCurry, Confederate Reckoning, 187-191.
} 
swept through the city when, on March $13^{\text {th }}$, a massive explosion at the Brown's Island gunpowder laboratory had killed and injured more than seventy of the laboratory's employeesmany of whom were young women and girls. ${ }^{436}$ Shortages, inflation, and speculation had also become such a problem in the capital that even the most basic of foods and clothing had become nearly unaffordable to most classes. Compounding the city's misery that winter and spring, the Confederate government significantly increased the amount of civilian produce that it impressed for use by the Confederate army, and the government completed its takeover of the rail system, declaring that the railroads running through Richmond would be for the transportation of troops and military items only. Richmonders were heartsick and enraged by what they perceived as the government's failed promise of protection and care during the war. Not only were the Confederacy's politicians apparently going to make life worse for the residents of the Confederate capital, but they also did not seem to care about the needs of their loyal constituents. Anger toward the government, speculators, hoarders, and the undeserving rich, combined with enormous frustration over the hardships presented by the recent winter, forced the rioters to take to the streets with passionate purpose. ${ }^{437}$

However, as is noted in the descriptions of the items that the rioters stole, that purpose was not merely to secure food with which to fill starving bellies. The rioters also appear to have been making a concerted political statement in which they indicted the government, the greedy, and the rich for not doing more to assist Richmond's commoners, and for failing to uphold their part of the social and political bargain in which they had promised to look after the commoners

\footnotetext{
436 Fergurson, 189.

437 McCurry, Confederate Reckoning, 187-191.
} 
in exchange for the commoners' loyalty, dedication, and sacrifice to the Confederacy. ${ }^{438}$

Although it only lasted two hours, the size, force, and destructiveness of the riot both unsettled and confounded Richmonders, especially the politicians and leading ladies, who had never thought that such a riot was even remotely possible. Within hours of the event, the city newspapers and several, appalled ladies began penning angry reflections on the riot, which, many of them believed, was entirely unnecessary and stirred up by the most degraded and selfish members of the society's lower echelons. ${ }^{439}$ In their reports, many of the newspaper editors sought to strip the rioters of their femininity and respectability (and thus entitlement to certain legal protections) altogether, referring to the women as "Amazons, viragoes, and termagants," and describing their looting actions in masculine, military terms such as their "impressment" of the goods and their filing through the streets of the business district in "platoons." 440 Lashing out at this violent and unfeminine display of selfishness, the Richmond Examiner termed the mob,

a handful of prostitutes, professional thieves, Irish and Yankee hags from all lands but our own....no doubt either, that they will be represented as "bread riots!" Bread riots! While this and every other city of the South has always had large appropriations for the poor; when labour is so scarce that everything in human shape that is willing to work can make from two to four dollars in the day; when seamstresses refuse two dollars and a half with board, because the said board does

\footnotetext{
438 McCurry, Confederate Reckoning, 187-191.

439 Interestingly, only a small set of Richmond's ladies appear to have discussed the riot in their diaries, memoirs, and correspondence, with most of those accounts constituting no more than a couple of pages of description and a few paragraphs of personal reflection or analysis. Considering the riot's enormous shock factor and impact on the psyche of the city, the ladies' silence on the event is somewhat mysterious. We do know that several of the leading ladies, such as Judith McGuire, Varina Davis, and Mary Chesnut, were away visiting family or temporarily residing in other locations during the time of the event, which perhaps explains some of the silences. However, a host of other ladies were still living in the Confederate capital during this event who apparently either did not feel the need to comment extensively-or at all-on the riots in their writings, or who may have done so in pieces of writing that were either destroyed or lost over the years. Perhaps the ladies were hesitant about leaving written records of an event that proved so embarrassing-and indeed, dangerous - to the Confederate capital. The ladies may have destroyed their writings about the event so as to prevent the potentially dangerous details of the riot from seeping out into the northern and foreign press during the war. Another theory is that the ladies may have destroyed such records in the postwar years in order better to promote the idea of a unified Confederate home front during the Lost Cause era.

440 Richmond Examiner, April 4, 1863; Richmond Whig, April 6, 1863; statement of Major John Daniel Richmond Daily Dispatch, December 30, 1888; statement of Dr. J.W. Anderson, Richmond Daily Dispatch, December 30, 1888; Davis, Memoir, 373.
} 
not include tea and butter! Plunder, theft, burglary and robbery, were the motives of these gangs of foreigners and Yankees the organizers of them. ${ }^{441}$

Equally as dismissive of the rioters and their supposed desperation, the Richmond Whig referred to them as "plump cheeked, well dressed women, courtesans and thieves and Mississippi wharf rats - people full of vice and profligacy, people who wage eternal war upon society and against which society must wage eternal war." ${ }^{, 42}$ During a session of the Mayor's Court, Mayor Mayo himself even went on record as saying that there was "no reason why there should have been any suffering among the poor of this city. More money has been appropriated than has been applied for. It should be, and is, well understood that the riot yesterday was not for bread. Boots are not bread, brooms are not bread, men's hats are not bread, and I have never heard of anybody eating them!"443

Likewise, Judith McGuire lambasted the rioters as members of "the very worst class of women and a great many who were not in want at all, which they proved by openly supplying themselves with jewelry and other finery." McGuire refused to believe that the mob represented the truly poor, and feared that the "true" poor suffered very much. ${ }^{444}$ Even young Emma Bryan labeled the rioters a "turgid mob with hoarse threats, the unwashed masses from the purlieus of the city.",445

With few exceptions, Richmond's ladies disparaged the rioters. However, one such exception was a woman known only as "Agnes," who was the wife of a colonel and friend of distinguished Sara Pryor. On April 2, Agnes was strolling the Capitol Square grounds when she was approached by what she described as a "pale, emaciated young woman." The woman

\footnotetext{
441 Richmond Examiner, April 4, 1863.

442 Richmond Whig, April 6, 1863.

443 Qtd. in Fergurson, 196.

444 McGuire, 202-3.

445 Bryan, "Reminiscences."
} 
informed Agnes that she and other women were gathering at the Square that morning to celebrate their "right to live." "We are starving," said the young girl, who told Agnes that she and her peers planned to march to the city's bakeries and "take one loaf each. That is little enough for the government to give us after it has taken all our men." The young girl raised her sleeve to reveal the bony outline of her arm and laughed, “that's all that's left of me. Pretty funny, isn't it?” Unaware of the violent intentions of the riot, Agnes wholeheartedly supported the girl, and wished her success in her endeavors. ${ }^{446}$

Following the riot, Agnes conveyed her deep sympathy for the young girl and her fellow rioters, writing to Sara Pryor that "something very sad has happened in Richmond." In a rare moment of written self-reflection about the terrible class iniquity that plagued wartime Richmond, Agnes wrote that the riot "makes me ashamed of all of my jeremiads over the losses of the petty comforts and conveniences of life." Agnes's correspondence illustrates that at least some middling women felt sympathy for the truly starving members of the rioting group. ${ }^{447}$

However, her surprising "moment of truth" in which she realized the pettiness and destructiveness of her own obsessions with "hats, bonnets, books, stationery, and dainty food" during such a desperate time separates her from most other women of her class. ${ }^{448}$ Indeed, even for young Treasury Department worker, Margaret Louborough, who came face to face with some of the rioters during her morning walk to work apparently felt no guilt or pause whatsoever. Rather, immediately following her description of the rioters, Louborough proceeded into a whining rant about her lack of clothes for an upcoming theatrical at Mrs. Ives's house! "I was in

\footnotetext{
446 John C. Waugh, Surviving the Confederacy: Rebellion, Ruin, and Recovery: Roger and Sara Pryor During the Civil War (New York: Harcourt, Inc., 2002), 184-6

447 Waugh, 184-6.

448Waugh, 184-6
} 
great straits for something to wear," she lamented, "as I had given my silk dresses for a war balloon, which I believe burst from the inequality of the various silks composing it." This "patriotic" young lady was desperate to find a replacement for the dresses that she had "so nobly" dedicated to the Confederate cause. Clearly feeling entitled to continue attending exclusive parties and gatherings, even in the wake of such a dramatic riot for food, Louborough continued to moan the fact that her "shoes were as good as could be bought, but were coarse and not fit for dancing." After writing to her grandmother for new ones, she instead received an "old brocade and wedding dress" with which she covered her old dancing slippers. Still not satisfied with her appearance, she proceeded down to Main Street to a "Jew's shop" filled with "shopworn goods," including yellowed lace, brown cloth stripes, and a "pretty sprig" out of which she fashioned a new dress for the party. Covering the dress with "lemon colored silk," Louborough sighed that she "would not insult a balloon" by donating such a rag tag dress to it; however, adorning herself in sparkling topaz jewelry, Louborough confessed that she felt "stunning, and my finery created a sensation." 449

Louborough's flippant response to the Bread Riot, combined with the frustrated and angry reports of the city's leading ladies, government officials, and newspapers editors reveal little societal sympathy for the rioters. Furthermore, these writings vehemently rejected the idea that there could be such a desperate need for increased charity. It is still unclear whether Richmonders were correct in making such assumptions, whether they were in abject denial over the seriousness of their situation, or whether they desperately needed a scapegoat to explain away the embarrassing and potentially politically dangerous riot. What is interesting, and quite telling about Richmonders' conceptions of forgiveness and social re-acceptance, is that, during

\footnotetext{
${ }^{449}$ Louborough, 75.
} 
the trials of the mere 41 women and 29 men arrested for their participation in the riot, those women who presented themselves as "pretty, handsomely dressed, respectable, contrite," and meek women were referred to as young "ladies" whom the court either acquitted or allowed to go on bail. Other, "rawboned, toothless, hags" either were fined, sent to the city jail, or, worst of all, removed to the Virginia Penitentiary. ${ }^{450}$ Apparently, not only Richmond's leading ladies, but also the law, protected those individuals who displayed a "true" remorse for their actions and exerted a notable effort toward joining (or rejoining) respectable society in the wake of their misguided actions by adhering to the social codes of ladyship. Perhaps with these young, misguided "ladies"” re-adherence to the prescriptions of ladyship and moral behavior and with their re-assimilation into the ranks of the respectable, the Richmond elite had gained a small, if not ironic, victory after all.

The full explanation of the riot also remains unclear. Were conditions merely deteriorating across the southern home front after two full years of war? Was the harsh winter of 1862-1863 simply too much to bear for Richmond's lower classes? Were Richmond's rioters angrier about inflation and speculation, and the government's inability to curb it, than they were hungry for bread? Were the rioting women upset that, while the upper classes of ladies still largely enjoyed the privileges of ladyship and respectability, they had been transformed into mere shells of their former selves? Perhaps we will never know the answers to such questions. However, we do know that, although the riots never re-occurred, they left a lasting impression on the way that some of Richmond's chief charity-givers perceived their social inferiors and the way they re-thought their relationship to those under their charge.

In perhaps one of the most interesting reflections on the riot, Sallie Putnam also accused

450 Chesson, 153-166. 
the rioters as being "a heterogeneous crowd of Dutch, Irish, free negroes, men, women and children" who committed one of the most "impudent and defiant robberies ever." Like McGuire, she readily admitted that it "could not be denied" that there was indeed a want of bread at the time, and insisted that the "sufferers for food were not to be found in this mob of vicious men and lawless viragoes....the disaffected in our midst ad our enemies from abroad" who sought to "misrepresent and exaggerate" the real condition of the Confederacy. However, in an unexpected change of tone, Putnam lashed out that the "real sufferers" were actually the "most worthy and highly cultivated of our citizens... who were compelled to seek [shelter] in the crowded city....How great their necessity must have been," Putnam writes, lamenting the plight of some of her fellow ladies who, "reared in the utmost ease, delicacy, and refinement were compelled to dispose of all articles of taste and former luxury and frequently necessary articles of clothing to meet the everyday demands of life."451 Instead of trying to empathize with the plight of the starving and the homeless, Putnam instead turned the spotlight on herself and the upper-classes of society whose removal from their former lives of luxury, she insisted, was far more traumatic than the sufferings of the lowly poor!

Although it is questionable as to whether Putnam's peers shared such exact sentiments, the fact that Putnam even bore them opens up a whole new perspective on how Richmond's ladies internalized the riot as a metaphorical slap in the face from some greedy members of the lower classes whom the capital elite strove to protect and serve. Such sentiments also provide background for the angst and inner fear which others clearly expressed through their own writings that dangerous outsiders, "foreigners," and prostitutes could masquerade in the form of "the worthy poor" during a "bread riot" and attempt to fool the capital elite out of their own

451 Putnam, 208-210. 
money and empathy. Such prospects were deeply unsettling to Richmonders who had never before experienced such a large riot, and by a group of women, no less.

It is no wonder, then, that within a week of the riot, the city government and aid associations decided upon a new filtering process in order to differentiate the truly worthy poor from the riotous pretenders. Although the City Council again appropriated another twenty thousand dollar sum to go toward the support of the poor, the Council declared that, from then on, a committee of twenty-four men from the various wards of the city would be charged with going door-to-door to decipher the true condition of each and every applicant for government rations, and that those whom the committee deemed members of the "worthy poor" would then receive a set number of tickets which they could exchange for rice at one of two supply depots. ${ }^{452}$ It is worth noting that the elite ladies of the Union Benevolent Society frequently assisted the committee with their visits. The ladies' presence, and their issuance of the tickets to receive free nourishment, serves as yet another clear demonstration of elite women's authority and of their attempts to re-delineate the social order of society based upon their own conceptions of individual moral worth.

Both the writings of the ladies themselves and the actions of the city government provide some insight into why some of Richmond's ladies viewed the outcries for more mass public charity with suspicion. The Richmond newspapers continued to call out the shameful acts of the "unworthy poor" throughout the rest of the war, while warning civilians against these “creatures"” manipulative actions. An August 1, 1864 article in the Richmond Daily Whig noted that "cripples and the blind, widows with children, and soldiers' wives need subsistence....but do

452 Minutes of the City Council of Richmond, Virginia, 1857-1866, April 9, 1863, vols. 14-15, Library of Virginia (Richmond, VA); Thomas, 122. 
not haunt the places where public charities are given out," nor were they "besieging the doors of benevolent citizens." The Whig acknowledged that Richmonders must assist the truly worthy poor, but warned that "the itinerant beggars at the Christian Association and the supply store... and benevolent houses, begging and whining, are not the very poor." In fact, the Whig explained, "they are not poor at all, but are seen in the market with free meat, corn, and tomatoes, and keep negroes to wait on them....some are profligates of the worst order, who spend the nights in vile debauchery and the days in begging." ${ }^{453}$ Likewise, a December 17, 1864 article from the same paper also scorned the women who "have spent days on the street begging, representing themselves and their children as starving" but who were "found out to be imposters by thumbing up their nose" at offers of free soup. ${ }^{454}$ With such concerns about mass public charity and unscrutinized private charity running rampant, it is no wonder that many of Richmond's leading ladies thus began engaging in more personal acts of charity.

As several historians such as Kenneth Greenberg, Eugene Genovese, and Bertram WyattBrown have noted, personal, face-to-face assistance had always been a defining hallmark of southern charity. ${ }^{455}$ As such, both prominent men and women believed it was their responsibility, and in fact, it was their preference, to help a friend, family member, or even family slave who was in need. Evidence of such intimate acts of charity abound from the antebellum era and throughout the war. Therefore, it is impossible, and indeed incorrect, to state that episodes of personal charity in Richmond only emerged in the wake of the traumatic Bread Riots or that they wholly replaced the practice of mass public charity which, as discussed previously, continued to occur.

453 Richmond Daily Dispatch, August 1, 1864.

454 Richmond Daily Dispatch, December 17, 1864.

455 Greenberg, 65-6, 70, 80-81, 84-5; Genovese, Roll, Jordan, Roll, 51, 58, 4, 110, 71, 74; Genovese, The Slaveholder's

Dilemma, 28-9; Wyatt-Brown, 55, 61, 124-5, 152; Fox-Genovese, 32. 
However, numerous instances of private charity did transpire, many of which occurred in late 1863 and later. In the fall of 1864, Mary Chesnut recounted a particular instance in which Varina Davis welcomed a shabbily dressed, unknown woman into her home who desperately sought the First Lady's help in procuring a pardon for her husband who had tried to desert from the Confederate army in an attempt to help his suffering family back at home. The woman, "chalk white and pinched in the face," related the story of how she had encouraged her husband to desert after the armies had passed near their home, taking the majority of their food. The family's daughter, Susie, had also recently died, the family slaves had all run away to Union lines, and the rest of the family was so weak and ill that they were unable to take care of themselves and their farm any longer. After her husband had deserted, he hesitantly rejoined the troops aboard a gunboat in the James River but was caught returning to duty by several officers who were now threatening to shoot him. According to Chesnut, the woman spoke good English and tried to make herself look respectable "in all her forlorn clothes, knots of ribbon, artificial flowers and draggled feathers in her old hat." Chesnut and the First Lady immediately felt sorry for the woman, and Chesnut remained with her in the parlor to comfort her while Varina disappeared to speak with her husband. Several minutes later, Varina returned with a pardon from the president that she presented to the poor woman, who ultimately collapsed onto a sofa pillow, sobbing with relief. ${ }^{456}$

Chesnut wrote that she was so touched by the woman's telling and re-telling of her plight that she "could never forget it." Clearly, both she and Varina Davis truly felt for the miserable woman. However, the language with which Chesnut described the incident is particularly interesting, as she noted that the woman pleaded with them by saying that she knew that "you are

\footnotetext{
456 Chesnut, 610-11.
} 
sorry for me." Chesnut responded that indeed she was, as she was a true "friend of the hard driven soldiers." Although we can hardly doubt that Chesnut's and Davis's reactions to the woman's story were anything but genuine, such language perfectly illustrates the contractual relationship between soldiers' wives, many of whom were members of the "worthy poor," and their female superiors who possessed both an authority over and a responsibility to their peers that was simultaneously social and political in its nature. This particular quote offers a unique insight into the worldview of needy women regarding the workings of social and political power and their expectations of the capital elite. Additionally, Chesnut's response to this woman allows a direct window into her own worldviews regarding her and Varina's practical and symbolic roles as members of that capital elite. ${ }^{457}$

The poor woman's expectations that Varina would help to assist her struggling family, due to her social and political affiliation with the worthy poor as a soldier's wife, combined with Chesnut's response that "of course" she would help such a woman, illustrate the power dynamics inherent in this personal exchange of charity. (Although, we must take into account that, in this particular instance, the woman in need was the white, apparently once wealthy, wife of a slaveholder - characteristics that certainly may have made her case more appealing to the slaveholding Mrs. Davis). Furthermore, they offer a tangible example of how each woman's role within society—one as the soldier's wife, the other as a social leader and protector—bound them together in the performance of a powerful social and cultural contract. Both classes of women relied upon that contract — the ensuing loyalty of the under-classes in exchange for the protection promised by the upper classes - in order to maintain the delicate equilibrium of societal relationships during the Civil War.

457 Chesnut, 610-11. 
Although Mary Chesnut tended to prefer more personalized charity over mass public charity, she was not always so willing to jump to the aid of a complete stranger who asked for her help. In August of 1861, an unthinking Mary Chesnut arrived at Sally Tompkins's famed "Robertson Hospital" on the corner of $3^{\text {rd }}$ and Main Streets to pay a brief visit to "any South Carolina men" who might be recovering there. Tompkins immediately snapped at her that there was no room for such selfish women as she at her hospital, as Tompkins and her nurses treated everyone equally and "never asked where the sick and wounded came from. ${ }^{, 458}$ Chesnut apparently was so focused on pre-war practices of local, more "familial" charity that she did not stop to think that her social and political roles had now expanded to a much more selfless cause which demanded a different, and much broader conception of personal charity, as well as a national, and not just merely state, allegiance. Again, in March of 1862, Chesnut balked when numerous, unfamiliar women and servants sent by other women appeared at her door, begging for her influence in procuring an officer's commission for their sons and husbands. These strangers' early pleas for assistance initially annoyed Chesnut greatly, who complained to her diary, "If I had the influence these foolish people attribute to me, why should I not help my own?....I shut the door in the servant's face....After a long talk we were finally disgusted and the women went off...”459

Thus, in the early part of the war, Chesnut seemed still unfamiliar with and even exasperated by the thought of extending personal charity to complete strangers. Chesnut's above-noted reactions to Varina Davis's late-war visitor, however, reveal a fascinating change in her personality and the acceptance of her role as a personal charity aide to friends and strangers

458 Chesnut, 133.

459 Mary Boykin Miller Chesnut, A Diary From Dixie, as Written by Mary Boykin Chesnut, Wife of James Chesnut, Jr., United States Senator from South Carolina, 1859-1861, and Afterward and aide to Jefferson Davis and a Brigadier-General in the Confederate Army (New York: D. Appleton and Company, 1905),145-6; see also, Chesnut, Mary Chesnut's Civil War, 138. 
alike in the city. That transition was not easy, however.

As Chesnut struggled to come to terms with her unique wartime duties, she vacillated between how best to display her necessary empathy with the under-classes while still retaining her dignity, composure, and proper social distance as an elite female. In December of 1863, a confounded Chesnut wrote that "today a poor woman threw herself on her husband's coffin and kissed it. She was weeping bitterly. So did I in sympathy." In her efforts to present herself as a sympathizing and benevolent figure to this woman and the small crowd of on-looking grievers, however, Chesnut flouted one of the major Victorian social rules about grieving in public. Chesnut's outburst, while showcasing an appropriate sadness for the loss of this individual's loved one, revealed a lack of emotional control which many — both men and women — viewed as inappropriate, and potentially not even genuine. ${ }^{460}$ Chesnut received the sharp rebuke of her husband, who growled, "noisy, figety grief never moves me at all. It annoys me... You think yourself a miracle of sensibility. Self control is what you need. That is all that separates you from those you look down upon as unfeeling." Stunned and hurt by her husband's accusations, Mary Chesnut sharply remarked that "he would see me and everything he loved hung, drawn, and quartered without moving a muscle if a crowd was looking on." ${ }^{, 461}$

Judith McGuire appears to have understood more clearly how properly to engage in personalized acts of charity. In 1864, McGuire described wandering the streets with some of her friends, their hearts "aching for the poor." On one of her walks, McGuire met a "wretchedly dressed woman of miserable appearance seeking the YMCA for assistance and work." Pitying the woman, McGuire and her friend carried her to the door of the YMCA but could not procure

\footnotetext{
460 Halttunen, 138-9; Chesnut, 500.
}

461 Chesnut, 500. 
her any new clothes, so they instead brought her back to McGuire's temporary home, where they gave her food, and told her to come see McGuire the next day. The woman returned and, with "honest countenance," related her miserable story to McGuire that her husband had been killed at Second Manassas and that she had been forced to flee from Fredericksburg to Richmond with her three children to look for shelter and a job. Unable to procure any work, the woman finally was befriended by a kind female who lent her a room and small garden patch; however, her residence stood outside the city limits, thus prohibiting her from receiving any relief from the city's poor-relief funds, and her job did not pay her nearly enough to support her family. McGuire graciously gave the woman a piece of meat and promised her that "her case should be known" and that she would not suffer again. McGuire asserted in her diary that "a soldier's widow shall not suffer from hunger in Richmond. It must not be and it will not be when her case is known. ${ }^{462}$ McGuire and her friends spread the story of the unfortunate woman through their social circle, gradually drumming up interest from several other ladies who were interested in her plight. Upon going to search for the woman later at the squalid Butcher Flats neighborhood located on the low ground east of the city's outskirts, McGuire could not find the woman, but hoped that she had managed to find a new home and an improved life in a better part of the city. ${ }^{463}$

McGuire's description of her encounter with the distressed woman again reveals elite women's perceptions of the legitimacy of soldiers' wives as the "worthy poor." Her account also highlights Richmond ladies' perceptions of their own duties in caring for the women who so dutifully sent their men off to fight for the Confederacy and so loyally supported the cause championed by the capital elite. Additionally, McGuire's diary entry showcases her attempts to

\footnotetext{
462 McGuire, 252-5.
}

463McGuire, 252-5. 
identify and distinguish worthy members of the lower classes from the unworthy members through the dispersal of charity. Her broadcasting of the poor woman's story to other ladies thereby illuminates her understanding of herself as a social and political crusader for the class of women known as "soldiers' wives" whom, she felt, required the constant care and sympathy of the upper classes. McGuire's personal acts of charity, in plain sight of the public and the poor community, stand out as a clear performance of elite identity, power, and patronage that would not have been lost upon her observers.

McGuire and her peers continued such acts of personal charity throughout the war, publicly assisting certain poor women with both their physical survival and their emotional comfort. ${ }^{464}$ As a leader in breaking down the physical barricades between the upper and lower classes during the later part of the war, McGuire often encountered numerous poor women on the streets who sought her help for all different reasons. In one particular instance, McGuire agreed to read a letter five times to a disheveled looking woman that was written by her soldier husband. "Very much interested" in the poor woman, McGuire and her friends made a special effort to comfort the woman, encouraged her to keep supporting her husband's efforts in fighting for the Confederacy, and celebrated his bravery and courage with her. In doing so, McGuire and her peers were simultaneously fulfilling their duties as caretakers of soldiers' wives while helping to solidify these poor women's loyalties to and trust in the Confederate nation, its leaders, and the society which ultimately supported and defended the privilege and power of its leading ladies. However conscious McGuire may have been of the larger, symbolic meaning behind her actions, she clearly was operating within an ingrained culture, set of worldviews, and understanding of social relationships that revolved around the simultaneous patronage and leadership of the capital

\footnotetext{
464 See also, Lizzie Munford, letter to "Mag," May/June, 1863, Munford/Ellis Papers, David M. Rubenstein Rare Book \& Manuscript, Duke University (Durham, NC).
} 
elite.

While performances of public charity by McGuire and her peers often spoke for themselves, Richmond's newspapers frequently lauded particular women for their dedication to personal charity. Richmond's papers are filled both with vignettes and obituaries that describe, in depth, the gracious and selfless acts of both Richmond's and greater Virginia's ladies. ${ }^{465}$ In one particularly interesting article, the August 1, 1864 edition of the Whig noted that a starving fifteen-year-old woman appeared in the market one day with a four or five-week-old baby whom she was no longer able to care for. Upon offering her baby to anyone who might be able to take better care of it, the distressed woman began handing her child to "an old negro woman." The Whig lauded the efforts of three ladies who immediately rushed to the poor woman's side and prevented her from handing the baby over to the "negro"- a clear example of moral charity on their part. Upon the orphan asylum's denial of the child due to its young age, a "respectable Mrs. P." graciously took the child and agreed to care for it temporarily while the young woman, a refugee schoolgirl from North Carolina and child of a widow herself, ultimately received assistance both from the three ladies and the city. ${ }^{466}$ These ladies' dramatic public performance of a personal act of charitable patronage provides yet another window into the ladies' perceptions of their moral duties and social responsibilities to the public during the late war years. However, the paper's broadcasting of the incident and its lavish praise of the women helped to reinforce, in writing, the powerful meaning and significance of an otherwise silent, symbolic act.

A final and important set of social interactions through which Richmond's leading ladies, side-by-side with their men, exhibited their worldviews on the merits of benevolence stems from

465 Richmond Daily Dispatch, February 19, 1862, March 29, 1862, May 7, 1862.

466 Richmond Whig, August 1, 1864. 
the relationship between elite women, their slaves, and free blacks. Admittedly, these interactions differ from previously discussed examples of elite charity toward poor whites in terms of the enormous differences in moral and human worth with which elite women viewed blacks and poor whites. Additionally, white women feared the far-reaching and destructive impacts of a black rebellion far more than they did the infiltration of lowly whites into the sacred fanes of Richmond's high society. Thus, the social, political, and economic stakes resting on women's careful management of their relationship with blacks were infinitely higher and often resulted in the ladies' more forceful displays of authority when dealing with slaves and free blacks. However, even interactions with the black population required the display of some benevolent care on the part of the elite in order both publicly (and mentally) to legitimize the moral authority of the elite over their slaves and to try to compel the deference of the slaves to their masters and mistresses. Through a series of calculated, charitable indulgences that balanced forcible displays of authority with necessary (though small) acts of placation, the leading ladies constantly sought to reaffirm the loyalty and good behavior of their frequently unruly slaves.

Admittedly, it is impossible to deny definitively that southerners ever felt any genuine, paternal concern for their slaves. It is also difficult to ascertain whether or not they consciously viewed their "benevolent" acts as a performance or method of social control, or whether they were merely acting according to notions of paternalism that had shaped their lives from birth. As Eugene Genovese, among others, has pointed out, the belief in the paternalist nature of the peculiar institution cast a powerful spell over the minds of the South's white masters and mistresses. ${ }^{467}$ Women such as Judith McGuire seem genuinely to have felt that the control that they exerted over their slaves was not just a necessity, but that it was also a moral good for the

\footnotetext{
${ }^{467}$ For a more in-depth discussion about the culture of paternalism, see Eugene D. Genovese and Elizabeth Fox-Genovese,
} Fatal Self-Deception: Slaveholding Paternalism in the Old South (New York: Cambridge University Press, 2011). 
slaves' own protection and well being. When scores of slaves from the Richmond area escaped to Union lines during the 1864 Overland Campaign, McGuire lamented that they had left behind the supposed comforts and care of their masters and mistresses, and instead had "gone to homeless poverty, an unfriendly climate, and hard work." "Many of them" were "to die without sympathy," McGuire claimed, "for the invalid, the decrepit, and the infant of days have left their houses, beds, and many comforts, the homes of their birth, the masters and mistresses who regarded them not so much as property as humble friends and members of their families Poor, deluded creatures!"468 However, both McGuire and her fellow white southerners wrote more pointedly and forcefully about the need to control blacks' behavior than they ever did about lowly whites' behavior. The pervasive need and desire to constantly assert social authority over the black population was so ingrained in southern whites' minds that it dramatically infiltrated and shaped-however sub-consciously — the contractual relationship between whites and blacks in which whites ritually offered to blacks calculated, charitable indulgences in return for their loyalty. ${ }^{469}$

Throughout the war, Richmonders, like most southerners, lived in continuous fear of a slave rebellion. Memories of Nat Turner's 1831 Rebellion and Gabriel's (suppressed) Rebellion of 1800 haunted their minds. In fact, the City Guard that Mayor Mayo and Governor Letcher called forward to quell the Bread Riot of 1863 was created in direct response to Gabriel's Rebellion to prevent further rebellions from occurring within the city limits. ${ }^{470}$ With so many

\footnotetext{
468 McGuire, 185, 279, 358. This account again clearly bears the taint of post-war Lost Cause nostalgia. However, it is likely that part of the reason why such nostalgia remained so ingrained and prevalent in writings of the postbellum era was that it contained nuggets of truth-perhaps not in terms of factual occurrences, but in terms of how southerners felt or perceived certain occurrences or relationships to have existed at the time. Therefore, we can conclude that this statement by McGuire about her perceptions of slaveholders' (and her own) treatment of slaves and slaveholders' perceptions of their relationships with their chattel reflects at least some elements of her own wartime views. 469 Genovese, Roll, Jordan, Roll, 51, 27; Wyatt-Brown, 154-186; Fox-Genovese, 132; McGuire, 358.

470 Wyatt-Brown, 157.
} 
men off fighting in the army or preoccupied with other war-related labor, and living in a city with a slave and free black population that numbered over 14,000, Richmond women and those men who remained at home feared an uprising by the increasingly "troublesome" black community. ${ }^{471}$ They also feared that an uncontrolled black population might result both in more runaways, which would in turn further deplete the city's wealth and war-time workforce, and an increase in black "uppityness," which might further threaten the city's precarious social order.

Richmonders had legitimate cause for concern. Black prostitution flourished during the war and the ensuing raucous behavior, debauchery, and depravity that plagued white houses of ill-fame permeated the black bordellos as well. ${ }^{472}$ On February 4, 1862, the Examiner reported that a disconcerting number of " $100+$ negroes" were attending the nightly entertainments at the Metropolitan Hall and had somehow managed to acquire bowie knives and pistols. The police were forced to repeatedly "search the colored audience" after several stabbings and other rowdy incidents occurred in the "negro gallery.",473 Black vagrancy also proved a major problem in the city. An October 24, 1863 issue of the Examiner complained that, due to the recent crackdown of gambling houses in Richmond, many "able-bodied negroes" who had frequented such houses were now roaming the streets with nothing to do, riding in hacks, filling the third tier of the theaters with unsavory company, and "ogling negro wenches" and newcomers. ${ }^{474}$ A December, 1862 issue of the Examiner likewise raged that on the previous Sunday evening, "all negrodom broke loose" in Richmond, with thirty to forty blacks of "all shades, from swarthy black and kinky hair to light olive and straight hair" all arrested for wrong-doings and for wandering the

\footnotetext{
471 Thomas, 26, 28; Withers, 113.

472 Carey H. Latimore, IV, "Always a Minority": Richmond Area Free Blacks in the Civil War Era (PhD diss., Emory University, 2005), 172.

473 Richmond Examiner, February 4, 1862.

${ }^{474}$ Richmond Examiner, October 24, 1863.
} 
streets without passes from their owners. ${ }^{475}$

By March of 1864, anxious Richmonders blamed a lack of work, authority, and organized activities for the spike in black crime in the city. The Examiner stated that both citizens and police were required to guard against the "servile people," and that punishments for black crime must be increased. "What is a few lashes to the back of a slave, or the jail or penitentiary to free negroes, whose only care in this world is the gratification of the senses of hunger, sloth and sleep!" the Examiner proclaimed, calling out for yet another crackdown on such incidents. "The only punishment a menial fears is death!"476

Worse yet, Richmonders feared that insufficient surveillance and the lack of structure in the lives of the city's black residents were contributing to the increase in runaway slaves, who often received the help of the city's free blacks in securing their freedom. ${ }^{477}$ Even Varina Davis fretted over her apparent lack of control of her slaves when two different slaves—-first, her head coachman William Jackson, in the summer of 1862, and then two house slaves, James and Betsey, in the winter of 1864 — ran away, the latter two taking eighty dollars worth of gold and 2,000 dollars worth of Confederate money with them. ${ }^{478}$ Such incidents made Richmonders view their slaves with heightened suspicion, with many elites accusing blacks (and rightly so) of espionage and aiding the Union army. ${ }^{479}$

Additionally, increased episodes of thievery by slaves and free blacks deeply concerned Richmonders of all classes. Returning home from a starvation party late one evening in 1863, Constance Cary was alarmed to find an open window in her pantry, "the sillclutched by ten

\footnotetext{
475 Richmond Examiner, December 16, 1862.

476 Richmond Examiner, March 5, 1864.

477 Richmond Whig, March 5, 1864.

478 Cashin, 127, 143.

479 Latimore, 117; Chesnut, 153.
} 
vigorous black fingers." 480 Terrified that "the town was full of half-starved marauding negroes," Cary restrained herself from screaming, and instead slammed the window shut, "and the fingers withdrew suddenly." Cary immediately locked the window, lowered the blinds, then "tore, breathless, palpitating, and scared to death" upstairs to the safety of her friends. ${ }^{481}$ Similar episodes occurred across the city during the late years of the war, filling Richmonders with increased anxiety over the growing need to safeguard their personal stores. In fact, in the spring of 1864, when the Union army lurked dangerously on the outskirts of Richmond during the famed Overland Campaign, a stubborn Sarah Lawton actually refused her husband's orders to evacuate the city with a group of fellow female friends, citing as justification her strong distrust of leaving her valuables "to the mercy of the negroes and the fortunes of a disorganized city." The proliferation of slave theft during the late-war years, particularly of delicacies and fashion finery, deeply concerned wealthy Richmond residents who feared that they might never be able to quench their slaves' seemingly endless thirst for material goods, fine food, and drink. ${ }^{483}$ How could they—or should they—prevent such brazen theft in the future, they wondered?

Richmonders knew that the success of the Confederacy demanded the loyalty and hard work of the black population both at home and in the direct war effort, as well as blacks' respect for elite authority and privilege. ${ }^{484}$ Additionally, the constant threat of the unraveling of Richmond's social fabric from all corners first necessitated the restoration of racial order upon which the hierarchy of southern society was based. Richmonders were growing alarmed at the number of "balls," dinners, "promiscuous dances," and other gatherings that the city's slave and

\footnotetext{
480 Thomas, 169.

481 Harrison, 134.

482 Sarah Lawton to her sister Louisa, May 16, 1864, in Boggs, 267.

483 Richmond Examiner, October 6, 1863, September 29, 1864; Latimore, 120.

${ }^{484}$ Richmond Enquirer, January 20, 1865.
} 
free population appeared to be both hosting and attending on a grander scale than ever before. ${ }^{485}$ At such gatherings, blacks — some with passes, but some without — would often spend the evening dancing, drinking, and frequently engaging in raucous or even violent behavior, and, even worse, putting on pretentions of whiteness. ${ }^{486}$ These gatherings, Richmonders feared, also might serve as a venue for troublemaking slaves to inculcate the fire of rebellion among their peers.

Numerous times during the war, the City Council attempted to restrict the mobility of the city's black population as well as its access to certain spaces. In 1863, the Council declared that no black person could enter the city, even for trade, unless he or she held a pass issued by the justice of the peace and endorsed by the Mayor. Checkpoints at Rocketts and the city markets helped to restrict black mobility in and out of the city, while Mayor Mayo instituted a new law requiring pass violators to be sent to work immediately on the Confederate defenses. Slaves who committed serious repeat offenses, as well as free blacks who violated laws against mass congregation, rowdy behavior, and public drinking could be whipped, jailed, sold (back) into slavery, and even transported to the Deep South. ${ }^{487}$ However, blacks' continued flouting of even the strictest legal codes gave Richmonders even more cause for concern. Clearly, many white residents thought, the black population needed still more regulation of its daily social activity in order to prevent larger episodes of social (and ultimately political) unrest. The only question was how to regulate such behavior.

Since the early days of slavery in the South, slave-owners had long considered their daily dispensal of food, shelter, clothing, and "protection" as part of their paternalistic responsibility to

485 Richmond Whig, March 26, 1864; Takagi, 101-2.

486 Latimore, 125, 142.

487 Latimore, 138, 142. 
provide for their supposedly helpless chattel. In return, they expected slaves to work hard and remain loyal to their master's family. In fact, master/mistress-slave relationships formed the backbone of most southerners' understanding of the definition of charity. ${ }^{488}$ Historian Carey Latimore has referred this engagement between wealthy whites and both slaves and free blacks as a "benevolent despotism."

As an addition to this daily charity, white slave-owners had carefully crafted the opportunity for "Free Sundays," holiday get-togethers, and the occasional "negro party," which had been a long-standing tradition for slaves in the pre-war South. Antebellum slave narratives abound with descriptions of festive gatherings on Sundays, Christmas, New Years, and other special occasions during which masters and mistresses released their slaves from their labor obligations, granted them short-range travel passes to the city and other plantations to see family and friends, and supplied them with copious amounts of whiskey, dinner delicacies, and handme-down clothes. ${ }^{490}$

\footnotetext{
488 Genovese, Roll, Jordan, Roll, 75-86; Fox-Genovese, 32.

489 Latimore, 91.

490 Frederick Douglass, My Bondage and My Freedom (Miller, Orton, \& Mulligan, 1855); reprint, ed. John David Smith (New York: Penguin Group, Inc., 2003),184-188, 103, 106-8, 73-4; Harriet Jacobs, ed. Lydia Marie Child, Incidents in the Life of a Slave Girl (Boston, 1861), in eds. William L. Andrews and Henry Louis Gates, Jr., Slave Narratives (New York: Literary Classics of the United States, Inc., 2000; reprint, 2001), 775, 799, 773, 760; William Wells Brown, Clotel; or, The President's Daughter (Great Britain: Partridge \& Oakey, 1853); reprint, ed. M. Giulia Fabi (New York: Penguin Group, Inc., 2004), 179, 45-7; Louis Hughes, Thirty Years a Slave: From Bondage to Freedom, The Institution of Slavery as Seen on the Plantation in the Home of the Planter (Milwaukee: South Side Publishing Co., 1897); reprint, (Montgomery, AL: NewSouth, Inc., 2002), 40, 43-5, 54, 33, 19, 113, 120, 74, 22; Solomon Northup, Twelve Years a Slave (Auburn, NY: Derby and Miller, 1853); reprint, (Mineola., NY: Dover Publications, Inc., 1970; reprint, 2000), 169, 213, 215, 217-8, 221; Kate Drumgoold, A Slave Girl's Story (Brooklyn, NY, 1897); in ed. Henry Louis Gates, Jr., Six Women's Slave Narratives, The Schomburg Library of Nineteenth-Century Black Women Writers (New York: Oxford University Press, 1988), 4-5; Mary Prince, The History of Mary Prince, a West Indian Slave (London: F. Westley and A.H. Davis, 1831), in ed. Gates, Six Women's Slave Narratives, 1; Frances E.W. Harper, Iola Leroy, or, Shadows Uplifted (Philadelphia: Garrigues Brothers, 1893); reprint, ed. Gates, Six Women's Slave Narratives, 25-26, 151; William Wells Brown, My Southern Home: or, The South and Its People (Boston, 1880); reprint, New York: Mentor Books, 1993; reprint, ed. William L. Andrews (Columbia, MO: University of Missouri Press, 2003), 43, 201, 180, 182. William Wells Brown, ed. John Ernest, The Escape; or, A Leap for Freedom (Knoxville, TN: The University of Tennessee Press, 2001), 8-10, 18, 23, 25-6; Henry Box Brown, ed. John Ernest, Narrative of the Life of Henry Box Brown, Written by Himself (Chapel Hill: The University of North Carolina Press, 2008), 62, 70-1; Henry Bibb, Narrative of the Life and Adventures of Henry Bibb, An American Slave, Written by Himself (New York, 1849); in eds. Andrews and Gates, Slave Narratives, 445-446; Annie L. Burton, Memories of Childhood's Slavery Days (Boston: Ross Publishing Company, 1909); in ed. Gates, Six Women's Slave Narratives, 5; William Grimes, Life of William Grimes, The
} 
Slaveholders had long permitted such gatherings in order to routinely placate the desires of their potentially rebellious slaves while simultaneously hoping to reassert their power over the slaves through this performance of master/mistress patronage. No strangers to the practice of silently negotiating with their masters and mistresses for greater agency and freedom, many slaves were well aware of the power implications of such behavior. ${ }^{491}$ Thus, they indulged in their temporary "freedoms" while continuously negotiating with their masters and mistresses for yet more "freedom" in return for supposedly "good" behavior.

However, freed slave Frederick Douglass saw both the advantages and dangers in such demonstrations of white paternalism and "benevolence." ${ }^{492}$ In his classic 1855 narrative, Douglass wrote that, while these "mini-holidays" gave slaves a respite from the harsh conditions of chattel labor, they also had the ability to dupe more naïve slaves into deception about the horrors of slavery and the manipulative cruelty of their masters. As a result, the holiday rituals served as some of slaveholders' most effective means to suppress the "spirit of insurrection among" their slaves. Douglass realized that in order "to enslave men, successfully and safely, it is necessary to have their minds occupied... with pleasures in prospect....and pleasures of memory" which thereby served to "keep out thoughts and wishes of a more dangerous character." The holidays produced exactly this "preoccupying effect" of keeping the slaves so engrossed in the prospect of imminent pleasure that they did not dwell on the "thoughts and aspirations of liberty of which they are deprived." Without these routine indulgences, Douglass

Runaway Slave (1855); reprint, eds. William L. Andrews and Regina E. Mason (New York: Oxford University Press, 2008), 39; William Wells Brown, "Under the Stars and Stripes," in eds. Philip S. Foner and Robert James Branham, Lift Every Voice: African American Oratory, 1787-1900 (Tuscaloosa, AL: The University of Alabama Press, 1998) 211-213; John Mercer Langston, "There is No Full Enjoyment of Freedom For Anyone in This Country," in eds. Foner and Branham, Lift Every Voice, 277; Frederick Douglass, "What, to the Slave, is the Fourth of July?" in eds. Foner and Branham, Lift Every Voice, 258, 248-9, 269.

491 Genovese, 7. Glymph, 108, 91

492 See Wyatt-Brown, 151-186. 
was convinced, the "South would blaze with insurrections." In fact, Douglass believed that slaveholders' holiday rituals were so powerful that he feared that slaves would lose their rebellious spirit altogether during such holidays and instead allow themselves to be lulled into submission by the master's indulgences.

Douglass counseled that only through informed and measured enjoyment should a slave ever indulge in his or her master's or mistress's gifts. However, such was not always the case. Over-indulgence, especially, which occurred all too often when masters and mistresses meted out gifts of whiskey over Christmas and New Years, also had the potential ability to convince blacks that they were not, in fact, able to responsibly control themselves during such episodes of "freedom," and therefore that such freedom was ultimately wrong, painful, and harmful to the slave community. Douglass himself worried that such over-indulgence in the gifts of ostensible "freedom" ultimately might have the potential to turn slaves away permanently from seeking true freedom altogether in the future. Thus, Douglass bitterly concluded,

the holidays become part and parcel of the gross fraud, the wrongs and inhumanity of slavery. Ostensibly, they are institutions of benevolence, designed to mitigate the rigors of slave life but practically, they are a fraud, instituted by human selfishness, the better to secure the ends of injustice and oppression. ${ }^{493}$

With such a tradition already established prior to the war, it is no wonder that Richmond slaves expected the continuation of such gatherings during the war itself. Richmond's slaveholding capital elite certainly saw the merits of such a system, and encouraged the balanced indulgence of their slaves in return for their (forced) submission to their masters' and mistresses' authority. In the words of Kate Logan, it was elite women's “duty to look after the comfort of those in our domestic circle...there was mutual benefit obtained, for we were good to them and

493 Douglass, 185-6. 
they were good to us.",494 Even despite a January 1, 1863 law prohibiting future "negro gatherings" in the city, due to rowdy behavior and citizens' complaints, ${ }^{495}$ many of the men and women of the capital elite continued to make use of the system of calculated indulgence and restraint — a staple without which, many feared, they might lose their already delicate control of the large black population. However, debates raged as to just how much leniency to provide to the African-American population.

A December, 29, 1863 issue of the Examiner and a December 2, 1863 issue of the Dispatch lamented the threats and anxieties which the freedoms given to the city's slaves during holiday and hiring week, the week between Christmas and New Years, had produced. During this annual period, slaves notoriously spent the week visiting and making revelry with friends and family while roaming the streets in search of a new employer to hire themselves out to for the next year. ${ }^{496}$ The Dispatch fumed, that "if there is any one evil permitted in our midst which should more than any other be put a stop to, it is that of suffering negro slaves to hire their own time." The editors of the Dispatch firmly believed that "much evil results from giving them this wide license, both to their own ultimate value and to the interests of the residents living in neighborhoods with them." Citing the recent increase in robberies and theft in the city in which slaves were found to be complicit, the paper concluded that, "it is fair to presume that hiring them their own time is no advantage to their morals, and does not enhance their value to their owners." $" 497$

Likewise, by January, 1865, the Enquirer was deeply lamenting the negative

\footnotetext{
494 Logan, 29.

495 Richmond Examiner, January 1, 1863; Richmond Whig, January 1, 1863.

496 Richmond Examiner, December 29, 1863; Richmond Daily Dispatch, December 2, 1863.

497 Richmond Daily Dispatch, December 2, 1863.
} 
consequences of allowing slaves such freedom during hiring week and questioned whether society must strike a more careful balance between such indulgence of their slaves and the necessary exertion of control over them. Such questions were particularly pressing after nearly four years of war which had seen the incidents of black crime and rebelliousness and the number of runaways skyrocket to numbers injurious to the maintenance of order and stability within the Confederate capital. According to the Enquirer, by 1865 there were now "many more negroes who now hire themselves out...[they have] too much freedom, searching for a hiring 'master' with little to do, and plenty of opportunities for stealing." Furthermore, with Sundays already serving as additional free days for slaves, hiring week gave the slaves of "indulgent masters" plenty of chances to run away. It was "sadly demoralizing," the Enquirer went on, to read the police reports and see that "quite clearly," their masters "cared nothing for them" in allowing the slaves a full week away from the "care and protection" of their masters and mistresses, which undoubtedly was responsible "for all the secret growth of theft, lawlessness, disregard and contempt of restraint." ${ }^{498}$ Were masters' "indulgence" of their slaves during hiring week truly charitable and performed with the best of intentions after all, the editors wondered, or were such supposed kindnesses destroying one of the most intregal parts of Richmond's social fabric?

Other newspaper articles angrily noted the increase in thefts around Christmas time and beseeched Richmonders for a solution to such holiday mischief. A December 1861 issue of the Dispatch reported that Taylor Mills, "a free negro, while collecting the ingredients for his Christmas eggnog, became indignant at the high prices of things generally, and thought he would do a cute thing to save his spondulicks; so he stole a lot of eggs from Jack Smith, and slyly put

498 Richmond Enquirer, January 2, 1865. 
them away for the holidays," 499 while on Christmas Day itself, Oliver, "a negro who felt Christmas all over him, stole a bottle of brandy, a canteen or rum, and a ham of bacon from his master."500 That same Christmas, the police arrested twenty-two blacks who had "unlawfully congregated for the purpose of having a high old time," and the Dispatch cautioned "owners and employees... of giving their servants liberty to attend these social gatherings."501

However, masters and mistresses considered both the holiday week and the freedom of hiring week as merely a necessary extension of the daily charity of food, shelter, and "protection" that they already dispensed to their slaves as part of the "paternalist" institution. Additionally, they relied upon such performances - however subconscious — of charity as a critical means of both social and racial ordering. Ladies such as Mary Chesnut, Varina Davis, and Constance Cary Harrison encouraged their own slaves, as well as the slaves of their peers, to engage in ritualistic revelry and indulgence. Chesnut regularly gave her slave Laurence passes to attend the low-profile "negro balls" in Richmond, and even allowed him to drink to the point of severe intoxication on New Years Day. ${ }^{502}$ Meanwhile, Constance Cary wrote of sharing the enjoyment of the Christmas, 1863 holiday with her friends and slaves at a mansion in neighboring New Kent. Cary wrote, perhaps exaggeratedly but still informatively, of the pleasure that her slaves received from such "treats," describing it as the "intense enjoyment" of the "happy negroes" at her friends' home. Cary notes that all the slaves shared "old time luxuries of partridges, sugar cured ham, spare ribs and sausage...corn pone, biscuits, fresh butter, pitchers of cream, fresh coffee, lavender scented linen, feather beds and a fine fire."

Doubtless, this statement, too, was exaggerated for post-war effect to celebrate the "great

499 Richmond Daily Dispatch, December 20, 1861.

500 Richmond Daily Dispatch, December 25, 1861.

501 Richmond Daily Dispatch, December 30, 1861.

502 Chesnut, 458, 526.

503 Harrison, 168. 
generosity" of slaveholders and their mistresses. However, it is still highly likely that the Cary family slaves received at least small portions of these rare treats as part of their annual "holiday indulgences" to which Frederick Douglass and other slaves frequently alluded in their narratives.

Sallie Putnam's friends did the same, "absolving the faithful domestics from their regular duties" and encouraging them to come in for a "share of the bounties — an extra shawl, a bright plaid kerchief, a pair of gloves or cast off clothes showed that they were not forgotten." In a particularly illuminating display of the reciprocity of such patronage, Putnam noted that often, the "faithful slaves" would in turn give a gift to their masters. ${ }^{504}$ First Lady Varina Davis likewise opened her holiday celebrations to her remaining slaves in 1864 when she allowed them to indulge in several glasses of rich eggnog, supposedly in the same room as the family and some of Varina's friends. ${ }^{505}$

Varina had demonstrated a particular care for the well-being of young slaves when, while riding through the city in the winter of 1864, she had rescued a black boy named James Brooks from a black man who was beating him relentlessly on the street. Varina jumped from the carriage and ordered the man to cease his assaults on the boy, whom she ultimately took home with her. Varina purchased freedom papers for the orphaned boy and essentially adopted him into her home as a playmate for her own young children. ${ }^{506}$ This tremendous display of charity for the black boy and her allowance of his semi-assimilation into white society through acceptance into her family reveals both the kind heart of the First Lady and her belief that it was her responsibility to care for this boy as a supposedly benevolent, slaveowning mistress herself. Varina's inclusion of slaves and a free black child into her family, even if only on a temporary

\footnotetext{
504 Putnam, 89.

505 Varina Davis, “Christmas in the Confederate White House,” New York Sunday World, December 13, 1896.

506 Cashin, 145.
} 
basis, was certainly unique in its own right. However, such practices stem from similar instances in the antebellum era that blended into the Civil War, when wealthy white women often engaged in similar actions of mistress-slave patronage and imposed domestic authority over their slaves by choosing when to provide assistance, food, and clothing for slave weddings and other slave family events. ${ }^{507}$ Therefore, it is important not to conflate Varina's adoption and care of James Brooks—who ultimately became merely a "play-thing" for Varina's son—entirely with notions of selflessness and open-minded charity on Varina's part, but rather as part of yet another ingrained "ritual" or tradition in the life of a leading southern lady.

Constance Cary's writings about her own daily interactions with her slaves highlight the continuation of such traditions. On several occasions Cary mentioned writing letters on behalf of her housemaid, Emily, to Emily's fiancé who was owned by a different mistress. Emily had beseeched her for help in keeping in touch with her fiancé, but was herself almost entirely illiterate. Additionally, in 1863 Cary wrote of attending a slave's baptism ritual in a mill pond, and of donating an old petticoat of pigeon's neck silk to a slave woman named Dilsey whom she had met during a visit to the countryside. ${ }^{508}$

Cary's charitable contributions to the well-being of both her own slaves and to those of her close friends seemed quite often to produce more than sufficient rewards. Dilsey ultimately sent Cary a basket full of turkey, sweet potatoes, apples, and chestnuts during the autumn of 1863 in return for Cary's maternal kindness that summer. As Cary lived in the city, where food luxuries were often scarce or sold at extravagant prices, she was elated to receive Dilsey's gift. Instead of donating the food to the hospitals during her regular visits, Cary greedily kept the

\footnotetext{
507 Fox-Genovese, 132-5; Glymph, 89; also, see footnote 463.

508 Harrison, 144-6.
} 
luxuries for herself with which she hosted a lavish dinner party for several of her friends. ${ }^{509}$ Cary's calculated indulgence of the slave woman earlier that summer had paid off, as Cary had seemingly won the reciprocal allegiance of the slave woman who had made it possible for Cary to continue to enjoy her elite privileges that autumn. Dilsey's gifts also enabled Cary to continue hosting the dinner parties that Fall with which she sought both to maintain her high-ranking social status and to rally the spirits of the ruling elite during a particularly challenging time for the Confederacy.

As historian Thavolia Gymph notes, the life of a slaveholding woman was anything but that of a passive, shrinking violet when it came to managing the affairs of the household; in fact, Glymph argues that, much to their own undoing, many plantation mistresses continued to rely increasingly on pure force to attempt to control their slaves. ${ }^{510}$ However, as Glymph points out, the use of force alone did not always result in amenable results for white women. ${ }^{511}$ Thus, many southern ladies_-Richmonders included — frequently found themselves in constant negotiation with their slaves for power, continuously struggling to balance placating indulgence with force and restraint. Southern ladies' participation in this culture of reciprocal paternalism with their slaves was so all-encompassing that it infused nearly all of their social relationships and charitable activities. ${ }^{512}$ Although Richmond ladies' social interactions with slaves clearly differed in obvious ways from those with fellow white women, the ladies' attempts to control and bring order to the black population through a system of calculated indulgence and restraint provide a window into their inner perceptions of how to bring order to society as a whole.

\footnotetext{
509 Harrison, 144-6.

510 Glymph, 4-5.

511 Glymph, 100-105, 108

512 Fox-Genovese, 49; Genovese, 74.
} 
As Varina Davis, Mary Chesnut, Sallie Putnam, and their peers intimated through their writings, they remained perpetually on-edge throughout the war, wondering if their performances of calculated charity were enough to placate the black community into submission, while still impressing upon blacks the supreme power of the capital elite. ${ }^{513}$ Both male and female Richmonders knew that the survival of the Confederacy depended heavily upon the loyalty and contributions of both the poor white and black populations to the war effort. While Richmond ladies certainly did not feel such a direct and imminent threat to themselves and to society from poor white women as they did from the black community, the performative similarities of their charitable, yet authoritative actions on behalf of the poor and those on behalf of their slaves illuminate an overarching mindset about the relationship between charity and social order, and about the power of performance in making that relationship successful. For the ladies of the capital elite, the stage was always set for such performances, whether that performance was before the general public or merely a private audience.

As their disaffection from the masses of the city poor continued to grow throughout the late war period, Richmond's leading ladies appear to have convinced themselves that their charitable acts were best received, their benevolent behaviors better spotlighted and most influential, in the private sectors of the home and in the immediately surrounding neighborhood. Whether such was the case or not, the ladies also convinced themselves that word of their more private charitable acts would undoubtedly spread throughout the Richmond community, thus reinforcing their image and authority as legitimate, moral leaders of society.

Additionally, the ladies firmly believed that this more intimate form of personal charity would help more effectively to sort out the morally upright, "worthy poor" from the money-

513 Cashin, 127, 143; Chesnut 547; Putnam 264. 
squandering, "pretending poor." Convinced that their charitable selectivity would ultimately, truly help far more needy individuals and provide greater stability within Richmond society than would their participation in what they perceived to be the "corrupt," public charities for the masses, the ladies continued to direct their benevolence more inward. Ultimately, however, similar to the exclusive parties discussed in chapter two, these ladies' large-scale retreats from public spaces resulted in the proliferation of highly symbolic, but relatively insular elite engagements with the public. Thus, as Richmond's leading ladies increasingly distanced themselves, physically, from their constituency, so too did they socially from the very individuals whose loyalty and respect they so desperately sought to gain. Rather, the ladies' social rituals gradually morphed into pale shadows of their former selves in which Richmond's leading ladies remained steadfast in such practices, but became the mere, unwitting performers of a series of cultural scripts for an audience comprised entirely of their peers. 


\title{
Chapter 6-- "They Came to the Rescue as They Had Often Done Before": \\ Holiday Ritual and the "Last Confederate Christmas of 1864"
}

\begin{abstract}
$* * * * *$
That Christmas season was ushered in under the thickest clouds; every one felt the cataclysm which impended, but the rosy, expectant faces of our little children were a constant reminder that self-sacrifice must be the personal offering of each mother of the family. How to satisfy the children that nothing better could be done than the little makeshifts attainable in the Confederacy was the problem of the older members of each household...A debt of honor due from them to the season's exactions. These young people are gray-haired now, but the lessons of self-denial, industry and frugality to which they became past mistresses then, made of them the most dignified, self-reliant and tender women I have ever known - all honor to them. So, in the interchanges of the courtesies and charities of life, to which we could not add its comforts and pleasure, passed the last Christmas in the Confederate mansion.-Varina Davis, $1896^{514}$

$* * * * *$
\end{abstract}

In poignant remembrance of the final "Christmas in the Confederate White House," Varina Davis reflected upon this special event in an extended article for the New York Sunday World, some thirty-two years after the Confederacy's final Christmas. Varina recounted the event fondly and praised the transformation of her female peers into empathetic, yet powerful social leaders under the extreme duress of civil war. This unique event was organized and hosted in large part by the nation's First Lady. The last "Christmas of the Confederacy" in Richmond, Virginia is a fascinating lens into the evolution of Richmond ladies' social sensibilities and their combined use of a multitude of rituals to try both to combat the immense social disorder within the Confederate capital during the trying days of the late war period, and to provide some sense of social stability for war-weary Richmonders. It also provides a valuable portal into the long-term effects of both the war and of the persistent civil unrest in the capital city upon both the mindset and response of Richmond's ladies to the challenges of the late-war period. Ultimately, however, despite their best efforts, this 1864 holiday observance reveals the

\footnotetext{
514 Varina Davis, “Christmas in the Confederate White House,” New York Sunday World, December 13, 1896.
} 
elites' tragic, yet unwitting, alienation from the general public, as well as their cognitive and physical disconnect from the larger society toward which their carefully crafted behaviors that holiday were fundamentally directed.

The Christmas, 1864 celebration occurred during the Confederacy's darkest hour. With General Robert E. Lee's besieged Army of Northern Virginia pinned down by General Ulysses S. Grant's Union army in the trenches of Petersburg, just twenty-five miles south of Richmond, with Union Generals Sherman and Sheridan in control of Atlanta and the Shenandoah Valley, respectively, and with the western theater firmly in the hands of the Union army, the Confederate capital found itself in dire straits by December 1864. To make matters worse, that Fall, Union forces had seized control of a key series of forts along the James River near Chaffin's Farm, nearly surrounding and severing the Confederate capital from its major supply lines. The Confederate armies desperately needed food, clothing, and other vital supplies to help sustain them through the long winter ahead. However, Richmond civilians, starved, anxious, and weary from years of seemingly relentless combat upon their doorsteps, also found themselves struggling for survival in late 1864. A short poem printed in the Richmond Daily Whig that Christmas season embodied the uncertainty and anxiety that plagued Richmond society during the fourth Christmas of the war: "Christmas old style, Christmas cakes and beer, Christmas comes but once a year. Christmas new style, bald faced whiskey, sour beer. Christmas - will it come next year?" 515

In many ways, the Christmas, 1864 celebration was merely a continuation of previous holiday traditions in the south. Since the early nineteenth century, Richmonders had celebrated Christmas with particular zeal. Christmas festivities had been a staple in the South since the

515 Lisa A. Bacon, “The Hungry Holiday of 1865," Style Weekly, December 23, 1991, 7. 
colonial era, a twelve-day celebration of food, drink, dancing and visiting. Christmas weddings, extravagant decorations and lavish feasts were cornerstones of southern culture, with such delicacies as turkey, calves' foot jelly, eggnog, iced cakes, "rosy apples in pyramids," terrapin stew, brandy and other cherished foodstuffs present at every elite Richmonder's table. Mistletoe, garlands, and kissing balls traditionally filled the hallways and dining rooms of each house with Christmas cheer. ${ }^{516}$ As historian B.C. Yates wrote in 1961, in the antebellum South and in the early war years, southerners had cherished Christmas as "both the reason and the excuse for parties, visits, feasts, exchange of gifts, and a generally happy time - a tradition long honored in the observance, and one that not even the War Between the States could nullify." Admittedly, the war had cast a more solemn shadow over the festivities, and in turn, the celebrations of many were "tempered by the absence of loved ones, and a day on which scarcities were noted." Nevertheless, Yates concluded, Christmas came and was commemorated with true Southern spirit. $^{517}$

However, during the war years, many Richmonders came to view some of the more elaborate celebrations of the Christmas holiday as both inappropriate during a time of war and potentially threatening to the social stability and morals of the city upon which the Confederate capital relied for maintaining order on the home front amidst the chaos of war. As Stephen Nissenbaum and Susan Davis have noted, Christmas revelry in the nineteenth century frequently disrupted public order and incited violence, debauchery, and general acts of public resistance to

\footnotetext{
516 Ruth Ann Coski, Christmas program notes, vertical files, Christmas file, Eleanor S. Brockenbrough Library, Museum of the Confederacy, Richmond, VA.

517 B.C. Yates, "Christmas in the Confederacy," Georgia Magazine (December 1961-January 1962), 16; Richmond Daily Dispatch, December 25, 1862.
} 
authority, especially in impoverished urban environments. ${ }^{518}$ Such rowdy revelry only increased during the four years of civil war, and particularly during the holiday season. Wealthy Richmonders such as Winchester refugee Mary Tucker Magill looked to the approach of Christmastime each year with an increasingly wary eye, noting,

there must be a surface to everything. As the pent up liquid comes into contact with the exhilarating air, it must vent itself in foam and noise, and so the feelings of the people were kept so constantly under a pressure that was soon as the opportunity presented itself, it would foam and bubble as was its nature to do, usually among the idler portion... who failed to realize the dangers. 519

As a result, during the Christmas season, Richmond's leading ladies relied on a combination of familiar social rituals of charity, promenading, visiting, attending and hosting exclusive parties, and church-going to transform Richmond into a metaphorical social theater. Upon the "stage" of this "theater" - that is, the streets, private homes, and public buildings of the Confederate capital — the ladies sought to inculcate moral behavior, respectability, and social order among the masses through conspicuous class delineation, appropriate inter-class engagement, and self-modeling of those cherished virtues that they believed were essential to maintaining stability within the city at Christmas time.

As the city newspapers reveal, the capital elite had increased cause to fret for the order of their beloved city with the passing of each Christmas. In anticipation of an unruly first Christmas Day in the Confederacy, a morning edition of the December 25, 1861 Richmond Daily Dispatch declared, "Pop-crackers and rockets, chasers, and Roman candles, completely upset the equilibrium of young Richmond last night. Let war or peace control the world as they may,

518 Susan Davis, “'Making Night Hideous': Christmas Revelry and Public Order in Nineteenth-Century Philadelphia," American Quarterly 34, no. 2 [Summer, 1982], 185; Coski, Christmas program notes; Stephen Nissenbaum, The Battle for Christmas (New York: Random House, Inc., 1997, 273.

519 Magill, 329. 
urchins will have their fun on the eve of Christmas day."520 ${ }^{, 5 a t e r}$ that December, the Dispatch cautioned its readers against such debauchery, writing rather that "the times are such as to demand the serious and sober contemplation of every individual" during the holiday season. ${ }^{521}$

Surprisingly, the Christmas of 1861 passed without much incident, nor with any major commentary from the newspapers or Richmond's diarists. According to Sallie Putnam, everyone was too busy sewing and cooking for the soldiers in the field and too shocked by the realities of war to engage in much revelry or social gayety. Indeed, she lamented, the hilarity and delight of former Christmases "mocked" Richmonders with their peace and happiness. ${ }^{522}$ The Richmond Daily Dispatch noted with great relief that "the Negroes behaved with great propriety on Christmas Day," and that, with the exception of the usual "undue proportion of whiskey" in the city's eggnog, most individuals used the holiday week to "reflect upon the ways and means to keep body and soul together," as holiday indulgences, the paper insisted, were "dangerous and expensive." 523

Even in December of 1862, Christmas passed in Richmond with seemingly appropriate celebration. The Richmond Examiner called the holiday "fairly tame," but acknowledged the usual "few drunkards and law breaking" on the crowded streets. The Varieties theatre experienced a few episodes of drunken yelling and even "stampeding," courtesy of both the audience's and the actors' indulgence in spiked eggnog, and the newspaper reported a fair amount of gambling on Christmas Day. However, the paper noted that the holiday largely consisted of merely the "usual recklessness" to which the city had grown accustomed after nearly two years of war. ${ }^{524}$ According to the Richmond Enquirer, the holiday produced only a slight

\footnotetext{
520 Richmond Daily Dispatch, December 25, 1861.

521 Richmond Daily Dispatch, December 31, 1861.

522 Putnam, 87-9.

523 Richmond Daily Dispatch, December 27, 1861, December 28, 1861.

${ }^{524}$ Richmond Examiner, December 27, 1862.
} 
uptick in disorderly behavior, with only a few popcrackers set off in the streets, and many Richmonders merely enjoying "golden cake and bon bons and eggnog bowls" from the elaborate Christmas displays in the city stores. Meat and fruits were in abundance that Christmas, and "huge, fat, crispy browned turkeys" offered up to buyers an "unspeakable bliss" in the midst of the anxieties of war. Though the Enquirer acknowledged that such delicacies merely "taunted" the poor, while serving as a "dainty pleasure" to the rich, the paper did not see much to condemn or fret over during the Christmas 1862 celebrations. ${ }^{525}$

Shortly after Christmas, however, on the evening of January 2, 1863, arsonists burned the old Marshall Theatre to the ground. The malicious act shocked Richmonders, whose previous disdain for and suspicion of the unruly theatre patrons of the third tier and balcony seats immediately caused them to suspect that the crime was committed by none other than some of these debauched incendiaries. ${ }^{526}$ Given the growing social tensions in the city, Richmonders suspected that frustration with the increased enforcement of order and sobriety in the theatrecombined with an excess of bad holiday whiskey and anger over the mounting economic duress in the city—and irritation with elite Richmonders' efforts to regulate the behavior of the city's "commoners" at numerous other public spaces had spurred the arsonists to action. In many ways, the theatre arson foreboded the upswing in holiday season crime and disorderliness that was to follow in the coming years.

By Christmas of 1863, incidents of riotous and scandalous behavior that holiday season flooded the columns of the city newspapers. With speculation running rampant among city storekeepers, impoverished Richmonders and "half clad urchins with blue noses and red cheeks" pressed themselves against the shops of the confectioners, book sellers, gin sellers, and

\footnotetext{
525 Richmond Enquirer, December 22, 1861.

${ }^{526}$ Richmond Daily Dispatch, December 2, 1863.
} 
toymakers in feverish hunger for delicacies, but also even basic items, which they desperately wanted and needed, but knew they could not afford. ${ }^{527}$ As a result, Christmas Day itself saw numerous riots across town by the poor of all ages who instead tried to appease themselves with cheap liquor and brawling. The Examiner reported an "overflow of boozy men into the theatre" that Christmas night, with fights in the parquette and the bars overflowing with rowdy customers. "Richmond rose with a headache and stomach pains the next day," the paper reported, with many individuals arrested and thrown into the "cage" overnight while they sobered up. ${ }^{528}$

Meanwhile, the Daily Dispatch reported a series of burglaries, including a theft of twothousand dollars worth of bacon, lard, sugar, and "other articles necessary to a proper enjoyment of the Christmas holiday" at the storehouse of Mr. James B. Foster, on the corner of $9^{\text {th }}$ and Cary Streets, as well as several brawls, public drunkenness, property destruction, and other violent behavior that Christmas. On December 28, 1863, the Dispatch claimed that "a good sized army" of offenders filled the Mayor's Court for having gotten drunk on "Christmas beverages, annoying sober people, fighting each other, kicking doors, breaking windows, and crying fire" and for making Broad street "hideous with their yells." The police had arrested one white woman for wearing men's clothes in the streets, and two women for "hair pulling and catscratching." For such "turbulent and disorderly" behavior and their forgetting of "all sense of propriety" due to their "few potations of the distilled damnation now served to the worshippers of Bacchus," the Mayor forced the dangerous rowdies to pay bail in order to keep the peace in the city. ${ }^{529}$

In addition to the raucous behavior of the white population during Christmas time, the holiday celebrations and increased boldness of both enslaved and free African-Americans

527 Richmond Examiner, December 22, 1863.

528 Richmond Examiner, December 28, 1863.

${ }^{529}$ Richmond Daily Dispatch, December 28, 1863. 
throughout the Christmas season also posed a growing threat to the social order of the city over the course of the war. As was discussed in chapter five, episodes of theft, arson, rowdy partying, and disorderly behavior on the city streets by the city's black population, along with an uptick in slave fugitives produced great anxiety for Richmonders who grew increasingly uneasy about even the most minimal amount of independence allotted to slaves during the holiday season. ${ }^{530}$

With the population continuing to expand at an unsettling rate with the continued influx of refugees, speculators, and other seemingly threatening strangers, and with social tensions continuing to build within the capital city during 1864, weary Richmonders looked toward the Christmas of 1864 with both hope and fear. The military fortunes of the Confederacy were bleak, and both shortage and overcrowded conditions in the city gave to Richmond what Sallie Putnam called a "worn, dilapidated look." While some young Richmonders refused to let themselves give in to despair that winter, other, older Richmonders despondently accepted that, in the words of Constance Cary, the "iron belt surrounding the south was gradually being drawn." 531 Cognizant that the increased social tensions and unruly behavior of the lower classes throughout 1864 might potentially produce the most raucous wartime Christmas season yet, Richmonders warily looked toward the holiday for at least minor relief from their sufferings.

As discussed in chapters four and five, elite Richmonders never believed that they would be able to maintain power over their inferiors and social order within the city merely by force. Achieving a proper balance between celebration and mirth on the one hand, and forceful selfdenial and solemnity on the other, was critical to maintaining social stability both in everyday life in the Confederate capital, but especially during the potentially raucous Christmas season. Frequently, achieving such a balance proved utterly impossible. However, the Richmond elite

\footnotetext{
530 Richmond Examiner, December 16, 1862, December 29, 1863; Richmond Daily Dispatch, December 2, 1863; Richmond Enquirer, January 2, 1865; Richmond Daily Dispatch, December 20, 1861, December 25, 1861, December 30, 1861.

531 Putnam, 315-317; Richmond Examiner, December 24, 1864, December 28, 1864; Harrison, 166.
} 
kept striving toward this goal. Thus, despite the lower classes' overly zealous and occasionally malicious celebrations of the holiday during the war, Christmas still remained, according to the Richmond Daily Dispatch, "the one deep, unfailing fount of joy and consolation....amid our tribulations.. ${ }^{532}$ Even for the suffering soldiers in the field, Christmas offered a necessary comfort, peace, and inspiration. General Lee himself agreed that Christmas revelry was an important relief for his besieged men guarding the outskirts of Richmond. Lee advised the young ladies of the Starvation Club to lighten the hearts of his men when they arrived for their Christmas furloughs, ${ }^{533}$ while numerous other generals organized a series Christmas dinners for their officers and provided special treats for their soldiers. Numerous soldiers reported feeling uplifted by such tokens of celebration, with one soldier writing that "We kept Christmas, and our hearts were lighter for it, and our shivering bodies were not quite so cold." ${ }^{\text {534 }}$

Despite the inevitable despondency inherent in Richmond's war-beleaguered society, and despite the military and material strains placed upon both soldiers and civilians in the Richmond area during the fourth winter of the war, the hope for an ultimate Confederate victory still shone faintly through the Confederate capital during the Christmas season of 1864 . Richmond's elites struggled to perpetuate their southern Christmas traditions in spite of, and indeed, in light of, the otherwise "solemn and despondent" mood in the starved-out city. ${ }^{535}$ The capital elite continued to embrace, both consciously and sub-consciously, essential elements of southern culture —elite patronage, benevolence and charity, honor, Christian ideals, communal sensibilities, and a highly performative, strongly hierarchical social structure based upon the forceful rule of the elite and

532 Richmond Daily Dispatch, December 24, 1864.

533 Coski, Christmas program notes.

534 John R. Braxton, “Christmas on the Rappahannock,” Civil War Times Illustrated, December, 1973.

535 Phoebe Yates Pember, A Southern Woman's Story, ed. George C. Rable (G.W. Carleton \& Company, 1879; repr., Columbia, SC: University of South Carolina Press, 2002), 77; Mary Tabb Johnston and Elizabeth Lipscomb Johnston, Amelia Gayle Gorgas: A Biography (Tuscaloosa, AL: University of Alabama Press, 1978), 65; See also, William Blair, Virginia's Private War: Feeding Body and Soul in the Confederacy, 1861-1865 (New York: Oxford University Press, 1998$), 9$. 
the garnering of middle and lower class deference - in their attempts to hold the Confederacy together, albeit through war-induced creative adaptation of many of those cultural practices. ${ }^{536}$ The "last Confederate Christmas" therefore is a particularly useful event through which to analyze elite women's full, late-war development of a culture of ritual to help reinforce social order in Richmond, as it reveals the ways in which appearance, behavior, social visits and parties, charity, identity projection, and socio-political engagement with the public coalesced into a specific, highly crafted cultural script by the end of the war. However, it also illuminates the late-war transformation of Richmond ladies from more public social actors into more inwardfocused models of ladyship and agents of moral respectability. As the previous chapters have noted, the ladies' gradual retreat from the public sphere during the war, due both to fear and disenchantment with the increasingly diverse, rowdy, and immoral congregations of refugees in the Confederate capital, resulted in the even more careful selection and re-crafting of social rituals. These rituals assumed a far more intimate nature, and ultimately a more symbolic than functional purpose, in defending the women's claims to elite ladyship and in attempting to impose social and moral order upon society. Thus the rituals, such as Christmas celebrations, included a much narrower and exclusive group of individuals whose interactions more often resulted in more of a comforting, symbolic set of performances for each other, rather than in an inspiring and stabilizing ritual for the benefit of the broader public.

The immense amount of effort invested in the Christmas celebrations - and particularly the last Confederate Christmas of 1864 -reveals the importance that the ladies continued to ascribe to such rituals throughout the war as opportunities for the affirmation of identity and

\footnotetext{
536 Eugene Genovese, "Yeomen Farmers in a Slaveholders' Democracy," Agricultural History 49, no. 2 [April, 1975]: 340; Stephanie McCurry, "The Two Faces of Republicanism: Gender and Proslavery Politics in Antebellum South Carolina," Journal of American History [March, 1992]: 1263.; See also, Eugene Genovese, The Slaveholders' Dilemma: Freedom and Progress in Conservative Thought, 1820-1860 (Columbia, SC: University of South Carolina Press, 1992); See also, Bertram Wyatt-Brown, Honor and Violence in the Old South (New York: Oxford University Press, 1986), 12.
} 
social authority. Due to their narrow scope, the influence of these later rituals on Richmond society as a whole never (realistically) would have been as far-reaching as earlier, more public rituals. However, the ladies remained steadfast in their executions of them. Their commitment to these rituals may have emanated either from sheer denial of the narrow potential impact of the rituals upon their maintenance of authority and order in Richmond society, or from a headstrong belief that the war's widespread destruction and disorganization of society necessitated the more private execution of such rituals in order for the ladies to maintain any influence over society. Such commitment also may have been driven by the ladies' sheer desperation to preserve some sense of normalcy for themselves during the unsettling final months of the Confederacy. Perhaps shockingly for them, the contemporary written coverage of the 1864 Christmas event is absolutely minimal, with the few traces of written reference to it dating to the post-war era. ${ }^{537}$ Hence, it is doubtful that the actual influence of this ritualized celebration was significant beyond the sphere of those select few who participated in it. Therefore, the following discussion about the 1864 Christmas celebration in Richmond focuses more on the ladies' perceptions of the influence and symbolic power of their carefully sculpted actions, rather than on the realistic potential of that influence upon broader society.

\footnotetext{
537 As the footnotes in this chapter indicate, the majority of the evidence concerning the Christmas, 1864 event stems from the post-war accounts of individuals such as Varina Davis, Clara Lynn Minor, and Alice West Allen. Varina's account was written specifically for publication in Henry Pulitzer's New York World newspaper in 1896-the height of the Lost Cause era, while the other accounts were also written (though for unknown audiences) around the same time period. This, of course, naturally raises suspicions as to the truthful recounting of the event. While the frustrating lack of other contemporary accounts of the celebration has produced numerous questions for me personally, I have tried to use only portions of these accounts that I was able to corroborate both with secondary source material (such as the work of Stephen Nissenbaum) on nineteenth-century and Civil War Christmas celebrations and with other contemporary, general accounts of late-war Christmases and holiday celebrations. These latter sources, located in newspapers, diaries, slave memoirs, and letters of the period, all confirm certain key practices that Varina, Clara, and Alice mention in their own accounts, such as: Orphan visiting, public promenading, the organization of charitable feasts out of personal, excess stores and those sent in from the countryside, the re-tooling of old toys and scraps of cloth into special gifts for the less fortunate, the dispersal of eggnog to the family slaves, church-going, and exclusive "after-parties" for the elite. Although we may never know who, exactly, attended the 1864 Christmas in the Confederate White House and if our few accounts of that event are wholly accurate or if certain parts have been purposefully exaggerated or tweaked for public consumption, I feel fairly confident that the general description of the event that Varina and others have provided us has captured a solid, overarching picture of the components of this special event and the general spirit manifested therein.
} 
The last Confederate Christmas consisted of three main events: A Christmas Eve gathering of elite women at the Confederate White House at which the ladies (surrounded by slaves) jointly prepared gifts and a Christmas Day feast out of supplies sent in from the countryside for the orphans of St. Paul's Church; a Christmas Day service at St. Paul's, followed by a Christmas party for the orphans in the basement of the church; and an evening starvation party for the ladies (and their men) who had contributed to the success of the grand Christmas celebration. The ladies crafted the event as a response both to the needs and expectations of the general public, as well as to the desires and socio-political needs of the capital elite. In doing so, they transformed the last Confederate Christmas into what they perceived (however naively) to be a powerful stage upon which Richmond's leading ladies sought to demonstrate benevolent care for their social inferiors. In turn, they hoped, such displays might help to appease the potentially threatening anxieties and tensions within the poor community, while simultaneously reinforcing their own morale and their own power and identity as arbiters of social and moral order within the Confederate capital.

On Christmas Eve, 1864, Varina Davis invited a group of twenty ladies and their accompanying men to the Confederate White House for a decoration and toy-making party to benefit the young orphans of the St. Paul's Episcopal Church Home. By organizing this event on her own, Varina - the First Lady of the Confederacy and the figurehead of Confederate societydemonstrated an impressive cultural authority that was heavily rooted in the strong, ritualistic traditions of elite female benevolence noted throughout this dissertation. By claiming singular feminine control over the Christmas celebration, Varina transformed this cultural event into a fascinating set of social and political statements that encapsulated Richmond ladies' worldviews of their social privileges and responsibilities. Varina's organization of the event also illuminates 
the capital elites' perceptions of carefully scripted social engagements and cultural rituals as vital forums for the projection of their unique identity and authority with which they sought to reify the order and stability of the Confederate capital by the late-war period.

Although Richmond ladies had long been accustomed to extravagant gatherings at their friends' homes during each Christmas of the war thus far, the gathering at the White House on the last Christmas Eve of the war proved unique with its celebration of self-denial and its strong charitable undertones. During previous Christmases, the female elite had enjoyed lavish dinners and parties with their closest friends which proved the envy of the poorer contingent of the Confederate capital. As Constance Cary noted, over the course of the war, the city elite had seen noticeable reductions in their own tables' offerings each Christmas, with much of the plum pudding, oranges, apples, and wine sent off to the local hospitals. ${ }^{538}$ However, many of the female elite still enjoyed the privilege of attending sumptuous Christmas dinners at their friends' homes by late-war, with Constance Cary herself indulging in partridge, sugar cured ham, spare rips, sausage, fresh butter, cordials, cakes, plum pudding, and ice cream. ${ }^{539}$ Thus, despite the war's infringement upon nearly everyone's Christmas celebrations, Richmond's leading ladies had previously managed to perpetuate such lavish feasts and entertainments every December.

In fact, according to Sallie Putnam, the homes of the elite almost always brimmed with turkey, mince pie, and eggnog bowls while the children sang about Santa Claus and his bravery in delivering toys through the blockade. ${ }^{540}$ The ladies decked their homes with evergreens and holly while the Christmas tree annually "reared its cheered head, laden with a precious and incongruous burden of bon bons and simple toys."541 Anita Dwyer Withers enjoyed many a

538 Harrison, 166.

539 Harrison, 169.

540 Putnam, 267.

541 Putnam, 341. 
Christmas celebration at the homes of Richmond's most respected hostesses, including a Christmas Eve, 1861 fancy dress party at Mr. and Mrs. Matthew Maury's home where the guests enjoyed a fine dinner and piano music with the Confederate naval hero and his wife, a Christmas Day gathering with eggnog at the Purcell mansion, and an evening of dance and violin music at the home of the Nelson family on December $26 .{ }^{542}$ Withers enjoyed a similar celebration on Christmas Day of 1863 when she dined on large cakes, jelly, wine, and Blanc Mange with the prestigious Williams, Wade, and Myers families. ${ }^{543}$

Even refugee Judith McGuire guiltily enjoyed a Christmas, 1863 dinner of white and sweet potatoes, cabbages, butter, sausage, chines, and ham sent in to her from a relative in the countryside, as well as two pounds of green tea from a local friend. Despite her continuous anxieties over the plight of the poor and her concerns over elite excesses, McGuire happily indulged in her Christmas gifts that year. ${ }^{544}$ During the Confederacy's last Christmas, McGuire found herself not nearly as flush with holiday delicacies, but still enjoyed a dinner of roast beef and hosted a small party for her friends on Christmas night with tea and ginger cakes. ${ }^{545}$ During the holiday week of 1864, McGuire also attended a dinner party at the residence of an esteemed local doctor (whom she only identifies as "Dr. G."), where she and the guests dined on "many nice things sent in by country friends," including sausage, beef, dried fruit, turkey." Again, however, McGuire could not help but feel pangs of guilt as she cleaned her plate, pained to tears by the fact that such gifts were "evidence of [others'] self denial, and not given from abundance. ${ }^{546}$

\footnotetext{
542 Withers, 61.

543 Withers, 116.

544 McGuire, 247.

545 McGuire, 323, 324.

546 McGuire ,325-6.
} 
Additionally, although largely free from the guilt that plagued McGuire during her holiday indulgences, Mary Chesnut enjoyed a festive December, 1863 trip with Mrs. Ould, Mrs. Randolph, the Lees, Maggie Howell, the Preston girls, and Mrs. Myers down the James River to visit a French frigate at anchor downstream. Chesnut and her peers delighted in a lavish dinner on the ship, where their unabashed eating habits led one accompanying officer to comment, "How Confederate women pitch into a good dinner! Where I have been, I saw them eat the last oyster!" ${ }^{547}$ Chesnut also continued to host her elaborate tea parties and dinners, though on an even grander scale for the holiday season, in the week preceding Christmas in 1863. Chesnut proudly presented a spread of game, partridges, butter and eggs, brandy, egg nog, and apple toddy for her guests, who, like Chesnut, pitched into the meal with shameless zeal. ${ }^{548}$ Likewise, the Preston girls repeatedly invited their favorite female elites to their own holiday gatherings that Christmas season where the ladies happily feasted on oyster soup, boiled mutton, ham, turkey, wild ducks, plum pudding, burgundy, sherry, and madeira wine, from which parties Mary Chesnut happily concluded "there is life in the old land yet!",549 Chesnut concluded her Christmas feasting with a "fairly simple" though clearly still lavish Christmas Day dinner of oysters, ham, turkey, partridges, and good wine with the Preston girls, General John Bell Hood, and a select few other guests.

The First Lady's Christmas celebration of 1864 featured very little of such former extravagance. There are undoubtedly a multitude of reasons for this scale-back in material indulgence. However, Varina and her peers likely were responding partially to the mounting complaints from their critics. Similar to the exclusive parties and other excessive public showcases of elite privilege and wealth noted in chapters one and two, elite ladies' lavish holiday

547 Chesnut, 496.

548 Chesnt, 507.

549 Chesnut, 515. 
celebrations had not escaped the critique of more sober-minded Richmonders. Both Willie Pegram's and Phoebe Pember's sharp condemnations of the elites' inappropriate levity and their "selfish indulgence" in excess and materialism mentioned in prior chapters were aimed particularly at the grand holiday and winter levees of 1863 and $1864 .{ }^{550}$ In December of 1863 , the Dispatch bemoaned the number of "Confederate Scrooges" who preferred to horde their food and supplies for their own extravagant Christmas celebrations rather than share them with the needy poor. ${ }^{551}$ Likewise, on Christmas Eve, 1864 the Richmond Daily Dispatch pointedly warned Richmonders against continuing to indulge in their yearly Christmas excesses that holiday season. "Incongruous and inconsistent as excess and intemperance have ever been in such a festival, they would be peculiarly disgusting and shocking in this hour of national trial," the paper declared. The Dispatch lectured, "There is a time for all things—at time to laugh and a time to weep - certainly this is not the time for insensate joy." 552

Citing the seemingly omnipresent “empty chair" at Richmonders' dinner tables, the destruction of thousands of homes, the "fruitful regions transformed into deserts; battlefields white with the bones of the unburied dead; hospitals crowded with sick and dying, and countless hearts breaking with the agonies of late bereavement," the editors deemed any joyful celebration that holiday season to be sacrilegious. Even for those few families who had been lucky enough to avoid such tragedy, surely empathy for their friends and neighbors would compel them to cease such heartless revelry, the paper proclaimed. "Or," the Dispatch went on, even "if the sorrows of others cannot touch our sensibilities, the possibility that their fate may be our own should serve to chasten the exuberance of natures which have never known affliction...amidst

\footnotetext{
550 Phoebe Pember, letter to Mrs. Gilmer, February 19, 1864, Southern Historical Collection, University of North Carolina (Chapel Hill, NC); Willie Pegram, letter to "Sister," February 11, 1864, Pegram-Johnson-McIntosh Papers, Virginia Historical Society (Richmond, VA).

551 Richmond Daily Dispatch, December 25, 1863.

552 Richmond Daily Dispatch, December 24, 1864.
} 
such calamities as have rarely visited the human race." Indeed, they noted, "with a vast army at our very doors thirsting for our destruction, and a powerful Government preparing to strike one more, and that a colossal blow, it would better become us...to wear sackcloth and ashes, and, upon our bended knees, and invoke the Almighty to spare his people, than to mark the hallowed festival of Christmas by scenes of intemperance and dissipation," the editors tried to convince their readers. They concluded by begging the less sober-minded population of Richmond to show sympathy for their fellow sufferers and at least be "moderate" in their enjoyments that Christmas season. $^{553}$

Since the start of the war, the city papers had urged the elite partiers to instead focus more of their holiday efforts on charity and benevolent activities. Unquestionably, the papers did not deny anyone their celebrations of the holiday. Indeed, the papers, like numerous generals, saw great merit in promoting the joy and hope of the Christmas season. In December of 1861, the Dispatch declared that "surely we hay have our pleasures at home as heretofore, relieved though they may be of excess." However, the paper did seek to inspire in its readers a new conception about the meaning of Christmas during a time of war, and propose suggestions for more appropriate ways to celebrate its arrival: "We can pledge the cup of kindness to the boys far away, who will be all the happier for the good wishes and tender thoughts around the family hearthstone, for which the busy whirl and work of life but seldom leaves a pause," the Dispatch stated. In fact, the editors saw great merit in pausing to remember "the times which have been, and to gather up all the kindly memories lying with them." Now, more than ever, after so much loss, grief, and suffering, it was necessary and indeed honorable to "remind our absent friends that they are not forgotten; and there is something in the great and general holiday that summons back the spirits of those we love, and makes them to be present with us." Therefore, if they

553 Richmond Daily Dispatch, December 24, 1864. 
celebrated with appropriate respect for those who had perished, the paper concluded, Richmonders could "afford therefore afford to be happy in the Christmas time, and we would advise none to restrict their enjoyment except by the bounds of decency and reason. There is no more harm now than heretofore in extending the old English greeting - 'I wish you a merry Christmas, And a happy new year; A pocket full of money, And a cellar full of beer!"’54

However, while it sanctioned respectful observances of the Christmas season, simultaneously, the Dispatch strongly encouraged an increase in "those acts of beneficence to all the gallant defenders of our country who may still need our aid" as well as to the poor and "the sufferers by fire and other disasters, and to those widows and orphans of our noble martyrs to liberty who may be absolutely destitute of the necessities of life, whilst surrounded by plenty and profusion." Such beneficence was a moral, and indeed, religious duty to those who had given so much for the sake of the Confederate cause. Indeed, the paper declared, "no Christmas gift can be more acceptable to God and man than gifts to such as these, and no appliances for making Christmas happy so effectual as those which impart to our own minds the assurance of having increased the happiness of others. ${ }^{, 55}$

Although the Richmond elite spent the Christmas holidays of the war years in far greater comfort than did their impoverished neighbors, they responded to their critics with concerted efforts toward assisting with relief for the city poor as well as for the wounded. Grand benefits held at the New Richmond Theatre, as well as numerous concerts, tableaux, charity dinners, and other events attracted a large number of the city's most distinguished civilians whose contributions of food, funding, and both their time and organizational skills buoyed the spirits

554 Richmond Daily Dispatch, December 24, 1861.

555 Richmond Daily Dispatch, December 25, 1861. 
(and stomachs) of suffering Richmonders every holiday season. ${ }^{556}$ Additionally, Richmond's leading ladies made a regular habit out of driving to visit the various orphanages on or near Christmas Day to help spread cheer amongst the parentless children of the Confederacy and contribute Christmas goodies and gifts to the children. ${ }^{557}$ Sharing the belief that the "children of soldiers fallen in glorious battle or stricken down by fell disease... are the sacred relics, bequeathed by self devoted heroes to a grateful country," Richmond ladies willingly stepped forward to assist these noble orphans. Their fancy carriages and fine visiting apparel doubtless would have made such visits highly conspicuous before the judging eyes of their social inferiors. ${ }^{558}$ The Christmas Eve party of 1864 on behalf of the St. Paul's Church Home orphans was a direct outgrowth of those earlier performances of Christmas charity to benefit the city's orphans.

The ladies' conscious displays of holiday charity unquestionably stemmed from genuine sympathy for the suffering orphans. As Sallie Putnam noted during the Christmas of 1863, "The influence of childhood is magical. The children find their way to our hearts and unloose the purse strings when all other inducements fail." ${ }^{, 559}$ However, during a time of the year when Richmond's most ardent social critics observed every action and appearance by the city elite, such charitable visits certainly assumed a performative quality whereby elite women might showcase their generosity and the fulfillment of their maternal responsibilities before their critics in order to garner more leniency for their personal holiday celebrations. Thus, it is important to

\footnotetext{
556 Richmond Daily Dispatch, December 24, 1861; Richmond Examiner, December 28, 1864, December 31, 1864; Richmond Enquirer, December 31, 1862; Richmond Daily Dispatch, December 28, 1863; Kate Rowland diary, entry for December 26, 1862, Kate Rowland Papers, Civilian and Home Front Collection, Eleanor S, Brockenbrough Library, Museum of the Confederacy (Richmond, VA).

557 Withers, 61; Richmond Daily Dispatch, December 29, 1864.

558 Richmond Enquirer, October 21, 1864.

559 Putnam, 267.
} 
consider the Christmas Eve, 1864 benefit party for the St. Paul's orphanage from multiple angles.

Founded in 1805, the St. Paul's Episcopal Church Home (initially known as the "Female Humane Asylum") was designed specifically to aid and protect female children, long considered the most "vulnerable" members of southern society. The Home was celebrated as Richmond's first and "proudest" charity, with the Richmond Home for Boys established some 41 years later, in 1846, and modeled after its predecessor, the "Female Humane Asylum" ${ }^{560}$ The creation of so many “children's homes” within Richmond appears to reflect Eugene Genovese's arguments about the South's organization around a culture of paternalism that was rooted in southern master-slave relationships, wherein masters were obligated to care for and protect their "childlike" chattel, a substantial percentage of the southern population. ${ }^{561}$

Inspired by the success of the other Homes in Richmond, the newly arrived minister of St. Paul's Church, Reverend Charles Minnegerode, had begun soliciting monetary donations from the Richmond community toward the creation of an "Episcopal Church Home" for orphans and the destitute in the late 1850s. After the war began and the number of orphans and impoverished children started increasing at an alarming rate, Minnegerode officially opened the St. Paul's Church Home in 1861. ${ }^{562}$ In late 1861, the Episcopal Church Home began accepting young girls from outlying areas in Virginia that had been ravaged by recent battles. ${ }^{563}$ By late December 1862, the number of residents at the Home had increased from twenty-five to thirty-

\footnotetext{
560 Duke, Richmond Home for Boys, 2.

561 Genovese, Roll, Jordan, Roll, 6.

562 Elizabeth Wright Weddell, St. Paul's Church, Richmond, Virginia: Its Historic Years and Memorials, 2 vols.; vol. 1 (Richmond: The William Byrd Press, Inc., 1931), 194-195.

563 "Historical Sketch of Richmond's Oldest Charity, the Memorial Home for Girls, 1805-1925," Virginia Historical Society (Richmond, VA), 8.
} 
seven young girls, with twelve girls arriving at the Home following the Battle of Fredericksburg. ${ }^{564}$

In addition to continuing the existing "secular" benevolence of Richmond's charities, Minnegerode reminded Richmonders of the Episcopal Church Home's sacred "responsibility" as well. In converting the Home into an orphanage for the "orphans of the Confederacy," Minnegerode helped to strengthen the bond between religion, secular benevolence, social responsibility, and the politics of wartime southern benevolence at what would become known as "the Church of the Confederacy." He did so in ways that were similar to Confederate President Jefferson Davis's discursive intertwining of religion with the politics of civil war and his use of religion to promote social responsibility and moral order within the Confederacy at large.

Jefferson Davis frequently chose St. Paul's Church as the venue from which to deliver numerous "rallying" speeches to Richmonders about the need for moral behavior, spiritual fasting, sacrifice, and communal aid in order to support of the Confederacy in its darkest hours. Likewise, Minnegerode fervently recruited donations from Richmonders on behalf of the Church Home through combined appeals to religious, social, and patriotic duty. In doing so, Minnegerode ultimately helped to reinforce Richmonders' commitment to the war and to their community, as well as their willingness to sacrifice on the behalf of both in later years-a willingness that is clearly evident in the Christmas 1864 celebration. ${ }^{565}$

In choosing essentially to "dedicate" the 1864 Christmas celebration to the children of St. Paul's Episcopal Church Home, Varina Davis and her peers demonstrated to fellow Richmonders that the Confederate elite were still willing and able to engage in traditionally

564 Weddell, 194.

565 Weddell, 86; Jefferson Davis, "Proclamation by the President for a Day of Fasting, Humiliation and Prayer, With Thanksgiving," January 1, 1865, Saint Paul's Church Record of the Vestry, Virginia Historical Society (Richmond, VA). 
cherished acts of southern benevolence and patronage. With their husbands largely preoccupied by the military challenges facing the Confederate armies during December of 1864, Richmond's elite women assumed nearly full responsibility for this social event. As was noted in previous chapters, the ladies frequently assumed a combined socio-political authority in regularly helping to delineate class divisions and dictate the morals of Richmond society by walking the promenade, theater-going, and by organizing charity concerts, bazaars, and other conspicuous cultural rituals. In a similar fashion, the ladies' claims to sole authority over the Christmas, 1864 were intended to transform the celebration into a powerful projection of elite ladies' social and political power and responsibility. Specifically, the ladies perceived their actions as reflective of their renewed dedication to promoting stability and a moral, ordered society within the Confederate capital during that uneasy Christmas season.

During the first portion of the Christmas Eve party, Varina and several of her female peers supervised the guests, who had gathered around the dining room table and set to work crafting small toys out of scraps of cloth and filling mini-cornucopias with tiny candies and short printed poetic "sentiments" attached to them for each of the orphans. Prior to the event, elite women and their children were enlisted in the task of gathering scraps of old clothing, decorating supplies, and old toys to "rehabilitate" for the orphans. Varina Davis left a detail record of this process:

The little jackets, pieced together out of the cloth remaining when uniforms were turned out by the tailors, were issued to the children of the soldiers... The kindhearted confectioner was interviewed by our committee of managers, and he promised a certain amount of his simpler kinds of candy, which he sold easily at a dollar and a half a pound....The ladies dispersed in anxious squads of toy-hunters, and each one turned over the store of her children's treasures for a contribution to the orphans' [Christmas] tree, my little ones rushed over the great house, looking up their treasures---eyeless dolls, three-legged horses, tops with the upper pegs 
broken off, rubber tops, monkeys with all the squeak gone silent and all the ruck of children's toys that gather in a nursery store. ${ }^{56}$

Varina praised the hard work, creativity, resourcefulness, personal sacrifice of everyone who participated in the "toy hunt," and remarked that, "some small feathered chickens and parrots...were furnished with new tail feathers, lambs minus much of their wool were supplied with a cotton wool substitute, rag dolls were plumped out and recovered with clean cloth, and the young ladies painted their fat faces in bright colors and furnished them with beads for eyes." 567 Additionally, that evening, several of Richmond's upper-class youths came over to the White House to string apples and popcorn for the orphans' Christmas tree; neighbors brought over tiny candle molds with which to make the lights for the tree; and young men carved small cornucopias out of blocks of wood. Varina remembered, "trunks of old things were turned out and snipping of silk and even woolens of bright colors were found to close the tops [of the cornucopias]....The beauty of these home-made things astonished us all, for they looked quite "custom-made." The decorators snacked on homemade ginger snaps and lady cake, and great mirth and joy filled the Confederate White House as children excitedly ran through the halls whispering, "Now I just know this is Christmas." Varina wrote that "in most of the houses in Richmond these same scenes were enacted, certainly in every one of the homes of the managers of the Episcopalian Orphanage," with the First Family’s party leading the way. ${ }^{568}$

Through their elaborate scripting of the Christmas Eve party, Varina and her elite peers sought to set a strong example of benevolence, self-denial, and empathy for fellow Richmonders that might inspire others to embrace these moral tenets of the holiday season over the temptations to engage in potentially threatening, rowdy, or debaucherous behavior.

\footnotetext{
566 Davis, "Christmas in the Confederate White House." 567 Davis, "Christmas in the Confederate White House."

568 Davis, "Christmas in the Confederate White House."
} 
Additionally, this highly performative display of benevolence toward their social inferiors reflects the strong desire of both Varina and her peers to reaffirm the legitimacy and authority of Richmond's leading ladies to remain the social arbiters, moral figureheads, and respectable, motherly caretakers of society. Finally, that the ladies included several young children in the Christmas Eve party, and dedicated the party specifically to the orphans' charity, symbolizes the women's perception of the event as an instructive lesson about elite social responsibility to the upcoming generation of young Richmonders. Furthermore, such instruction helped to educate the Richmond youth about the structure and traditions of the social hierarchy that undergirded daily life and order in the Confederate capital.

Despite their remarkable enthusiasm during this fourth Christmas of the war, few Richmonders could argue that the war-beleaguered Confederacy of late 1864 had not changed significantly from its antebellum and early-war form. James Marten has argued that, for children coming of age between 1861 and 1865, the war was a transformative experience, a "dramatic and exciting, but often tragic and frightening intrusion on their childhoods" that forced "teenagers to grow up quickly" and forced "young women and girls to step out of their customary roles. ${ }^{, 569}$ As is illustrated in the 1864 Christmas celebration, elites used ritualized acts of benevolence as illustrative lessons for their children in the adaptation of traditional cultural practices to fit war-time needs. Such lessons, the elite believed, would help to reinforce cherished social and cultural tenets of Richmond society while illustrating the necessary flexibility of those tenets during the trying war years in maintaining order and stability within the Confederate capital. Thus, the leading ladies' actions during the 1864 Christmas Eve party served as a clear projection both of the proper class delineations within the Confederate capital

569 James Marten, “Days of Misery and Uncertainty: Childhood in Wartime Virginia," in William C. Davis and James I. Robertson, ed., Virginia at War: 1863 (Lexington, Kentucky: The University Press of Kentucky, 2009), 21, 23. 
but also of the important interlocking relationships between the city's various classes. For the women who were present, this particular event reinforced (in their minds) the appropriate power dynamics between the elite and the poor that were so critical to maintaining stability in the Confederate capital by late 1864 .

Varina Davis and her fellow leading ladies were well aware of the importance of maintaining a peaceful, benevolent, yet carefully negotiated give-and-take of power between the elite and the poor to maintaining a peaceful social order in Richmond. In following traditional wartime practices of benevolence and engagement with the broader Richmond community through charitable activities, the women successfully collected "rice, flour, molasses, and tiny pieces of meat, most of them sent to the President's wife anonymously "to be dispersed to the poor." Throughout the war, the First Lady and other prominent Richmond women such as Judith McGuire regularly received gifts of food and other essential items from women of both the upper and lower classes who lived on the fringes of the city or in neighboring counties. The ladies often welcomed these packages not only as gifts of friendship in instances where the recipient knew the sender. On occasions when the sender was a stranger, they often viewed the packages as gifts of appreciation for the ladies' own sacrifices and charitable work on behalf of the wounded and the poor, as well as silent approval of the ladies' public work as social leaders, moral arbiters, and caretakers of the broader Richmond community. Although they occasionally kept several items from the packages for themselves, the ladies often conspicuously delivered the gifts to the hospitals or to various charity fairs and benevolent organizations for the benefit of the city poor. ${ }^{570}$

\footnotetext{
570 Emma Mordecai, entry for June 17, 1864, Emma Mordecai diary, Virginia Historical Society (Richmond, VA); McGuire,
} 247. 
The sending of gifts from the outlying community of struggling yeomen and middling Richmonders seems to illustrate that these outliers were still willing and able to sacrifice for the common good of the Confederate nation, but more so, that they trusted the Confederate elite properly to dispense their donations to the poor. The elite women's selfless expenditures on and personal donations of "luxury goods" such as apples, preservatives, "brandy required for seasoning at one hundred dollars a bottle....cider...[and] suet at a dollar a pound," on behalf of the Church Home likewise reflect the elites' ability and conscious decision to publicly sacrifice their own luxuries for the poor as a reciprocal display of thanks to who had already given up so much to the Confederate cause. ${ }^{571}$

In donating their newly received gifts to the orphans' Christmas, Richmond's leading ladies appropriately conformed to traditional, cultural prescriptions for contractual benevolence that lay at the core of southern antebellum and early-war social relations between elite leaders, masters, and mistresses and their slaves, the middling classes, and the poor. By contrast, northern benevolence was largely characterized by centralized, more impersonal, and more widespread efforts toward the moral reform of society as a whole, and not just one particular locality. Scholars such as Thomas Haskell have argued that a new, and uniquely northern "humanitarian sensibility" dramatically shaped northern concepts of benevolence. The rise and proliferation of industrial capitalism and the expansion of the market economy in the North produced a new appreciation for discipline and self-control, as well as an increased knowledge of the causality between human institutions and moral living. Such awareness of causality wrought a new "cognitive perception" of society and of the responsibilities of the individual to morally uplift not only himself, but also the economic, political and social institutions of his creation. ${ }^{572}$

571 Davis, "Christmas in the Confederate White House."

572 Haskell, "Capitalism and the Humanitarian Sensibility," 111-12, 155, 131, 133-4. 
Interestingly, Varina's ladies went through "redoubled efforts" to procure "eggs and other ingredients" for eggnog that was given not only to the decorators and cooks in return for their sacrifices, but was also given to the Davis family slaves, who were welcomed into the decorating party. In the minds of the Davises, such conspicuous acts of master-slave paternalism conspicuously reaffirmed the First Family's own commitment to the perpetuation of traditional antebellum power dynamics. This clear affirmation of the power dynamics between master and slave also served as a comforting reminder of the familiar, core tenets of antebellum social life that unified the Confederate elite around a shared identity, prowess, and cultural authority for which it was worth both fighting and sacrificing. ${ }^{573}$

The gathering of the dinner supplies, the dispersal of the eggnog, and the preparation of the feast for the orphans reflects elite ladies' flexible and enduring use of a culture of social rituals to try to perpetuate their own social rule amidst the constant challenges in the late-war period. For the upper classes, the mutual participation of the elite, the outlying middling classes, slaves, and the orphan children in the Christmas event suggested that the upper and lower classes had continued to understand and support each others' needs and roles within Richmond's hierarchical society. However, the importance that Varina placed upon indulging her elite peers in several glasses of eggnog that Christmas Eve highlights the symbolic nature of such a gesture to placate the sacrificing elites who had been used to the more lavish Christmas celebrations of previous years. The gesture was a small, but comforting display of gratitude toward her peers for their dedication to this event.

For both Varina and her guests, the First Lady's eggnog toasts with her peers also symbolized a silent affirmation of the continued power and privilege of the elites who were

573 Geertz, qtd. in Burke, 93-96. 
indeed able and entitled to enjoy sipping glasses of eggnog that winter as they worked to design an elaborate feast for the city's orphans. The toasts celebrated the ladies' engagement in charity for the poor, yet helped them maintain an appropriate social distance from the poor by allowing them to indulge in the social privileges of elite ladyship. The toasts therefore played an integral role in the ladies' execution of their social responsibilities and in providing a much needed, comforting reminder of their social privilege and perceived authority over those for whom they were sacrificing. ${ }^{574}$

In giving eggnog to the family slaves, the Davises also sought to reaffirm their power over their labor force. Admittedly, the Davises may have believed that the bestowal of such a treat was merely in accordance with the continuation of southern Christmas traditions between master and slave, and that it truly was a kind act of paternalistic benevolence. ${ }^{575}$ However, as was noted earlier, southern slave owners often grew anxious in anticipation of how their slaves might "celebrate" the Christmas holiday if they were unhappy or frustrated with their masters. Rowdy behavior, rebellion and acts of resistance long had characterized Christmas celebrations among the lower classes and African Americans. More, importantly, the Davises were well aware that increasingly larger numbers of slaves were running away to the protection of the Union army, serving as spies for Union officers, and were rebelling against their masters and mistresses. Having already lost several of their own slaves to desertion, and having been robbed by multiple domestic slaves over the course of the war, it is likely that the Davises, like other slaveholders, were seeking to quell or thwart thoughts of such behavior this holiday season through their calculated indulgences of their slaves. ${ }^{576}$

574 Pickett, Across My Path, 13; Harrison, 129, 170.

575 For a fuller examination of the influence of "paternalism" upon slaveholders, see Stowe, Power and Intimacy in the Old South, and Genovese, Fatal Self-Deception.

576 Nissenbaum, 273; Cashin, 126, 143. 
Thus, the First Family's elite-sponsored Christmas celebration served both as a "performance" of elite leadership and as a hopeful social-ordering ritual for both slaves and the poor. The eagerness and excitement with which Richmonders, and especially those at the "decoration party," approached the event indicates the participants' appreciation for the enormous symbolic and moral significance of the celebration for the larger Richmond community, as well as their dedication to and willingness to participate in the aid, protection, and survival of such a community. ${ }^{577}$ To the party organizers, outlying Richmonders' reciprocal displays of perceived gratitude and allegiance to their elite leaders also appeared to suggest that those outlying Richmonders, as recipients of year-round elite patronage and guardianship, were still loyally committed to holding up their end of the contractual social relationship between themselves and their elite patrons. Despite the desperate state of the Confederacy that Christmas, Virginians from throughout the state sent small gifts to the First Family. The President himself received "a pair of chamois-skin riding gauntlets exquisitely embroidered on the back with his monogram in red and white silk, made, as the giver wrote, under the guns of Fortress Monroe late at night for fear of discovery." Mrs. Davis received "six cakes of delicious soap, made from the grease of a ham boiled for a family at Farmville, a skein of exquisitely fine gray linen thread spun at home, a pincushion of some plain brown cotton material made by some poor woman and stuffed with wool from her pet sheep, and a little baby hat plaited by the orphans and presented by the industrious little pair who sewed the straw together."578

Following Christmas breakfast, the First Family and their peers attended a church service led by Reverend Minnegerode (interestingly, noted as the "creator of the first American Christmas tree") at St. Paul's Church. The First Family showed its respect for the sanctity of the

\footnotetext{
577 Wickberg, 664.

${ }^{578}$ Davis, "Christmas in the Confederate White House."
} 
holiday by walking to church rather than using the family carriage. ${ }^{579}$ Minnegerode "preached a sermon on Christian love, the introit was sung by a beautiful young society woman and the angels might have joyfully listened." ${ }^{580}$ Sallie Brock Putnam lauded the fact that

On this day, not the knee alone, but the heart was bowed, and fervent prayers were offered that no more should the Christmas sun dawn on our land deluged in blood, but that when Christmas came next the sun of peace might shed its light on hears now breaking under the cruel oppression of remorseless war. The exercises at church were all that was left to remind us of Christmas as of yore. ${ }^{581}$

The ladies' attendance at the St. Paul's Christmas Day service in 1864 was deeply imbued with powerful socio-political significance and lent further cultural authority to their larger Christmas commemoration. Throughout the war, Confederate leaders had relied so heavily on St. Paul's Church as a venue at which to gather the citizens of Richmond for political speeches, "rallies," news from the battlefield, pleas for charity for soldiers and their families, and, of course, for religious ceremonies during the highest and lowest points of Confederate morale, that the church had been deemed the unofficial "Church of the Confederacy." Upperclass Richmond women frequently gathered in the lecture room of the church for "sewing circles" to benefit soldiers on the battlefield and the poor on the home front, thus claiming the church as the purview of the elite. ${ }^{582}$

Women also gathered in the church to roll bandages for the wounded, collect cushions from the pews to send to local hospitals, and gather Bibles for the Virginia Bible Society to dispense to the poor and the despondent, as well as to the soldiers. Outlying Virginians who sought to help the struggling soldiers and civilians in the Richmond area often used St. Paul's Church as a mailing address to which to send supplies, foodstuffs, and bandages. ${ }^{583}$ Numerous

\footnotetext{
${ }^{579}$ Davis, "Christmas in the Confederate White House."

580 Davis, "Christmas in the Confederate White House."

581 Putnam, 269.

582 St. Paul's Church Record of the Vestry, Virginia Historical Society (Richmond, VA).

583 Weddell, 179, 201, 185.
} 
civilian and soldier relief societies established a temporary "office" in St. Paul's to which local residents could go for aid and support, transforming St. Paul's into both a physical and symbolic center of conspicuous charity. ${ }^{584}$

Additionally, the Church witnessed the wartime weddings of numerous Confederate officers and Richmond belles, such as the January 1865 wedding of General John Pegram and Hetty Cary. The Church also became a sacred Confederate icon through its hosting of the numerous military funerals of the Confederacy's most beloved fallen heroes. ${ }^{585}$ President Davis himself gave the church special patriotic significance by choosing to be confirmed there in May 1862 and through his regular attendance at Sunday services. ${ }^{586}$ Davis continued to vest the Confederacy with sacred authority and a divine ordination from the pulpit of St. Paul's when he proclaimed days for national fasting and pleaded for sacrifice and devotion to the Confederate cause. Davis's proclamations, paired with his pleas to southerners for sacrifice and loyalty to the Confederate administration reflects elites' continued use of St. Paul's as a venue both to display elite political force and to try to garner the deference of the "masses" necessary to rule successfully. The lady organizers of the Christmas, 1864 church service and orphans' party thus chose wisely in selecting St. Paul's, rich in its social, political, and moral significance, as the "theater" in which to execute their important social performance that Christmas Day.

Confederates' reliance on religion to help them through the travails of war was evident in Richmonders' increasing attendance at St. Paul's over the course of the war. Reverend Minnegerode, Richmonders wrote, "filled this venerable building with a flaming Glory of Devotion to a Great Cause which can never die." One member of the congregation wrote that

\footnotetext{
584 Saint Paul's Church Record of the Vestry, Virginia Historical Society (Richmond, VA).

585 St. Paul's Church Record of the Vestry, Virginia Historical Society (Richmond, VA).

586 Weddell, 162.
} 
"the congregation of St. Paul's was close to the heart of the Confederacy....their hope is full of Immortality." 587 Another Richmonder commented that "spiritual life is unabated, services well attended...despite wars and rumors of war, of the ever-present spectre of hunger, of vigils among the sick and wounded and dying, the faith of the people grew ever stronger, and St. Paul's continued as a beacon of light across troubled waters." 588 With its aura of "dignity and beauty," St. Paul's embodied the spirit of the Confederate nation. Additionally, the frequent Sunday service attendance of some of the Confederacy's most cherished leaders, generals, and prominent Richmond families imbued the Church with special nationalistic significance for the Confederacy. ${ }^{589}$ President Davis's March 1865, proclamation for another "day of fasting, humiliation and prayer with Thanksgiving" for the success of the Confederacy reveals how heavily Davis and other Confederate leaders relied upon religion and the church to guide the Confederacy to victory by the late-war period. In that proclamation, Davis pleaded to his southern countrymen and women,

Let the hearts of our people turn contritely and trustingly unto God, let us recognize in His chastening hand the correction of a Father and submissively pray that the trials and suffering which have so long borne heavily upon us may be turned away by His merciful love, that His sustaining grace be to our people and His divine wisdom be imparted to our rulers that the Lord of Hosts will be with our armies and fight for us against our enemies and that He will graciously take our cause into His own hand and mercifully establish for us a lasting, just and honorable peace and independence. ${ }^{590}$

Throughout the war, elites' highly conspicuous presence at Christmas church services both reflected a sincere desire on behalf of leading Richmonders to celebrate the holiday with appropriate solemnity and spirituality and served as a ritualized performance of shared empathy

\footnotetext{
587 “Confederate Memorial in St. Paul's Church,” October, 1960, St. Paul's Church files, Virginia Historical Society (Richmond, VA); Weddell, 194-195.

588 Weddell, 233.

589 Weddell, 24-5.

590 Saint Paul's Church Record of the Vestry, Virginia Historical Society (Richmond, VA).
} 
and concern for the community with fellow Richmonders who were present at such services. It is no wonder, then, that upon consulting with the Episcopal Church Home advisory board, Varina Davis, a devoted member of the St. Paul's congregation, and her peers decided to hold the 1864 Christmas celebration in the basement of St. Paul's Church.

The venue for the celebration reinforced the elites' commitment to a religiously-backed moral order in the city and their reliance upon religion to help confront the complex social and political challenges of war. In choosing St. Paul's as the official venue for the Christmas celebration, the elites strove not only to help lighten the hearts of and "rally" Richmond's youth and other despondent residents and refugees of the city to renew their faith in the Confederate cause through religion. Their choice also reflects a desire to make the Christmas Day event as conspicuous as possible by hosting it within the official "Church of the Confederacy." Perhaps aware of the more insular nature of the other two elements of that Christmas celebration, the ladies' selection of St. Paul's Church helped to refocus the public spotlight on some of the most honorable and most socially and politically important actions of the female elite during the twoday celebration. The ladies were well aware that such public projection was essential to insuring the success of, and positive reaction to, this special 1864 Christmas celebration.

After the service, the ladies proceeded with the orphans' Christmas party through yet another set of carefully crafted, highly symbolic interactions with the children. Upon leading the orphans into the basement of the church for the afternoon feast, the opening of gifts, and a viewing of the special "children's tree" that the elites had decorated the night before, the First Family paused and opened the celebration with a "hymn and solemn prayer" to remind the eager orphans of the sanctity of the occasion. ${ }^{591}$ The festivities that ensued were part of a traditional celebration of the Christmas holiday and were a welcome relief from the miseries and privations 
of war. However, for the female organizers, the revelries possessed the (admittedly unrealistic) potential to help reinvigorate the broader spirit and optimism of the Confederate capital, as well as to inspire others toward good behavior that holiday by fostering appreciation for a moral, peaceful, and orderly Christmas celebration.

The leading ladies paternalistically bestowed upon the eager orphans the gifts that they had prepared the night before. Varina recalled that "the different gradations from joy to ecstasy which illuminated their faces was 'worth two years of peaceful life' to see." In perhaps the most symbolic and (perhaps subconsciously) "performative" act of elite Confederate patronage, President Davis himself became so excited that he personally seized several of the gifts and enthusiastically began placing them in the "outstretched hands" of the "Confederacy's orphans." In a clear example of contractual master-slave patronage, the First Family also gave small gifts to their slaves who, Varina recalled, "one after another 'caught' us by wishing us a merry Christmas before we could say it to them, which gave them a right to a gift. Of course there was a present for every one, small though it might be." 592 The First Family then crowned the "most orderly girl among the orphans" as the 'honor girl' for that Christmas. The bestowal of this prize appears to have been a conscious, symbolic effort by the elites to inculcate and reinforce within the poor children of the celebration a reverence for the cherished southern values of moral "ladyship." This ritual also celebrated what the ladies considered to be the successful adaptation of those cultural values of respectable femininity to the needs of a beleaguered Confederate nation.

Following the Christmas service and the party for the orphans, Richmond's leading ladies quickly dispersed from the church and made their way back to their homes to get ready for a

592 Davis, “Christmas in the Confederate White House." 
starvation ball that evening, the grand conclusion to their carefully sculpted Christmas

celebration. Traditionally, after each Christmas service of the war, an array of feasts, parties, and dances similar to those mentioned in chapters one and two quickly commenced, revealing the elites' prerogatives toward festive and refined enjoyment of the holidays that was befitting their class. These festivities also served as a pleasant reward for their sacrificing of items toward charity in the prior days and their devoting a large portion of their Christmas Day toward prayer and empathetic gatherings with the city poor.

Traditionally, while making their way back from Christmas service, prominent ladies such as Constance Cary had frequently enjoyed promenading through the streets with baskets of fresh holly, greeting friends with warm smiles and proudly showcasing their elegant holiday dresses before the public. ${ }^{593}$ This Christmas promenade undoubtedly occurred on Christmas Day of 1864. True to the traditions of the Richmond promenade discussed in chapter three, this festive display of wealth, respectability, and authority served not only to help set the appropriate tone for the behavior and celebrations of the day; it also prominently highlighted the Christmas Day activities of the elite — church-going, engagement with the community, charitable work, and attendance at exclusive social gatherings — that defined southern ladyship and might hopefully inspire others to emulate such moral behavior. Simultaneously, the elites relied upon the Christmas promenade to re-impress upon the community the entitlements of the leading ladies to the cultural power and authority of social leadership.

On Christmas night, 1864, Richmond's leading ladies flocked to a prominent city mansion for a special "starvation ball." The women's participation in this final element of the Christmas event was, perhaps, the clearest example of elites'—and especially elite women'sengagement in a ritualistic holiday performance of the simultaneous denial and indulgence

\footnotetext{
593 Harrison, 167.
} 
necessary to perpetuate both the social power of the leading ladies and the traditional social order of the war-torn city. As discussed in previous chapters, starvation parties began in Richmond during 1863 upon Constance Cary's creation of a "Starvation Club of Richmond." Instituted under the auspices of providing a necessary, uplifting social club and entertainments for the city's depressed and anxious elite, as well as offering morale-boosting parties and dances for Confederate officers stationed in and around Richmond, the club quickly became known for its prestigious members and its frequent parties. ${ }^{594}$ At the meetings of the Starvation Club, attendees contributed miniscule amounts of money toward the musical entertainment of the evening; however, "all refreshments were strictly forbidden," and the only expense paid by the host was that to cover the wood for the fire. The hostesses regularly invited soldiers to attend their parties, and local belles relished the attention of dashing young officers. Sallie Putnam noted that "these entertainments were varied occasionally by the performance of plays and tableaux vivants, in which considerable talent was exhibited in the histrionic art by some of the quickly created actors and actresses. This introduction of plays and tableaux added an exquisitely charming variety to the winter's social enjoyment in the rebel capital." ${ }^{, 55}$

As was noted earlier, LaSalle Corbell Pickett, among other prominent young female Richmonders, relied upon these social engagements to escape temporarily from the hardships of war and to boost their collective morale; to refresh and relax their anxious minds in order to improve their effectiveness as political and social leaders; and to help remind the Confederacy's leading gentlemen and ladies that the Confederate spirit not only was still alive, but that it also was worth their loyalty and sacrifice. Not all Richmonders felt so confident about the endurance

\footnotetext{
594 Edward M. Alfriend, "Social Life in Richmond During the War," in ed. R. A. Brock, Southern Historical Society Papers, 19 (Richmond, VA: Southern Historical Society, 1891), 380-383; see also, Margaret Louborough and James H. Johnston, The Recollections of Margaret Cabell Brown Loughborough: A Southern Woman's Memories of -Richmond, VA and Washington, $D C$ in the Civil War (New York: The Rowman and Littlefield Publishing Group, 2010), 72.

595 Putnam, 270; Harrison, 150.
} 
and fate of the Confederate nation throughout the war, thereby making it a necessity that the starvation parties foster such confidence on a routine basis.

For instance, as early as July of 1862, Varina confessed in a letter to her husband that she remained "still pessimistic about the South;" she felt intimidated by the North's greater resources, habits of discipline, and perseverance, and declared that "if the South should fail, it would be God's decree." 596 In the late fall of 1864, Varina confided to Mary Chesnut, "I confess I do not snuff success 'in every passing breeze' but I am so tired-hoping, fearing, and being disappointed." She proceeded to stress to her friend her sincere efforts "not to be disconsolate, even though thieves break through and steal." Nevertheless, she admitted that she had a "blind kind of prognostics of victory for us, but somehow I am not cheered."597 In early 1865, Varina yet again revealed her pessimism for the South to her friend, General Preston. She wrote to the General of how she, like many women of the lower classes who had suffered immensely from the physical and emotional toil of war, now criticized southern men for entering the war. She confessed that she no longer believed in popular sovereignty or states rights, but "only in the guarantee of republican society." The war had been a mistake, Varina wrote, but a mistake that the South "had to try.",598

Nevertheless, in spite of her occasional personal doubts about the Confederacy, Varina dedicated herself to the Confederate cause and worked even harder to squelch her doubts by redoubling her efforts to maintain (even if through mere "performance") the familiar and cherished tenets of southern culture for which the Confederacy had gone to war. The perpetuation of exclusive balls such as the starvation parties helped to elevate her spirits, especially during the later years of the war. Mary Chesnut wrote of the necessity of such "tame"

596 Cashin, 129.

597 Chesnut, 674.

598 Cashin, 156. 
festivities, and commented that "hope and fear are both gone and it is distraction or death with us. I do not see how sadness or despondency would help us."599 Additionally, as Phoebe Pember noted, "young men advocated this [festive] state of affairs, arguing that after the fatigues and dangers of a campaign in the field, some relaxation was necessary on their visits to the capital. $" 600$

Although refreshments at the starvation parties were essentially non-existent, the city's leading ladies often attended the elite parties dressed in their finest ball gowns and accessories both from the pre-war days and from packages that their men had acquired for them through the blockade. ${ }^{601}$ Male attendees came dressed in distinguished eveningwear or their military uniforms. The conscious decision to dress up for the occasion reflects elites' efforts to display (for each other, and for any onlookers from the city streets), their power and position at the top of the southern social hierarchy. In the minds of the party-goers, such events were critical to reaffirming their "right" to continue ruling over the lower classes. ${ }^{602}$ Part of this "right" to rule derived from elites' perceptions that they were sharing in a "sensibility of suffering" with the lower classes by sacrificing some of their own traditional material luxuries. In doing so, the elite hoped to acquire the moral sanctity and deference of the lower classes to rule by reaffirming for them their empathetic understanding of and "alliance" with the poor.

\footnotetext{
599 George Greene Shackelford, George Wythe Randolph and the Confederate Elite (Athens, GA: University of Georgia Press, 1988), 89-91.

600 Shackelford, 77.

601 Although several Lost Cause era diarists and social commentators such as T.C. DeLeon noted that the female attendees were merely "calico-clad" or appropriately "dressed down" for such occasions, the contemporary writings of the female capital elite and some of the regular starvation party attendees such as LaSalle Corbell Pickett, Virginia Clay, Varina Davis, Mary Chesnut, and Constance Cary intimate that, just like other elite parties, these increasingly "formal" and "official" gatherings ultimately required fancier dress attire for both men and women, and thus likewise placed additional pressure on the ladies for constant renewals of their distinguished wardrobes. (See specifically, Harrison, 150 and Davis, "Christmas in the Confederate White House").

602 Clifford Geertz, qtd in Burke, 94-95.
} 
However, another part of the elites' right to rule derived from what Karen Haltunnen calls the "sentimental" culture of nineteenth-century America, in which the donning of classspecific dress enabled one to reveal his or her true social identity. In this instance, elites wore their finest outfits to the starvation party to "demonstrate their gentility" and prove that they were still, indeed, "true ladies and gentlemen deserving of [their] higher social place." Additionally, by dressing up, the elites distinguished themselves from those lower classes of the Confederacy for whom they had sacrificed the accoutrements of upper-class status on Christmas Day. Though the elites took pride and pleasure in caring for and associating with the lower classes during the special Christmas celebration, they used the evening's starvation party as a dramatic display through which they could reaffirm, among themselves, their distinction from those lower classes, and thus pledge to one another their "mutuality of moral support" as members of the ruling elite. ${ }^{603}$

Although the starvation parties occurred year-round in the Confederate capital, they grew especially popular during the holiday season and the ensuing winters of 1863 and 1864 .

However, like other festive gatherings and parties, these holiday starvation balls quickly became the target of the ladies' sharp-tongued critics-husbands, newspaper editors, members of the general public, and even some of their own peers - who regarded elite proclivities toward partying, however scaled back, to be wholly inappropriate during the gravest moments of war. Such critics scorned the efforts of the elite women to perpetuate what was still, in their own minds, a selfish culture of extravagance that they feared would only undermine the Confederacy just when the nation required elite sacrifice the most.

A conflicted Mary Magill both sympathized with and yet looked down upon her fellow ladies for indulgence in such revelry during some of the darkest periods of the war. Magill

603 Haltunnen, xvii, 194; DeLeon, 396. 
admired the war-weary women for their attempts to resist over-indulgence during these parties, noting,

It was curious how the necessary economy of the times came in even with this element of society, for supper-less balls and tea-less parties were the order of the day. Young people would meet together and dance wildly the night through, without any refreshments to support them in the exhausting exercise. Soldiers in from the field got furloughs to engage in the gaiety. ${ }^{604}$

However, she also wrote critically of the "cold-heartedness" that such frequent parties instilled in the city's leading ladies and gentlemen:

It is a strange and noticeable lead we turn in the study of human nature, that constant familiarity with scenes of suffering renders the heart callous to them. It is so in great epidemics where men and women laugh and dance upon the brink of their own graves; and it is always the case in times of war that there is a recklessness of mirth and enjoyment, as if the mind sought escape from the present by living in a continual state of excitement, whose charm is that it blinds the mind's eye and hardens the heart to the realities of life....The soldiers had no shame either. ${ }^{605}$

Women such as Phoebe Yates Pember also wrote disapprovingly of these elite parties, scoffing at the contrast that she still perceived between Varina's comparatively luxurious living conditions and the horrors and deprivations that she encountered in the hospitals that winter. Pember scornfully remarked in her journal that, while she was bearing the emotional, social and physical burdens of hospital work as the Chief Matron at an otherwise male-dominated hospital, the First Lady was "growing very fine" and sending out advertisements for a new housekeeper at the Executive Mansion. She also indirectly criticized the lavish lifestyle of Davis and her peers in February 1864, subtly implying that it would be the fault of the Confederacy's "high rollers" if the South should lose the war. "If Spartan austerity is to win our independence," she wrote, we are a lost nation. I do not like the signs and fear the writing on the wall might in time come to 
us." ${ }^{606}$ During the winter of 1864 , Pember grew increasingly bitter about the "selfish lifestyles" which the so-called "starvation partiers" appeared to be living in the city. Pember wrote in her hospital diary,

The city is unusually gay this winter...with parties, private theatricals, and tableaux. Wise and thoughtful men disapproved only of this mad gayety. There was certainly a painful discrepancy between the excitement of dancing and the rumble of ambulances that could be heard in the momentary lull of the music carrying the wounded to different hospitals...To thinking people, this recklessness was ominous, and by February, 1865, it began to be felt by them that all was not as safe as was supposed to be. ${ }^{607}$

Judith McGuire also wrote ashamedly of the upper class's continued indulgence in gourmet food during non-starvation events in the late-war period, the elites' wardrobe finery, and extravagant parties as a whole_-whether they served food or not. She balked at the fact that, in the late-war years, the Confederate army's situation was so desperate that “country people were sending in [to the Richmond hospitals] all things, which they cannot spare, but do so anyway," while her peers went on dancing and partying to the very end. ${ }^{608}$ Mrs. Roger Pryor, wife of a prominent General and fire-eating secessionist newspaper editor, scoffed at her peers' complaints about the decreased availability of luxuries such as barrels of sorghum, which had been sent into the city by outlying friends. Mrs. Pryor fumed, "why, in these days with our country in peril, I am grateful when I am able to get a pitcher of sorghum, and I teach my children to thank God for it!" 609

However, despite these caustic remarks from their peers, and despite their own lip service regarding the necessity of true starvation parties, some leading ladies such as Mrs. Clay "refused to let high costs and other problems of living in the Confederate capital prevent her from

\footnotetext{
606 Phoebe Yates Pember, A Southern Woman's Story: Life in Confederate Richmond, including unpublished letters from the Chimborazo Hospital, ed. Bell Irvin Wiley (Jackson, TN: McCowat-Mercer Press, Inc., 1959), 154, 185.

607 Pember, ed. Wiley, 77.

608 McGuire, 118.

${ }^{609}$ Clay-Clopton, 179.
} 
enjoying one "final fling." Mrs. Clay was admittedly more reckless in her spending than many of her elite peers. While a temporary refugee in Georgia during the last months of the war, Mrs. Clay continuously sent letters to her husband, pleading to him to send her extravagances such as French corsets, fashion books, dresses, bonnets, hankies and furs, while also repeatedly turning down her peers' requests for her aid in knitting socks and rolling bandages for the wounded in the local hospitals. ${ }^{610}$

It is no wonder, then, that to soldiers and officers, such as native Richmonder, Colonel William Pegram, who was struggling for his survival out on the battlefield, it seemed that Richmond "must be getting fearfully corrupt" with its patronizing starvation parties and other balls. Pegram believed that the "gayety and corruption" of the city was the fault of "parvenus and newcomers." According to historian Peter Carmichael, Pegram believed that these intruders “challenged the traditional class structure of Southern society...[and] jeopardized the South's special relationship with God because they had succumbed to greed and profiteerism." Pegram also feared that God "will not favor us [the Confederacy]" if such moral degradation continued in the Confederate capital. Pegram was "disgusted" that "one half of a community reviled in dance \& festivals, when the other half are mourning for their dead friends." Worse yet, many Confederate soldiers believed that some self-centered civilians actually had forsaken "the cause" altogether and were actively working to undermine it. According to Carmichael, "[b]y 1863 Southern soldiers increasingly held to the conviction that large elements of the civilian population disparaged the army's sacrifices, were concerned above all with prospering from the war, and encouraged the faithful to abandon the Confederate cause." These same soldiers also

\footnotetext{
610 Carol Bleser and Frederick Heath, "The Clays of Alabama: The Impact of the Civil War on a Southern Marriage," in Carol Bleser, ed., In Joy and in Sorrow: Women, Family and Marriage in the Victorian South, 1830-190 (New York: Oxford University Press, 1992), 144-146.
} 
were convinced that, even if there were some civilians who were not consciously striving to undermine the Confederate cause, those civilians' selfish behavior would still result in the sure destruction of the South's "moral fabric" and prevent the Confederacy from achieving ultimate victory. Stephen Dodson Ramseur agreed with Pegram, and wrote that the army was "sound" but that he feared the southern civilians might "condemn us to dying in this cause." 611

In one such outburst against the "extravagance" of Richmond's women, one hungry wounded soldier at Richmond's Chimborazo hospital angrily demanded a serving of pickles with his dinner. Hospital matron Phoebe Pember replied that such "luxuries" were no longer available at Chimborazo. Immediately, the soldier snapped at Pember, "Perhaps we would have more pickles if you had fewer new dresses!" 612

Nevertheless, elite women used starvation parties as a way simultaneously to enjoy the privileges of their social position and attempt to reaffirm their place at the top of Richmond's social hierarchy by appeasing both the poor and their critics with conspicuous demonstrations of self-denial, suffering, and empathy with the poor. For the elite, such demonstrations of selfdenial also served a political purpose, as the elite firmly believed that these unique parties provided a model of patriotic sacrifice to which other, more selfish or more despondent individuals might turn for moral inspiration.

Knowing that the ladies expressed genuine concern for and pledged continuous relief toward the sufferings of their social inferiors throughout the war, it would be unfair to suggest that elite women had altogether forsaken the needs and demands of the poor and the wounded by the end of the war due to an all-consuming selfishness or proclivity for callous partying. ${ }^{613}$

611 Peter Carmichael, Lee's Young Artillerist: William R.J. Pegram (Charlottesville, VA: The University Press of Virginia, 1995), 111-112.

612 Pember, ed. Wiley, 75.

613 See, Rable, x, 106, 200; Faust, 234, 244. 
Rather, the starvation parties illuminate some of the problematic blind spots in elite women's perceptions of their social authority and their belief that a careful balance of calculated selfindulgences with conspicuous self-denials might help to solve some of the social ills of the capital. Such blind spots made the ladies unable to understand how some of their peers and the poor might interpret their starvation parties differently than they did, and how such different interpretations might lead to their own, dangerous alienation and their critics' disaffection with the ruling class.

Instead, frequent attendees such as T.C. DeLeon often praised these parties as "unique assemblies...for mutual moral support," a way to recreate the comforting "wraiths and manes of aforetime splendors," and to cultivate anew the "high courtliness and refinement" of a respectable and moral society. ${ }^{614}$ In turn, Richmond's leading ladies also justified the partiesboth to themselves and to others - as important inculcators of morale for Richmond's social and political leaders, as well as an affirmation of the privileges, authority, and moral living of the elites to whose "respectability" all others should seek to aspire. Through such performances, elites sought to reclaim moral order over society and further help appease and stabilize the precarious social order of the Confederate capital. In dressing in their best for the parties, making conspicuous grand entrances at the gatherings, and dancing the evening away behind the exclusive walls of the city's most distinguished residents, Richmond's leading ladies certainly would have made an impressive social statement to the observing public, but one which they wholly justified through their sacrifice of food, water, and professional entertainment at the parties. Unfortunately, as revealed through the commentary of their many social critics, even these starvation balls worked at cross purposes with the ladies' lofty intentions, and ultimately

\footnotetext{
614 DeLeon, 396.
} 
served far more as a comforting and uplifting ritual for the elite themselves than they served as an effective means of garnering the support and the trust of the general public.

However, although such "sacrifices" may at first glance seem trivial against the backdrop of the war's exaction of enormous sufferings from the poor on a daily basis, these dramatic social performances allow a critical portal into the worldviews and social perceptions of Richmond's leading ladies near the end of the war. Despite the continued sharp criticisms of certain individuals (and contemporary historians) about the distastefulness of such parties and the sinfulness of "dancing on the grave's edge," the fact that the ladies continued these starvation parties right through the winter of 1864-1865 brings to light their personal understanding of the social needs of and perceived cures for Richmond society amidst the misery and uncertainty of the late war period. The ladies' persistence in perpetuating these starvation parties right up through the turbulent final months of the war also speaks to an impressive determination by the elites to keep on striving to preserve a sense of order and way of life that soldiers on the battlefield ultimately could not. While the ladies' relentless social critics still could not see past what they viewed as the selfish and overly elaborate starvation balls such as that which occurred on Christmas night, 1864, the elites continued to believe that they were merely acting accordingly to their class position. Furthermore, they believed, their overwhelming display of benevolence and empathy towards their social inferiors entitled them to a Christmas night retreat for their own celebrations.

The audience for the majority of the 1864 Christmas celebration was, in reality, significantly smaller than the organizers perhaps imagined it to be. The exclusive nature of most of the events, both in terms of space and participation, prevented the celebration from casting the broad public shadow that the organizers needed to achieve any widespread influence upon 
Richmond society as a whole that Christmas. It is unclear whether the organizers were cognizant of this fact or whether they had convinced themselves of the far-reaching, symbolic impact of their actions. Nevertheless, for the select few involved in the celebration, the event seems to have left a lasting memory. Alice West Allen, an eleven-year old girl living in the Virginia Piedmont region during the last Confederate Christmas, wrote fondly of her "refugee Christmas" in Richmond that winter. Fearing that their home soon would fall behind the enemy lines of General Sheridan's army, the Allens sent young Alice and her two brothers to the safety of the Confederate capital to live with extended relatives. The children were "wild with excitement" for going to the "big city," and delighted in being invited to the First Family's Christmas celebration by a friend of their mother's. In Richmond, they spent the afternoon playing hideand-seek with the Davis children, partaking in the Christmas feast, and reveling in the beauty of the Davises' elegant Christmas tree. ${ }^{615}$

For Alice Allen and her brothers, as well as for the many orphans and poor Richmonders who partook in or benefitted from the Christmas benevolence of the elites, the ladies had, in the words of young Clara Lynn Minor, "come to the rescue, as they had often done before." Though some of their peers, husbands, and soldiers in the field had failed to recognize it, the female elite had undoubtedly become true "mothers of invention." Furthermore, in the minds of the party's organizers, these leading ladies had proved themselves steadfastly devoted to the maintenance of traditional southern cultural tenets and a moral, social order through their conspicuous performances of authoritative patronage, contractual benevolence, and respectability. For these women, their perpetuation of such practices through the Christmas of

\footnotetext{
615 Alice West Allen, "The Tree Was a Lovely Holly," in Katharine M. Jones, Ladies of Richmond, Confederate Capital (New York: Bobbs-Merrill Company, Inc., 1962), 245-246. 616 Clara Lynn Minor, “A Novel Christmas Tree," 1900, vertical files, Christmas file, Eleanor S. Brockenbrough Library, Museum of the Confederacy (Richmond, VA).
} 
1864 had allowed them to play what they perceived as an increasingly active social and political role in the defense of their nation by caring for the under-classes, actively trying to maintain their morale, pride and social standing within the Richmond hierarchy, and continuously seeking to bring stability and order to a society teetering on the verge of destruction at the violent hands of an invasive and all-consuming civil war.

Historians such as George Rable, Drew Faust, and Jon Wakelyn have argued that elite southern women placed personal desires for material and emotional comfort above the Confederate cause, engaged in selfish habits of extravagant indulgence which consciously served to undermine the Confederacy, and were, in the end, "Confederates against the Confederacy." 617 However, this analysis of the "last Confederate Christmas" reveals a broader and deeper significance behind this intriguing celebration and its related festivities. Indeed, such an analysis illuminates the celebration as a carefully crafted ritual that elite women imbued with enormous social, political, and cultural significance and potential. In quickly condemning the actions and intentions of Richmond's leading ladies, many historians have placed the importance of the potentially causal relationships between the female elite and the poor over the significance of the worldviews and perceptions of the women themselves. Such an approach to the study of the leading ladies' social events and interactions also prevents us from understanding the specific modes of thinking of which the female elite were capable. Rather, a more culturally focused analysis of the 1864 Christmas celebration in the Confederate capital opens a critical portal through which we are able better to comprehend the potential consciousness of Richmond's leading ladies and their own interpretation of the significance of their actions.

\footnotetext{
617 See Rable, Civil Wars; Faust, Mothers of Invention; Drew Gilpin Faust, "Altars of Sacrifice: Confederate Women and the Narratives of War," The Journal of American History 66, no. 4 (March, 1990): 1200-1228; Jon L. Wakelyn, Confederates Against the Confederacy: Essays on Leadership and Loyalty, (Westport, CT: Praeger Publishers, 2002).
} 
Through such an analysis, the "last Confederate Christmas" produces an understanding of the social perceptions (however naïve or idealistic they may seem) of the leading ladies that strongly influenced their controversial actions. In turn, the 1864 Christmas celebration emerges as a remarkable microcosm of elite women's loyalty to a tradition of social rituals and cultural scripts as a means to reaffirm their contested identities as Confederate ladies. This unique event also richly illustrates how those women used carefully crafted social rituals as opportunities to wield the social and moral authority affiliated with ladyship in ways that, they believed, might help to help stabilize the social order of a society torn by civil war. Hardly static, these rituals evolved throughout the war in response to the war's myriad social, political, and economic challenges to accommodate both the needs and desires of the ruling class.

However mistaken the ladies ultimately might have been in their estimation of the celebration's broader influence, the elaborate 1864 Christmas event provided elites with the comforting belief in both lower and upper class allegiance to a common culture of social performance and rigid hierarchy during the most demanding and stressful period of the Civil War. Additionally, in the minds of the female organizers, the event invested the ladies with the powerful ability to uphold cherished southern traditions, rituals, and systems of power. Modeled after antebellum southern ideals, reflecting the evolution of those ideals into a "Confederate Richmond" culture, and adapted to the demands of war, the 1864 Christmas celebration served as a beacon of hope for Richmond's leading ladies through the three-and-a-half months of life left in the Confederacy before its demise at the hands of the Union army in April, 1865.

On January 1, 1865, Reverend Charles Minnegerode preached a poignant and inspirational sermon to the congregation at St. Paul's Church that encapsulates the mindset of Richmonders that had prevailed throughout the 1864 Christmas celebration: 
Reverses have followed us in many parts of our country, and the sky opens with dark and threatening clouds, which have cast their shadow over every brow. What we need is a stout heart and a firm, settled mind: and oh! May we AS A NATION remember, "he that believeth shall not make haste..." I do pray and hope that God will have mercy upon us, and give us better minds and stout hearts and unfailing faith, that shall...win the prize. But if we fall, let us fall with our faces upward, our hearts turned to God, our hands in the work, our wounds in the breast, with blessing — not curses - upon our lips; and all is not lost! We have retained our honor; we have done our duty to the last. ${ }^{618}$

Even if only in the minds of the female elite, the "debt of honor" due to the war-ravaged

Confederate capital from her leading ladies, by virtue of both their social and economic standing, had been fulfilled.

618 Harold B. Gill, Jr., “Christmas Trees, the Confederacy and Colonial Williamsburg,” Colonial Williamsburg (Christmas, 2005), 73-74. 


\section{Conclusion-- “Pleading for Greater Light": \\ Women and the Written Reconstruction of Richmond in the Postwar Era}

On Sunday morning, April 2, 1865, the usual crowd of Richmond's leading ladies and gentlemen gathered at St. Paul's Church, their heads bowed in solemn prayer together with their less affluent sisters and brothers of the capital. The traditional Sunday service was suddenly interrupted by the arrival of a courier who delivered the fateful telegram to President Davis conveying the shocking news of the fall of Petersburg. Quietly putting on his coat, the President abruptly hurried from the church, the wide eyes of the congregation intensely focused upon him. The news from Petersburg quickly spread throughout the city, and during the next two days, the streets echoed with the clamor of thousands of anxious soldiers, politicians, and other men, women, and children of all classes who quickly began to prepare for the worst. Chaos soon erupted in the city streets. According to Judith McGuire,

Many ladies were now upon the streets. The lower part of the city was burning...As I went from Franklin to Broad Street...the pavements were covered with broken glass; women, both white and coloured, were walking in multitudes from the Commissary offices and burning stores with bags of flour, meal coffee, sugar, rolls of cotton cloth, etc; colored men were rolling wheelbarrows filled in the same way... as I proceeded, shouts and screams became louder. ${ }^{619}$

Within hours, long columns of panicked Richmonders and capital officials hurriedly

made their way across the James River, burning the city's bridges as they fled, while desperately hoping to escape from the blue mass of Union troops slowly making its way toward the doomed Confederate capital. As they turned to catch one final glimpse of their beloved city and national capital, the refugees struggled to make out the imposing outline of the capitol building, the elegant spires of the city's churches, and the stately homes of some of Richmond's most prominent societal leaders amidst the smoke and flames of the evacuation fire that now engulfed

619 McGuire, 345. 
over twenty blocks of the old city. Initially intended to destroy only the extra munitions and supplies inside the city's warehouse district, the fire quickly spread to other buildings and ravaged the heart of Richmond's downtown.

Several individuals refused to abandon their homes and instead took their chances by remaining in soon-to-be Federally occupied Richmond. Judith McGuire was one of them. Watching the city disappear before her eyes, McGuire grew numb at the sight of the city engulfed in flames. On April $3^{\text {rd }}$, McGuire wrote,

the fire was progressing rapidly and the crashing sound of falling timbers was distinctly heard. Dr. Read's church was blazing. Yankees, citizens, and negroes were attempting to arrest the flames. The War Department was falling in; burning papers were being wafted about the streets. The Commissary Department, without desks and papers, was consumed already. Warwick \& Barksdale's mill was sending its flames to the sky. Cary and Main Streets seemed doomed throughout; Bank Street was beginning to burn, and now it had reached Franklin. At any other moment it would have distracted me, but I had ceased to feel anything. ${ }^{620}$

For Phoebe Pember, who remained in Richmond for several days to continue caring for the wounded, and for Constance Cary, the city appeared to have completely changed. "People who had boxes of Confederate money and were wealthy the day previously looked around in vain for wherewithal to buy a loaf of bread," Pember noted. "Strange exchanges were made on the street of tea and coffee, flour and bacon. Those who were fortunate in having a stock of household necessaries were generous in the extreme to their less wealthy neighbors, but the destitution was horrible." ${ }^{\prime 621}$ Meanwhile, Constance Cary reflected on the obliteration of entire sections of the capital city:

I was wakened suddenly by four terrific explosions, one after the other, making the windows of my garret shake. It was the blowing up....by order of the Secretary of the Navy, of our gunboats on the James, the signal for an all-day carnival of thundering noise and flames...I set out for the Capitol Square.

620 McGuire, 348-9.

621 Pember, 82. 
Looking down from the upper end of the square, we saw a huge wall of fire blocking out the horizon. In a few hours no trace was left of Main, Cary and Canal Streets, from $8^{\text {th }}$ to $18^{\text {th }}$ Streets, except tottering walls and smouldering ruins. $^{622}$

For Richmond's leading ladies, the dramatic blaze symbolized not only the destruction of their homes and the Confederate seat of government, but also the end of a way of life for which they had fought through four long years of sacrifice, forceful ritual, and socio-political negotiation. In the wake of the evacuation, Richmonders such as Sallie Putnam watched in disgust as "unworthy" members of society's lower sects gleefully snatched up the city's leftover provisions, stripping bare the stores of food and supplies that had lent the capital elite their former distinction:

Those who had enriched themselves by plundering the stores were busy in conveying off their goods. Laughing and jesting negroes tugged along with every conceivable description of merchandise, and many an astute shopkeeper from questionable quarters of Richmond thus added greatly to his former stock. ${ }^{623}$

Suddenly, even the proud descendants of the original founders of the city found themselves completely awash in the vast sea of refugees, but this time, they were utterly powerless in stemming that tide. For Sallie Putnam, "the humiliation...[could] not be estimated." Much to her horror, "intermingled in a strange, incongruous and hitherto unacquainted throng might be seen some of the most refined and delicate, nurtured of the women of Virginia...with the coarse, rude and vulgar of questionable parts of the city, and frequently with negroes who had left their former homes and thus took their first step to freedom." ${ }^{\text {,624 }}$ According to Judith McGuire, the ladies "fel[t] as if we were groping in the dark. No one kn[ows] what to do." Uprooted from their ancestral homes and from both the social and political protection afforded

622 Harrison, 211.

623 Putnam, 369.

624 Putnam, 373.

625 McGuire, 349. 
them by their gender and class status, Richmond's native ladies joined their peers in the search for mere survival during the final days of the Confederacy.

That search would extend far beyond April 9, 1865, however, as many of Richmond's former female figureheads quickly realized that physical survival meant very little without the reconstruction of the society upon which their identity as leading southern ladies rested. Despite the diaspora of this once insular group of women throughout the newly reunited country, as well as abroad, to places such as England, France, Cuba, South America, and the Caribbean, the desire of the female elite to reconstruct, in memory if not in reality, the cherished society of the past united a majority of them in common cause. If the ladies were ultimately unable to inspire their peers to help rebuild their "kingdom" of prior days, at least they might live in the comfort of knowing that that world had been preserved forever by their own words. Shortly after the war, these women, both angered and insulted by the Federal government's attempts at national Reconstruction, found refuge, comfort, and redemption in recording and publishing their memoirs of life in wartime Richmond, whether their intended audience was merely themselves and their family, or the larger public.

And so, according to Sallie Putnam, "with memories crowding up like trooping phantoms, some beautiful and pleasant, some taunting and derisive" the fingers of the leading ladies "toy[ed] listlessly with a Key." For Richmond's former leading ladies during the postwar era, that key to the past was "somewhat tarnished, but the red stains are partially worn off by recent use. What must be done with it?" Putnam asked. Regardless of the stains and tarnishing from time that might prevent them from ever fully recovering the past, the ladies were of one spirit regarding the need to try: "We feel that there is something in the locked chamber that will interest us - something that the world will be wiser and better for knowing," Putnam stated. And 
so, they "turn[ed] the key, to reveal the secrets held by the Confederate Capital during four years of terrible civil war."626

Many of these women simply refused to believe that there was not "life in the old land yet" that they might help to restore through their writings. Sallie Putnam fiercely believed that "there is a great destiny in reserve" for the former Confederate capital. Indeed, she wrote, earthly malice would be powerless to prevent it. Her climate invites it, her geographical position court it, the intelligence, enterprise, and industry of her inhabitants will compel it; by her side the flowing waters of the classic stream upon which she proudly looks, send up a never ceasing cry to expend our might in works for her prosperity. ${ }^{627}$

Through the publishing of diaries and wartime memoirs, Richmond's former ladies did indeed extend that might. Those memoirs, combined with other contemporary sources, are both what have shaped our understandings — and, admittedly, misunderstandings — of Confederate Richmond to date. Fittingly, in response to Putnam's hope that "the rising generation...forget not her ancient prestige," that "they plead for still greater light, they call for an increase of educational resources," those memoirs are also what have given this dissertation life. ${ }^{628}$

Admittedly, as conscious historians of a by-gone era, many of these women, such as Judith McGuire, Mary Chesnut, Constance Cary, Sallie Putnam, and Virginia Clay each had their own agendas in publishing their wartime diaries or memoirs. While some of the ladies sought merely to set the record straight for posterity on life in wartime Richmond, others adamantly strove to affirm a particular political, racial, gendered, or class-driven agenda that glorified the actions of Richmond's ladies and their wartime community, while simultaneously condemning the Union for its decimation of southern society. Regardless of the ladies' conscious agendas, their writings often reflected the era and area in which they lived during the postwar period, with 
nostalgia and memory constantly contesting truth and reality throughout the publishing process. As a result, they must be appropriately filtered through the temporal and spatial contexts in which they were produced. In the past fifty years, historians such as David Blight, Caroline Janney, Jane Turner Censer, Fitzhugh Brundage, William Blair, Edward Ayers, and others have produced an abundance of rich scholarship on the making of historical memory in the postwar years, and particularly on the contributions of southern women and their writings to the rise of the Lost Cause mentality of the late nineteenth century. ${ }^{629}$ These studies have been invaluable to our understandings of southern women, memorial societies, and women's writings as active participants in the shaping of Confederate memory.

However, what has also emerged from those writings is a colorful, complex, and sometimes confounding picture of a society and a people forced to reckon with myriad challenges to identity and authority in the face of a war that proved not only "civil" but also "civic" in nature. Doubtless, other, major urban hubs in the Confederacy such as Atlanta, New Orleans, and Charleston possessed their own, unique societies with their own respective social tensions and wartime challenges to which they responded in their own way. However, as the Confederate capital, Richmond stood for four years as the heart and heartbeat of the Confederate nation and thus a conspicuous model for southern society. Although these ladies' writings may not always represent an exact depiction of reality in wartime Richmond, when filtered through the era in which they were written and when analyzed through the cultural context of ritual, they do produce a fascinating lens into the evolving worldviews, social perceptions, and selfconsciousness of the leading ladies of the Confederate capital.

${ }^{62}$ Scott, From Pedestal to Politics; Janney, Burying the Dead But Not the Past; Censer, The Reconstruction of White Southern Womanhood; Blight, Race and Reunion; Blair, Cities of the Dead; Ayers, The Promise of the New South; W. Fitzhugh Brundage, The Southern Past: A Clash of Race and Memory (Cambridge: Harvard University Press, 2008). 
Those writings reveal that, like anyone else, these elite women were deeply complex individuals whose lives often were governed by profoundly conflicting notions of self and society and by multiple tiers of consciousness. As slaveholding women who were active and prominent members of a slaveholding society, their writings and behaviors also illustrate the pervading influence of slavery's social dynamics upon these women's interpersonal relationships as a whole. The ever-contested, contractual power dynamics between master and slave infiltrated nearly all relationships within southern society — a society so deeply rooted in and fundamentally shaped by the political, economic, social, and cultural forces of the "peculiar institution" that it would take decades to even begin to disentangle itself from slavery in the postwar years.

As both the actions and the writings of Richmond's leading ladies illustrate, the core of nearly all of these women's wartime relationships with their social inferiors - both black and white - in the Confederate capital also pivoted around both a grand and forceful display of classbased power from above, in order to compel the deference of the lower classes, and a subtle, but significant, negotiation between the elite and their subordinates for various aspects of social power and individual interest. Thus, it appears that elite white women's wartime relationships with refugees, the poor, and both free and enslaved African-Americans were undeniably shaped by their pre-war understandings of and participation in what had been a uniquely contractual, but always in-flux system of pre-war power relations.

Antebellum society had demanded that both masters and mistresses work in tandem to carefully safeguard the power that they held over their chattel. During the Civil War, elite women and the once "orderly" society from which they derived their unique class prowess faced myriad social and political challenges, not only from African-Americans, but also from poor 
whites and refugees. In response, both their forceful projections of power and their subtle negotiations with their social "inferiors" for class deference were directly shaped by their evolving perceptions of those contractual, antebellum relationships. Throughout their interactions with the poor, with refugees, and with the black community, elite white women believed that they were merely fulfilling their unique social roles and responsibilities as the female complements to the paternalist leaders of wartime Richmond, and as the wartime guardians of an endangered social order whose members' privilege was continuously contested. $^{630}$

Lavish social events and cultural rituals, (termed "social jumbalaya" by nineteenthcentury journalist, T.C. DeLeon), were integral to maintaining this precarious communal order and to maintaining morale among the Confederacy's leaders. ${ }^{631}$ They reveal the intriguing (and often overlooked or mis-read) ways in which the capital elite, and particularly elite women, attempted both to reaffirm their place at the top of the social "pecking order" before incoming strangers, refugees, African-Americans (both free and enslaved), and the poor, and to impose their own notions of propriety and morality upon Richmond's wartime society.

Social events and cultural rituals such as holiday celebrations, theater-going, home visits, promenades, "starvation parties," and public charity events provided critical opportunities for women of the "capital elite" to engage with members of the lower classes and with refugees, either through direct interactions or amplified awareness of "the other." Numerous nineteenthcentury slave narratives and African-American literature also clearly illuminate the ways in which white women interacted with both free and enslaved blacks through public events and

630 Genovese, Roll, Jordan, Roll.
631 Thomas Cooper DeLeon, Belles, Brains, and Beaux of the 60's (New York: G.W. Dillingham Company, 1909). 
demonstrations. ${ }^{632}$ All of these engagements served as forums in which elite women not only strove to negotiate the power dynamics of their ever-fluid society through a show of forcefulness from "above," but also sought to learn how to adjust their own behavior appropriately. Such retailoring of their own behavior to adequately meet the needs and wants of their inferiors was essential in order for the ladies to gain the deference of those from "below" - that is, the "masses" of society whose potentially considerable influence in either upholding or destroying the "proper" social order upon which the ladies' public prowess rested was far too great to ever ignore. ${ }^{63}$

In the past, scholarship on southern women during the Civil War has focused largely on the experiences of various Confederate women throughout the war, and on the debate over whether southern women were instrumental to fostering Confederate nationalism or whether their efforts ultimately undermined the war effort. Such studies have provided valuable information about the war's impact on female civilians in the South and have generated necessary discussion about female agency within the Confederate war effort. ${ }^{634}$ However, only a handful of these studies have applied a more culturally focused methodology to capture the

\footnotetext{
632 Much primary source material is available on this topic. For example, see Frederick Douglass, My Bondage and My Freedom (Miller, Orton, \& Mulligan, 1855); reprint, ed. John David Smith (New York: Penguin Group, Inc., 2003); Louis Hughes, Thirty Years a Slave: From Bondage to Freedom, The Institution of Slavery as Seen on the Plantation in the Home of the Planter (Milwaukee: South Side Publishing Co., 1897); reprint, (Montgomery, AL: NewSouth, Inc., 2002).

633 T.J. Jackson Lears, "The Concept of Cultural Hegemony: Problems and Possibilities," The American Historical Review 90, no. 3 [June, 1985]: 567-593.

${ }^{634}$ Laura F. Edwards. Scarlett Doesn't Live Here Anymore: Southern Women in the Civil War Era. (Chicago: University of Illinois Press, 2004); Jacqueline Glass Campbell. When Sherman Marched North From the Sea: Resistance on the Confederate Homefront (Chapel Hill: The University of North Carolina Press, 2007); LeeAnn Whites and Alecia Long. Occupied Women: Gender, Military Occupation and the American Civil War (Baton Rouge: Louisiana State University, 2009); Nina Silber, Gender and the Sectional Conflict (Chapel Hill: The University of North Carolina Press, 2008); Drew Gilpin Faust. Mothers of Invention: Women of the Slaveholding South in the American Civil War (Chapel Hill, NC: The University of North Carolina Press, 1996); George C. Rable, Civil Wars: Women and the Crisis of Southern Nationalism (Chicago: University of Illinois Press, 1989); Drew Gilpin Faust, "Altars of Sacrifice: Confederate Women and the Narratives of War," The Journal of American History 76, no. 4 [March, 1990], 1200-1228; Catherine Clinton and Nina Silber, eds., Divided Houses: Gender and the American Civil War (New York: Oxford University Press, 1992); Catherine Clinton, ed. Half-Sisters of History: Southern Women and the American Past (Durham, NC: Duke University Press, 1994); Catherine Clinton, ed. Southern Families at War: Loyalty and Conflict in the Civil War South (Cambridge: Oxford University Press, 2000); Anne Firor Scott, The Southern Lady: From Pedestal to Politics, 1830-1930 (Charlottesville: University of Virginia Press, 1970; repr, 1995).
} 
deeper meanings and symbolism of southern women's actions and the larger worldviews that infused southern women's social behavior. ${ }^{635}$ As a result, many historians have dismissed elite women's elaborate dinners, balls, promenades and parlor parties as evidence of selfish and inappropriate war-time indulgences that senselessly isolated them from the refugees and the impoverished classes.

These same historians likewise have scorned elite women's episodic demonstrations of charity and benevolence toward those "outsider" groups as patronizing and ineffective. One camp of these scholars has dismissed the actions of elite women entirely and instead, has championed the work of middling and even lower class southern women as the true "rocks and patriots" of the Confederate home front, citing their unrelenting dedication toward soldier relief efforts, heroic defiance against the enemy, and a complete disregard for personal desires. ${ }^{636}$ Other scholars have noted such communal dedication in the earlier part of the war, but have scorned southern women of all classes for ultimately "giving up" the war effort in its late years. ${ }^{637}$ Indeed, several prominent historians have even ventured so far as to suggest that the "selfishness" and isolationism of the female Confederate elite from the rest of society directly conflicted with the selfless and charitable acts of middling southern women to a point that such behavior actively unraveled society, undermined the Confederate war effort and contributed, in no small measure, to the ultimate demise of the Confederate nation. ${ }^{638}$

\footnotetext{
635 Stephanie McCurry. Confederate Reckoning: Power and Politics in the Civil War South (Cambridge: Harvard University Press, 2010); Thavolia Glymph, Out of the House of Bondage: The Transformation of the Plantation Household (New York: Cambridge University Press, 2008); Nina Silber, Gender and the Sectional Conflict (Chapel Hill: The University of North Carolina Press, 2008).

636 Laura F. Edwards, Scarlett Doesn't Live Here Anymore: Southern Women in the Civil War Era (Chicago: University of Illinois Press, 2004); Jacqueline Glass Campbell, When Sherman Marched North From the Sea: Resistance on the Confederate Homefront (Chapel Hill: The University of North Carolina Press, 2007); LeeAnn Whites and Alecia P. Long, | Occupied Women: Gender, Military Occupation and the American Civil War (Baton Rouge: Louisiana State University, 2009). 637 Nina Silber, Gender and the Sectional Conflict (Chapel Hill: The University of North Carolina Press, 2008).

638 Drew Gilpin Faust, Mothers of Invention: Women of the Slaveholding South in the American Civil War (Chapel Hill, NC: The University of North Carolina Press, 1996); George C. Rable, Civil Wars: Women and the Crisis of Southern Nationalism (Chicago: University of Illinois Press, 1989); Drew Gilpin Faust, "Altars of Sacrifice: Confederate Women and the Narratives of War," The Journal of American History76, no. 4 [March, 1990], 1200-1228.
} 
Even more recently, historian Stephanie McCurry has proffered that, aside from episodic demonstrations of charity and benevolence toward their fellow citizens and the AfricanAmerican population, both elite and non-elite southern white women's chief contribution to the war effort lay in their ability to transform themselves into powerful political actors through formal petitions, demonstrations, council and even physical aid to the Confederate government and to their local communities. ${ }^{639}$ However, both McCurry and others have focused so much upon the purely political and formalized actions of women that they have overlooked the informal social channels through which the capital elite engaged the subordinate classes and helped to maintain social order. By analyzing those informal relations within urban Richmond, we are able to attain a deeper understanding about elite women's perceptions of social order and their social and political responsibilities, as well as the ways in which they relied on the power of informal social relations, politics, and cultural events to try to help stabilize their society during wartime. Such an approach helps us to resist the moralizing urge to immediately indict elite women for their often lavish social engagements during the war, instead identifies in those events a deeper system of ritual and power dynamics at play, and allows us to appreciate such dynamics as a critical component of Richmond's complex social ordering.

In turn, this approach also helps us understand how and why these leading ladies ended up (however subconsciously) alienating themselves, in many instances, from the very people whose loyalty and respect they worked so hard to attain. Additionally, it illuminates a possible explanation for how and why class-based, and in some instances gendered disaffection for the leading ladies grew and thrived throughout the war among many of the ladies' most vocal critics. Finally, such an approach reveals the evolution in the ladies' perceptions and execution of social

${ }^{639}$ Stephanie McCurry, Confederate Reckoning: Power and Politics in the Civil War South (Cambridge: Harvard University Press, 2010). 
responsibility, moral guardianship, and privilege toward more private and inward-facing, yet more expressively justified social rituals, while simultaneously revealing a perseverance and tenacity of purpose behind those rituals, over the course of four long years of war.

Throughout this dissertation, I have sought to uncover what historian Steven M. Stowe calls a "shared mentality that lies between observable behavior... and formal systems of thought" to show how elites both made sense of their world and sought to project that unique understanding of people and relationships onto society itself. ${ }^{640}$ Like Stowe, I have contended that the establishment of both social legitimacy and dominance was critical to defining and maintaining elite social status and authority in the Confederate capital as well. ${ }^{641}$ As Stowe has noted, "the clear hierarchical scheme of value and belief in family and society was celebrated" with social codes that applied to a ranked public order. One's self-esteem and personal sense of honor was inextricably linked to one's ability to achieve social stability. By leading a moral, "good" life, one could achieve both, but only if one was perpetually aware of his or her appearance and agreed to adopt a lifestyle of "showy displays of their beliefs" that helped to legitimize elite authority and promote broader social order. According to Stowe, southerners of the planter class were always aware of the need to craft carefully their public projections of themselves. ${ }^{642}$

Similar to Stowe's work, this dissertation has argued that social rituals in the planter south evolved out of a conscious need to achieve a personal balance between indulgence and self-control before the critical public eye. However, when trying desperately both to reaffirm, through symbolic behavioral "language," their social status and ultimately re-order Richmond

640 Steven M. Stowe. Intimacy and Power in the Old South: Ritual in the Lives of the Planters (Baltimore: Johns Hopkins University Press, 1987), xiii.

641 Stowe, $x v$.

642 Stowe, xviii. 
society according to their understanding of hierarchy, Richmond ladies often were blinded by what Stowe aptly calls their own "aptitudes for thinking and feeling." Thus, the ladies frequently earned the scorn of both social peers and inferiors who did not fully understand the social "language" through which the ladies were trying to communicate. Although the ladies were at times successful in communicating empathetic sentiments to the lower classes, their tendency to "live in two dimensions--the present and one's breeding"-frequently prevented them from ever fully engaging with their inferiors and successfully winning over some of their most vocal critics. Therefore, Richmond ladies were constantly forced to negotiate with their peers and their social inferiors for the power and ability to mediate the world around them according to their own ideas of moral and social order. ${ }^{643}$

Nevertheless, elite southerners held fast to the use of cultural rituals and social performances as a way to display the mastery of noble qualities such as honor, morality, and respectability that the elite so desperately needed to possess. ${ }^{644}$ Through such demonstrations, the elite struggled to maintain a cultural authority that would successfully persuade the rest of society that "their reality" of social order was "THE reality." ${ }^{645}$ The fight for cultural authority proved as strong among women as it was for their men, for, although women were never considered the social equals of men, they shared men's elite standing and thus shared the "same stake in the survival of elite authority."

Additionally, in the vein of Stowe, I have contended that the culture of the Confederate capital was not static, but that it was constantly evolving through the challenges of war. The social and political turbulence in war-time Richmond placed increasing emphasis on the need for

643 Stowe, $1-3$.

644 Stowe, 162.

645 Stowe, 230.

646 Stowe, 251. 
Richmond's ladies to live their lives "as if they were always in view." Observed, judged, criticized, and constantly evaluated by their peers and by the lower classes, these women knew that "even in private, their words echoed in the outside world." I believe that these women were aware that "indeed, there was really no 'outside' if one took one's elite standing seriously, and if one did not," they took a risk that "threatened everyone implicated in mastery." ${ }^{647}$ Thus, elite women knew that, in order to maintain their privileged status and a moral social order within the Confederate capital, their social ambitions had to move beyond expression and into "exhibition." In the words of Stowe, "culture was plumage for display, consciousness had to be made manifest," and the ladies always had to make sure that they "appeared to an advantage" to those watching from all rungs of society. When such exhibitions succeeded, elites felt what Stowe has described as a "deep unity of image and action, personal belief and social influence." However, if the ladies' social performances failed, they might make the disastrous mistake of "flaunt[ing] falsehoods, mis[taking] ambition and desire, and running the risk of exposure by one's lesser." For the ladies of Richmond, "keeping up appearances, then, was not trivial because it was always attractive (and often necessary) to believe" that ladies' appearances as the legitimate social and moral arbiters of the city were real, and that the hierarchically and morally ordered society of their imaginations was "as real as anything else that the master class could make."648

By analyzing, through the lens of ritual, elite women's social engagements, selfpresentation, occupation of various public and private spaces, and interactions with their peers and the poor-both white and black - this dissertation reveals how individuals, in general, have relied on a variety of unofficial and often informal social interactions as rituals through which they have sought both to reaffirm their own contested identities and to affect broader social 
change upon society as a whole. However, this valuable portal into these women's minds also brings us ever closer to understanding the complexities of gender roles in the Civil War South, the evolving mental frameworks that governed the lives and actions of this influential group of actors, the changing power dynamics that shaped social relationships and the functioning of the Confederate capital, and the inner world of the capital elite that, truly, was as real to them as anything that Richmond's leading ladies could ever make. 


\section{BIBLIOGRAPHY}

\section{Primary Sources}

\section{Special Collections and Manuscripts}

Albert and Shirley Small Special Collections Library, University of Virginia Library Diary of Clara Shafer

Papers of Henry Heth

Papers of Mary Kelly Watson Smith

"Documenting the American South: Primary Resources for the Study of Southern

History, Literature, and Culture." University of North Carolina at Chapel Hill, 2004. $<$ docsouth.unc.edu>

Diary of Anita Dwyer Withers, May 4, 1860-June 18, 1865

Eleanor S. Brockenbrough Library, Museum of The Confederacy, Richmond, Virginia Civilian and Home Front Collection (much of this collection is uncatalogued)

Kate Rowland papers

Kate Mason Rowland diary

Randolph family papers

Soup Association of Richmond Minute Book

Davis Family Collection

Varina Davis correspondence

Hospital Collection

Sally Louisa Tompkins and Hospital Collection

Medical Personnel Box

Sally Louisa Tompkins and Robertson Hospital Collection

Southern Women's Collection

Abby Gwathmey file

Adelaide Clopton file

Clara Minor Lynn files

Ellen Wise Mayo file

Isabel Maury file

Janet Weaver Randolph file

Kate Pleasants Minor file

Ladies Defence Assocation file

Ladies Gunboat Association file

Nanny Kent letters

Lucy Mayo file

Margaret Louborough file

Maria Clopton file

Mrs. A.J. Ellis file 
Mrs. Martha Mary Reid file

Mrs. Mary Fitch letters

Mrs W.A. Simmons file

Stella Blanton file

"To my Children: The Days of Strife in Civil War" (anon.) file

Vertical files

Ruth Ann Coski, Christmas program notes.

Ruth Ann. "Christmas Timeline.” November, 1988. Vertical

files, Christmas programs file.

William Greer. Letter, December 25, 1862.

Fredericksburg and Spotsylvania National Military Park Archives (Courtesy of John Hennessey, Chief of Interpretation), Fredericksburg, VA

Bernar, Fanny. "The Shelling of Fredericksburg: Recollections of One Who Was a Little Girl at That Time. The Terrible Destruction: Scenes of War Vividly Described, Etc." Fredericksburg Daily Star, December 6, 1909. [Transcription]

Catherine Couse letters

Diary of E.C. French, September 1, 1864-May 26, 1866

Diary of Matilda Hamilton (1817-1875) of Forest Hill [Transcription]

Elizabeth Gordon Rennolds recollections [Transcription from originals, Virginia Historical Society, Richmond, VA]

Ella McCarty letters to Hugh Martin

George Washington Fields memoir

Heinichen memoir

Knox family letters

"Letter from a Lady near Spotsylvania" (Sallie Todd), May 15, 1864.

Montgomery, Alabama Advertiser. June 8, 1864. [Transcription]

Maria Dobyns letter, June 17, 1864

Mary Gray Caldwell diary (scan)

Journal of Lizzie Maxwell Alsop, Fredericksburg, VA

Lacy, Betty Churchill. "Memories of a Long Life.” April, 1903

"Personal Recollections of the Battle of Chancellorsville (By a Chancellor of

Chancellorsville- a child of 14 years) -Now Mrs. Sue Chancellor.

Compiled by Mrs. Emily W. Fleming, Fredericksburg, Virginia.

Scott, Bradford Ripley Alden. "Memoirs of the Civil War"

The Journal of Jane Howison Beale, Fredericksburg, Virginia, 1850-1862

Wells, Mamie. "Reminiscences of the Late War," Chapter II. Fredericksburg Star, July 14, 1888. [Transcription].

Library of Congress Manuscripts Collection

Burton Harrison papers

The Papers of Burton Harrison and Family (Constance Cary Harrison

correspondence) 
Jefferson Davis papers

Louis T. Wigfall papers

Library of Virginia Manuscripts Collection

Mary B. Goodwin diary

Memorial Foundation for Children Account Book, Dec. 1858-Dec. 1867

Robinson-Morgan Family papers

David M. Rubenstein Rare Book \& Manuscript Collection, Duke University Library Munford Family papers

Munford Ellis papers

Clement C. Clay papers

Southern Historical Collection, Lois Round Wilson Library, University of North

Carolina at Chapel Hill

Burwell family papers

Christopher Gustavus Memminger papers

DeRosset family papers

Drury Lacy papers

J.G. Ramsay papers

Mordecai Family papers

Phoebe Yates Pember letters

Rennie Family papers

Virginia Clay diary

Virginia Historical Society, Manuscript Collection

"A Perfect Woman," by Janet H. Weaver

Account book of the Memorial Foundation for Children

Alice Jane Mosby Gardner letter, December 27, 1864

Anna Trenholm diary

Armistead, Blanton, and Wallace family papers

Aylett Family papers

Catherine Cochran memoir

Claiborne/McGuire papers

Coons Family papers

Duke, Jane Taylor. "Richmond Home for Boys, 1846-1955." [N.d.]

Early Family Papers: Emma Bryan, "Reminiscences"

Emma Moredecai diary

Fanny Braxton letters

Female Humane Society, Historical Sketch of Richmond's Oldest Charity

Gertrude R.B. Richards. The Ladies Speak. Compiled 1928-1945.

Grace and Holy Trinity Church Parish Records, Vestry Minutes and History

Gwathmey Family papers

Hankins Family papers

Harrison Family papers 
Hawes Family papers

Laws in Relation to the Overseers of the Poor

Lee Family papers

R.E. Lee correspondence

M.C. Lee correspondence

Maria Mason Tabb Hubard diary

Maria Peek Smith Marrow letters

Margaret Brown Wight diary

McCarty Family papers

McGuire Family papers

Memorial Foundation for Girls History

Monumental Episcopal Church Vestry Book

Morris Family letters, 1861-1865

Moses Hoge letters

Papers, 1844-1968, of the Cary family of Hampton and Richmond, VA

Papers, 1831-1882, of the Seddon family of Richmond and Goochland County, VA

Papers, 1859-1899, of the Waring family of Powhatan County, VA

Pegram-Johnson-McIntosh family papers

Randolph Family papers

Rives Family letters

Samuella Hart Curd diary

Stanard Family papers

St. Paul's Church Record of the Vestry, No. 3

St. Paul's Church file

Susan Gatewood Crutchfield Maury diary

Wight Family papers

Wise Family papers

Court and City Council Records

Richmond City Council Records 14-15, 1857-1866

Richmond Husting's Court Minutes 27 (1860-1861), 28 (1862-1863)

Richmond Mayor's Court Records

Journals, Magazines, and Periodicals

Virginia Magazine of History and Biography. Vol. 116, no. 4. Richmond, VA: Virginia Historical Society, 2008.

Newspapers and Periodicals

Children's Friend

Christian Observer

Richmond Daily Dispatch

Richmond Daily Sentinel

Richmond Daily Whig

Richmond Enquirer

Richmond Examiner 
Southern Churchman

Southern Literary Messenger

Southern Opinion

Southern Punch

Published Primary Sources

Alfriend, Edward M. "Social Life in Richmond During the War," in ed. R.A. Brock, Southern Historical Society Papers. Vol. 19. Pp. 380-386. Richmond, VA: Southern Historical Society, 1891.

Avary, Myrta Lockett. A Virginia Girl in the Civil War, 1861-1865. New York: D. Appleton and Company, 1903.

Beers, Fannie. A Record of Personal Experience and Adventure During Four Years of War. Philadelphia: JB Lippincott Company, 1891.

Bibb, Henry. Narrative of the Life and Adventures of Henry Bibb, An American Slave, Written by Himself. New York, 1849. In eds. William L. Andrews and Henry Louis Gates, Jr., Slave Narratives. New York: Literary Classics of the United States, Inc., 2000. Reprint, 2001.

Blackiston, Henry C., ed. Civil War Letters of a Virginia Family. Princeton: Princeton University Press, 1989.

Boggs, Marion Alexander, ed. The Alexander Letters, 1787-1900. Savannah: Printed privately for George J. Baldwin, 1910.

Braxton, John R. "Christmas on the Rappahannock." In Civil War Times Illustrated, December, 1973.

Brown, Henry "Box." Narrative of the Life of Henry Box Brown, Written by Himself. Edited by John Ernest. Chapel Hill: The University of North Carolina Press, 2008.

Brown, William Wells. Clotel; or, The President's Daughter. Great Britain: Partridge \& Oakey, 1853. Reprint, ed. M. Giulia Fabi. New York: Penguin Group, Inc., 2004.

Brown, William Wells. My Southern Home: or, The South and Its People. Boston, 1880. Reprint, New York: Mentor Books, 1993. Reprint, ed. William L. Andrews. Columbia, MO: University of Missouri Press, 2003.

Brown, William Wells. The Escape; or, A Leap for Freedom. Ed. John Ernest. Knoxville, TN: The University of Tennessee Press, 2001.

Brown, William Wells. "Under the Stars and Stripes," in eds. Philip S. Foner and Robert 
James Branham, Lift Every Voice: African American Oratory, 1787-1900. Tuscaloosa, AL: The University of Alabama Press, 1998.

Burton Annie L. Memories of Childhood's Slavery Days. Boston: Ross Publishing Company, 1909. In ed. Henry Louis Gates, Jr., Six Women's Slave Narratives, The Schomburg Library of Nineteenth-Century Black Women Writers. New York: Oxford University Press, 1988.

Clay-Clopton, Virginia. A Belle of the Fifties: Memoirs of Mrs. Clay of Alabama. New York: Doubleday, Page \& Company, 1905. Reprint, Tuscaloosa, AL: The University of Alabama Press, 1999.

Chesnut, Mary Boykin. Mary Chesnut's Civil War. Ed. C. Vann Woodward. New Haven, CT: Yale University Press, 1981.

Chesnut, Mary Boykin Miller. A Diary From Dixie, as Written by Mary Boykin Chesnut, Wife of James Chesnut, Jr., United States Senator from South Carolina, 1859-1861, and Afterward and aide to Jefferson Davis and a Brigadier-General in the Confederate Army. New York: D. Appleton and Company, 1905.

Confederate Veteran, 23, no. 6 (June, 1915).

Crist, Lynda L. and Mary S. Dix, eds. Jefferson Davis Papers. Vol. 7: 1861. Baton Rouge: Louisiana State University Press, 1992.

Crist, Lynda L., Mary S. Dix, and Kenneth H. Williams, eds.. Jefferson Davis Papers. Vol. 8: 1862. Baton Rouge: Louisiana State University Press, 1995.

Crist, Lynda, Mary S. Dix, and Kenneth Williams, eds. Jefferson Davis Papers. Vol. 9: January-September, 1863. Baton Rouge: Louisiana State University Press, 1997.

Crist, Lynda, Kenneth H. Williams, and Peggy L. Dillard, eds. Jefferson Davis Papers. Vol. 10: October 1863-August 1864. Baton Rouge: Louisiana State University Press, 1999.

Crist, Lynda. Barbara J. Rozek, and Kenneth H. Williams, eds. Jefferson Davis Papers. Vol. 11: September 1864-May 1865. Baton Rouge: Louisiana State University Press, 2003.

Dame, William Meade. "From the Rapidan to Richmond." In Georgia Magazine, December 1961-January 1962.

Davis, Varina. "Christmas in the Confederate White House." New York Sunday World, December 13, 1896.

Davis, Varina. Jefferson Davis, Ex-President of the Confederate States of America; a 
memoir by his wife. New York: Belford Company, 1890.

Dawson, Sarah Morgan. A Confederate Girl's Diary. Reprint, The Civil War Diary of Sarah Morgan Dawson. Ed. Charles East, 1960. Reprint, Athens, GA: University of Georgia Press, 1991.

DeLeon, T.C. Belles, Brains, and Beaux of the 60's. New York: G.W. Dillingham Company, 1909.

DeLeon, T.C. Four Years in Rebel Capitals: An Inside View of Life in the Southern Confederacy from Birth to Death. Mobile, AL: The Gossip Printing Co., 1890.

Douglass, Frederick. My Bondage and My Freedom. Miller, Orton, \& Mulligan, 1855. Reprint, ed. John David Smith, New York: Penguin Group, Inc., 2003.

Douglass, Frederick. "What, to the Slave, is the Fourth of July?" In eds. Foner and Branham, Lift Every Voice: African American Oratory, 1787-1900. Tuscaloosa, AL: The University of Alabama Press, 1998.

Drumgoold, Kate. A Slave Girl's Story. Brooklyn, NY, 1897. In ed. Henry Louis Gates, Jr., Six Women's Slave Narratives, The Schomburg Library of Nineteenth-Century Black Women Writers. New York: Oxford University Press, 1988.

Edmondston, Catherine Ann Devereux. Journal of a Secesh Lady: The Diary of Catherine Ann Devereux Edmondston, 1860-1866. Eds. Beth Gilbert Crabtree and James W. Patton. Raleigh: North Carolina Division of Archives and History, 1979.

Evans, Augusta Jane. Macaria, or, Altars of Sacrifice. 1864. Reprint, Baton Rouge: Louisiana State University, 1992.

Fayard, Dr. Cecil A., Jr. "Jefferson Davis' Walk of Faith, Part 6: The Benevolence of Jefferson Davis." Southern Historical Papers, 43 (1920).

Gorgas, Josiah. The Journals of Josiah Gorgas, 1857-1878. Ed. Sarah Woolfolk Wiggins. Tuscaloosa, AL: University of Alabama Press, 1995.

Grimes, William. Life of William Grimes, The Runaway Slave . 1855. Reprint, eds. William L. Andrews and Regina E. Mason, New York: Oxford University Press, 2008.

Harrison, Constance Cary. "Richmond Scenes in '62." In Battles and Leaders of the Civil War: being for the most part contributions by Union and Confederate officers. Vol. 2, 439-448. New York: The Century Company, 1887-1888. Reprint, ed. Thomas Yoselof, New York: Thomas Yoselof, Inc., 1956.

Harrison, Mrs. Burton. Recollections Grave and Gay. New York: Charles Scribner's 
Sons, 1911.

Harper, Frances E.W. Iola Leroy, or, Shadows Uplifted. Philadelphia: Garrigues Brothers, 1893. Reprint, ed. Henry Louis Gates, Jr., Six Women's Slave Narratives, The Schomburg Library of Nineteenth-Century Black Women Writers. New York: Oxford University Press, 1988.

Hughes, Louis Thirty Years a Slave: From Bondage to Freedom, The Institution of Slavery as Seen on the Plantation in the Home of the Planter. Milwaukee: South Side Publishing Co., 1897. Reprint, Montgomery, AL: NewSouth, Inc., 2002.

Jacobs, Harriet, ed. Lydia Marie Child. Incidents in the Life of a Slave Girl. Boston, 1861; in eds. William L. Andrews and Henry Louis Gates, Jr., Slave Narratives. New York: Literary Classics of the United States, Inc., 2000. Reprint, 2001.

Jones, John B. A Rebel War Clerk's Diary. Ed. Earl Schenck Miers. New York: Sagamore Press, Inc., 1958.

Jones, Katharine, ed. Ladies of Richmond: Confederate Capital. The Bobbs-Merrill Company, Inc., compiled 1962.

Langston, John Mercer Langston. "There is No Full Enjoyment of Freedom For Anyone in This Country," in eds. Foner and Branham, Lift Every Voice: African American Oratory, 1787-1900. Tuscaloosa, AL: The University of Alabama Press, 1998.

Letter of Hannah Garlick Rawlings, August 9, 1865. In Andrew Buni, ed., "Reconstruction in Orange County, Virginia: A Letter from Hannah G. Rawlings to Sister Clarissa Lawrence Rawlings, August 9, 1865," VMBH, Vol. 75, no. 4 (October 1867), 459-465.

Logan, Kate Virginia Cox. My Confederate Girlhood: The Memoirs of Kate Virginia Cox Logan, edited by her daughter, Lily Logan, Morrill. Richmond: Garrett \& Massie, Inc., 1932. Library of Congress, Washington, D.C.

Louborough, Margaret Cabell Brown. The Recollections of Margaret Cabell Brown Louborough: A Southern Woman's Memories of Richmond, VA and Washington, D.C. in the Civil War Era. Ed. James H. Johnston. New York: Hamilton Books, The Rowman and Littlefield Publishing Group, 2010.

Magill, Mary Tucker. Women: Or Chronicles of the Late War. Baltimore: Turnbull Brothers, 1871.

Martell, Joanne, ed. American Christmases: Firsthand Accounts of Holiday Happenings From Early Days to Modern Times. Winston-Salem, NC: John T. Blair, 2005.

Maury, Betty Herndon. The Confederate Diary of Betty Herndon Maury, 
Daughter of Lieut. Commander M.F. Maury, “The Pathfinder of the Sea." Ed. Alice Maury Parmelee. Washington: Privately printed, 1938.

McDonald, Mrs. Cornelia Peake. A Diary with Reminiscences of the War and Refugee Life in the Shenandoah Valley, 1860-1865. Louisville: 1875. Annotated and supplemented by Hunter McDonald. Nashville: Cullom \& Ghertner Co., 1934.

McGuire, Judith W. Diary of a Southern Refugee During the War, by a Lady of Virginia. New York: E.J. Hale \& Son, 1867. Reprint, Lincoln, NE: The University of Nebraska Press, 1995.

Northup, Solomon. Twelve Years a Slave. Auburn, NY: Derby and Miller, 1853. Reprint, Mineola, NY: Dover Publications, Inc., 1970. Reprint, 2000.

Pember, Phoebe. A Southern Woman's Story: Life in Confederate Richmond, including unpublished letters written from the Chimborazo Hospital. G.W. Carleton \& Company, 1879. Reprint, ed. Bell Irvin Wiley, 1959.

Pember, Phoebe Yates. A Southern Woman's Story. G.W. Carleton \& Company, 1879. Reprint, ed. George Rable. Columbia, SC: University of South Carolina Press, 2002.

Pickett, LaSalle Corbell (Mrs. Gen. George E. Pickett). Across My Path: Memories of People I Have Known. New York: Brentano's, 1916.

Pickett, LaSalle Corbell (Mrs. Gen. George E. Pickett). What Happened to Me. New York: Brentano's, 1917.

Prince, Mary. The History of Mary Prince, a West Indian Slave. London: F. Westley and A.H. Davis, 1831; in ed. Henry Louis Gates, Jr., Six Women's Slave Narratives, The Schomburg Library of Nineteenth-Century Black Women Writers. New York: Oxford University Press, 1988.

Pryor, Mrs. Roger A. Reminiscences of Peace and War. New York: The MacMillan Company, 1904.

Putnam, Sallie Brock. Richmond During the War: Four Years of Personal Observations. Lincoln, NE: University of Nebraska Press, 1876. Reprint, 1996.

Ruan, Mrs. C.F. A Brief Story of the Jackson-Feild Episcopal Home in the Diocese of Southern Virginia, Told by a Worker. Women's Auxiliary Diocese of Southern Virginia, n.d. (post-1935).

"Santa Claus in the Confederacy." Illustrated Southern News (no date).

Smith, J.P. (No title). Southern Historical Society Papers (1920). 
Sterling, Mrs. B.B. (No title). In The Lookout: A Journal of Southern Society I, No. 12 (January 16, 1909).

Sullivan, Walter. The War the Women Lived. Nashville: J.S. Sanders, compiled 1995.

The Stranger's Guide and Official Directory for the City of Richmond.

Showing the Location of the Public Buildings and Offices of the Confederate, State and City Governments, Residences of the Principal Officers, etc. Richmond, VA: Geo. P. Evans, Printers, 1863.

Virginia Conference of Orphanages: Report of a Study of the Methodist Orphanage. Richmond, VA: Child Welfare League of America, Inc., 1926.

Walker, Georgiana Gholson. The Private Journal of Georgiana Gholson Walker, 18621865, with selections from the post-war years, 1865-1876. Confederate Centennial Studies \#25. Ed. Dwight Franklin Henderson, 1963. Tuscaloosa, AL: Confederate Publishing Company, Inc., 1963.

Waugh, Charles G. \& Martin H. Greenberg, eds. The Women's War in the South: Recollections and Reflections of the American Civil War. Nashville, TN: Cumberland House Publishing, Inc., 1999.

Wilson, Augusta Jane Evans. A Southern Woman of Letters: The Correspondence of Augusta Jane Evans Wilson. Ed. Rebecca Anne Sexton. Columbia, SC: The University of South Carolina Press, 2002.

Wright, Mrs. Giraud. A Southern Girl in '61: The Wartime Memories of a Confederate Senator's Daughter. New York: Doubleday, Page \& Co., 1905.

Yates, B.C. "Christmas in the Confederacy.” Georgia Magazine (December 1961January 1962).

\section{$\underline{\text { Secondary Sources }}$}

Allgor, Catherine. Parlor Politics: In Which the Ladies of Washington Help Build a City and a Government. Charlottesville, VA: University Press of Virginia, 2000.

Beller, Susan Provost. Confederate Ladies of Richmond. Brookfield, CT: Twenty-First Century Books, 1999.

Bender, Thomas, ed. The Antislavery Debate: Capitalism and Abolitionism as a Problem in Historical Interpretation. Los Angeles: University of California Press, 1992. 
Bill, Alfred Hoyt. The Beleaguered City: Richmond, 1861-1865. Westport, CT: Greenwood Press, 1946. Reprint, 1980.

Blair, William. Virginia's Private War: Feeding Body and Soul in the Confederacy, 1861-1865. New York: Oxford University Press, 1998.

Bleser, Carol, editor. In Joy and in Sorrow: Women, Family and Marriage in the Victorian South, 1830-1900. New York: Oxford University Press, 1992.

Boylan, Anne M. The Origins of Women's Activism, 1797-1840. Chapel Hill: The University of North Carolina Press, 2002.

Breen, T.H. The Marketplace of Revolution. New York: Oxford University Press, 2004.

Brundage, Fitzhugh. The Southern Past: A Clash of Race and Memory. Cambridge: Harvard University Press, 2005.

Burke, Peter. What is Cultural History? 2 ${ }^{\text {nd }}$ ed. Malden, MA: Polity Press, 2004. Reprint, 2008.

Bynum, Victoria. Unruly Women: The Politics of Social and Sexual Control in the Old South. Chapel Hill: University of North Carolina Press, 1992.

Camp, Stephanie M.H. Closer to Freedom: Enslaved Women and Everyday Resistance in the Plantation South. Chapel Hill: The University of North Carolina Press, 2004.

Campbell, Jr., Edward D.C., Kim S. Rice, and Suzanne Lebsock. A Woman's War: Southern Women, Civil War, and the Confederate Legacy. Museum of the Confederacy Series. Charlottesville: University Press of Virginia, 1996.

Campbell, Jacqueline Glass. When Sherman Marched North From the Sea: Resistance on the Confederate Home Front. Chapel Hill: University of North Carolina Press, 2007.

Carmichael, Peter. Lee's Young Artillerist: William R.J. Pegram. Charlottesville, VA: The University Press of Virginia, 1995.

Caroli, Betty Boyd. First Ladies. New York: Oxford University Press, 1987.

Carter, Christine Jacobson. Southern Single Blessedness: Unmarried Women in the Urban South, 1800-1865. Chicago: University of Illinois Press, 2006.

Cash, Wilbur. The Mind of the South. New York: Alfred A. Knopf, Inc., 1941.

Cashin, Joan E. First Lady of the Confederacy: Varina Davis's Civil War. Cambridge, MA: The Belknap Press of Harvard University, 2006. 
Castigilia, Christopher. Interior States: Institutional Consciousness and the Inner Life of Democracy in the Antebellum United States. Durham, NC: Duke University Press, 2008.

Censer, Jane Turner. The Reconstruction of White Southern Womanhood, 1865-1895. Baton Rouge: Louisiana State University Press, 2003.

Clinton, Catherine. Public women and the Confederacy. Frank L. Klement Lectures: Alternative Views of the Sectional Conflict. James Marten, series editor. Milwaukee: Marquette University Press, 1999.

Clinton, Catherine. The Plantation Mistress: Woman's World in the Old South. New York: Pantheon Books, 1983.

Clinton, Catherine, ed. Half-Sisters of History: Southern Women and the American Past. Durham, NC: Duke University Press, 1994.

Clinton, Catherine, ed. Southern Families at War: Loyalty and Conflict in the Civil War South. Cambridge: Oxford University Press, 2000.

Clinton, Catherine and Nina Silber, eds. Divided Houses: Gender and the American Civil War. New York: Oxford University Press, 1992.

Dabney, Virginius. Richmond: The Story of a City. Charlottesville, VA: University Press of Virginia, 1990.

Davis, William C. Look Away!: A History of the Confederate States of America. New York: The Free Press, 2002.

Davis, William C. and James I. Robertson, Jr. Virginia At War, 1863. Lexington, KY: The University Press of Kentucky, 2009.

Dorsey, Bruce. Reforming Men and Women: Gender in the Antebellum City. Ithaca, NY: Cornell University Press, 2002.

Edwards, Laura. Scarlett Doesn't Live Here Anymore: Southern Women in the Civil War Era. Chicago: University of Illinois Press, 2004.

Enstad, Nan. Ladies of Labor, Girls of Adventure: Working Women, Popular Culture, and Labor Politics at the Turn of the Twentieth Century. New York: Columbia University Press, 1999.

Fahs, Alice. The Imagined Civil War: Popular Literature of the North \& South, 18611865. Chapel Hill: The University of North Carolina Press, 2001. 
Faulkner, Carol. Women's Radical Reconstruction: The Freedmen's Aid Movement. Philadelphia: University of Pennsylvania Press, 2004.

Faust, Drew Gilpin. Mothers of Invention: Women of the Slaveholding South in the American Civil War. Chapel Hill, NC: The University of North Carolina Press, 1996.

Fox-Genovese, Elizabeth. Within the Plantation Household: Black and White Women of the Old South. Series on Gender and American Culture. Chapel Hill: University of North Carolina Press, 1988.

Fergurson, Ernest B. Ashes of Glory: Richmond at War. New York: Vintage Books, 1996.

Gallagher, Gary. Causes Won, Lost and Forgotten: How Hollywood and Popular Art Shape What We Know About the Civil War. Chapel Hill, NC: The University of North Carolina Press, 2008.

Gallagher, Gary. The Confederate War: How Popular Will, Nationalism and Military Strategy Could Not Stave off Defeat. Cambridge, MA: Harvard University Press, 1997.

Gallman, J. Matthew. Mastering Wartime: A Social History of Philadelphia During the Civil War. New York: Cambridge University Press, 1990.

Gardner, Sarah E. Blood and Irony: Southern White Women's Narratives of the Civil War, 1861-1937. Chapel Hill: The University of North Carolina Press, 2004.

Genovese, Eugene. Roll, Jordan, Roll: The World the Slaves Made. New York: Vintage Books, 1976.

Genovese, Eugene. The Slaveholders' Dilemma: Freedom and Progress in Conservative Thought, 1820-1860. Columbia, SC: University of South Carolina Press, 1992.

Giesberg, Judith Ann. Civil War Sisterhood: The U.S. Sanitary Commission and Women's Politics in Transition. Boston: Northeastern University Press, 2000.

Ginzberg, Lori D. Women and the Work of Benevolence: Morality, Politics and Class in the $19^{\text {th }}$-Century United States. New Haven, CT: Yale University Press, 1990.

Gordon, Lesley J. and John C. Inscoe. Inside the Confederate Nation: Essays in Honor of Emory M. Thomas. Baton Rouge: Louisiana State University Press, 2005.

Green, Elna C. This Business of Relief: Confronting Poverty in a Southern City, 17401940. Athens: The University of Georgia Press, 2003.

Greenberg, Kenneth S. Honor and Slavery. Princeton: Princeton University Press, 1996. 
Glymph, Thavolia. Out of the House of Bondage: The Transformation of the Plantation Household. New York: Cambridge University Press, 2008.

Halttunen, Karen. Confidence Men and Painted Women: A Study of Middle-Class Culture in America, 1830-1870. New Haven, CT: Yale University Press, 1982.

Haskell, Thomas. "Capitalism and the Humanitarian Sensibility." In ed. Thomas Bender, The Antislavery Debate: Capitalism and Abolitionism as a Problem in Historical Interpretation. Berkeley, CA: University of California Press, 1992.

Higginbotham, Elizabeth. Righteous Discontent: The Women's Movement in the Black Baptist Church, 1880-1920. Cambridge: Harvard University Press, 1993.

Hobsbawm, Eric. The Age of Capitalism. New York: Vintage Books, 1975.

Isaac, Rhys. The Transformation of Virginia, 1740-1790. Chapel Hill: University of North Carolina Press, 1982. Reprint, 1999.

Jeffrey, Julie Roy. The Great Silent Army of Abolitionism: Ordinary Women in the Antislavery Movement. Chapel Hill: The University of North Carolina Press, 1998.

Janney, Carolina. Burying the Dead but Not the Past: Ladies' Memorial Associations and the Lost Cause. Chapel Hill: University of North Carolina Press, 2008.

Johnson, Walter. Soul by Soul: Life Inside the Antebellum Slave Market. Cambridge: Harvard University Press, 1999.

Johnston, Mary Tabb and Elizabeth Lipscomb Johnston. Amelia Gayle Gorgas: A Biography. Tuscaloosa, AL: University of Alabama Press, 1978.

Jones, Katharine M. Ladies of Richmond, Confederate Capital. New York: BobbsMerrill Company, Inc., 1962.

Kimball, Gregg D. American City, Southern Place: A Cultural History of Antebellum Richmond. Athens, GA: University of Georgia Press, 2000.

Lebsock, Suzanne. Free Women of Petersburg: Status and Culture in a Southern Town, 1784-1860. New York: W.W. Norton \& Company, 1985.

Levine, Lawrence. Highbrow, Lowbrow: The Emergence of Cultural Hierarchy in America. Cambridge: Harvard University Press, 1990.

Lockley, Timothy James. Welfare and Charity in the Antebellum South. Gainesville, FL: University of Florida Press, 2007. 
Lowry, Thomas P., M.D. Sexual Misbehavior in the Civil War: A Compendium. Xlibris Corporation, 2006.

Lowry, Thomas. The Stories the Soldiers Wouldn't Tell: Sex in the Civil War. Mechanicsburg, PA. Stackpole Books, 1994. Reprint, 2010.

Massey, Mary Elizabeth. Refugee Life in the Confederacy. Baton Rouge: Louisiana State University Press, 1964.

McCurry, Stephanie. Confederate Reckoning: Power and Politics in the Civil War South. Cambridge, MA: Harvard University Press, 2010.

McCurry, Stephanie. Masters of Small Worlds: Yeoman Households, Gender Relations, $\&$ the Political Culture of the Antebellum South Carolina Low Country. New York: Oxford University Press, 1995.

McPherson, James M. This Mighty Scourge: Perspectives on the American Civil War. New York: Oxford University Press, 2007.

McPherson, James M. and William J. Cooper, Jr., ed. Writing the Civil War: The Quest to Understand. Columbia, SC: The University of South Carolina Press, 1998.

Neely, Mark. Southern Rights. Charlottesville, VA: The University Press of Virginia, 1999.

Nissenbaum, Stephen. The Battle for Christmas: A Cultural History of America's Most Cherished Holiday. New York: Vintage Books, 1996.

Percy, William. Lanterns on the Levy: Recollections of a Planter's Son. New York: Alfred A. Knopf, Inc., 1945.

Phillips, Jason. Diehard Rebels: The Confederate Culture of Invincibility. Athens, GA: The University of Georgia Press, 2007.

Rable, George C. Civil Wars: Women and the Crisis of Southern Nationalism. Chicago: University of Illinois Press, 1989.

Roberts, Giselle. The Confederate Belle. Columbia, MO: University of Missouri Press, 2003.

Rockman, Seth. Scraping By: Wage Labor, Slavery and Survival in Early Baltimore. Baltimore, MD: The Johns Hopkins University Press, 2009.

Rose, Willie Lee. Rehearsal for Reconstruction: The Port Royal Experiment. New York: Oxford University Press, 1964. 
Rosenburg, Carroll Smith. Religion and the Rise of the American City: The New York City Mission Movement, 1812-1870. Ithaca, NY: Cornell University Press, 1971.

Ross, Ishbel. First Lady of the South: The Life of Mrs. Jefferson Davis. New York: Harper and Brothers, 1958.

Rowland, Eron. Varina Howell, Wife of Jefferson Davis, Vol. I. The MacMillan Company, 1927. Reprint, Gretna, LA: Firebird Press, 2000.

Ryan, Mary P. Civic Wars: Democracy and Public Life in the American City During the Nineteenth Century. Los Angeles: University of California Press, 1997.

Ryan, Susan M. The Grammar of Good Intentions: Race and the Antebellum Culture of Benevolence. Ithaca, NY: Cornell University Press, 2003.

Salerno, Beth A. Sister Societies: Women's Antislavery Organizations in Antebellum America. DeKalb, IL: Northern Illinois University Press, 2005.

Schmidt, Leigh Eric. Consumer Rites: The Buying \& Selling of American Holidays. Princeton, NJ: Princeton University Press, 1995.

Scott, Anne Firor. The Southern Lady: From Pedestal to Politics, 1830-1930. Charlottesville: University of Virginia Press, 1970. Reprint, 1995.

Shackelford, George Greene. George Wythe Randolph and the Confederate Elite. Athens, GA: University of Georgia Press, 1988.

Silber, Nina. Daughters of the Union: Northern Women Fight the Civil War. Cambridge: Harvard University Press, 2005.

Silber, Nina. Gender \& the Sectional Conflict. Chapel Hill, NC: The University of North Carolina Press, 2008.

Simkins, Francis Butler and James Welch Patton. The Women of the Confederacy. Richmond: Garrett and Massie, Incorporated, 1936.

Southern Churchman 111, No. 45 (1945).

Southern Partisan 9, No. 2 (1989).

Stanard, Mary Newton. Richmond: Its People and Its Story. Philadelphia: JB Lippincott Co., 1923. Virginia Historical Society, Richmond, VA.

Stansell, Christine. City of Women: Sex and Class in New York, 1789-1860. New York: Alfred A. Knopf, 1986. 
Stowe, Steven M. Intimacy and Power in the Old South: Ritual in the Lives of the Planters. Baltimore: Johns Hopkins University Press, 1987.

Sullivan, Walter, ed. The War the Women Lived: Female Voices from the Confederate South. Nashville: J.S. Sanders \& Company, 1995.

Takagi, Midori. “Rearing Wolves to Our Destruction”: Slavery in Richmond, Virginia, 1782-1865. Charlottesville: University Press of Virginia, 1999.

Tennant, Eugenia L. American Christmases: From the Puritans to the Victorians. Hicksville, NY: Exposition Press, 1975.

Thomas, Emory M. The Confederate State of Richmond: A Biography of the Capital. University of Texas Press, 1971. Reprint, Baton Rouge: Louisiana State University Press, 1998.

Towers, Frank. The Urban South and the Coming of the Civil War. Charlottesville: University Press of Virginia, 2004.

Ural, Susannah J. Don't Hurry Me Down to Hades: The Civil War in the Words of Those Who Lived It. New York: Osprey Publishing, 2013.

Varon, Elizabeth. White Women and Politics in Antebellum Virginia. Chapel Hill: The University of North Carolina Press, 1998.

Varon, Elizabeth. We Mean to be Counted: White Women and Politics in Antebellum Virginia. Chapel Hill: University of North Carolina Press, 1998.

Wakelyn, Jon L. Confederates Against the Confederacy: Essays on Leadership and Loyalty. Westport, CT: Praeger Publishers, 2002.

Walters, Ronald G. The Antislavery Appeal: American Abolitionism After 1830. Baltimore: The Johns Hopkins University Press, 1976.

Waugh, Joan C. Surviving the Confederacy: Rebellion, Ruin and Recovery-Roger and Sara Pryor During the Civil War. New York: Harcourt Company, 2002.

Waugh, Joan C. and Gary Gallagher, eds. Wars Within a War: Controversy and Conflict Over the American Civil War. Chapel Hill, NC: The University of North Carolina Press, 2009.

Weddell, Elizabeth Wright. St. Paul's Church, Richmond, Virginia: Its Historic Years and Memorials. 2 vols; vol. 1. Richmond: The William Byrd Press, Inc., 1931.

Wheeler, Roy, ed. Historic Virginia. Charlottesville, VA: The University Press of Virginia, 1948. 
Whites, LeeAnn and Alecia P. Long. Occupied Women: Gender, Military Occupation and the American Civil War. Baton Rouge: Louisiana State University, 2009.

Wiley, Bell Irvin. Confederate Women. New York: Barnes \& Noble Press, 1975. Reprint, 1994.

Woodward, C. Vann. The Burden of Southern History. Baton Rouge: Louisiana State University Press, 1960.

Wyatt-Brown, Bertram. Honor and Violence in the Old South. New York: Oxford University Press, 1986.

Yellin, Jean Fagan and John C. Van Horne, eds. The Abolitionist Sisterhood: Women's Political Culture in Antebellum America. Ithaca, NY: Cornell University Press, 1994.

\section{Articles}

Banner, Lois W. "Religious Benevolence as Social Control: A Critique of an Interpretation." Journal of American History 60. [June, 1973]: 23-41.

Blanton, Suella Clopton. "In Praise of Mint Juleps" Regarding The Honorable John B. Clopton and His Wife Maria Gaitskill Foster," in The Clopton Chronicles. Clopton Family Genealogical Society. $<$ http://homepages.rootsweb.ancestry.com/ clopton/mint.htm $>$ Accessed 27 July, 2004.

Davis, Susan G. “'Making Night Hideous': Christmas Revelry and Public Order in Nineteenth-Century Philadelphia.” American Quarterly 34, no. 2. [Summer, 1982].

Faust, Drew Gilpin. "Altars of Sacrifice: Confederate Women and the Narratives of War." The Journal of American History [March, 1990]: 1200-1228.

Genovese, Eugene. "Yeomen Farmers in a Slaveholders' Democracy." Agricultural History 49, no. 2. [April, 1975]: 331-342.

Gill, Harold B., Jr. "Christmas Trees, the Confederacy and Colonial Williamsburg." Colonial Williamsburg. [Christmas 2005].

Gowen, Annie. "2,800 Prom Gowns From a Single Thread: New Orleans Students Salute Beltsville Teen Who Restored Their Hope." Washington Post. [May 12, 2006].

Griffin, Clifford S. "Religious Benevolence as Social Control, 1815-1860." The Mississippi Valley Historical Review 44. [Dec., 1957]: 423-444.

Lears, T.J. Jackson. "The Concept of Cultural Hegemony: Problems and Possibilities." 
The American Historical Review, 90, no 3. [June, 1985]: 567-593.

Link, William A. "The Jordan Hatcher Case: Politics and a 'Spirit of Insubordination' in Antebellum Virginia." Journal of Southern History, 64. [1998]: 615-648.

Johnson, Walter. "A Nettlesome Classic Turns Twenty-Five." Common-Place 1, no. 4. [July, 2001]. <http://www.common-place.org/vol-01/no-04/reviews/johnson.shtml >

McCurry. Stephanie. "The Two Faces of Republicanism: Gender and Proslavery Politics in Antebellum South Carolina." Journal of American History. [March, 1992]: $1245-1264$.

“The Hungry Holiday of 1865.” Style Weekly, December 23, 1991.

Virginia Magazine of History and Biography, 116, no 4. [2008]. Richmond, VA: Virginia Historical Society, 2008.

Wickberg, Daniel. "What is the History of Sensibilities?" American Historical Review. [June, 2007]: 661-684.

Yates, B.C. "Christmas in the Confederacy.” Georgia Magazine. [December 1961January 1962].

\section{Dissertations}

Barber, Edna Susan. "Sisters of the Capital: White Women in Richmond, Virginia, 1860-1880." University of Maryland, 1997.

Latimore, Carey H, IV. "Always a Minority: Richmond Area Free Blacks in the Civil War Era.” Emory University, 2005.

Minton, Amy Karen Rider. "The Rise of Respectability: Southerners and Social Relations in Richmond, Virginia, 1845-1875." University of Virginia, 2006. 